Historic, Archive Document

Do not assume content reflects current scientific knowledge, policies, or practices. 



\section{7}

\section{9}

\section{Cafalogue of}

Seeds. Plants. Bulbs

\section{Poultry Supplies}

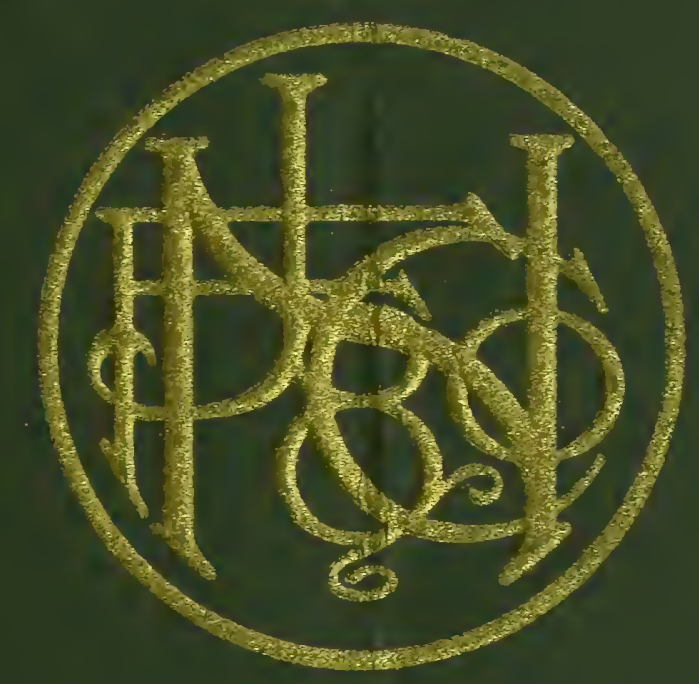

\section{F, NOLL \& CO. SEEDSMEN}

115 Mulberry Sires? NEYARR, N. 1. 


\section{Cultural Instructions for Vegetable Seeds}

ASPARAGUS SHPD. One ounce will sow" 75 feet of drlll. Sow during April and May. It takes from four to five years to produce a crop of Asparagus from seed.

ASPARAGUS RoOrs. Set out in April in soil well drained. Set the plants from 12 to 18 inches apart in the row and keep the rows from three to five feet apart. Use precaution to spread the roots well when planting. Dig trenches about 15 inches wide and about 18 inches deep. Put in about six inches of manure and cover with two inches of soil, so the roots do not come in contact with the manure. Keep the bed free from with a cultivator.

BEATS-DWARY VARIETIES. One quart will sow 100 feet of drill; one bus. to the acre. Sow beans from the first of May until September. Plant in rows from 18 to 24 inches apart. Sow the seed two inches deep and two inche

BFAגS-POTE VAZIrTIEs. One quart sows 125 hills; 10 to 15 quarts per acre. Sow in hills three feet apart five or six beans to a hill, two inches deep. Use wellrotted manure. Use poles about eight feet long. Pole Beans succeed best in a sandy loam. Sow in May for an early crop, June for late crop.

ВЕम2. Two ounces to 100 feet of drill. Sow in drills twelve inches apart and two inches deep. They do best three or four leaves, transplant five or six inches apart.

BRUS8\%.s SPROUms. Sow in drills in April or May and transplant about two feet apart. Cultivate same as

CABBAGม. One ounce will produce 2,000 plants. For early Cabbage sow in February. Transplant into boxes three inches deep and two inches apart when they attain their fourth leaf. Plant in the open by the first of April. For late Cabba

CAzizors. One ounce will sow 100 feet of drill; three to four pounds per acre. For an early crop sow as soon as the ground can be worked outdoors. Sow in drills about 18 inches apart and thin them out about four inches between the plants. Carrots, do best in sandy loam well manured.

CAUIIFIOWFR. One ounce produces 1,000 plants. Treat the same as Cabbage. Plant from 16 to 20 inches apart and in rows from 20 to 30 inches apart.

CrIfRY. One ounce will produce about 2,500 plants. Sow the seed outside as soon as the ground can be
cultivated. Sow in drills about two inches deep, and firm the seed in the soil. When ready to transplant, place six inches apart in the rows and keep the rows essential to the proper development of Celery. Start to bank the Celery about September for the purpose of b]eaching; use a spade to do so.

CrIమRIAC. Sow the same as Celery. When ready to transplant place it six inches apart in the rows and keep the rows about one and a half feet apart. For Winter use cover over with leaves or straw.

CFrRVIr. Sow the seed from early Spring to the latter part of August. Sow in rows 10 or 12 inches apart and thin out to five inches apart in the row.

COR2 SAIAD. SOW in drills one foot apart in early Spring. It will be ready for use in about six weeks. Sow in september for an early Spring crop and cover to protect it from frost.

CORx, 8Wrar OR SUGAR. One quart will sow 150 hills Eight quarts to the acre in hills. Sow about the middle of May in rows about four feet apart and eight to ten inches apart in the row. If sown in hills, keep the hills three to four feet apart each way. Succesevery two or three weeks.

CUCUMBER. One ounce plants 50 hills. Cucumber can be sown from May 15 to July 15 . Have the soil well ten seeds to a hill. When the plants attain their third or fourth leaf, thin out to four plants to each hill. Cucumbers are subject to insects and are usually at tacked as soon as the plants appear. Great care should be taken not to let the insects get'a lead as they, destroy the crop in a vory short time.

DANDEIION. Sow in early Spring. Keep the rows 15 inches apart and when the plants are well started.thin out to 10 inches between the plants.

IGC PIANT, One ounce will produce from 500 to 700 plants. Sow the seed in hotbeds during March and April, and when about two inches high plant in 3 -inch pots. 'Set out in June about three feet apart in soll well manured.
अ10IV 2. Sow about the middle of April for an early supply. For main crop sow in June and July and transplant one foot apart each way. When of sufficient size tie with raffia to bleach.

XOII RABI. One ounce produces about 3,000'plants. Sow the seed same time as Cabbage and when about four inches high, transplant about 10 inches apart.

TAIE. One ounce will sow 100 feet of drill. For an early Spring crop sow about August and transplant two feet apart. For a Fall crop sow in June and transplant.

Ixम2. One ounce to 100 feet of drill. Sow in the spring as soon as the ground can be cultivated. When about six inches high transplant in rows about eight inches apart.

IसTHUCE. One ounce will produce about 2,000 plants. Lettuce is generally sown about March $1^{2}$ in hotbeds and when about three inches tall, transplanted into boxes about three inches deep and hardened off, after which they are set in the open ground as soon as the ground can be cultivated. For late sowings, sow from April to August. Keep the soil well cultivated.

MrIOX, WATra. One ounce to 25 hills. Watermelon requires a good sandy loam. Sow about May, putting eight seeds to a hill, keeping the hills eight feet apart each way. When the plants attain their fourth leaf thin out to two or three plants to each hill.

MrIOK; MUsk. One ounce will sow 50 hills. Cultivate same as Watermelon, keeping the hills five feet apart each way.

OKra. One ounce produces about 250 plants. Sow middle of May in drills about two inches deep. Thin out from two to three inches apart in the row.

Oxtox. One ounce will sow 75 feet of drill. Onions delight in a heavy soil. Have the ground heavily manured and finely cultivated before sowing. Sow in drills about 15 inches apart. Weeding is very essential to raising onions and precautions should be taken not to let the weeds gain any headway. When about five inches tall thin out to two inches between the plants.

PARsire. One ounce will sow 150 feet of drill. Sow in drills about one and a half feet apart. When the plants are well advanced, thin out to six inches apart in the rows.

PARSI3\%. One ounce will sow 100 feet of drill. Sow early in Spring in drills about one foot apart and halfinch deep. The seed of parsley is slow to germinate, taking from three to six weeks.

Pzas. One quart sows 100 feet of drill. Early smooth varieties can be sown as soon as the frost is out of the ground. Sow in rows three feet apart and three inches deep. Wrinkled varieties can be sown as soon as the cold and wet weather has vanished. Sowings can be made up to the 15 th of August.

PrPPER. One ounce will produce 500 plants. Sow same time as Egg-Plant. When setting out keep the plants from two to three feet apart. Plant in soll well manured.

PUMLPIr. One ounce plants 25 hills. Sow about May in hills six feet apart. Have the soil heavily manured.

RADISF. One ounce will sow 100 feet of drill. Sow about March 15 in rich sandy loam. For early Radishes sow in a hotbed during February. Sowings can be made up to September.

RUIA BAGA. Sow from May 15 to June 15. Sow in rows two feet apart and thin out to 12 inches apart in the rows. Use well-rotted manure when preparing the soil.

SAISIrY. One ounce to 50 feet of drill. Sow in rows 18 inches apart and about one and one-half inches deep. Thin out to six inches apart in the rows.

soras.r. Sow in rows about 12 inches apart. Sow thinly BPITACE. One ounce to 100 feet of drill. Sow in drills 15 inches apart during April and continue up to September. Sow in good soil.

SQUASF. One ounce to 25 hills. Same culture as for Pumplins.

SWISS-CIAARD. Sow in April or May in drills about 15 inches apart and thin out to 10 inches apart in the rows.

TOMamo. One ounce will produce 1,000 plants. Sow during. March in hotbeds. When/plants are three inches high transplant in boxes three inches deep. Plants can be set outdoors about May 15 . Rich soil is not required for Tomatoes.

TURIIE. One ounce will sow 100 feet of drill. For main crop sow in August. Turnips can be sown broad. cast or in drills. For early varieties sow in April in drills about 12 inches apart and thin out to six inches apart in the drills. 


\section{INDEX}

The letters preceding the page number below indicate': "S" for Seeds; "p" for Plants; "B" for Bulbs; "R" for Roots

PAGE

Abutilon $\ldots \ldots \ldots \ldots \ldots$. . . . S 39

Achillea $\ldots \ldots \ldots \ldots \ldots \ldots$. . . . . 39

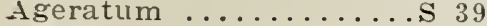

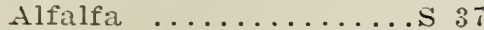

Alfalfa iroal ............. 69

Althea ............. 65

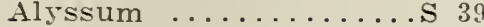

Amaranthus ........... 39

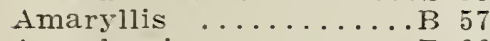

Ampelopsis ............ 66

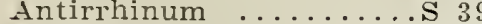

Aquilegia .......... 40. P 62

Aristolochia ........ 40, P 66

Articholie .............. 3

Asparagus...s \& $\mathrm{R} 3,34,40$

"Ornamental" ........s 40

Asters ............................ 40,41

Asters ............. 62

Balloon Vine ...........S 41

Balsam ................ 41,49

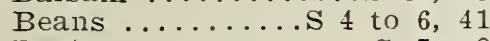
Beet .................. 7,8

" Mangel and Sugar...S 36

Begonia ..........S 42 , B 57

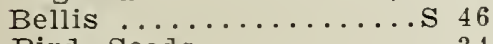

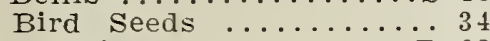

Bleeding Heart ......R 62

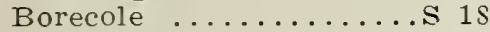

Borage ................................. 9

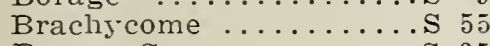

Broom Corn ............ 3 2

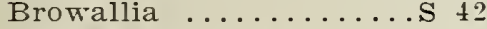

Brussels sprouts ........ 9

Bryonopsis ........... 42

Cabbage ............ 9, 10 Caladium, Fancy ........ B 57 "Esculentum ....... B 57

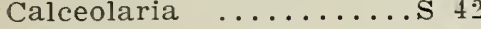
Calendula ............. 4 .

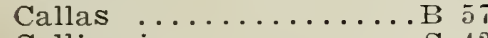

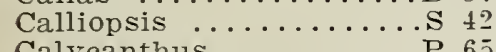
Calycanthus .........P 6 Campanula ........S 43, P 62 Canary Bird Tine......S 43

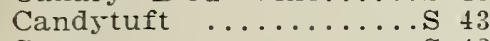

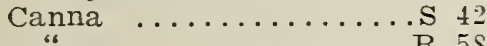
Canterbury Bells ........ 43 Carnation ............... 43 Carrot ..................... 11, 36 Castor Oil Plant $\mathrm{S} 35,43,53$ Cauliflower .......S 12, P 3

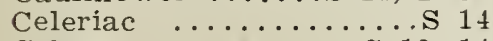

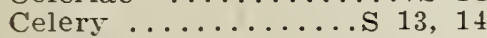
Celosia ................ 43

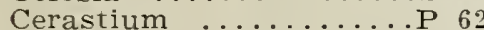
Centaurea .............................. 434

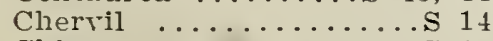
Chicory ............... 14 Chrysanthemum ..S $44, \mathrm{P} 62$ Cineraria ..................... 44 Cinnamon vine............ 66 Clematis ............. 44 , P 66

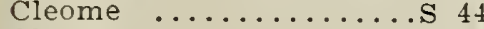

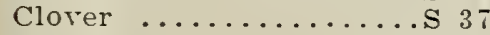

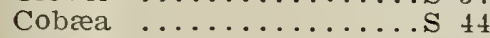

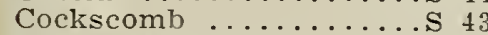
Coffea Arabica ........ 44

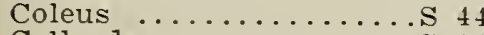
Collards $\ldots \ldots \ldots \ldots \ldots \ldots \ldots$. 14
Columbine .......S 40, P 62 Convolvulus ............. 45

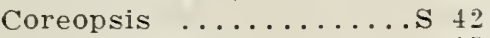

Corn, Sweet .......... 13 “ Ensilage .............. 35 Corn Salad .............. 12

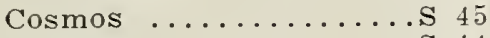

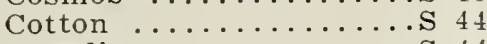

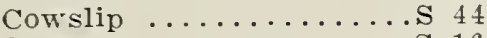

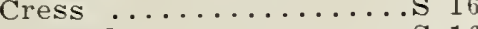

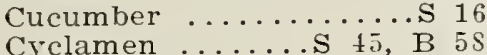

Cyclamen $\ldots \ldots \ldots . . .$.
Cyperus

Cypress Vine ..........S 45

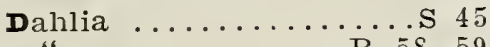
Daisies $\ldots \ldots \ldots \ldots \ldots$ R 58,59

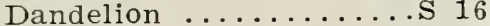

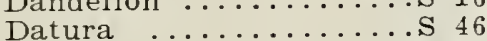
Delphinium ............ 46 Deutzia .............P 65 Dianthus .........S 46, P 64 Dielytra Spectabilis ...R 62

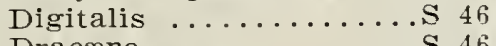

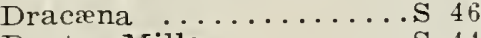
Dusty Miller ........... 44

Echinocystis .......... 46 Egg-Plant.........S 17, P 34

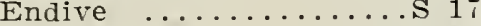

Eschscholtzia $\ldots . . . . . .547$ Euphorbia ................ 47

Fennel ................ 16

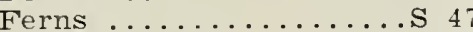

Fertilizers

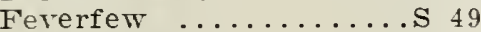

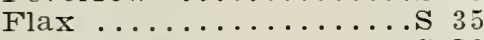
Forget-me-not ......... 50

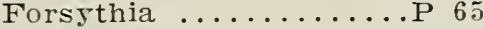
Foxglores ............. S 46

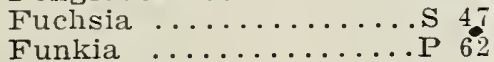

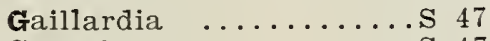

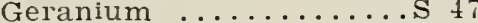
Gladiolus ........................ 60

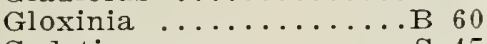

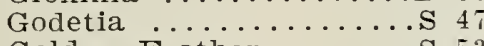

Golden Feather ......... 53

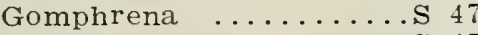

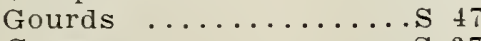

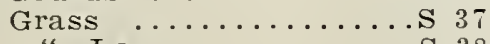
Gypsophila $\ldots \ldots \ldots \ldots \ldots \ldots$. ${ }^{2} 47$

Fardy Plants ........P 66 Shrubs … Helianthus .......... 5 j, R 62 Helichrysum ..........S 47

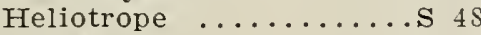
Herbs $\ldots \ldots \ldots \ldots \ldots \ldots$. . . 34 Hollyhock .................. 48 P 63 Honeysuckle $\ldots \ldots \ldots$. P 66 Hop, Japan ............ 48 Hop Vine ............ P 66 Horse Radish ..........R 34 Humulus ................ 4 , P 66 Hyacinth Bean ........S $4 S$ Hyacinthus $\ldots \ldots \ldots \ldots \ldots$. . . . . . 61
Hydrangea
PAGE

Ice Plant

S $4 S$

Implement

Insecticides

Ipomœa ........ $48, \mathrm{P} 66$

Iris $\ldots \ldots \ldots \ldots \ldots \ldots \ldots$ P 63

Ismene Calathina ....... 61

Japan Hop

Japonicum

rale

Kenilworth Iv

Kohl Rabi

Lantana

Larkspur

Lathyrus

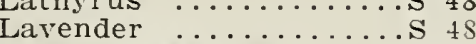

Lawn Grass Seed....... 38

Lawn Mowers $\ldots \ldots \ldots .68$

Leek $\ldots \ldots \ldots \ldots \ldots \ldots$ s 18
Lettuce $18 \ldots \ldots \ldots \ldots$

Lettuce ........... 34

Lilac ........... 65

Lilies of the Valley..... R 63

Linum ............... 49

Lobelia $\ldots \ldots \ldots \ldots \ldots . . . .5$

Love-in-a-Mist ......... 51

Madeira Vine .......... 66

Magnolia ........... 65

Mrangel Turzel ........... 36

Maples, Japanese .....P 65

Marigold ................ 49

Marvel of Peru .........S 49

Matricaria ............ 49

Maurandia ............. 49

MTelon, MIusk ............. 20

Melon, Tater ........... 20

Mesembryanthemum ..... S 49

Mignonette ......S 49, P 61

Millet ............... 35

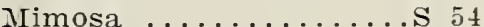

Mimulus ........... 50

Momordica ........... 49

Iontbretia ........... 61

IIoon Flower.....S 4S, P 66

Morning Glory ..........s 45

Mushroom spawn ....... 21

Musk Plant ............. 50

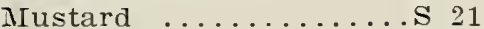

Myosotis $\ldots \ldots \ldots \ldots \ldots$. 50

Nasturtium .......S 21, 50

Nicotíana ................ 51

Nigella ................ 51

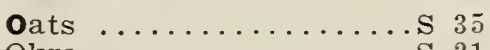

Okra $\ldots \ldots \ldots \ldots \ldots \ldots$ S 21

Onion $\operatorname{set} \ldots_{\ldots \ldots} \ldots \ldots \ldots \ldots$

Oxalis ...........

Pæonia ...........R 64

Pansy ................. 51

Papaver .....S 52, 53, P 64

Parsley .............. 23

Parsnip .......... 23, 36

Passion Flower ............ 51

Peas $\ldots \ldots \ldots \ldots \ldots$. 24,25

Peas for fodder, etc....s 35

Pentstemon .............. 51

Pepper ............ 23, P 34

Petunia $\ldots \ldots \ldots \ldots . .$. . 5 . 51

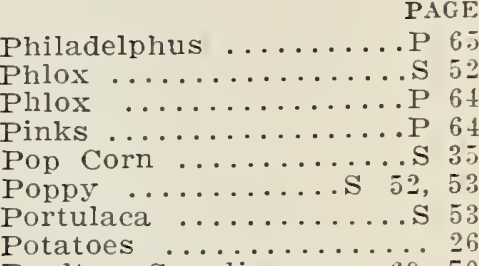

Potatoes supplies.......... 70

Primula (Primroses) ...S 53

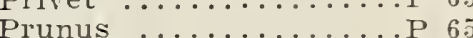

Pumpkin ............. 26

Pyrethrum ............. 5

Radish $\ldots \ldots \ldots \ldots$ s 26,27

Rape …..........

Rhubarb....R 27,34, S 27

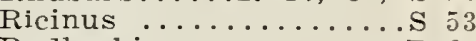

Rudbeckia ........... 64

Ruta Baga ........ 33, 36

Rye .................. 3 5

Salpiglossis $\ldots \ldots \ldots \ldots . . . . .5$

Salsify $\ldots \ldots \ldots \ldots \ldots . . . . .628$

Salvia $\ldots \ldots \ldots \ldots \ldots \ldots \ldots$. 5 s 5

Scabiosa ............. 5

Schizanthus ............ 5

Sea Kale ............. S 29

Sensitive Plant ............

Shallots ............ 2

S 5

Smilax ...............

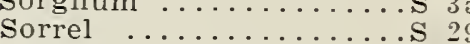

Spinach .............. 29

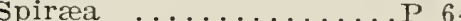

Squash $\ldots \ldots \ldots \ldots \ldots$. 28

Stocks ........... 55

...S 35,5

weet Pea ............ S 5

Sweet Rocket ...........

Sweet Sultan ..........

Sweet Tilliam ............

Syringa ........... 65

Tarragon ..........R 3

Tecoma Velutina...........

Thunbergia $. . \ldots \ldots \ldots . .6$ s 5 5

Tigridia ............... 60

Tobacco ................ 5

Tools, Implements, $6 \dot{S}, 71,72$

Tomato ...S 30, 31, 32, $\mathrm{P} 34$

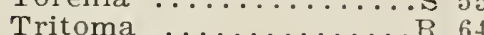

Tuberoses ........... 61

Turnip .............. 33,36

Verbena ............. 5

Vetch $\ldots \ldots \ldots \ldots \ldots$. 35

Viburnum ............ 6

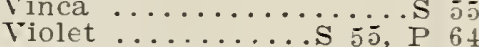

Virginiä stock ........S 55

wallflower .....S 56, P 64 Thater Lilies ............ 6 ? Theat $\ldots \ldots \ldots \ldots \ldots \ldots$. 3 Wild Flower Garden.....s 56 Tild Rice ...............

Yucca ......... 5 5, P 64

zinnias ............. 56 


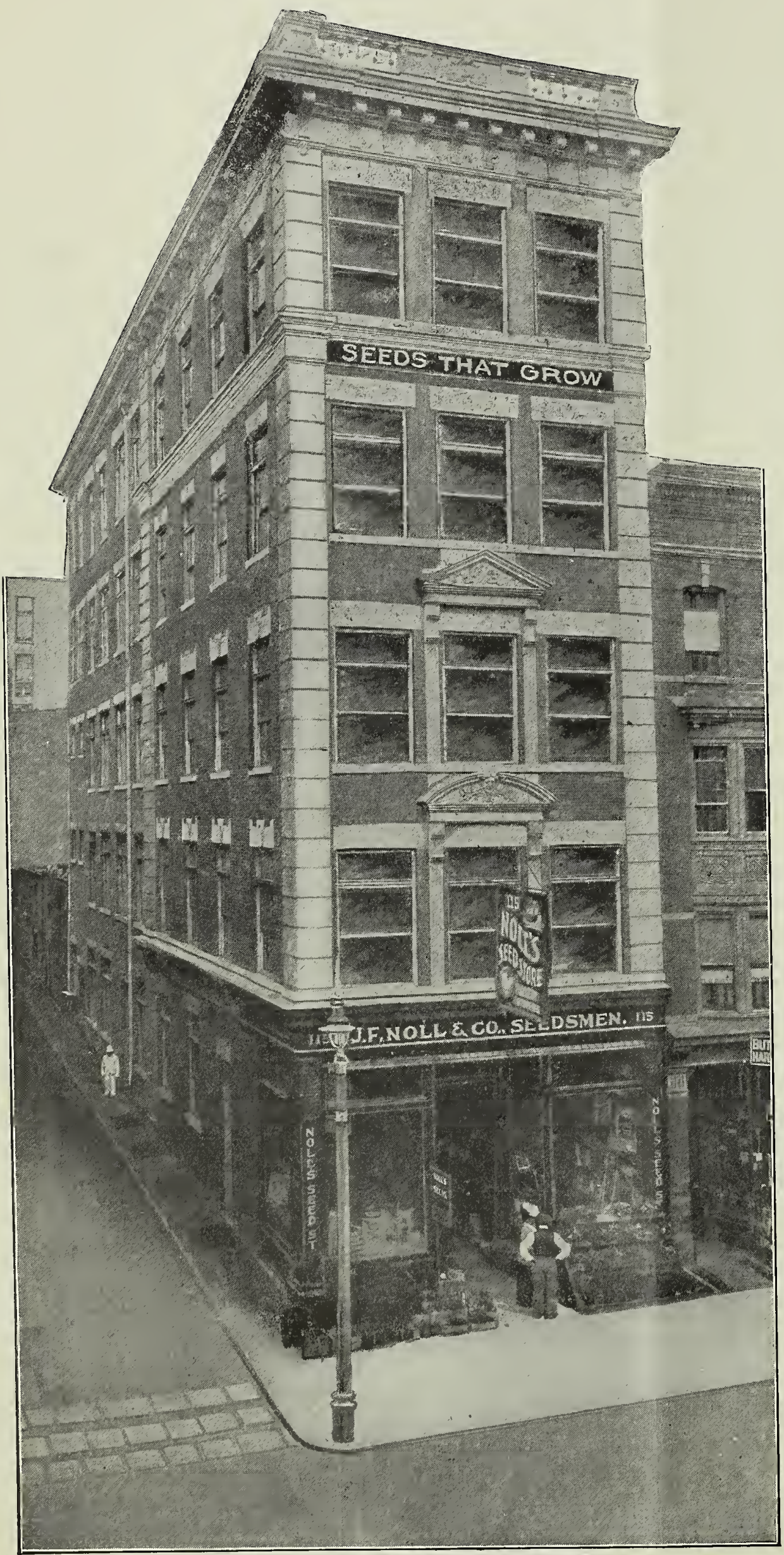

NOLL'S BUILDING, STORE AND WAREHOUSE

\section{Noll's Seeds, Etc. are procurable only from us direct}

\section{How to Order, Etc.}

Order Farly. It will greatly fasilitate shipments if orders are sent in early. We aim to send off all orders the same or next day after receipt, but during the rush season this is impossible-hence the advisability of ordering early.

Iorwarding. We deliver, postage paid, to any post office in the United States, Vegetable and Flower Seeds in packets, ounces and pounds, at catalogue prices, except where otherwise noted; but it will be much cheaper to the purchaser if goods are ordered to be sent by Express or Freight at their expense, when desired in any quantity.

Remittances should be made either in the form of an Express Money Order, P. O. Money Order, Bank Draft or Registered Ietter.

Goods wanted C. O. D. must have 20 per cent. of the amount accompany the order.

Give full Shipping Instructions on each and every order you send.

Orders from unknown correspondents, without remittance, should be accompanied by reference to save delay.

By writing out your order on the Order Sheet which accompanies this Catalogue, you will greatly facilitate our work. Extra order sheets mailed on application.

Be sure to sign your name and give your address. Many orders reach us lacking one or both; customers when writing about unsigned orders will aid us in identification by mentioning some of the articles ordered.

Every order is filled immediately on arrival, or is acknowledged, if, under rare circumstances, its shipment is likely to be delayed for a day or two. If goods or acknowledgment of order is not received by the customer after a reasonable lapse of time, it may be assumed that the order has miscarried, or that the name or address was omitted from the order. We will, when notified of such a case, use our best efforts to trace it promptly.

We make no charge for cartage or delivery of goods to any railroad station, steamship line or express office in Newark.

Cloth Bags only we charge for, and these at cost.

J. $\mathbf{3}$. NOII \& CO. give no warranty, express J. 1. wounction, quality, productiveor implied, as to descrater of any Seeds, Bulbs ness, or any other matter of any seeds, nulbs or Plants they send out, and they will not be in any way responsible for the crop. If the purin any woos not accept the goods on these terms, they are to be returned at once. 


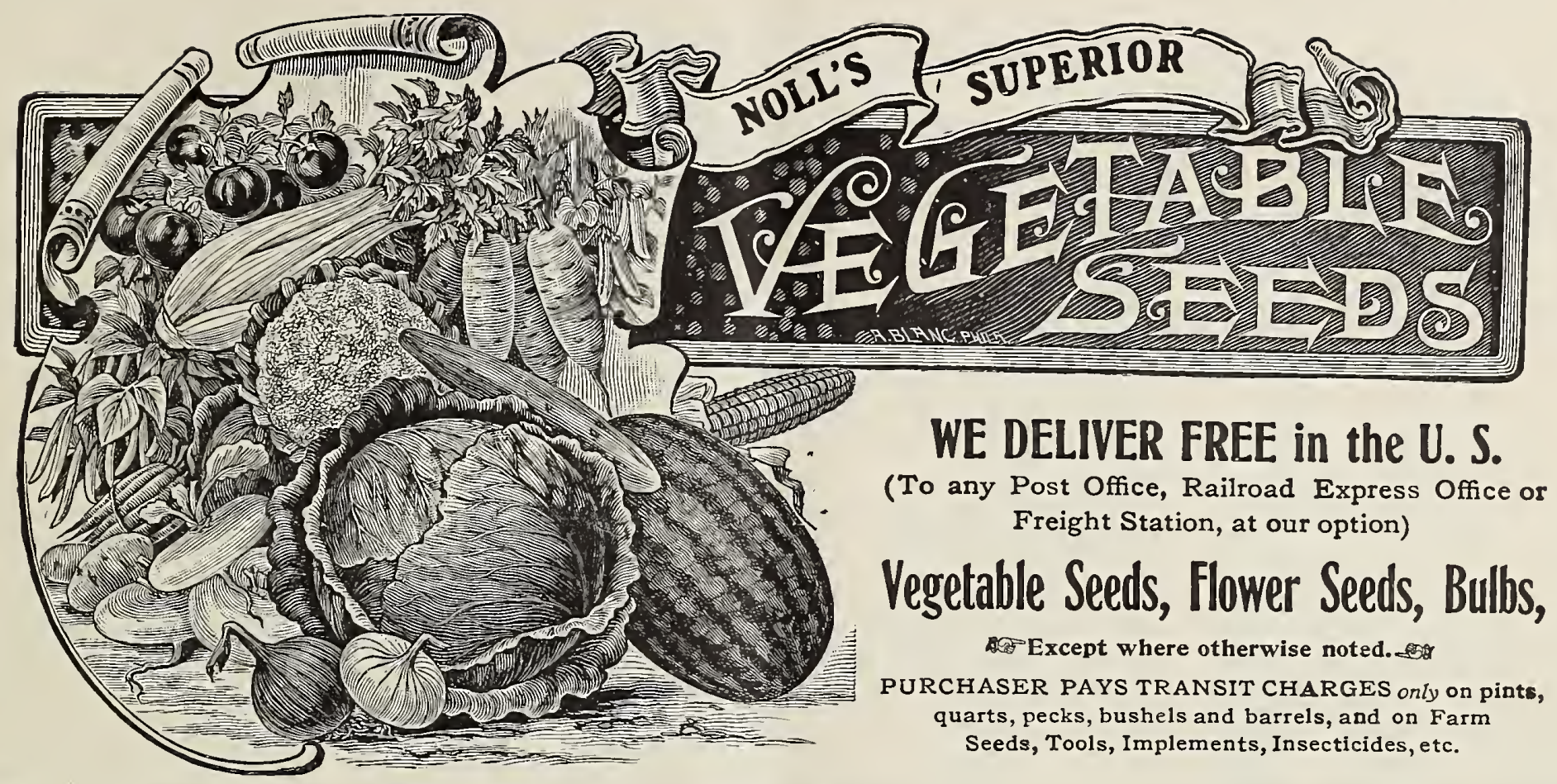

\section{ARTICHOKE}

Jerusalem Tubers. (Buyer paying transit.) Qt. 25c., pk. $\$ 1.25$, bush. $\$ 4.00$.

Pkt. Oz. $1 / 4 \mathrm{lb}$.

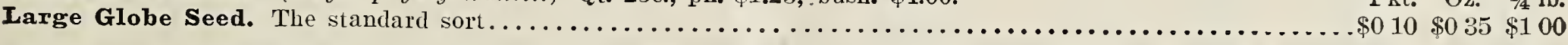

\section{EARLY FRENCH GIANT ASPARAGUS}

\section{A GREAT MARKET AND EXHIBITION VARIETY}

This new sort is a great improvement on the popular Palmetto or French Argenteuil Asparagus, which was first brought to this country by Mr. John Nix, the largest asparagus grower of South Carolina. The roots were imported from Mr. Louis Lérault de Argenteuil, of France, and have proven this new asparagus to be not only 10 days earlier than Palmetto, but of larger size

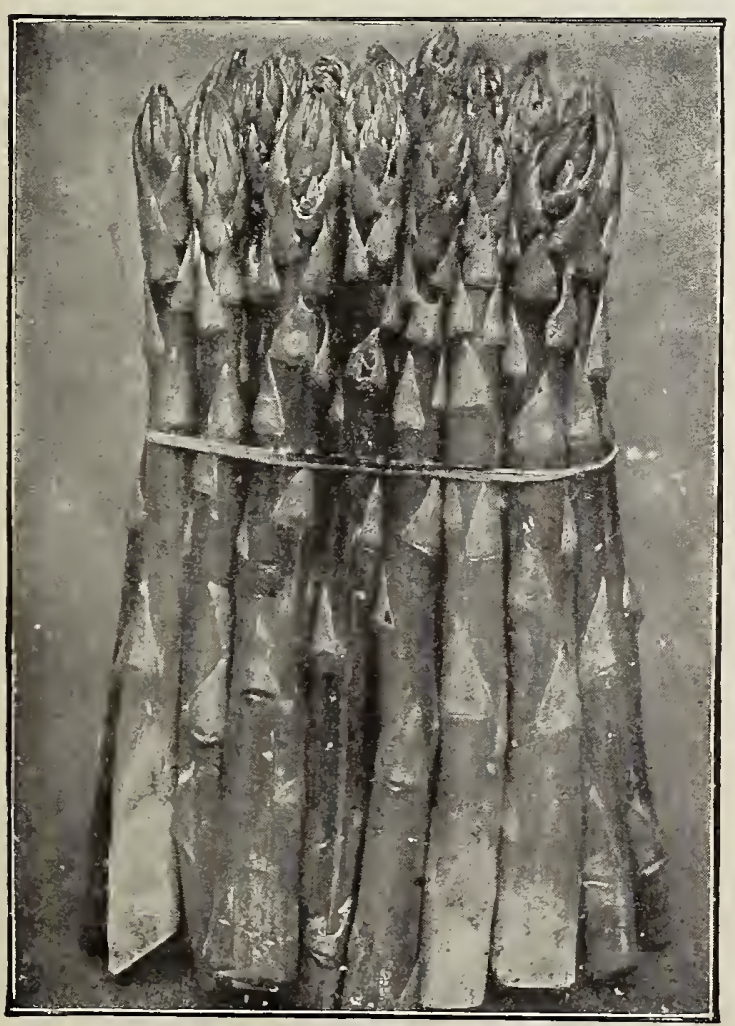

EARLY FRENCh GIANT ASPARAGUS and superior in flavor and color. In New York market it sold for $\$ 5.00$ per dozen, while other varieties only brought $\$ 1.50$ to $\$ 2.00$ per dozen. It is by far the most promising asparagus, as a money-maker, that can be grown. Our seed and roots are from the original importation that has attracted so much attention and sold so high in New York. Prices of seed: Pkt. 5c., oz. $15 c ., 1 / 4$ 1b. 35c., 1b. $\$ 1.25$. Two-year-old roots, $\$ 1.50$ per $100, \$ 8.00$ per 1000, by freight or express. (500 roots at 1000 rate.)

\section{ASPARAGUS SEEDS}

One ounce to 60 feet of drill.

Barr's Philadelphia Mammoth. One of the largest Pkt. Oz. 1/1 lb. Lb. and most productive..................... \$0 $05 \$ 010 \$ 020 \$ 060$

Colossal. A standard variety; fine quality....... 0.5 10 15 50

Columbian Mammoth White. I variety produc-

ing large white shoots....................... $0510 \quad 20 \quad 60$

Palmetto. Early, prolific and of uniformly large size. $\begin{array}{lllll}0.5 & 10 & 15 & 50\end{array}$

\section{ASPARAGUS ROOTS}

(For free delivery in U. S. add to prices, 3je. per 100 to two-year-old roots; ise. per 100 to three-ycar-old.)

Barr's Philadelphia Mammoth. Tro-year-old roots (buye: paying transit), $\$ 1.50$ per $100 ; \$ \$ .00$ per 1000 .

Colossal. Trio-year-old roots (buyer paying transit), $\$ 1.50$ per $100 ; \$ \$ .00$ per 1000.

Columbian Mammoth White. Two-year-old roots (buyer paying transit), $\$ 1.50$ per $100 ; \$ 8.00$ per 1000 .

Palmetto. Two-year-old roots. $\$ 1.50$ per $100 ; \$ \$ .00$ per 1000 . 


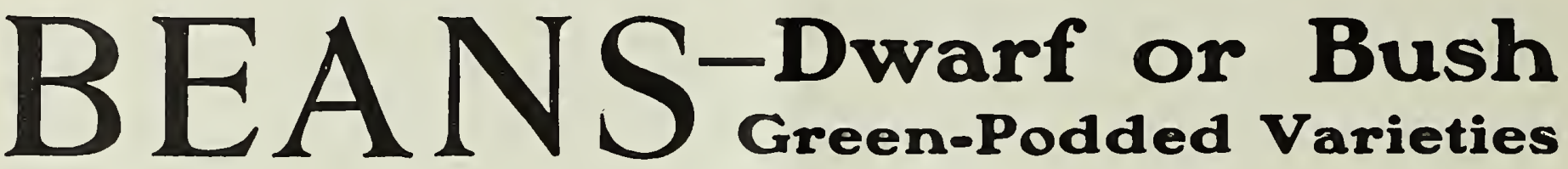

One quart to too feet of drill

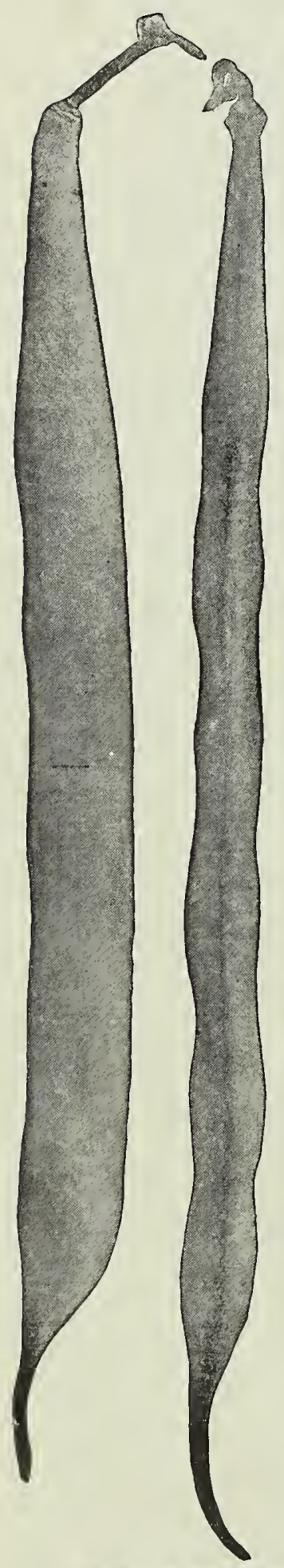

KING OF THE RARLY BEAN

\section{NOLL'S SELECTED STRAIN King of the Early Round Green Bean}

Positively the earliest and hardiest of all the green varieties. Earlier than the Red Valentine Bean.

This variety can be planted fully a week earlier than any other green bean, as the dry bean will stand considerable cold wet weather, while other varieties at the same time will rot in the ground. The main feature of this bean is its earliness. The pods usually being ready to pick at least five days ahead of Red Valentine, and are a beautiful green color, extra long, almost straight, round, thick, meaty, tender, and in flavor unsurpassed. A very valuable feature is that the first picking is a heavy one. The demand for this bean has been very much in excess of the supply, and as a money-maker we offer nothing in the seed line that has proved so advantageous to our gardeners as this particular item. Adapted for late as well as early planting, owing to the hardiness of the vine. which resists unfavorable weather and disease. $1 / 2$ pt. 10c., pt. 20c., qt. 30c., pk. $\$ 1.75$, bush. $\$ 6.50$.

Bountiful. Very early, entirely free from strings, fine crop- 1/2 Pt. Pt. Qt. Pk. Bu. per, flat pod; a desirable variety..................\$0 $10 \$ 020 \$ 030 \$ 150 \$ 500$

Black Valentine. Pods extremely long, round and straight; very attractive in appearance........................... $10 \quad 20 \quad 30 \quad 175 \quad 650$
Extra Early Red Valentine. Pods are round and fleshy; big yielder, fine quality.$\ldots \ldots \ldots \ldots \ldots \ldots \ldots \ldots \ldots \ldots$

French Lead Pencil. Round green-podded variety, extra

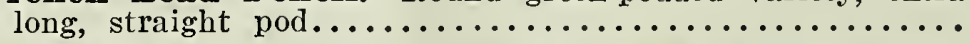

Longfellow. Very early, prolific, stringless and tender.....

Long Yellow Six Weeks. Very early and prolific; long,

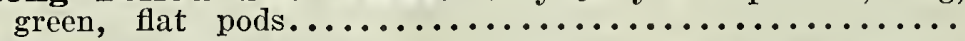

Newington Wonder. An entirely stringless green-podded

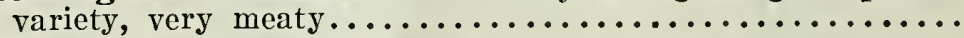

New Stringless Green Pod. A very quick grower, pro-

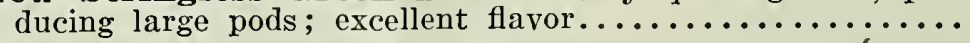

Refugee, or 1000 to 1. A popular medium late variety;

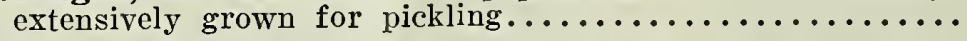

Refugee Extra Early. Similar to Refugee, or 1000 to 1, but two weeks earlier; enormously prolific..............

White Marrow. A popular shell bean; seeds white......

Boston Pea Bean. Very productive for baking; excel all other sorts $\ldots \ldots \ldots \ldots \ldots \ldots \ldots \ldots \ldots \ldots \ldots \ldots \ldots \ldots \ldots$

$\begin{array}{lllll}10 & 20 & 30 & 175 & 650 \\ 10 & 20 & 30 & 125 & 400 \\ 10 & 20 & 30 & 175 & 600 \\ 10 & 20 & 30 & 175 & 600 \\ 10 & 15 & 25 & 125 & 450 \\ 10 & 20 & 30 & 175 & 600 \\ 10 & 20 & 30 & 175 & 600 \\ 10 & 15 & 25 & 125 & 400 \\ 10 & 15 & 25 & 125 & 400 \\ 10 & 15 & 25 & 130 & 450 \\ 10 & 15 & 25 & 130 & 450\end{array}$

Beans, Peas and Corn we do not deliver free, but will do so if 10c. per qt. is added to the prices. 


\section{BEANS-Dwarf or Bush-Wax Podded or "Butter"}

\section{"Noll's Selected Strain" California Rust-Proof Flat Wax Bean}

Positively the earliest, hardiest and most productive flat pod Wax Bean ever offered.

It can be planted fully a week ahead of any other Wax Bean on account of its extreme hardiness, and will pick four to five days ahead of any other Wax variety planted at the same time. The vines are of a vigorous growth and yield enormous quantities of large, handsome flat pods. In the vicinity of Norfolk where thousands of bushels of these beans are planted annually it has proven to be the most satisfactory flat Wax variety. The seed should be planted not closer than four inches apart in the row. Market Gardeners should not fail to grow this valuable variety. $1 / 2$ pt. 10c., pt. 15c., qt. 25 c., pk. $\$ 1.25$, busk. $\$ 4.00$.

Black Wax, Improved. Very ${ }^{1 / 2}$ Pt. Pint Quart Peck Bush. early and prolific. The pods are lound, full, stringless, and $\$ 010 \$ 020 \$ 030 \$ 150 \$ 500$

Currie's Rust-Proof wax. Early flat pods. Good shipper. $\begin{array}{llllll}10 & 20 & 30 & 125 & 400\end{array}$

Davis Kidney Wax. Long, handsome waxy white; flat pods ....................... Flageolet Wax. Valuable for
either private use or market, exceedingly procuctive; pods flat, succulent and tender....

Golden. Wax, Improved. Very early; flat pods, long, string-

Golden Eyed wax. hardy and prolific, with flat yellow pods; very early and free from rust; a very desirable and popular sort........

Hodson Long Pod $\mathbf{w} \mathbf{w}$. New; plants grow $21 / 2$ feet high, producing enormous numbers of waxy-cream colored pods, 7 inches long, tender and fine ............. Podded Flat wax. The largest podded bush bean ever offered. Gives the best satisfaction as a Midsummer or Fall wax bean. Exceptionally heavy cropper. . Noll's New Golden Queen. A new rariety which will supersede all the other varieties. Producing enormous plants, enormous pods and enormous yield ............

Refugee Wax. ${ }^{\mathrm{A}}$ perfect Refugee, with long, round, wax pods; suitable for early or late sowing; immense yielder ..................

valentine wax. An $_{n}$ extra early Valentine with round wax pods, possessing the excellent features of the green-podded sort. A great rielder of handsome waxy yeliow pods, solid, meaty, and almost stringless.

Wa r d w e 11 Kidney Wax. Early; long, flat, purely wax

Yosemite Mammoth $_{\text {wax. }}$. Very long, thick, solid pods of finest quality .............

$\begin{array}{lllll}10 & 20 & 30 & 125 & 400 \\ 10 & 20 & 35 & 150 & 550 \\ 10 & 20 & 35 & 150 & 500 \\ 10 & 20 & 30 & 150 & 500 \\ 10 & 20 & 30 & 150 & 500\end{array}$

$30 \quad 175$

650

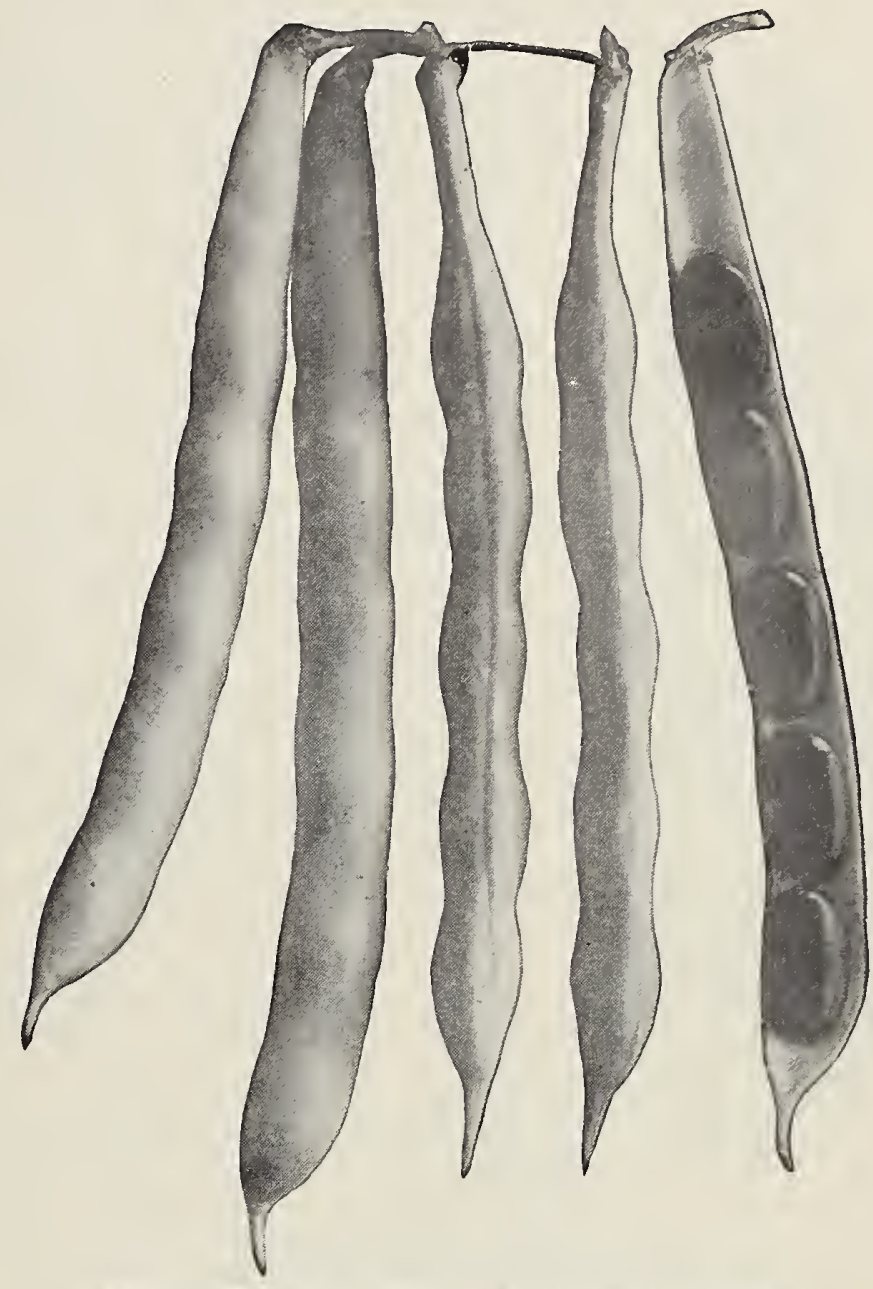

NEW CALIFORNIA RUST-PROOF DWARF WAX BEAN

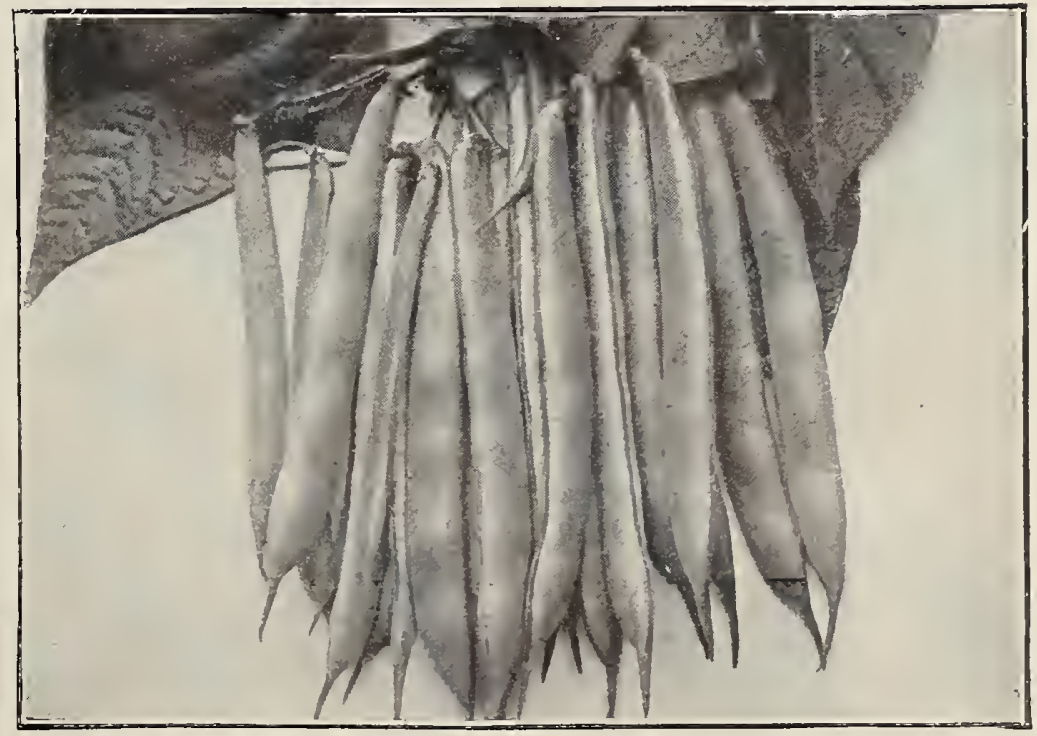

NOLL'S NEW GOLDEN QUEEN BEAN 


\section{LIMA BEANS}

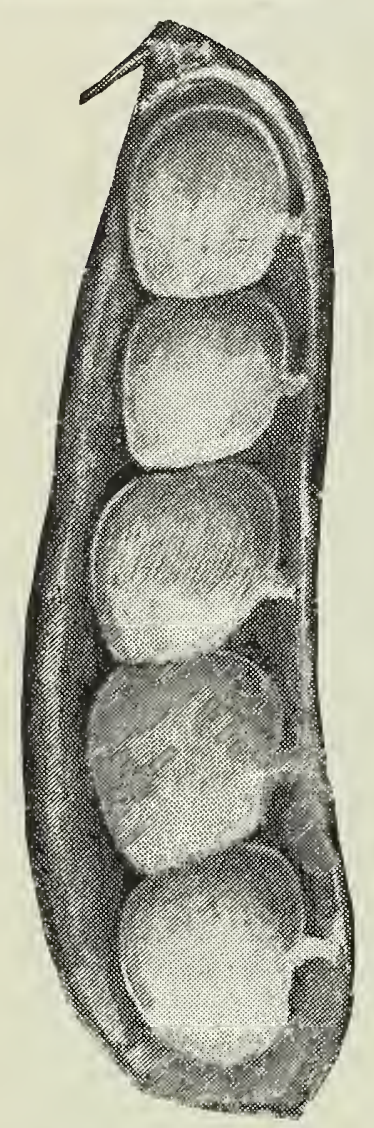

NOLL'S IDEAL POTATO POLE LIMA BEAN

\section{NOLL'S}

IDEAL POTATO

POLE LIMA BEAN

Similar to the Dreer's Pole but earlier, longer pods and more prolific.

The variety of Lima Beans for the gardener to grow. Shells out more quarts of beans to the bushel of pods than any other Lima Bean.

The pods are produced in clusters and average four to five inches in length, containing thick beans of elegant quality. One of our customers in Cuba who shipped his crop to New York market the past season realized out of three bushels of seed an average of eight dollars per crate. 1/2 pt. 15 c., pt. 25 c., qt. 40 c., pkx. $\$ 2.25$, bush. $\$ 8.00$.

\section{POLE LIMAS}

Early Leviathan Lima. Ripens earlier than any pole variety; very productive $\quad \ldots \ldots \ldots \ldots \ldots \ldots \ldots \ldots \ldots \ldots \ldots \ldots \ldots \ldots \ldots \ldots \ldots \ldots \ldots 015 \$ 025 \$ 040 \$ 200 \$ 750$

Ford's Mammoth-Podded Lima. Largest podded Lima offered; very

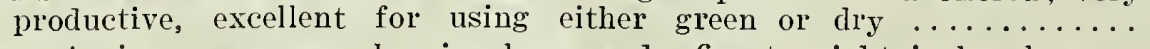

King of the Garden Lima. A vigorous grower, bearing large pods, five to eight inches long...

Large White Lima. One of the old favorites, producing large, flat, kidney-shaped beans.......

Jersey Extra Early Lima. Matures a few days earlier than King of the Garden; good quality.

Dreer's Improved Lima. A very early variety of great productiveness, excellent quality, beans

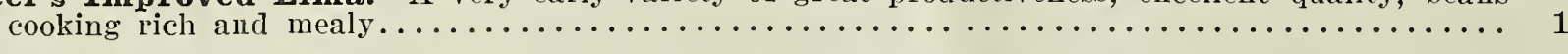

$\begin{array}{llllll}10 & 20 & 35 & 200 & 750 \\ 10 & 15 & 30 & 175 & 650 \\ 10 & 20 & 30 & 175 & 650 \\ 10 & 20 & 35 & 200 & 750 \\ 10 & 20 & 35 & 200 & 700\end{array}$

\section{BUSH LIMA BEANS}

Noll's Ideal Potato Bush Lima. Sells more readily in the market than any other variety;

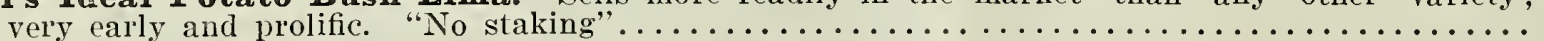

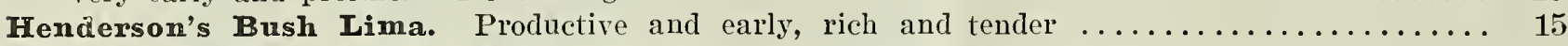

Burpee's Bush Lima. One of the best Bush Lima Beans, growing about 20 inches high...... 10

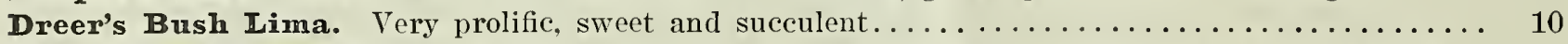

New Wonder Bush Lima. A distinct variety, earlier and a surer cropper than Burpee's Busl.. . 10

$\begin{array}{llll}25 & 40 & 225 & 800 \\ 25 & 40 & 200 & 750 \\ 20 & 35 & 200 & 700 \\ 20 & 35 & 200 & 750 \\ 20 & 35 & 200 & 700\end{array}$

\section{BEANS, CLIMBING OR POLE}

OLD HOMESTEAD. Produces pods in clusters, in eighty days from planting; productive and

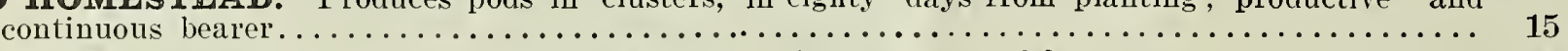

Lazy Wife's Pole. So called because so prolific that it is easy to pick a mess ............

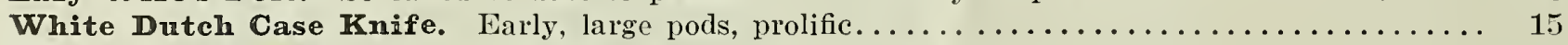

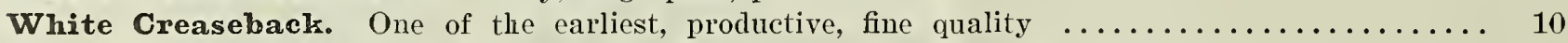

Early Golden Cluster. Bright yellow pods, stringless; very striking in appearance......... 10

Horticultural, or Speckled Cranberry. An old popular variety, also used as a shell bean... 10

Scarlet Runner. Produces large scarlet flowers, also large green-podded beans $\ldots \ldots \ldots \ldots$

25

25

25

20

20

20

20

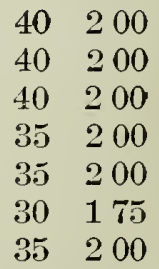

$40 \quad 200$

$40 \quad 200$

$40 \quad 200$

$35 \quad 200$

$30 \quad 175$

35200 


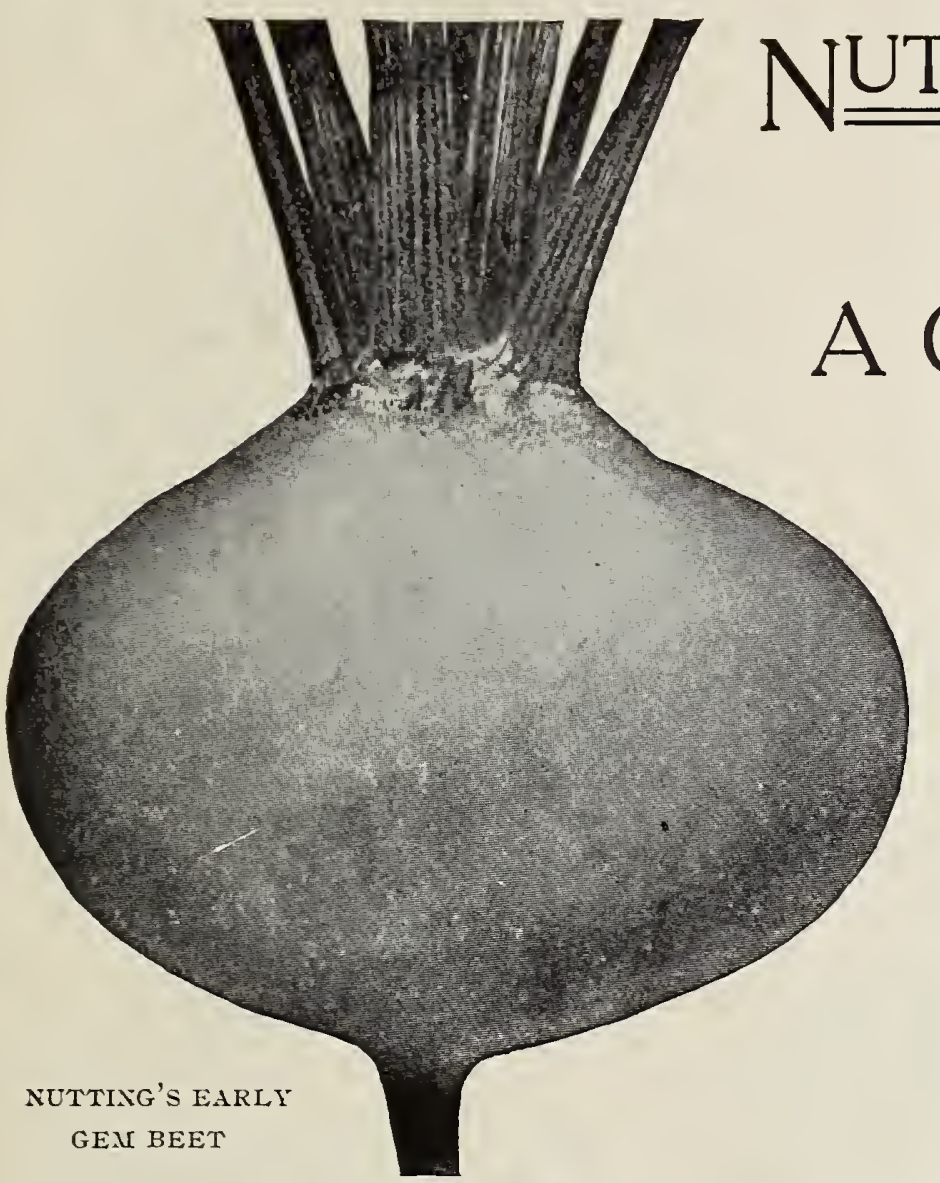

NUTTING'S E $\underline{\underline{\text { ARLY }}}$ GEM BEET

Noll's Selected Strain

\section{CROSBY'S IMPROVED EGYPTIAN BEET}

A selection out of the well-known Egyptian variety, and is an excellent first early sort, uniform in shape, dark red in color. The tops are small, yet large enough to bunch easily. Next to our Nutting's Early Gem, beliere this is the earliest varietr and one of the most satisfactory to grow. Pkt. 5c., oz. 10c., 1/4 lb. 20c., lb. 50c.

\section{INCOMPARABLE SECOND EARLY BEET}

This is, without doubt, the finest second early market beet ever introduced. The root is medium in size, rich dark red in color, which it retains when cooked. For table use scarcely any variety can equal it in fine quality. The top is large; does not wilt down during, nor after, being pulled in warm weather. This alone will cause it to be highly appreciated by every marlet gardener. We also recommend it to all who have a fanily garden. All our customers praise it highly. Pkt. 5c., oz. 10c., 1/4 lb. 20c., lb. 60c.

\section{DETROIT DARK RED BEET}

\section{A FINE STRAIN OF TURNIP-SHAPED BEET}

Valuable for its remarkable uniformity and smoothness; size medium; flesh fine grained, tender and remaining so for a long time admirable for either summer or fall use. The roots are "rea. blood" color, smooth and uniformly round and never get "woody." The tops are dark-colored and rigorous. It is one of the best varieties for bunching and will be found equalls as good to store for winter marketing for when "topped" and heaped in measures it is very showy. Pkt. 5c., 0z. 10c., 1/4 Ib. 20c., lb. 50c.

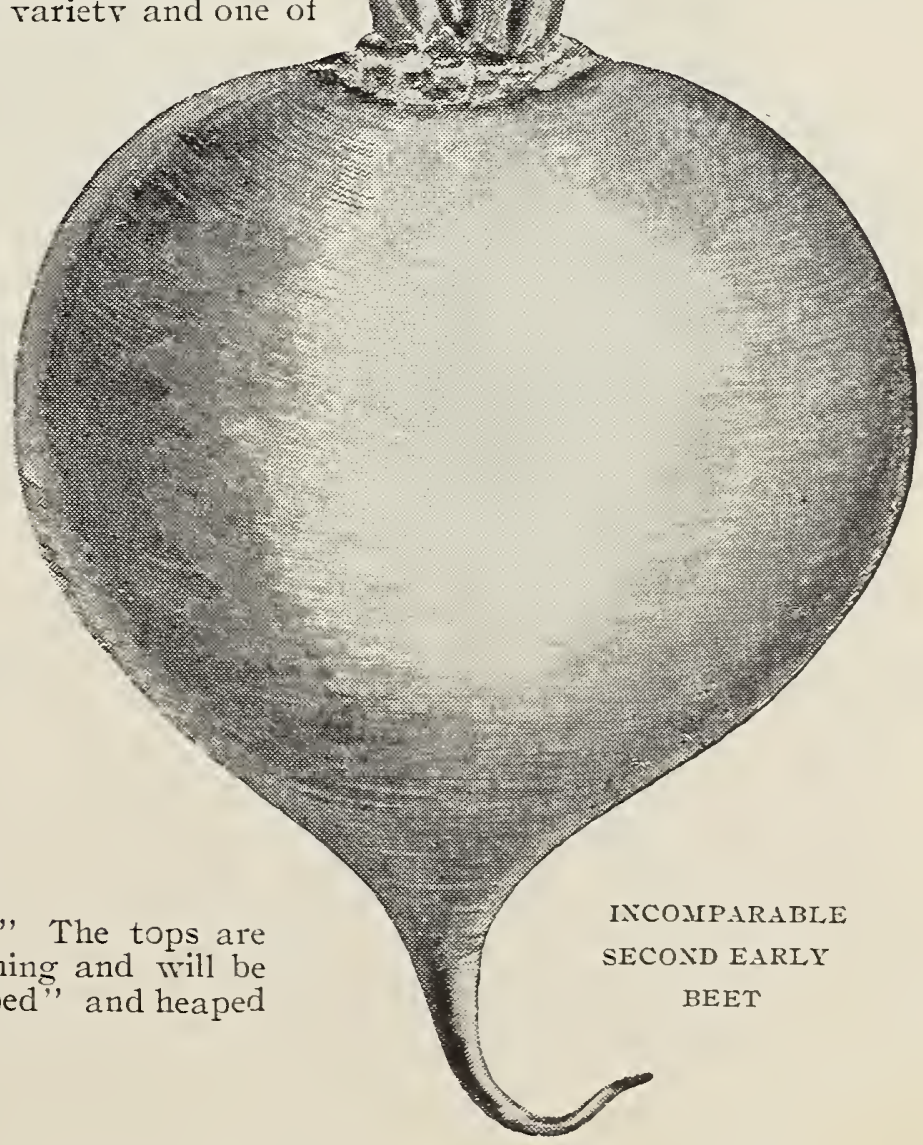




\section{BEETS-Continued-One os. to 50 feet of drill.}

\section{NOLL'S \\ INVINCIBLE BEET}

A new variety which is especially adapted for sowing in Summer to pit or trench for Winter. It is a dark red blood beet with strong toliage. It holds its color and does not rot or decay as easily as other varieties. A fine beet for pickling, being tender, sweet and juicy. Pkt. 5c., 0z. 10c., 1/4lb. 20c., lb. 60c.

\section{STRASBURG HALF LONG BEET}

One of the finest half long beets cultivated. It has a beautiful dark red color and the quality is unsurpassed by any half long variety. An excellent baslet or barrel beet, Pkt. 5c., oz. 10c., 1/4lb. 20c., lb. 60c.

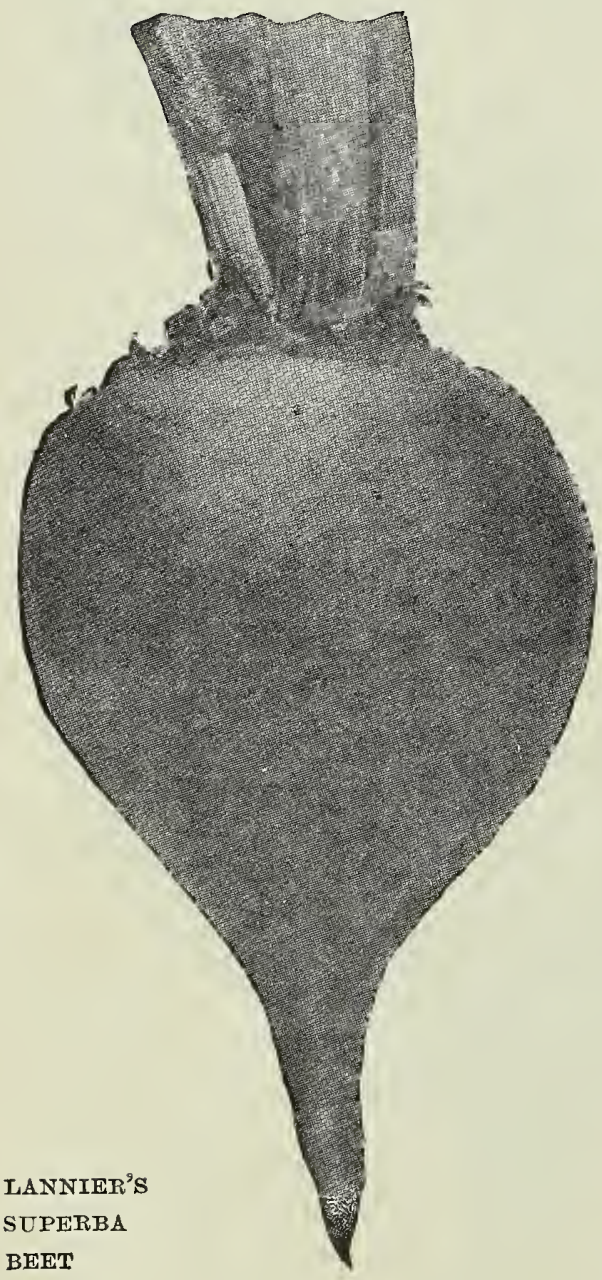

Arlington Improved. Uniformly shaped, superior quality, free from bitterness......................... \$0 $05 \$ 010 \$ 020 \$ 050$

Baltimore Half-Long. A dark, blood, half-long beet, smooth and dark in color; an excellent variety to sell by the basket

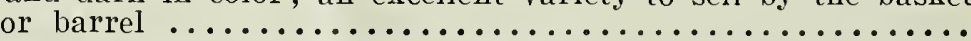

Bassano. Early flat variety, very sweet................

Bastian's Blood Turnip. Of bright color, excellent quality..

Crimson Globe. Fine shape, smooth skin, sweet and tender;

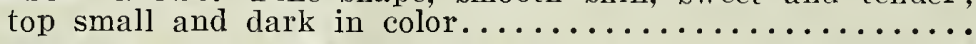

Dewing's Improved Blood Turnip. An improved variety of

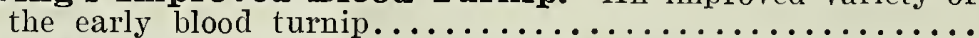

Early Model. Blood red, extremely smooth, fine, rich color,

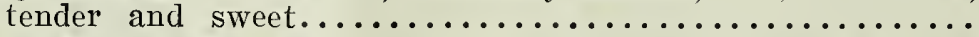

Early Blood Turnip. One of the standard varieties, tops

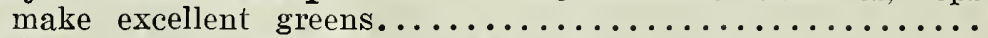

Eclipse. Remarkable for rapid growth; smooth and round,

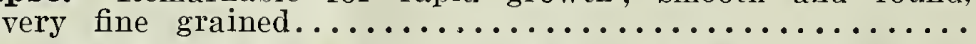

Edmand's Blood Turnip. A handsome variety to follow the

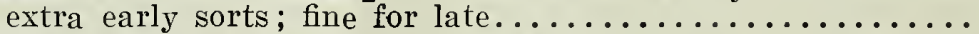

Egyptian Extra Early. A fine forcer, small top, dark red

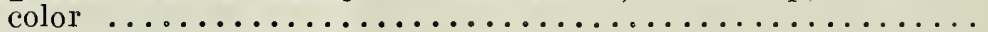

Electric. An extra early blood turnip beet, small top, flavor

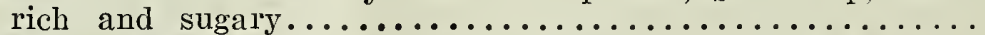

Half-Long Blood. Bulbs are pear-shaped, tender and sweet;

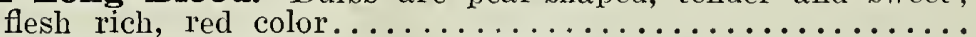

Lannier's Superba. Of a beautiful bell shape, between a turnip and a half-long beet; splendid dark, carmine color,

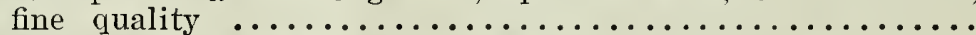

Lentz Turnip. Dark red and white; early and prolific........

Long Smooth Blood. A good late variety for Fall and Win-

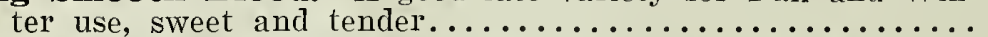

Noll's Dark Red Globe. A perfect type of blood beet, and

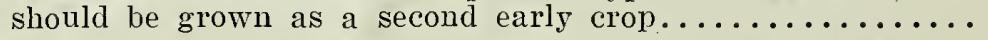

Swiss Chard. Prepared for the table in same manner as spinach; mid-rib can be prepared like asparagus...........

05

05

05

10

05

10

05

05

05

05

10

05

05
-NOLL'S DARK RED GLOBE BEET

For Sugar Beet and Mangel Wurzel, see page 36 . 


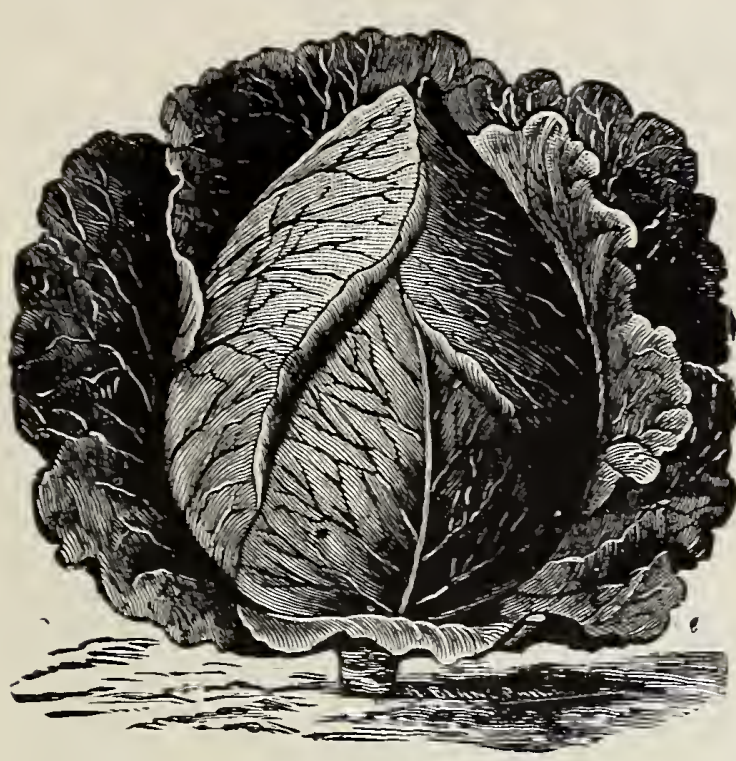

EARLY JERSEY WAKEFIELD CABBAGE

\section{Brussels Sprouts} HALF-DWARF IMPROVED

The best variety for the gardener to grow. A great improvement on the old tall-growing sort, being more dwarf and compact. Produces sprouts of larger size and quality. Pkt. 5c., oz, 25 c., $1 / 4$ 1b. 75 c., 1b. $\$ 2.50$.

\section{Borage}

The roung leares of this annual, which smell somewhat like a cucumber, are used as a salad, or boiled like spinach. Should be sown at intervals, as the leaves are palatable only when young. Sow in the Spring, in light soil; transplant in shallow drills, a foot apart, when of six meeks' growth. Pkt. 5c., oz. 10c., 1b. $\$ 1.00$.

\section{Pride of Erfurt Cabbage}

An Extra Early Round-Headed Variety, as Early as Charleston Wakefield and Yielding More Than Any Other Extra Early.

\section{Noll's Improved Strain}

Market

\section{Gardener's}

\section{Cabbage}

The grandest cabbage in existence. Quick growing, perfect in type and suitable

for Spring, Summer or

late use. Heads are flat, hard and uniform, averaging 12 lbs. in weight.

Can recommend it for the market gardener, trucker or private planter, as it is a perfect Cabbage in every respect, handsome color and fine qualits. One of our customers in Churchland, Ta, wrote us a short time ago that in nearly thirty sears of raising cabbage he could find nothing to surpass it or even equal it and he has tried all varieties. We cannot praise it too highly. Pkt. 10c., oz. 30c., 1/4 1b. 85 c., lb. $\$ 3.00$.

\section{Noll's New White Globe Cabbage}

Especially Adapted for High and Dry Soils

Making splendid heads as round as a cannon ball. It is rery uniform and solid and in this respect it is a wonder: has heads of about equal size and shape, weighing from ten to fifteen pounds each. Quality is of the rery best. Flesh is exceedingly firm, tender and white, making it most desirable for Kraut. It is rers hardr and recommended highly for a Cabbage for late planting. It is rert quick growing and we believe will give the rers best satisfaction. Pkt. 10c., oz. 30c., $1 / 41$ 1b. 85c., 1b. $\$ 3.00$. A cabbage finely bred. somewhat smaller than our Market Gardener's Cabbage. The stem is short with a few outer leares. making almost the whole plant ediole. Its shape and rield make it raluable for truckers, while its quality renders it a fine variety for pricate gardeners. Pkt. 10c., oz. 40c., $1 / 4$ lb. $\$ 1.40,1$ b. $\$ 5.00$.

Noll's Mammoth Red Ball

\section{Cabbage}

B. far the best. largest and hardiest heading red cabbage erer introduced. The plant is large, with numerous spreading leares, and the head large. round, rery solid. and of deep red color inside as well as outside. Pkt. 10c., oz. 30c., $1 / 4$ Ib. 85 c., 1b. $\$ 3.00$.

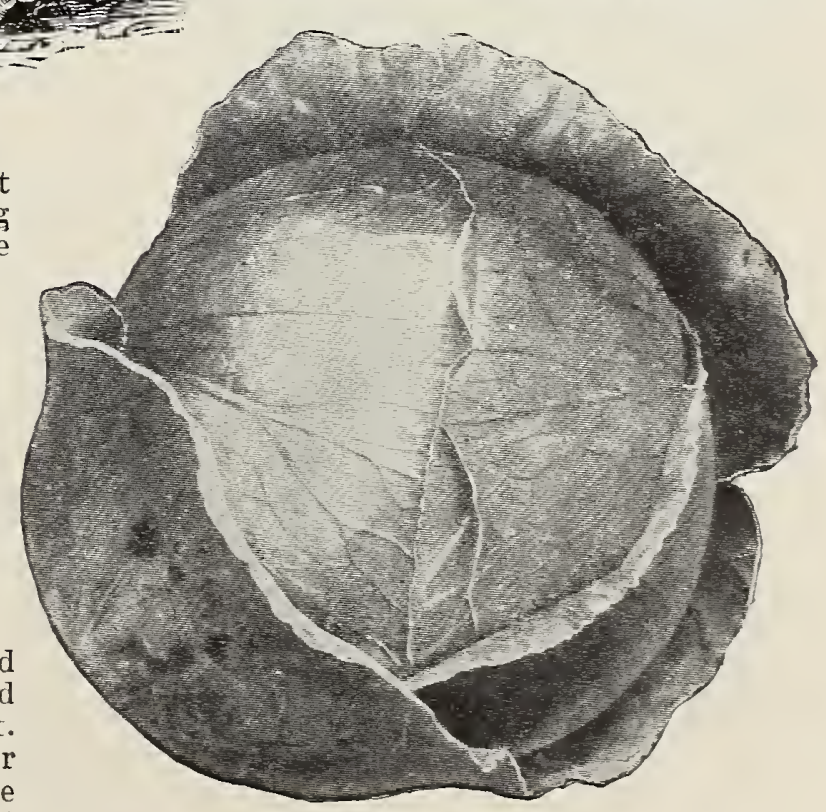

NOLL'S NEW THITE GLOBE CABBAGE 


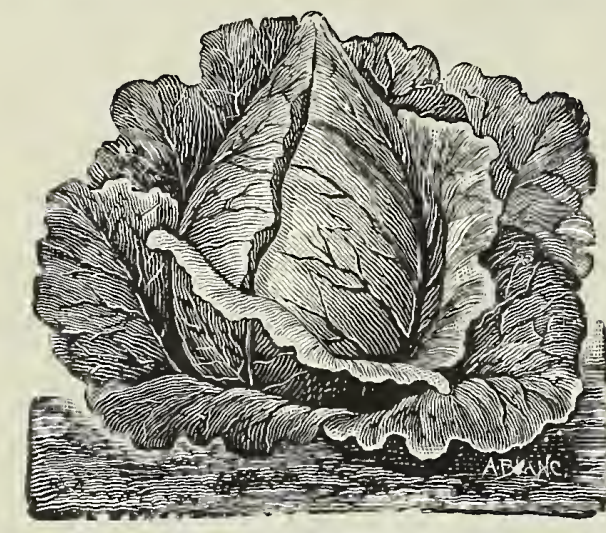

CHARLESTON WAKEFIELD CABBAGE

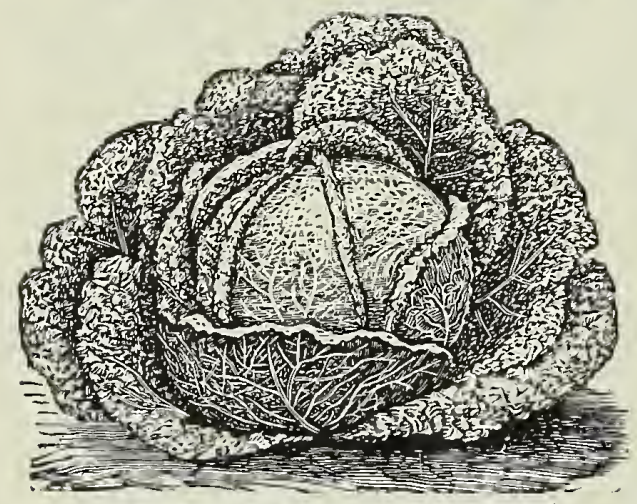

GREEN CURLED SAVOY CABBAGE

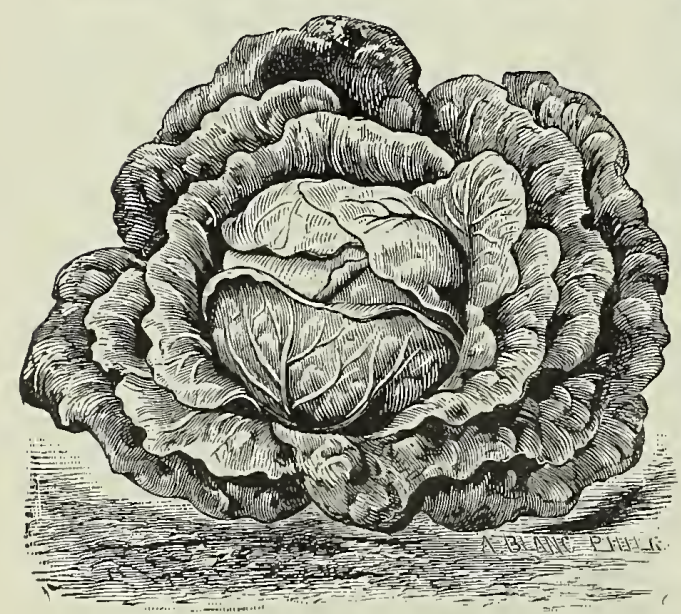

AUTUMN KING CABBAGE

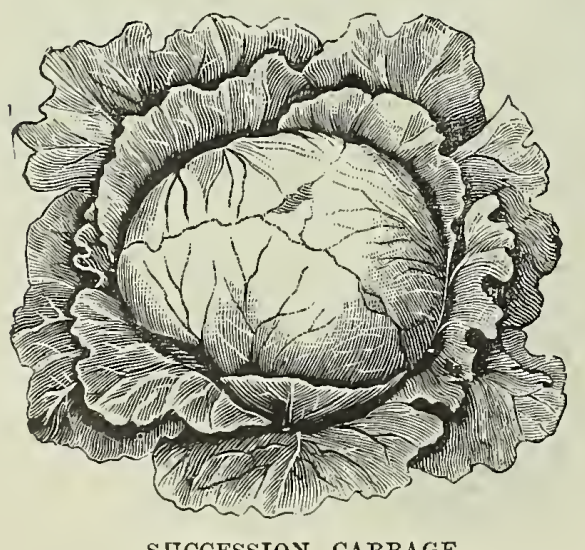

Noll's Perfection * *

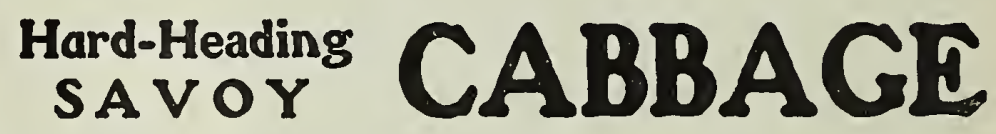

Market gardener's' private stock. This variety, the result of many years' careful selection, is certainly the perfection in the Savoys. It is unquestionably the best and most profitable strain to grow, being far superior to the ordinary imported Drumhead Savoy, as generally sold, the seed of which can be supplied at less than half the price. The heads are large, very uniform, solid and hard, of a deep green color. It is very curly and sure to head, keeps well and retains its color. It is the hest selling market variety of all the Savoys. Pkt. 5c., oz. 25c., 1/4 1b. 85c., 1b. \$3.00.

\section{EXTRA EARLY VARIETIES}

Early Jert. Oz. I/4 Ib. Lb. offer is grown from selected stock.................. $\$ 005 \$ 030 \$ 085 \$ 300$

Charleston Wakefield. A few days later than Early Jersey, producing twice as much per acre as the early variety......

Early Spring. As early as the Jersey Wakefield, heads are

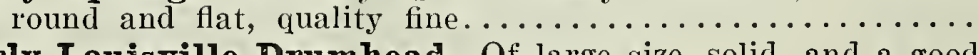

Early Louisville Drumhead. Of large size, solid, and a good

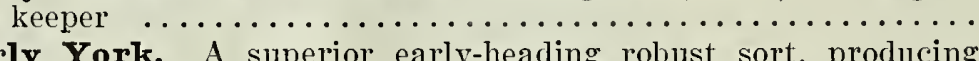

Early York. A superior early-heading robust sort, producing

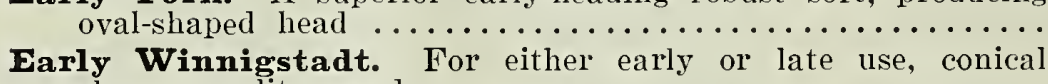
shape, quality good.................................

Stein's Early Flat Dutch. Producing large, flat heads of fine quality $\ldots \ldots \ldots \ldots \ldots \ldots \ldots \ldots \ldots \ldots \ldots \ldots \ldots \ldots \ldots \ldots \ldots \ldots$

\section{SECOND EARLY OR SUMMER VARIETIES}

All Head Early. Largest heading of the second early sorts;

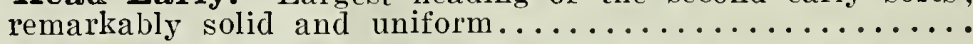

All Seasons. Very desirable, either for early Spring, Summer

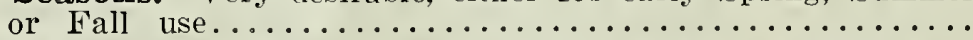

Early Summer. A second early variety, making a large, solid

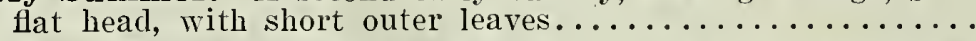

Fottler's Improved Brunswick. Producing immense heads; can be grown as a second early or late sort; short stems,

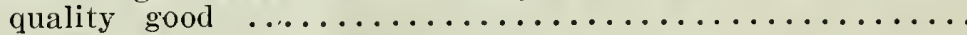

Succession. A good second early, round-headed sort, grown

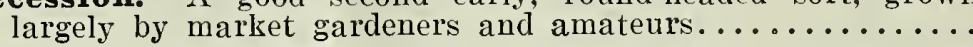

$\begin{array}{llll}05 & 25 & 85 & 300 \\ 05 & 20 & 75 & 250 \\ 05 & 25 & 85 & 300 \\ 05 & 20 & 75 & 250 \\ 05 & 30 & 85 & 300\end{array}$

\section{LATE OR WINTER VARIETIES}

Autumn King. Produces heads of the largest size, very solid,

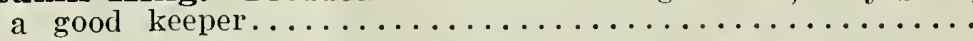

Late Flat Dutch. Large, flat heads, solid and of fine tex-

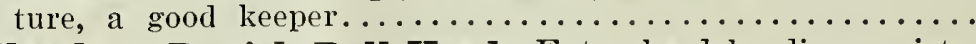

Holland, or Danish Ball Head. Extra hard heading variety,

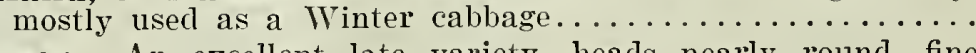

Houser. An excellent late variety, heads nearly round, fine keeper. Claim to be equal in solidness to Danish Ball Head.

\section{RED VARIETIES}

Red Dutch. A large heading variety, fine for pickling...... Mammoth Red Ball. A large growing, select strain, producing solid heads; color, intense dark red............

Mammoth Rock Red. A sure heading sort, large and solid...

\section{SAVOY VARIETIES}

American Drumhead Savoy. Of superior quality; the inside of cabbage is pure white, possessing the rich flavor

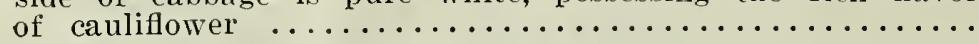

Noll's Perfection, Hard-heading Savoy. See top of page.

$\begin{array}{llll}10 & 30 & 85 & 300 \\ 05 & 25 & 75 & 250 \\ 05 & 25 & 85 & 300 \\ 10 & 30 & 85 & 300 \\ & & & \\ 05 & 25 & 75 & 250 \\ 10 & 30 & 85 & 300 \\ 10 & 30 & 85 & 300\end{array}$


T. F. NOII \& CO.,
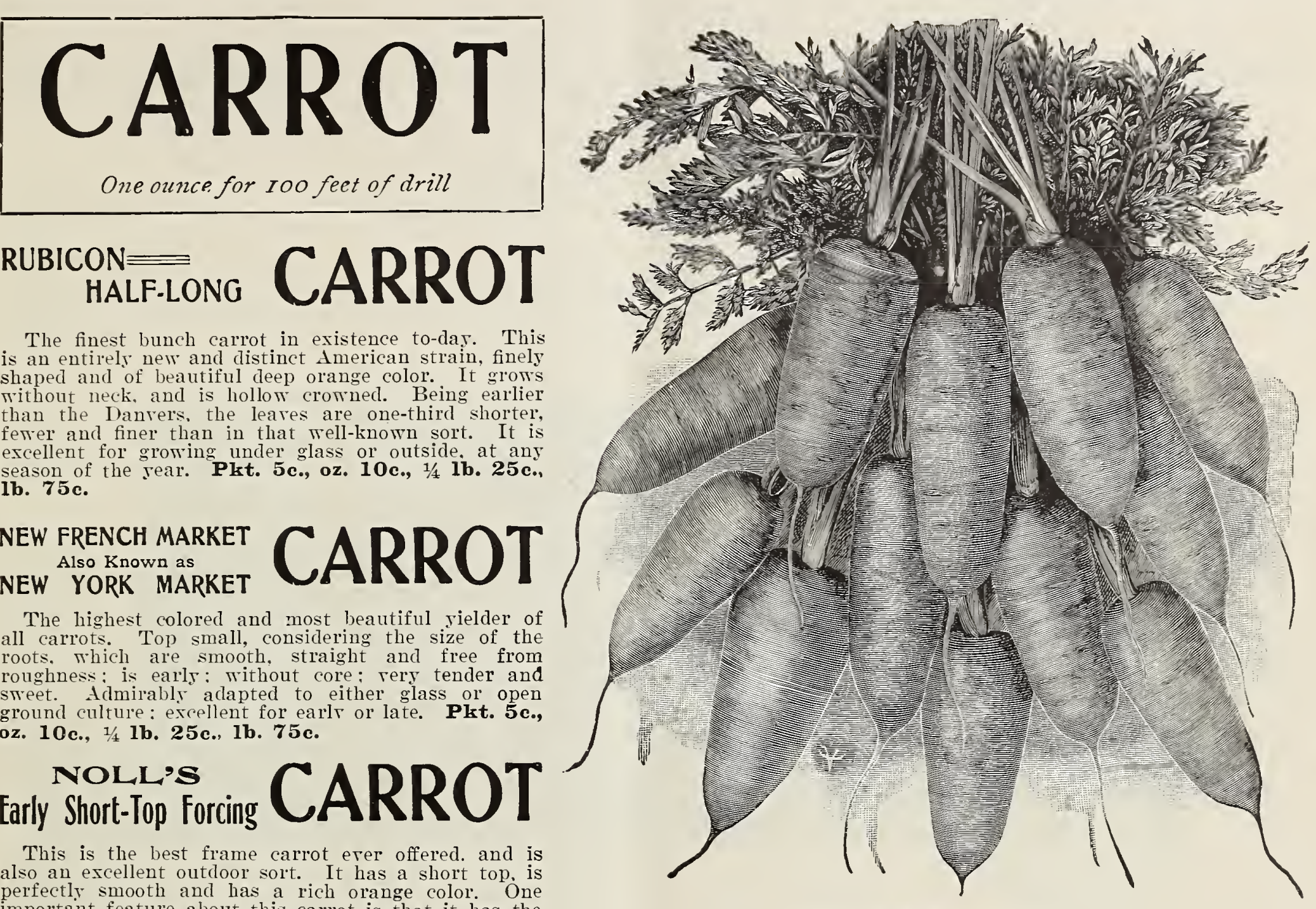

\section{RUBICON HALF-LONG

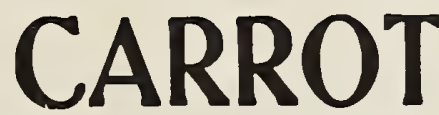

The finest bunch carrot in existence to-dar. This is an entirely new and distinct American strain, finely shaped and of beautiful deep orange color. It grows without neck. and is hollow cromned. Being earlier than the Danvers, the leares are one-third shorter, fewer and finer than in that well-known sort. It is excellent for growing under glass or outside, at any season of 75 c.

\section{NEW FRENCH MARKET NEW YORK MARKET

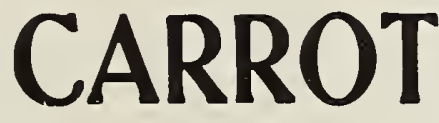

The highest colored and most beautiful pielder of all carrots. Top small, considering the size of the roots, which are smooth, straight and free from roughness: is earls: without core; rery tender and sreet. Admirably aclapted to either glass or open ground culture: excellent for earls or late. Pkt. 5c., oz. 10 c., $1 / 4$ 1b. 25c., 1b. 75 c.

\section{NOLL'S
Early Short-Top Forcing}

This is the best frame carrot erer offered. and is also an excellent outdoor solt. It has a short top, is perfectly smooth and has a rich orange color. One important feature about this carrot is that it has the color desired when it is quite small and does not crack open. Pkt. 5c., oz. 10c., 1/4 1b. 25c., 1b. 90c.

REBICON HALF-LONG CARROT

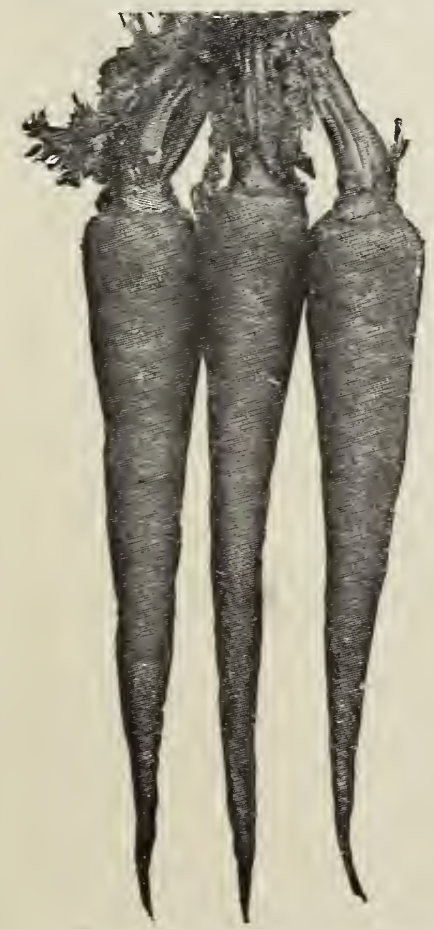

Chantenay Half-Long. Medium earls and hears cropper, fine quality... \$0 05 $\$ 010 \$ 020 \$ 060$

Danvers Half-Long. Earls. smooth and handsome, tops of meditm size:

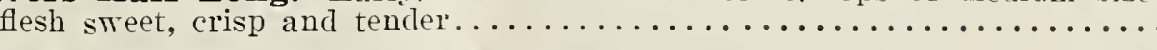

Early French Forcing. One of the earliest, small globular roots, orange

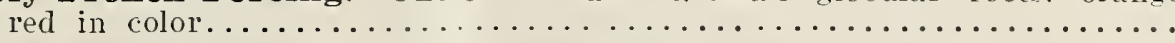

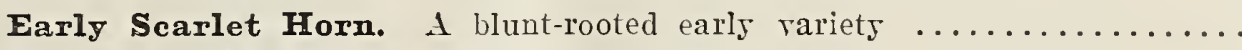

Half-Long Stump-Rooted. One of the best for prirate gardens: grow

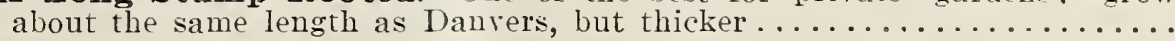

Intermediate. A rery handsome, main crop rariety, wine-colored.....

Long Orange Improved. The largest yielder, and a good keeper......

Long Red Surrey. An excellent long Ninter rariets: and a great improrement on Long Orange. One of the best rarieties for selling br the

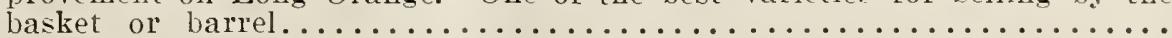

New York Market. A rerr handsome, almost coreless, bright orange car-

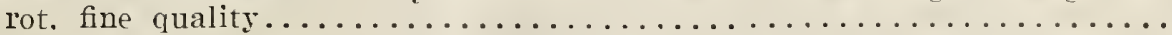

Guerande. A short, thick rariets, suitable for hard soil.

LONG RED SURREY CARROT

Our Carrots are universally known as the finest to be had. We challenge any competition as to their merits. 


\section{Noll's Superior Extra Early Cauliflower}

The Earliest and SUREST HEADER of all the Cauliflowers IT HEADS WHERE OTHERS FAIL

In presenting this early variety to our customers we can confidently state this to be the earliest cauliflower in cultivation to-day, eith 2 for forcing under glass or outdoor planting. Not only is it remarkable for its extra earliness and certainty to produce large, handsome, pure white, heary heads of the finest quality, but its very dwarf, compact habit and short leaves enable it to be planted very close. Pkt. $40 \mathrm{c}$., $1 / 4$ Oz. $\$ 1.50$, oz. $\$ 5.00,1 / 4$ 1b. $\$ 18.00$.

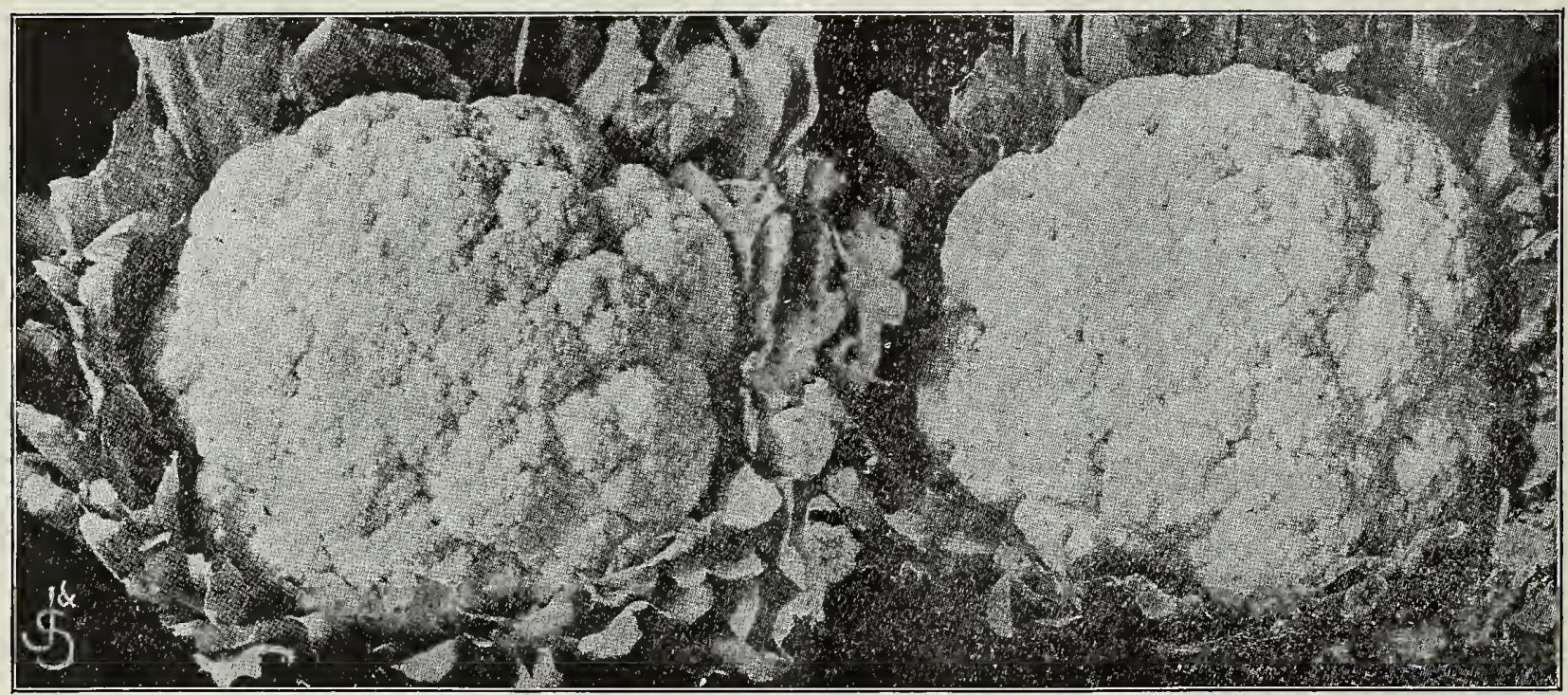

NOLL'S SUPERIOR EXTRA EARLY CAULIFLOWER

\section{Extra Dwarf Erfurt Cauliflower THORBURN'S SUPERB STRAIN}

Extra EARLy DWARF ERfurT is one of the very best varieties for field cultivation, for either early or late, heading with great certainty under conditions at all congenial, producing extra large, deep, solid white "flowers." The plant is of large, sturdy, robust growth, having a strong frame with short, broad leares which furnish ample protection to the "flower." This is of the finest quality, always clear, with even surface, without any leaf growing between and unsurpassed in appearance.

For years we have held the bulk of the trade in sections where large fields of Cauliflower are grown for Eastern markets and almost entirely with this sort. Pkt 20c., oz. $\$ 4.00,1 / 4.16 . \$ 15.00$

Extra Early Paris. Heads uniform, but

Pkt. Oz. $1 / 4 \mathrm{Ib}$ quality and size inferior.............\$0 $05 \$ 0$ \$0 $\$ 275$

Large Late Algiers. A strong-growing variety for late Fall use, producing large, fine heads; popular with canners........

Autumn Giant, Veitch's. A large-growing late variety, succeeding better in Southern climates than any other variety.........

\section{Early Snowball Cauliflower}

Originally recommended and used as an early variety, but it has largely driven out the large late sorts for fall use, being much finer in quality, and certain to head when conditions are ordinarily favorable, forming a perfect snow-white head, averaging not less than 8 inches and often attaining a size of 10 to 12 inches in diameter. It is one of the earliest of Cauliflowers. Its close-growing, compact habit enables one-third more to be planted on the same space of ground than can be done with other varieties. For forcing under glass during Winter and Spring it is well adapted, from its dwarf grow th and short outer leaves, and for this purpose no other Cauliflower is now so largely grown. Pkt. 15c., oz. \$2.50, 1/4 lb. \$9.00, lb. \$35.00.

\section{Corn Salad}

Broad-Leaved (Large Seeded). A delicious salad used during the Wrinter and Spring months as a substitute for lettuce, and is also cooked and used like spinach. Sow in Spring in drills one foot apart. It will mature in six weeks. For early Spring use sow in September and winter over like spinach. Pkt. 5c., oz. 10c., 1/4 Ib. 15c., 1b. 40c. 


\section{Three Most Popular Celeries Grown "Extra Selected Stocks" \\ "Proven Seed" \\ Grown by critical and careful growers in France.}

\section{FRENCH \\ Golden Self-Blanching

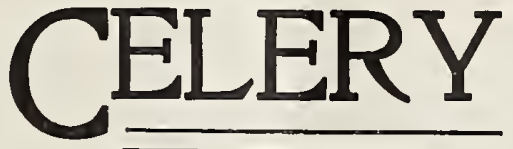

\section{NOLL'S SUPERIOR STOCK}

Our Selected Strain of French Golden Self-Blanching Celery cannot be surpassed. The stock of this variety, which we have offered for the past five years, is pronounced by the best growers of celery to be the finest

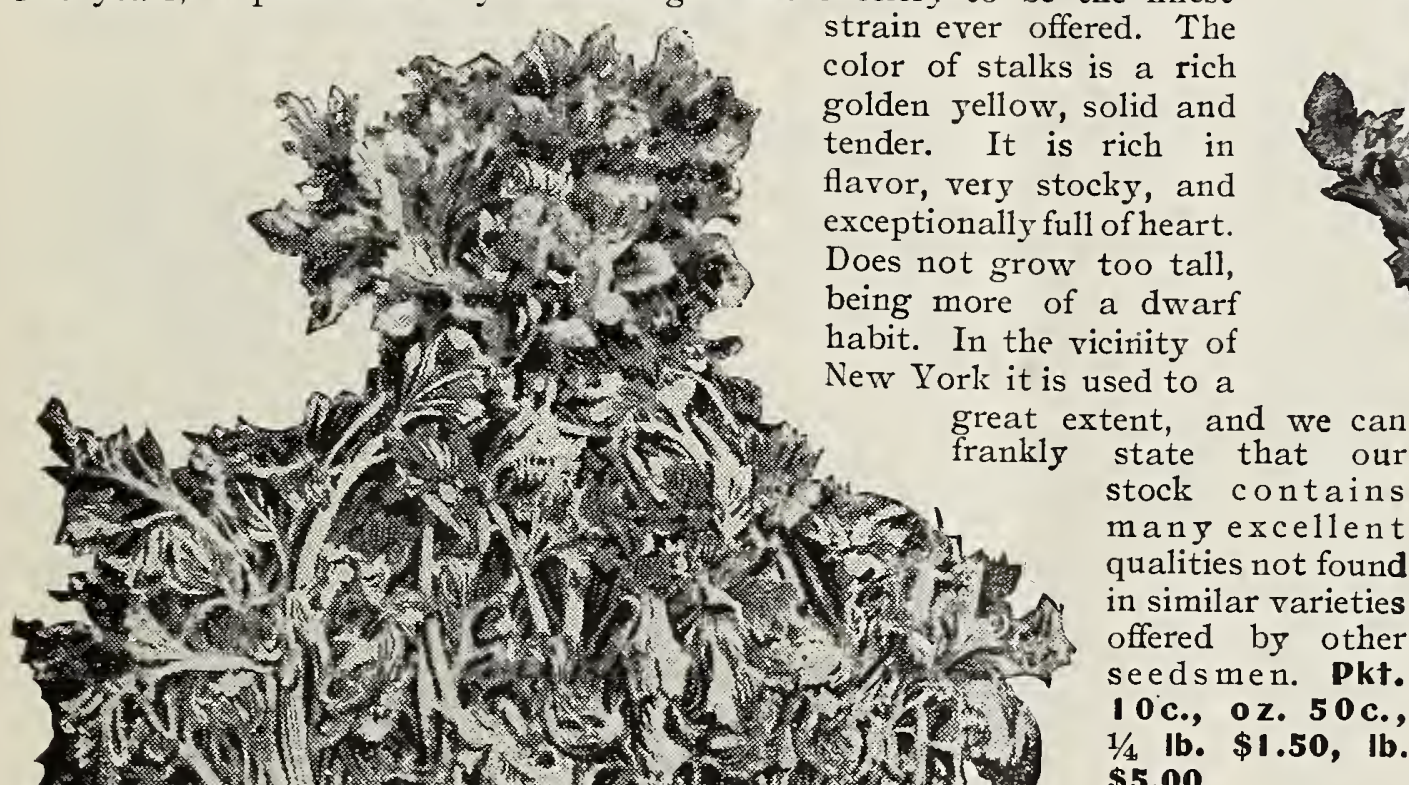

$\$ 5.00$.

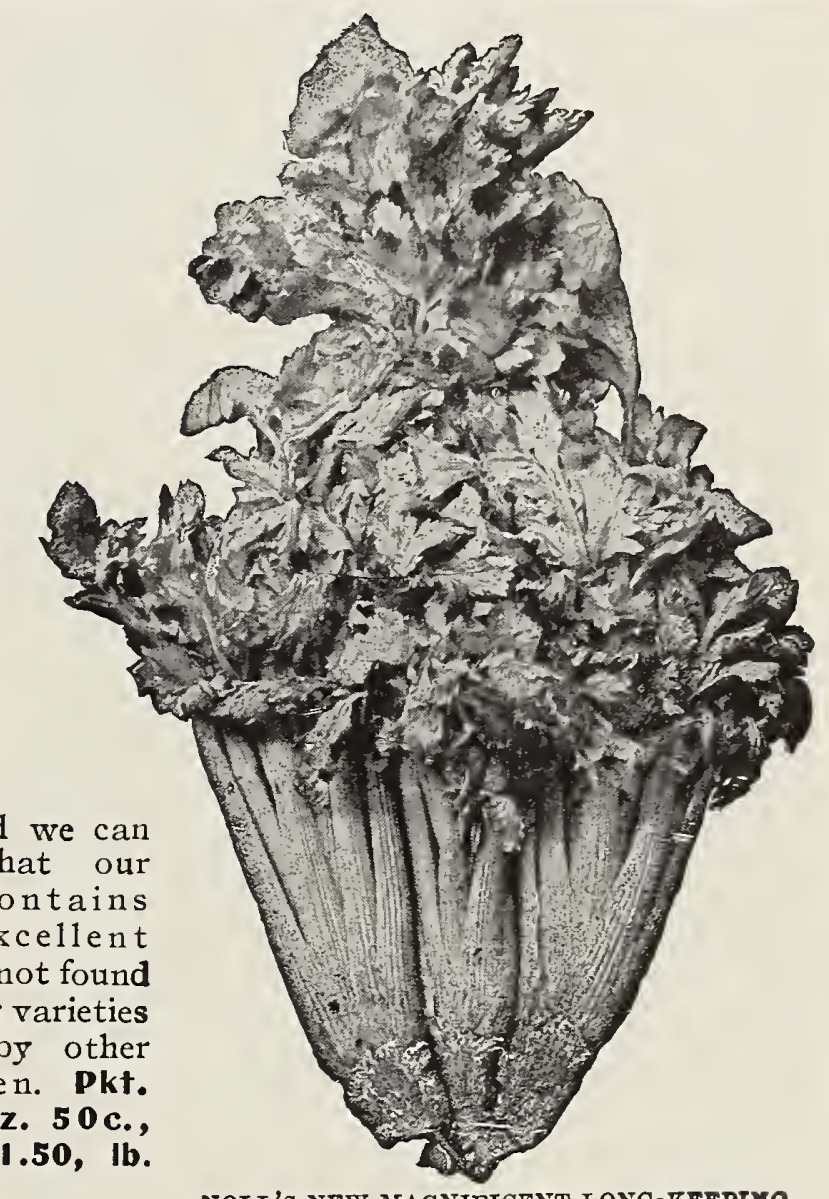

NOLL'S NEW MIAGNIFICENT LONG-KEEPIXO CELERY

\section{NEW LONG-KEEPING CELERY \\ NOLL'S MAGNIFICENT}

The Finest Type of Late Long-keeping Celery Ever Offered Extra Selected Stock. The Best Winter Keeping Variety

This strain is offered by us to Market Gardeners with the distinct understanding that if given a fair trial and not found as represented, we will cheerfuliy refund the price paid for same. This is an unusual offer, but we know that no finer type of green celery can be purchased. It is a late celery of the finest quality, very full-hearted, solid, crisp, and when bleached is of a golden yellow color. It is a good keeper and we cannot recommend it too highly. Pk. I5c., oz. 60c., $1 / 4 \mathrm{lb}$. $\$ 2.00$, Ib. $\$ 8.00$.

\section{NOLL'S Winter King}

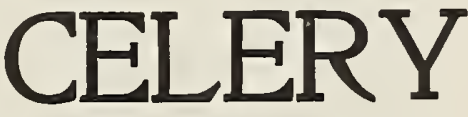

FRENCH GOLDEN ABLF-BLANOHING CELERT
An unusially free growing green celery with many heavy hearts, solid, thick, heavy stalks and when bleached is of a creamy yellow color. This stock was first discovered in Staten Island and since its introduction two years ago has been very much sought after. It is earlier than our "New Magnificent," is not quite as sturdy, but, as some gardeners have remarked, it is early and makes a fine show when ready for market. Has always proved a good keeper. Pkt. I 5c., oz. 60c., 1/4 Jb. \$1.75, lb. \$6.00.

For complete list of Celery see page I4 


\section{CELER Y-Continued-One ounce for 2000 plants}

Boston Market. A variety of superior quality, forms a cluster of heads, and should be blanched by Pkt. Oz. I/4 lb. Lb.

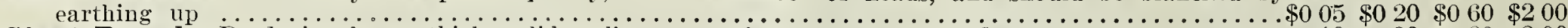

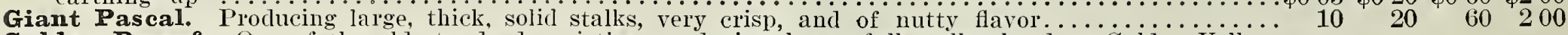
Golden Dwarf. One of the old standard rarieties, producing large, full stalks, hard as Golden Yellow,

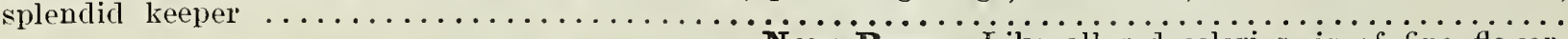

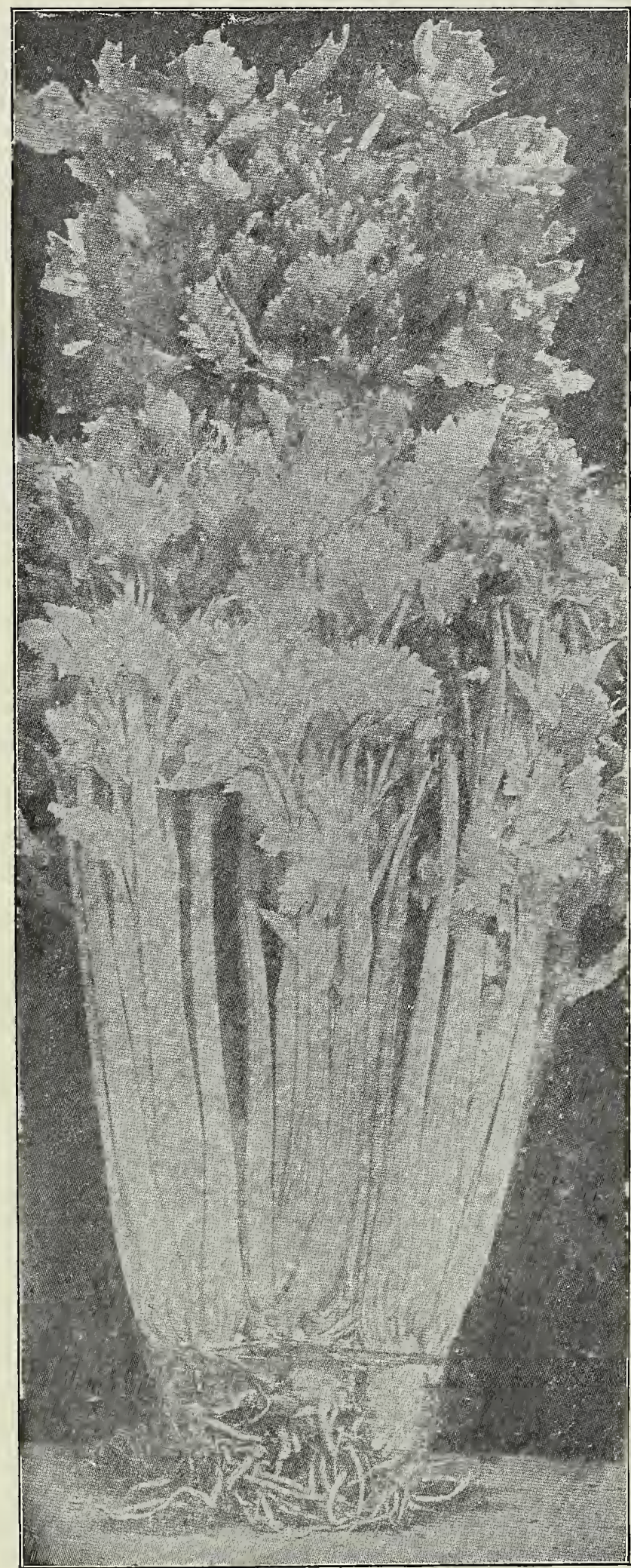

PERFECTEd White PLUMe CELERY
New Rose. Like all red celeries, is of fine flavor, crisp, and an excellent keeper; color is a beau-

Pennsylvania of rose.........................

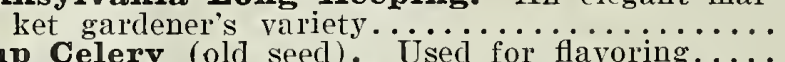

Soup Celery (old seed). Used for flavoring...... White Plume Perfected. A leader among the ing, and is improved by earthing up. Stalks are pure white, crisp, and rich flavor...........

Winter Queen. Extra selected stock, and the finest type of late green celery we offer at a low price. An elegant keeper, full of heart, and solid.

$10 \quad 30 \quad 90 \quad 300$

$10 \quad 25 \quad 85 \quad 300$

$\begin{array}{rrrr}10 & 30 & 100 & 350 \\ & 05 & 15 & 35\end{array}$

$\begin{array}{llll}10 & 30 & 85 & 300\end{array}$

$10 \quad 30 \quad 85 \quad 300$

\section{Celeriac or Turnip-Rooted Celery}

\section{Iurnip-Rooted Celery LargeSmooth Dwarf CELERIAC} Moonarchie

This strain is superior in many respects to the older varieties, as it is finegrained, free from the sideroots which are usually found on most varieties, has a short top and produces a large bulb or knob. It is of a fine quality and good keeper. Plkt. 10c., oz. 25 c., $1 / 4$ 1b. $\quad 75 c ., 1 b$. \$2.50.

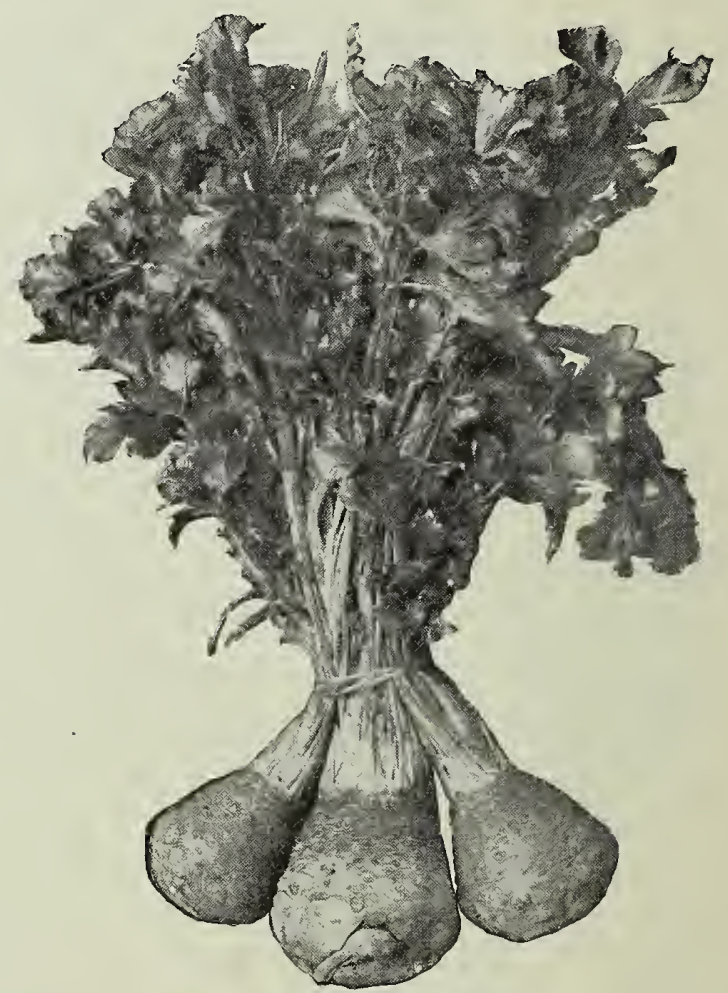

NEW MOONARCHIE CELERIAC

Pkt. Oz. 1/1 lb. Lb.
Large Smooth Prague. One of the largest

smooth skin varieties grown, exceptionally free

from side roots................... $\$ 010 \$ 020 \$ 050 \$ 175$

\section{Chervil}

Used in soups and salads...

\section{Chicory}

Large-Rooted. Used to mix with, or as a substi-

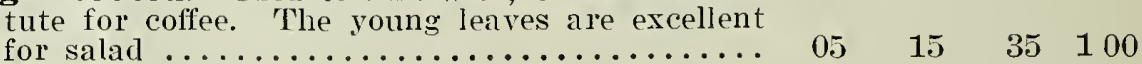

\section{Collards}

Southern. Cabbage greens, used as a substitute for cabbage in the South.............. $05 \quad 15 \quad 35 \quad 100$ 


\section{SWEET CORN}

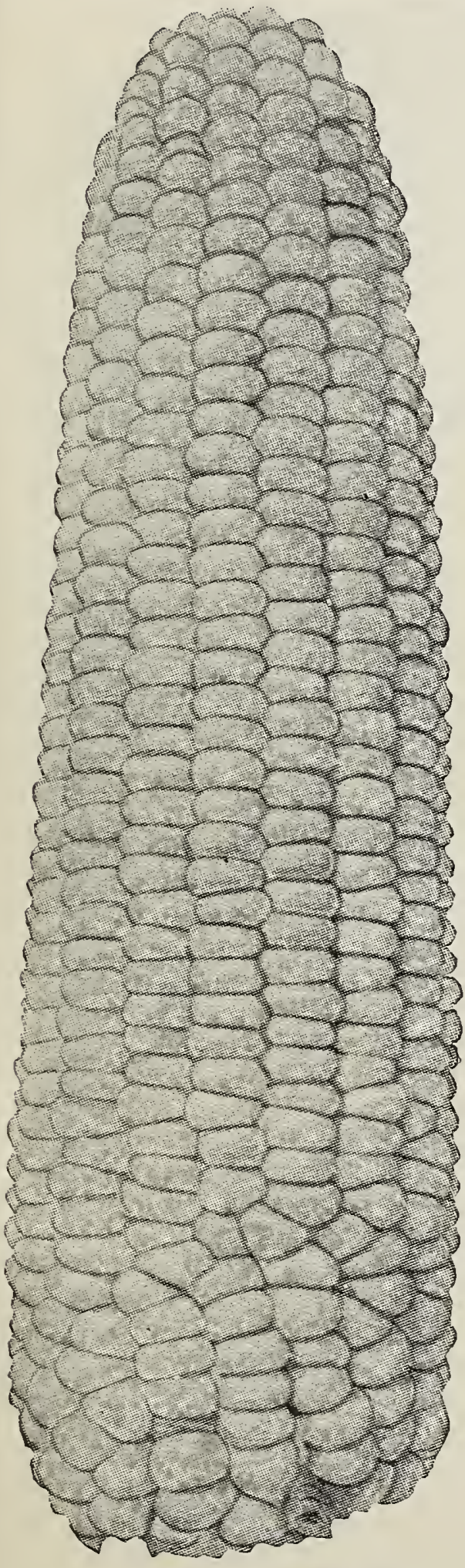

NOLL'S EARLY EXPRESS CORN

\section{Noll's Early Express Corn}

The Finest Early Corn Ever Introduced. A New Early Variety of Strictly Sugar Corn Combining all the Good Qualities of the Later Sorts

It is much hardier, and may be planted some dass earlier without danger of rotting than ans other early kind. It is a vigorous grower, bearing two ears of good quality to the stalk and several days earlier than the White Cors. Our suppls is limited, and rould request early orders for this item. 1/2 pt. 10c., pt. 20c., qt. 30c., pk. \$1.50, bush. $\$ 5.00$.

\section{EARLY VARIETIES}

Red Cob Cory. The earliest, and one of the best early $\frac{1}{2}$ Pt. Pt. Qt. Pk. Bus. varieties grown; good quality................. \$0 $10 \$ 015 \$ 025 \$ 100 \$ 350$

White Cob Cory. Stalks do not grow very tall; rerr prolific, and preterred to the Red Cob Cory............ $10 \quad 15 \quad 25 \quad 100 \quad 350$

Premo. One of the best early varieties, producing a good-

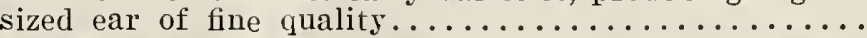

Golden Bantam. A very hearty variety, producing sellow grain of fine quality; very rapid grower........

Metropolitan. An extra early rariety, a few dass later than White Cors, but produces larger ears...........

Early Minnesota. One of the old standard rarieties, coming in a little later than Cory, good quality.....

\section{MEDIUM EARLY VARIETIES}

Early Champion. Medium early, producing large ears, of beautiful white milky grains, tender and sweet....

Perry's Hybrid. A popular second early rariets, producing good-sized ears, set low on the ground........

Stabler's Early. Can be used for marketing, canning, or family use, fine quality...................

Saunder's Second Early. A new rariety, which supersedes all the older second early varieties; rery pro-

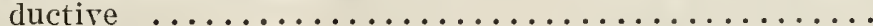

Black Mexican. A medium early variety of exception-

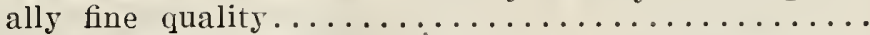

Kendall's Early Giant. Reads for use in sixty to seventy dass; ver's sweet and tender, producing ears about the same size as Early Champion............

White Evergreen. A highly bred type of Stowell's Erergreen, only it is pure white. When in the green

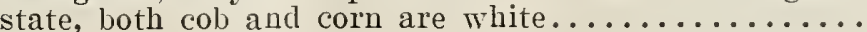

\section{LATE OR MAIN CROP VARIETIES}

Country Gentleman. Ears are medium size, deep grains, irregular rows on cob, and deliciously sweet...

The "Henderson." Matures about the same time as Stowell's Evergreen; good-sized ear of fine quality...

Long Island Beauty. The most prolific rariets of sweet corn ever introduced. quality of the rery best, and exclusively used as a late planting variety...........

Late Mammoth. The largest of all the mammoth rarieties, producing immense ears, often weighing three pounds; extensivel 5 used for fodder to feed green.....

The Moonarchie. Matures about the same time as Storell's Erergreen, but produces larger

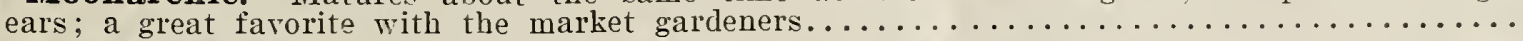

Stowell's Evergreen. One of the most productice rarieties grown, quality of the rery best: remains in good condition, suitable for cooking, for a long time $\ldots \ldots \ldots \ldots \ldots \ldots \ldots \ldots$

$\begin{array}{lllll}10 & 15 & 25 & 100 & 350 \\ 10 & 15 & 25 & 100 & 350 \\ 10 & 15 & 25 & 100 & 350 \\ 10 & 20 & 30 & 200 & 500 \\ 10 & 15 & 25 & 150 & 505 \\ 10 & 15 & 25 & 100 & 350 \\ 10 & 15 & 25 & 150 & 500\end{array}$

$\begin{array}{lllll}10 & 15 & 25 & 125 & 400\end{array}$

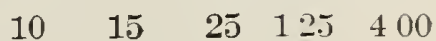

$\begin{array}{lllll}10 & 15 & 25 & 125 & 500\end{array}$

$\begin{array}{llllll}10 & 15 & 25 & 100 & 350\end{array}$

$\begin{array}{lllll}10 & 15 & 25 & 150 & 450\end{array}$

$10 \quad 15 \quad 25 \quad 100 \quad 350$ 


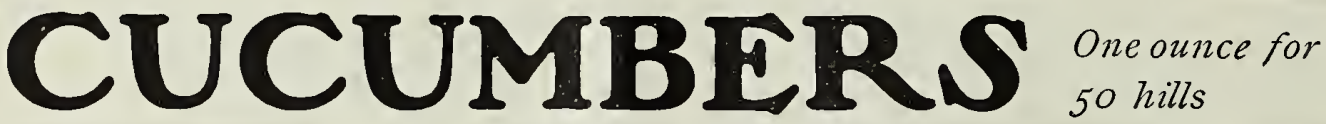

\section{NOLL'S New Early Prolific White Spine CUCUMBER}

Earlier than the Improved Arlington White Spine and a Heavier Cropper. Truckers Who Desire an Early Cucumber Will Find in this New Variety a Money-Maker.

It is one of the most vigorous, strong and robust growers. Fruits are even size, very handsome shape, measuring about 8 to 9 inches in length, and are of a dark green color. The fruits are close to the hill, and are excellent for slicing. Our Southern friends will find it admirably adapted to their wants. Pkt. 5c., oz. 10c., 1/4 1b. 40c., 1b. \$1.50.

\section{Davis' Perfect}

\section{CUCUMBER}

A New Variety Originated by Mr. Eugene Davis, Who First Introduced Davis Kidney Wax Beans.

It is in color a glossy green; shape slim, symmetrical, with an average length of 10 to 12 inches. The quality is fine and of exceptionally good flavor. Another strong point of merit is its shipping qualities; it seems to hold its color and brittleness long after being cut. It is a very strong grower and is able to resist the cucumber disease. This cucumber can be used under glass as well as for growing out of doors. Claimed to cut from 30 to 50 per cent. more cucumbers from the vines of this variety than any other. Pkt. 10c., oz. 25c., $1 / 4$ 1b. 60c., 1b. $\$ 2.00$.

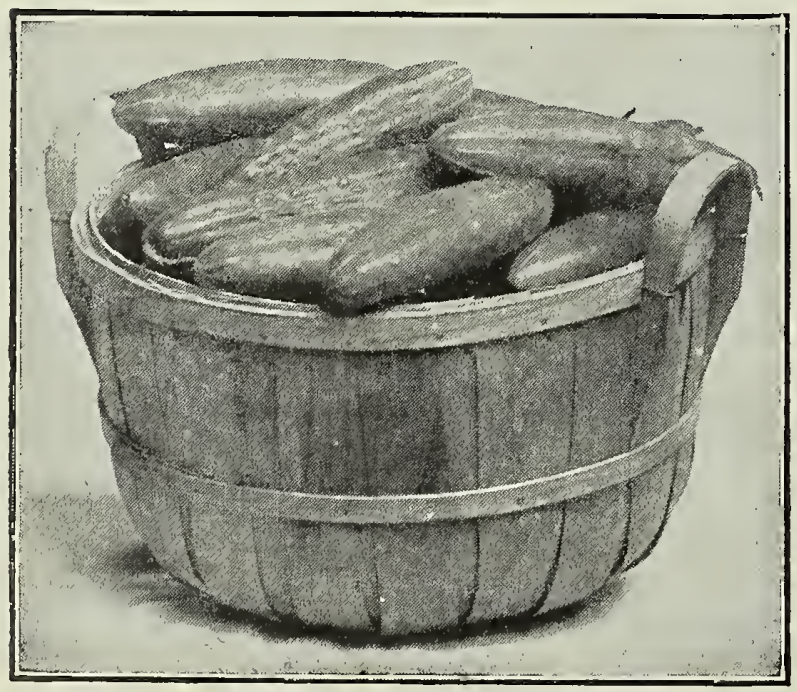

DAVIS' PERFECT CUCUMBER
NOLL'S NEW EARLY PROLIFIC WHITE SPINE CUCUMBER

Cool and Crisp. A strain of White Spine, similar Pkt. Oz. 1/4lb. Lb. to the Arlington. It is early, and continues to bear the entire season................... \$0 05 $\$ 010 \$ 030 \$ 100$

Extra Early Green Prolific. One of the best pickling varieties, dark green............... $05 \quad 10 \quad 30 \quad 100$

Extra Long White Spine. Skin dark green, producing fruits ten inches long. One of the best

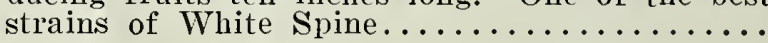

Early Cluster. A very early short green variety.. $\begin{array}{llll}05 & 10 & 30 & 100\end{array}$

Improved Arlington White Spine. A strain of White Spine, which has been improved with

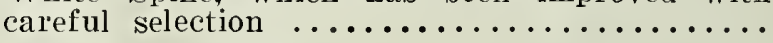

Evergreen. Skin dark green, fruits of medium size; very prolific.....................

Long Green. Fruits are long, firm and crisp ; small fruits are used for pickles; vines are vigorous in growth, and productive.........

Matchless Extra Early White Spine. Very productive, dark green color, and of good size..

Japanese Climbing. Can be grown on trellis, producing large, fine fruits, of good quality...

West Indian Gherkin. A small pickle variety, producing fruits about two inches long.......

\section{CRESS}

Extra Curled. Used for garnishing..........

Water Cress. Should be grown along moist banks; used for salads and garnishing....... $10 \quad 25 \quad 75 \quad 300$

\section{DANDELION}

Common, or French. The variety mostly used by market gardeners $\ldots \ldots \ldots \ldots \ldots \ldots \ldots \ldots$

Improved Thick Leaf. An early improved variety .

\section{FTENTRTTET}

Florence. Usually eaten boiled; in flavor it resembles celery; has a sweet taste, and most

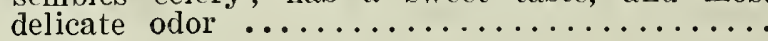

$50 \quad 150$ 


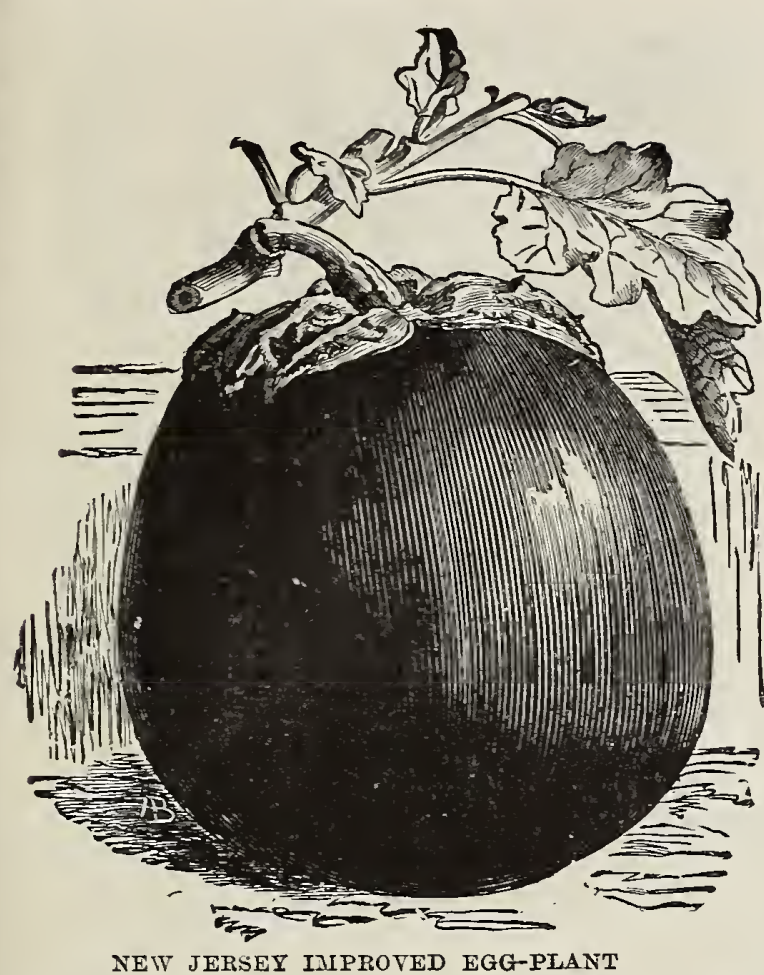

BLACK BEAUTY

This new variety is an excellent market sort. It is about the same size and shape as the New York Improred, except a little fuller at the top; is a few days earlier and a hearier vielder. Its color is a rich purplish black, which it retains even after becoming dead ripe. True stock. Pkt. lOc., oz. $40 \mathrm{c}$., $1 / 4$ 1b. $\$ 1.25$, 1b. $\$ 4.00$.

NEW JERSEY IMPROVED

Large Smooth Stem Dark Purple

Market gardeners and shippers will find this variety the best in cultivation. The habit of the plant is low and branching, and
it is quite free from spines. Leares of a light green shade. Fruit early, very large, oval and of a fine deep purple. Flesh very white, tender and of superior qualits. Pkt. 10 c., oz. 40 c., $1 / 4$ lb. $\$ 1.00,1 b$. $\$ 3.75$.

\section{$\substack{\text { New York } \\ \text { Spineless }}$ Egge=Plant}

Early, prolific; purple fruits of the largest size and perfect in form, Pkt. 10c., oz. 40c., $1 / 4 \mathrm{lb}$. $\$ 1.00,1 \mathrm{lb}$. $\$ 3.75$.
New Smooth White

Short=Leaved

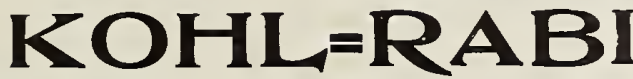

Owing to the increasing demand for this popular European regetable, mans gardeners have added it to their crops. After sereral rears' comparatice tests we find this new sort decidedly the best for market and table use, being much superior to Vienna. It is vers early and best for forcing, as well as for outside growth. Bulb is greenish white, beautiful, smooth shape and of the rery finest texture and quality. Pkt. 10c., oz. 30c., $1 / 4$ lb. 90c., 1b. $\$ 3.00$.

Early White Vienna. Large, quickgrowing; greenish white skin and Pkt. Oz. 1/4 lb. Lb. tender white flesh...............\$0 $05 \$ 020 \$ 0 \$ 0 \$ 200$

Early Purple Vienna. The outside color is purple; flesh white and delicate

Short-Leaved Ea i i Vienna. Early and rapid-growing, with few and small leares; the most delicately flarored; indispensable for frames and forcing; can be planted closels

BROADLEA VED
BATAVIAN ENDITE

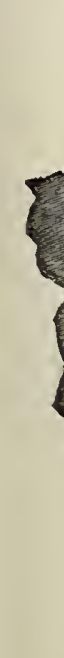

$05 \quad 20 \quad 60 \quad 200$

\section{Mammoth NOLL'S SELECTED STRAIN}

This beautiful and raluable rariety is much superior to the old Green Curled, and grows 15 to 20 inches in diameter, as shomn in photograph. The leares are rery crisp, tufts and full in every stage of growth. The mid-rib is pure white, very hears, thick, fleshy and tender. It is equally suitable for Spring. Summer or Autumn planting, being extremely hardy. Pkt. 5c., oz. 20c., 1/4 1b. 60c., 1b. $\$ 2.00$.

\section{Mammoth \\ Green \\ Bordeaux}

$10 \quad 30 \quad 85 \quad 300$

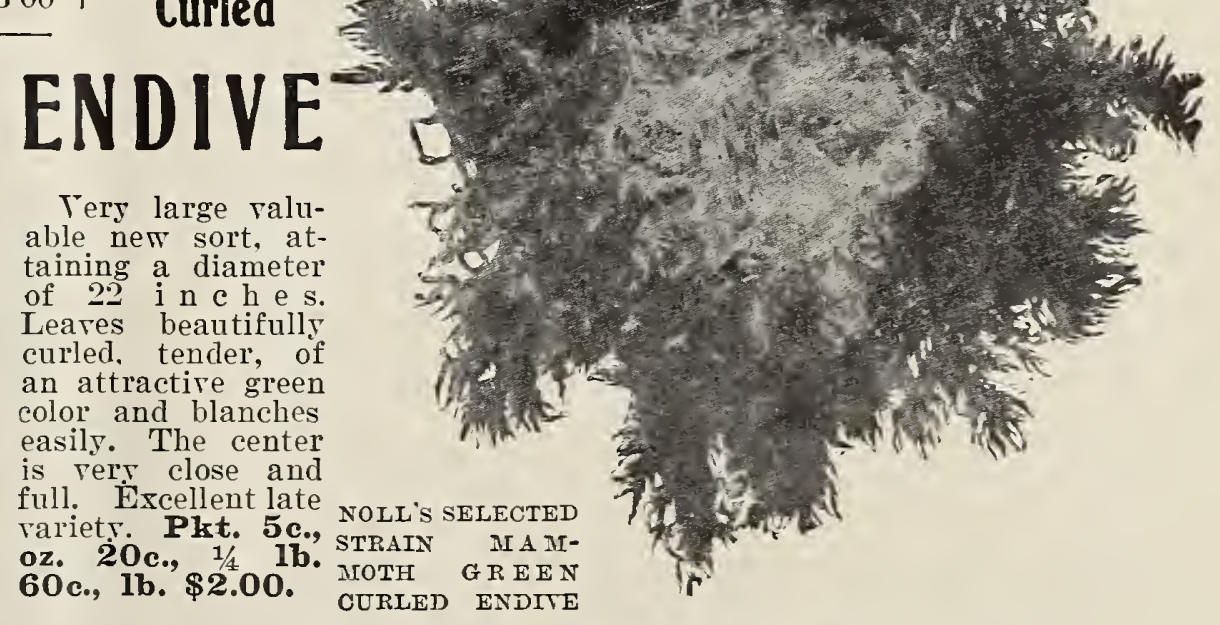

\section{Broad-Leaved Batavian ENDIVE (Escarolle)}

Has broad, thick, slightly wrinkled leares, forming a large head which is preferred for stews and soups; but if the leares are gathered and tied at the top, the whole plant will blanch nicels and make an excellent salad. Pkt. 5c., oz. 20c., 1/4 1b. 60c., 1b. $\$ 2.00$. 


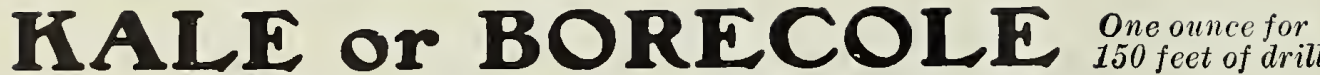 NORFOLK DWARF GREEN CURLED SCOTCH KALE}

This is one of the best Kales for Spring sowing in the North, and is the principal sort grown in the South for Northern markets. It is hardy and will remain over Winter in any place where the temperature does not go below zero. The habit is very ciwarf and spreading, and will rarely exceed 18 inches in height. The leaves are of a bright green color, beautifully curled and produced in great abundance. Pkt. 5c., oz. 10c., 1/4 1b. 20c., 1b. 60c.

\section{NEW IMPERIAL LONG-STANDING OR EARLY BLUE CURLED KALE}

A beautiful curled and crimpled sort, of strong, vigorous habit perfectly hardy, dark rreen color, and very attractive appearance. Superior to all other sorts, and will stand longer without shooting to seed than any other. Pkt. 5c., oz. 10c., $1 / 4$ 1b. Z0c., 1b. 60c.

Siberian. Green, curly leaves; tender and of delicate flavor. Pkt. 5c., oz. 10c. $1 / 4$ 1b. 20c., 1b. 60c.

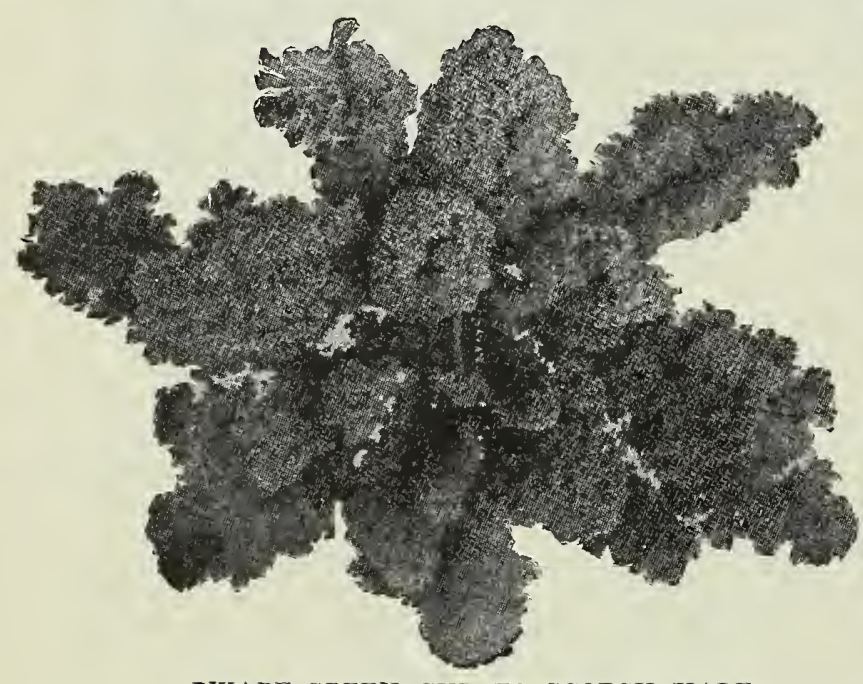

Brown German Curled, or Purple. Purplish, curly leaves. Pkt. 5c., oz. $15 c_{\text {. }}$ $1 / 4$ 1b. 30c., 1b. $\$ 1.00$.

\section{LEEKS}

ne ouncé will sou

NEW GIANT ITALIAN WINTER LEET

This is by far the best variety. It grows long and thick, and is unusually fine grained, tender and hardy. The foliage is of a dark, glossy green, keeps well and will yield double the quantity per acre of any other sort. Pkt. 5c., oz. 20c., $1 / 4$ lb. 40c., $1 \mathrm{~b}$. $\$ 1.50$.

\section{IMPROVED AMERICAN FLAG LEEI}

Selected stock. A good early variety with light green leaves. It is not as thick as Giant Italian, but grows taller. Pkt. 5c., oz. 20c., 1/4 1b. 40c., Ib. $\$ 1.50$.

Musselburgh, or Scotch Champion. Targe-growing, flat-leaved variety, stems 3 in. in diameter by $S$ in. long. Pkt. 5c., oz. 20c., 1/4 1b. 50c., 1b. $\$ 1.50$. Large Rouen. Excellent for either Winter or Autumn use, of slow growth, DWARF GREEN CURLED SCOTCH KALE but slow in running to seed. Pkt. 5c., oz. 20c., $1 / 4$ 1b. 50c., 1b. $\$ 1.50$.

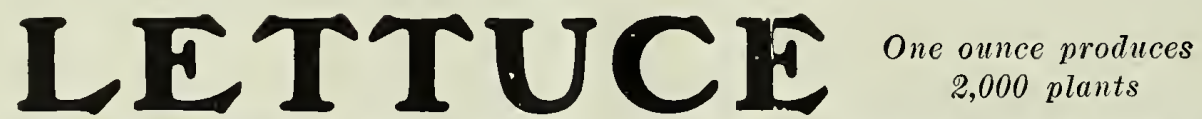

CALIFORNIA GIANT WHITE LETTUCE

For either Spring or Fall use. Big, compact, tender and crisp white heads

Every plant heads, and the heads are uniformly shaped, very large and thick through, and of a solidity equal to that of a cabbage. They meacure about seven inches across the solid head. The leaves are slightly crumpled, of a beautiful white color. It has an attractive appearance, is the best for growing in sash, and excellent as an outdoor Autumn or early Spring crop. The best variety for Southern growers. Unsurpassed for growing in low temperatures. Pkt. 10c., oz. 25c., 1/4 1b. 60c., 1b. \$2.00, 5 lbs. \$9.00. Prices on 25, 50 or 100-1b. lots quoted on application.

\section{IING OF THE GARDEN HEAD LETTUCE}

Sow or plant on ground not too heavily manured-Has produced the largest heads we ever saw

This variety is indeed worthy of its name and we be. lieve it is the finest we can offer our market gardeners and friends for early Spring or Fall planting. The leaves are smooth and of a beautiful light green color, which makes it a ready seller. It is the largest hard-heading variety we know of and we cannot recommend it too highly. Will give the best results in the Spring when sown in the sash and planted out. Plkt. 10c., oz. 25c., 1/4 1b. 60c., 1b. $\$ 2.00$.

THE TWENTIETH CENTURY LETTUCE A strictly all season variety which has made more friends for us and given better results wilh our gardener cusiomers than any other we ever sold

Where it is very similar to our Mammoth Salamander, it stands more heat, grows to a larger size and has a better color. Valuable for private garden as well as to grow for profit. Pkt. 10c., oz. 25c., $1 / 4$ 1b. 60c., 1b. $\$ 2.00$.

\section{CHAMPION OF ALL LETTUCE}

For full description, see page 19

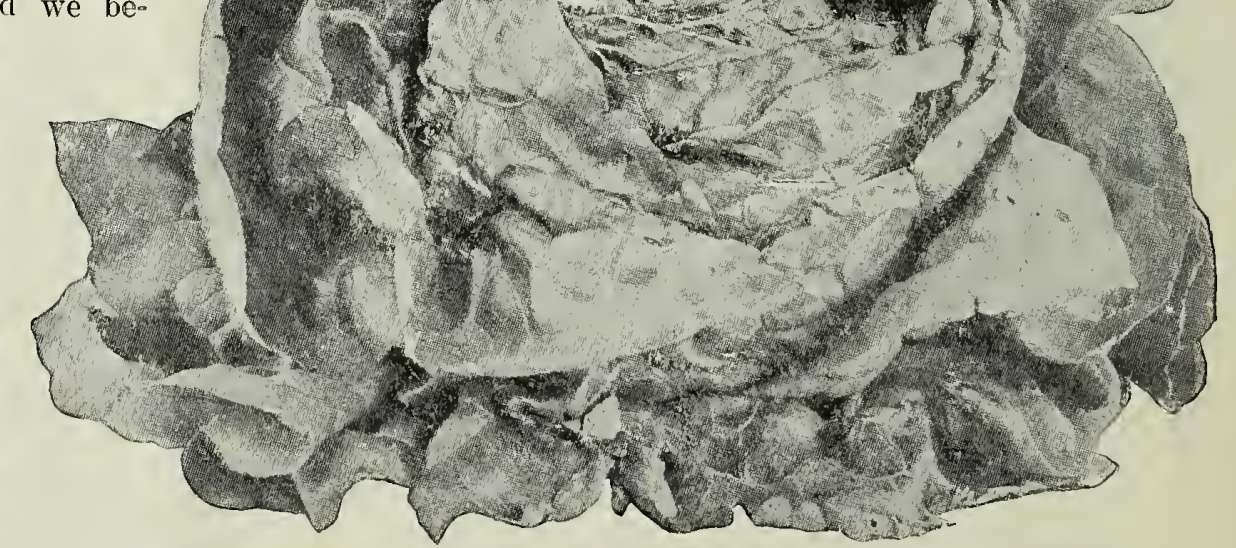




\section{LETTUCE - Continued_One ounce for 2000 plants}

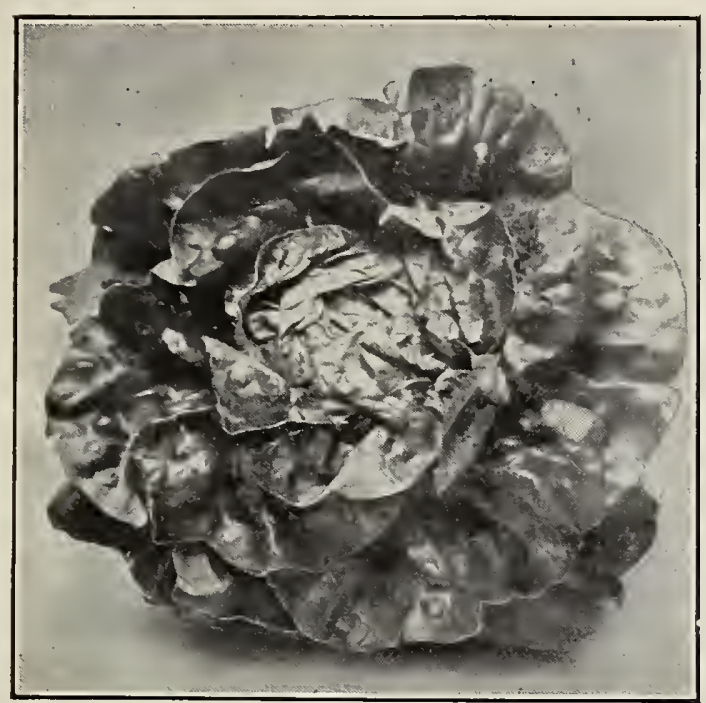

NOLL'S CHAMPION OF ALL LETTUCE

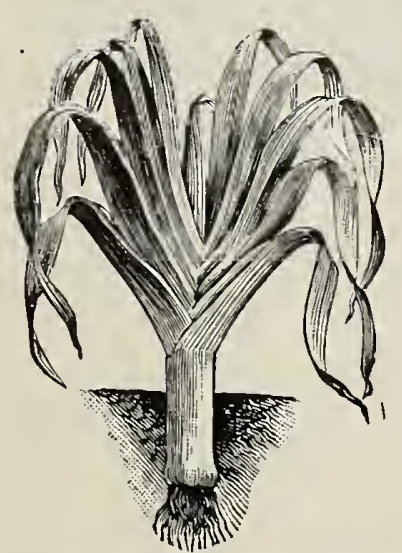

IARGE AMERICAN FLAG LEEK

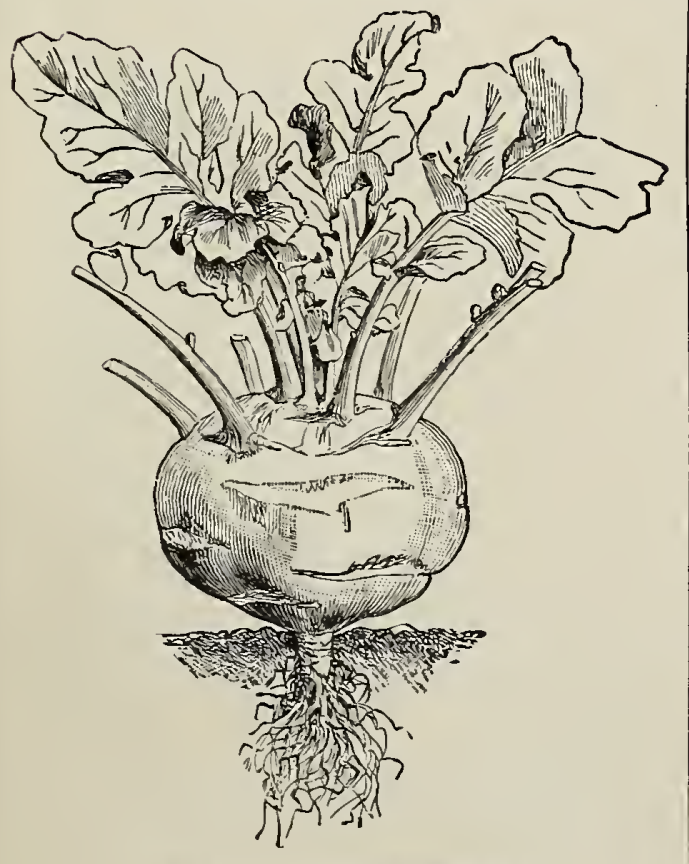

EARLY VIENNA KOHL-RABI

\section{Noll's Champion of All Lettuce}

The best all-around Lettuce for Spring and Fall planting. Introduced by us last season and it has proved to be a wonderful Lettuce in every locality. A sure header when other varieties fail. Color a beautiful light green. Pkt. 10c., oz. 25c., 1/4lb. 75c., Ib. $\$ 2.50$.

\section{HEAD VARIETIES} as large; desirable for Spring and Fall outdoor planting. \$0 10\$0 $20 \$ 050 \$ 1.50$ Boston Market. Very hardy and crisp; can be user for forcing $\ldots \ldots \ldots \ldots \ldots \ldots \ldots \ldots \ldots \ldots \ldots \ldots \ldots \ldots \ldots \ldots \ldots \ldots \ldots \ldots$

California Cream Butter. Tery large, solid heads, in-

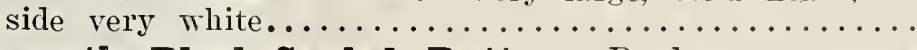

Mammoth Black-Seeded Butter. Produces enormous hearls, very tecder and crisp, for early Spring and Fall

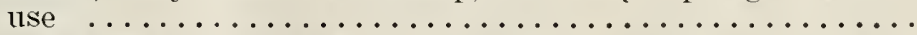

Yellow-Seeded Putter. A distinct jellow-hearled sort,

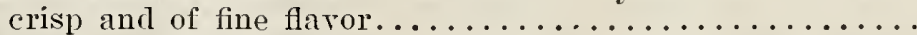

Deacon. Largely used for growing in cold frames; heads

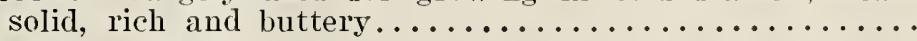

Grand Rapids. A free grower, rery curled and crumpled..

Hanson. Produces large hearls of fine quality ..........

Immensity. Especially adapted for late Summer and Fall

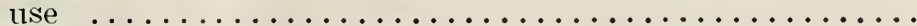

May King. Recommended as an early variety for sowing in the hotbed, and transplanted out in the open ground early

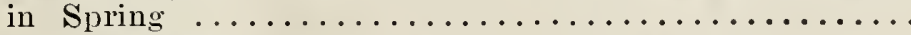

Magnum Bonum. Fine quality for all seasons, especially

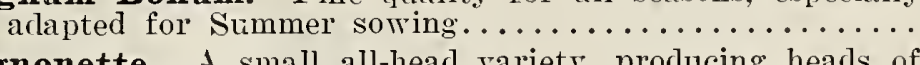

Mignonette. A small all-hearl variety, producing hearls of

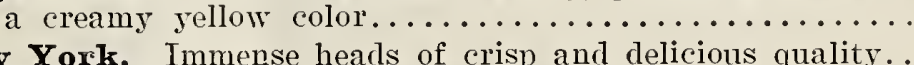

New Treasure. One of the best Summer varieties.........

Noll's Boston Glass House. A fine variety for forcing in the greenionse, making a good-sized hard head; seed we offer is especially grown by a market gardener, who

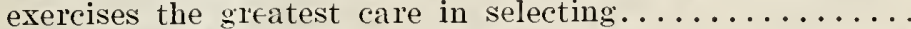

Salamander (Mammoth). Grows about double the size of Salamander; ove of the best for Summer use..........

Simon's Dutch Speckled Butter. A grand rariety for growing in the cold frames. It makes a large, white hearl, with a few brown spots on it; seed grown by a

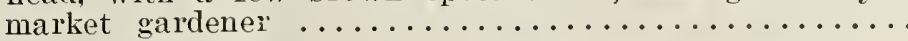

Summer Gem. One of the hardiest and surest heading rarieties of all Lettuces. Very raluable for Summer planting

$\begin{array}{llll}05 & 15 & 40 & 125 \\ 05 & 15 & 40 & 125 \\ 0.5 & 20 & 40 & 150 \\ 05 & 20 & 40 & 150 \\ 05 & 15 & 40 & 125 \\ 05 & 15 & 40 & 125 \\ 05 & 15 & 40 & 125 \\ 10 & 20 & 60 & 200 \\ 10 & 25 & 60 & 200 \\ 10 & 25 & 60 & 200 \\ 10 & 20 & 50 & 150 \\ 10 & 20 & 40 & 150 \\ 10 & 25 & 60 & 200 \\ 10 & & & \\ 10 & 50 & 150 & 500 \\ 10 & 25 & 60 & 200 \\ 10 & 20 & 75 & 250 \\ 10 & 60 & 200 \\ 15 & & & \\ 105 & & & \\ 105 & & & \\ 105 & 500\end{array}$

\section{CURLED or CUTTING VARIETIES}

Early Curled Simpson. Very early, largely grown in cold

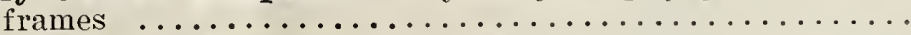

Black-Seeded Simpson. One of the best curled rarieties,

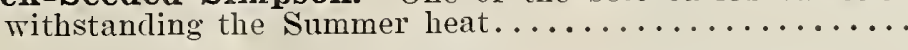

$\begin{array}{llll}0.5 & 15 & 40 & 125 \\ 0.5 & 15 & 40 & 125\end{array}$

\section{COS or ROMAINE}

Trianon Self-Closing. Very crisp and tender, producing leares stiff and crisp like Celerg . ................ 


\section{MUSKMELON "I \\ "MARYLAND"}

Considered by Expert Melon Growers Superior to the Best Strains of Rocky Ford
It is ten days earlier than the Rocky Ford, twice as productive and larger in size. The vines are of a strong. healthy growth, branch freely, setting a large number of fruits close to the hill. The melons are fine and regular in size and form, nearly round or slightly oval, and very closely netted. The skin is of a light golden hue when fully ripened. Flesh bright green, luscious in flavor and ripens close to the skin. Customer's who are fortunate enough to get some of this seed and who have been raising Rocky Ford melons will not grow them again after once planting this new strain. The stock is limited. Pkt. 10c., oz. 35c., 1/4 1b. $\$ 1.00,1 \mathrm{lb}$. $\$ 3.00$.

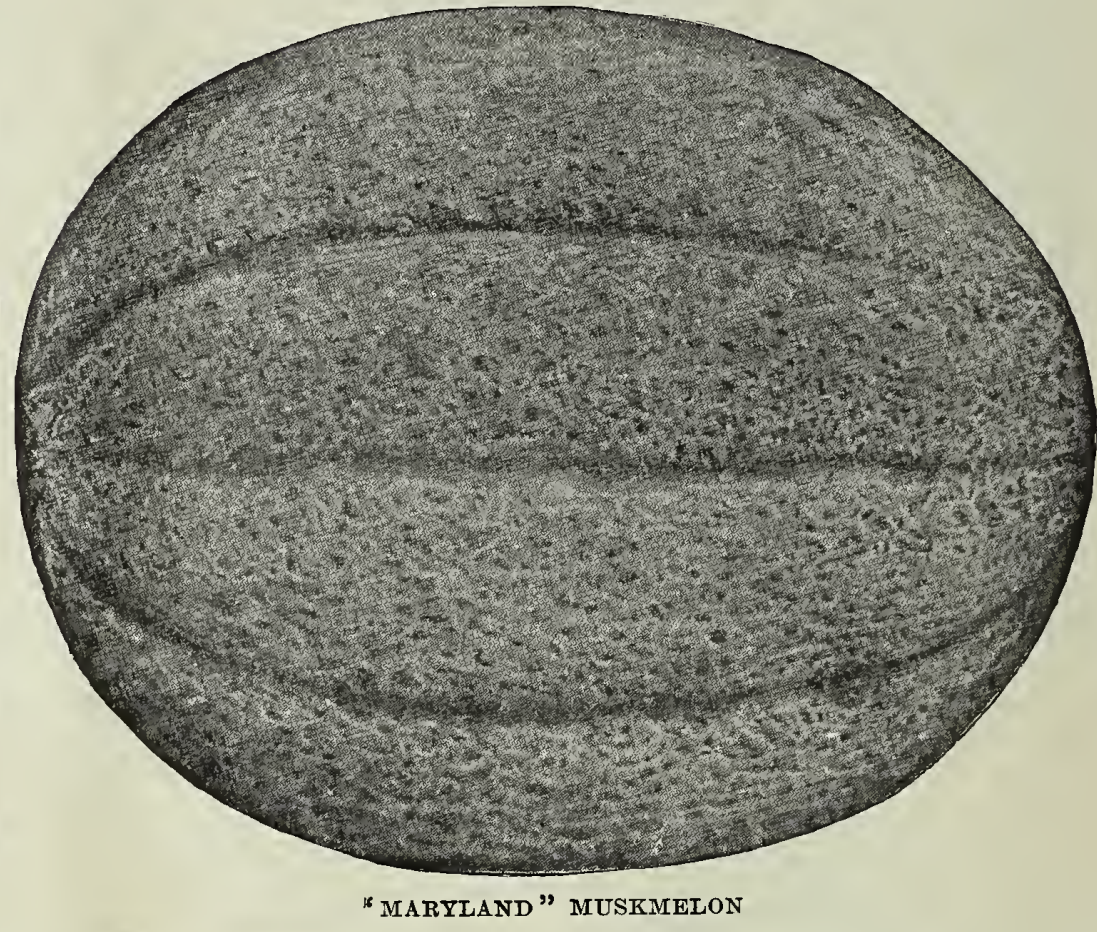

Burrell Gem. A new Rocky Ford with golden meat. Every trucker should try this variety, owing to Pkt. Oz. I/4 lb. Lb.

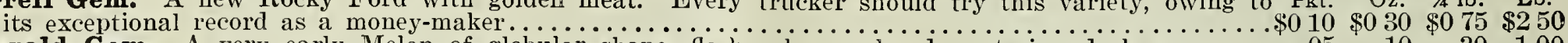
Emerald Gem. A very early Melon of globular shape, flesh salmon-colored; exterior dark green.... 05 Early Hackensack. A careful selection from Hackensack. Fruit much like it in shape and quality,

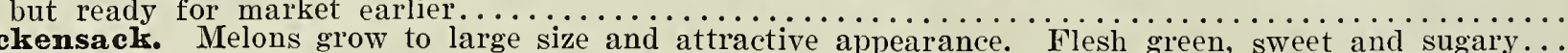
Hackensack. Melons grow to large size and attractive appearance. Flesh green, sweet and sugary...
Jenny Lind. The earliest variety, netted, of small, round size. Excellent flavor $\ldots \ldots \ldots \ldots \ldots \ldots \ldots$

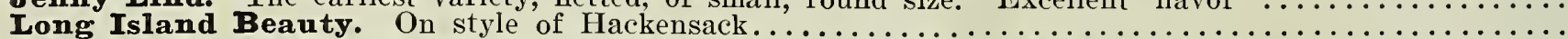

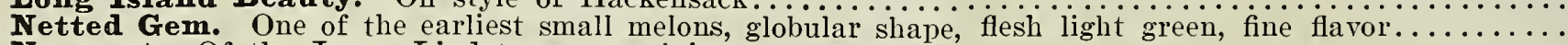

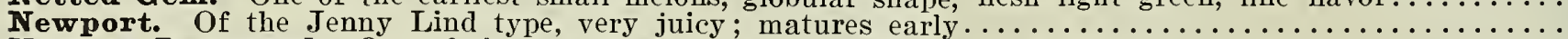

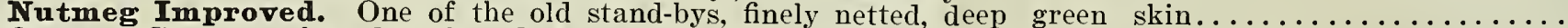

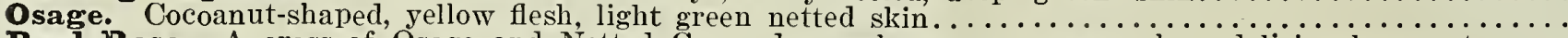

Paul Rose. A cross of Osage and Netted Gem; deep salmon or orange color; deliciously sweet.......

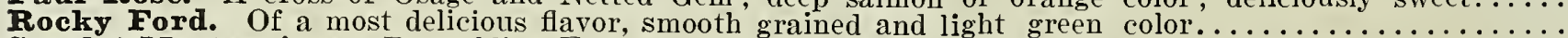

Scarlet Masterpiece. Resembling Emerald Gem, but almost double the size; a heavy cropper and a

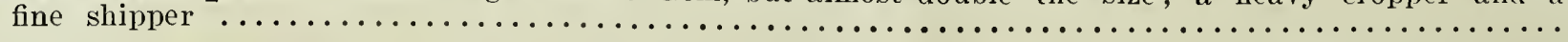

$\begin{array}{llll}10 & 15 & 30 & 100 \\ 10 & 15 & 30 & 100 \\ 05 & 10 & 30 & 100 \\ 05 & 10 & 30 & 100 \\ 05 & 10 & 30 & 100 \\ 05 & 10 & 30 & 100 \\ 05 & 10 & 30 & 100 \\ 05 & 10 & 30 & 100 \\ 05 & 10 & 30 & 100 \\ 05 & 10 & 30 & 100 \\ 10 & 15 & 30 & 100\end{array}$

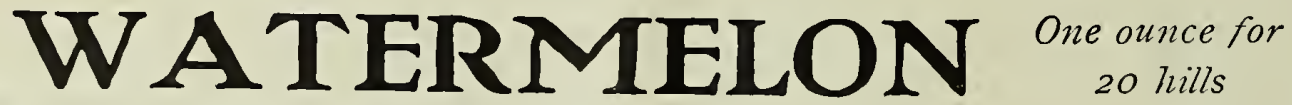

Black Diamond. Dark green, tough skin; large size, round

Cole's Eariy. Medium size, red flesh, green skin....

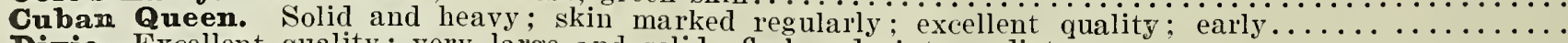

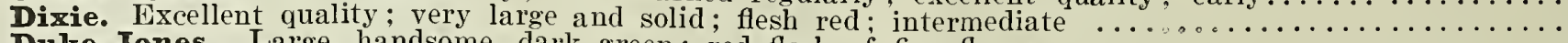

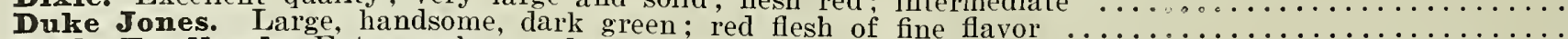

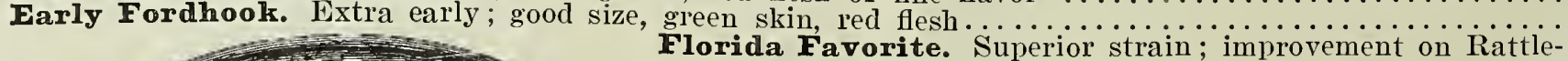

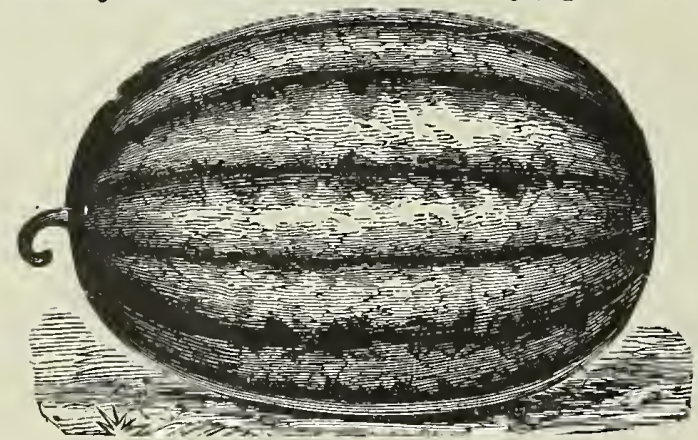

CUBAN QUEEN WATERMELON

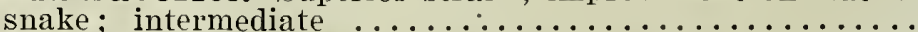

Ice Cream, White Seed. Very early; red flesh.........

Kleckley Sweets. Exceedingly sweet and fine-flavored, dark green skin, thin rind; flesh solid, scarlet and firm......

Kolb Gem. Large; good shipper; bright red flesh of fine

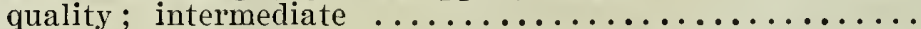

Mammoth Iron Clad. An old variety: grows to an immense size, oblong, dark green with light markings; red

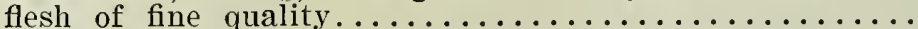

Mountain Sweet. Oblong, dark green fruits, rind thin;

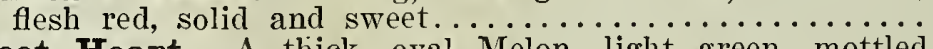

Sweet Heart. A thick, oval Melon, light green, mottled with thin tough rind; flesh light red, solid, of fine quality

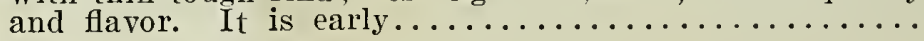

Pkt. Oz. $\quad 1 / 4 \mathrm{lb}$. Lb. $\$ 005 \$ 010 \$ 020 \$ 050$ $\begin{array}{llll}0.5 & 10 & 25 & 70\end{array}$ $\begin{array}{llll}05 & 10 & 20 & 60\end{array}$ $\begin{array}{llll}05 & 10 & 20 & 60\end{array}$ 


\section{Noll's Sure Crop American}

\section{Mushroom Spawn}

Mushrooms mar be gromn br ansone haring a supply of fresh horse manure and a tight shed or cellar, or under a greenhouse bench where a temperature of 50 or 60 degrees can be evenl maintained. Thes are a most profitable crop when successfully gromn, and the American market is the best in the norld for this most delicious of foods. It comes in bricks weighing about 11/4 lbs.; enough to plant a bed about 9 square feet. Lb. 15 c., 100 Ibs. \$12.00.

\section{MUSTARD}

\section{1 oz. will sow about is feet of drill}

Southern Giant Curled. Highly esteemed in the South, where the seed is sown in the Fall, and used in the Spring as a salad. Pkt. Jc., oz. 10c., $1 / 4$ lb. 20c., 1b. 60c.

New Chinese. Leares trice the size of the ordinary Thite Mustard, crimpled like a Saго cabbage; stems more succulent; flavor pleasantly sweet and pungent. Pkt. כ̌c., oz.

White London. The old sort, used for salads and flaroring. Oz. 5ैc., $1 / 4$ lb. 15c., 1b. 35c.

\section{NASTURTIUM - Indian Cress}

Tall. The best for pickling seed pods, or garnishing. Pkt. 5c., oz. 10c., 1/4 lb. 20c., 1b. 60c.

Dwarf Mixed. i trailer requiring no support. Pkt. 5c., oz. 10c., 1/4 lb. 20c., 1b. 65c

\section{OKRA, or GUMBO}

The pods sliced are esteemed for soups, stens, etc., and, whether used green or dried, must be gathered when roung.

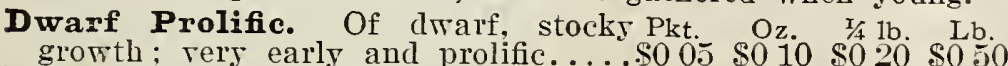
growth; rery early and prolific..... \$005 $\$ 010 \$ 020 \$ 050$ Long Green. Long, slender, pale

Perkins' Mammoth Long-Podded. $\begin{array}{llll}05 & 10 & 20 & 50\end{array}$ Very prolific; most desirable for can-
ning $\ldots \ldots \ldots \ldots \ldots \ldots \ldots \ldots \ldots \ldots$

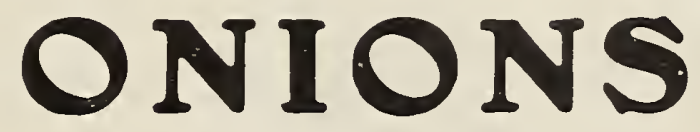

One ounce to too feet of drill

\section{$\underset{\text { Grown }}{\text { American }}$ Prize-Taker Onion}

Grows Bulbs Weighing One Pound First Year From Seed. The Grandest Variety Grown. Excels in Yield, Size and Keeping Qualities.

The Prize-taker Onion has now heen several years on the market, and is recognized as one of our best standard rarieties. Rarely has any vegetable attained prominence more rapidly; it succeeds everywhere-East, West, North and South-and
whether grown for home use or for marketing it gices unirersal satisfaction, zielding onions often 14 inches around and at the rate of 1,200 to 1,500 bushels per acre-often much more under exceptionalls good culture. Its immense size and mildness of flaror delight everrone who raises it. Nothing short of actual knowledge of this rariets will conrey a really adequate idea of its great ralue, whether considered as a rariety for commercial or prirate culture. Its immense size will recommend it to all, particularls when it is known that its keeping qualities are unexcelled. The exterior is pale sellow, and the interior clear sparkling, white. It is easily grown, medium early in maturing, mild in flaror. By sowing early in a sheltered spot and transplanting the joung plants, it can be grown to an immense size. Pkt. 5c., oz. 25 c., $1 / 4$ 1b. 60c., 1b. $\$ 2.00$.

\section{Larǵe Red Wethersfield Onion}

A Iéading Variety. Produces Enormous Crops of Solid, Heavy and Perfect Onions.

Large Red Trethersfield is a grand red rariets and a general farorite. With the exception of the Fellow Globe Danrers, there is no rariety so largely grown. Our stock is excellent, being sared from only carefully selected bulbs. Our stock will be found quite free from necky and misshapen bulbs, and will invariably grow to a large size under proper conditions. The surface color is a rich dark red. It is an earls rariety to mature and a fine keeper. The flaror is good and mild and it is 50c., 1b. $\$ 1.75$.
Pkt. 5c., oz. 15c., 1/1 1b. 


\section{ONIONS-Continued}

\section{Southport G L O B ES}

Perfect Globe Shape, Large, Heavy and Solid $\$ * *$

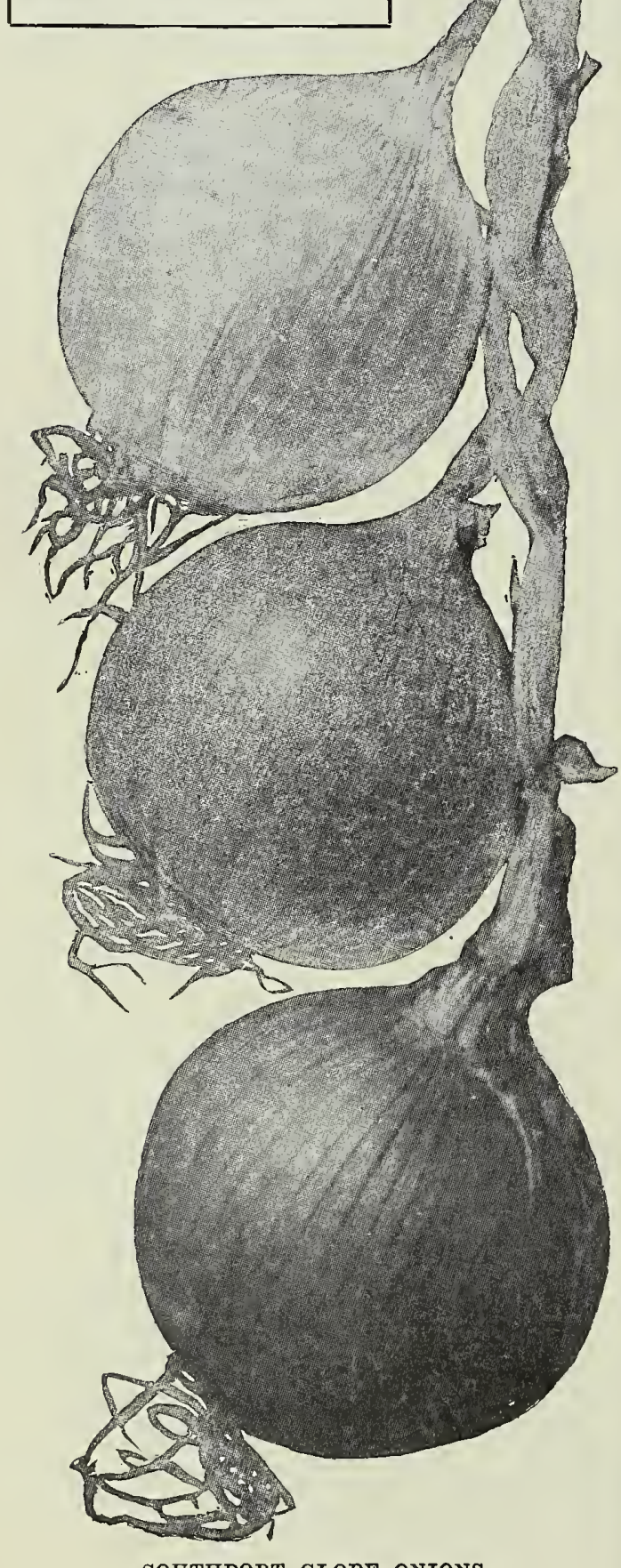

SOUTHPORT GLOBE ONIONS

\section{SOUTHPORT RED GLOBE}

An early-maturing, large-sized, globe-shaped Onion, with deep red skin. Flesh fine-grained, very wild and tender. Pkt. 5c., oz. 20c., 1/4 1b. 60c., 1b. $\$ \mathbf{2 . 0 0}$.

\section{SOUTHPORT WHITE GLOBE}

An enormous yielder and superb keeper. Perfect globe-shaped, very large, clear white skin and considered one of the handsomest varieties grown. The crop of this rariety was practically a failure last season, but we have obtained a very limited supply of the very finest stock obtainable. Pkt. 10c., oz. 30c., 1/4 1b. $\$ 1.00$, 1b. $\$ 3.00$.

\section{SOUTHPORT YELLOW GLOBE}

A fine variety for market gardeners. A great cropper of handsome large globe-shaped Onions, with clear yellow skin. Pkt. 5c., oz. 25c., 1/4 1b. 75c., 1b. $\$ \mathbf{2 . 0 0}$.

Extra Early Red Flat. A very early, round Lat Onion, thriving well in cool soil....................\$0 $05 \$ 020 \$ 045 \$ 175$

Michigan Ohio Yellow Globe. Yields largest crop of any Yellow Onion; uniform in shape; attractive color.

Noll's Improved Yellow Globe Danvers. A decided improvement on Yellow Globe Danvers, owing to its perfect, uniform shape, without neck, larger and of a

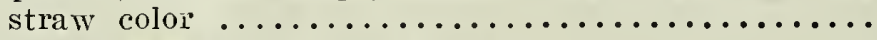

Red Wethersfield. (See page 21.)

Round Yellow Danvers. Grown extensively for market, also popular for Onion Sets; ripens more surely in moist soils than the Globe-shaped variety.........

White Portugal, or Silvex Skin. A specially selected sure-ripening strain of the Silver Skin, which is largely

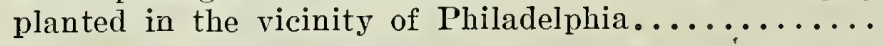

Extra Early White Bunch. Especially adapted for using when young, or bunching for sale; produces a showy, white, large Onion, of mild flavor...........

Yellow Dutch, or Strasburg. One of the best yellow varieties to grow sets.................. $05 \quad 20 \quad 40 \quad 150$

\section{Italian, and Pickling Varieties}

Adriatic Barletta. Extremely early; small, pure white, flesh mild; unexcelled for pickling.................

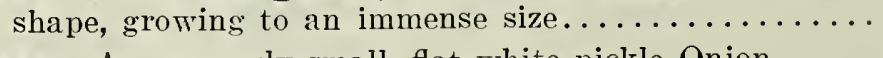
Queen. A very early small, flat white pickle Onion......
White Dutch, or Hard Round Silvex Skin. One

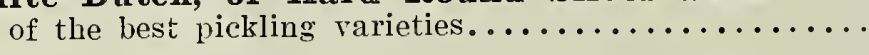

$\begin{array}{llll}05 & 20 & 45 & 175 \\ 05 & 20 & 60 & 200 \\ & & & \\ 05 & 20 & 60 & 200 \\ 10 & 20 & 75 & 250 \\ & & & \\ 05 & 25 & 60 & 200 \\ 05 & 20 & 40 & 150 \\ & & & \\ 10 & 25 & 75 & 250 \\ 10 & 25 & 75 & 250 \\ 05 & 25 & 60 & 200 \\ 10 & 25 & 75 & 250\end{array}$

\section{ONION SETS}

Red Onion Sets...

Qt. Pk. Bus.

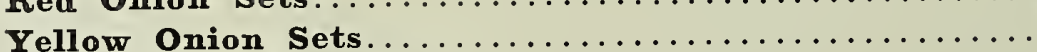

$25 \$ 125 \$ 400$

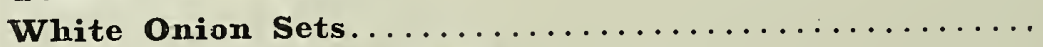

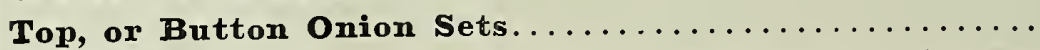

Shallots. The small bulb keeps for a year; esteemed for sea-

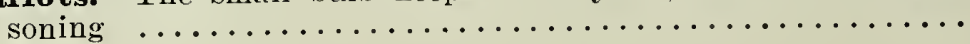

$25 \quad 125 \quad 400$

$\begin{array}{lll}30 & 140 & 450\end{array}$

$25 \quad 140 \quad 450$

$25150 \quad 500$ 


\section{Parsley, Parsnip, Pepper}

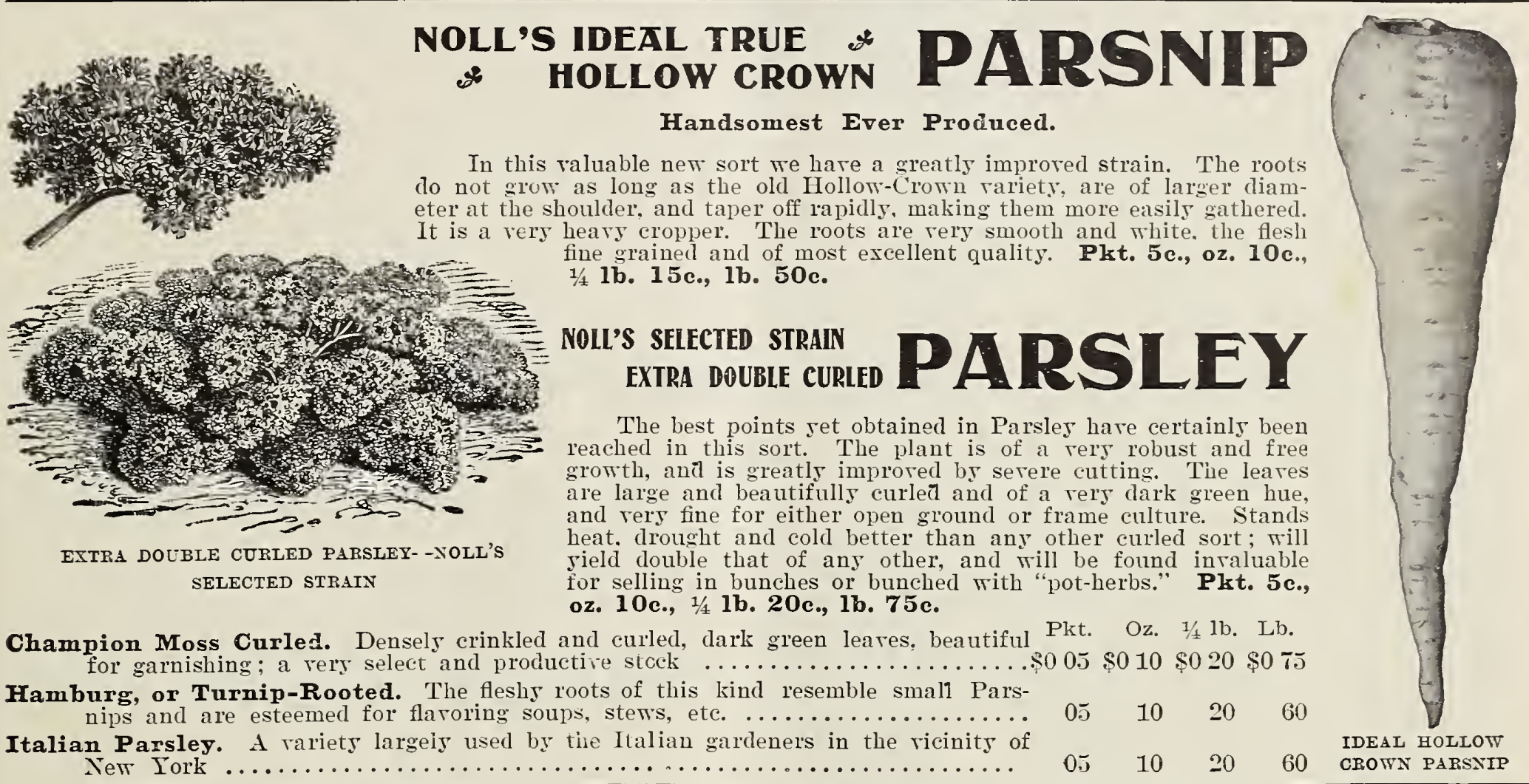

\section{RUBY GIANT PEPPER $\begin{gathered}\text { One ounce produces } \\ \text { rooo plants }\end{gathered}$}

In Philadelphia and many other markets there is a demand for long-shaped Peppers in the strle of the Ruby King. To meet this demand a New Jerser grower has successfully crossed the Ruby King and Chinese Giant with the longer shape of the

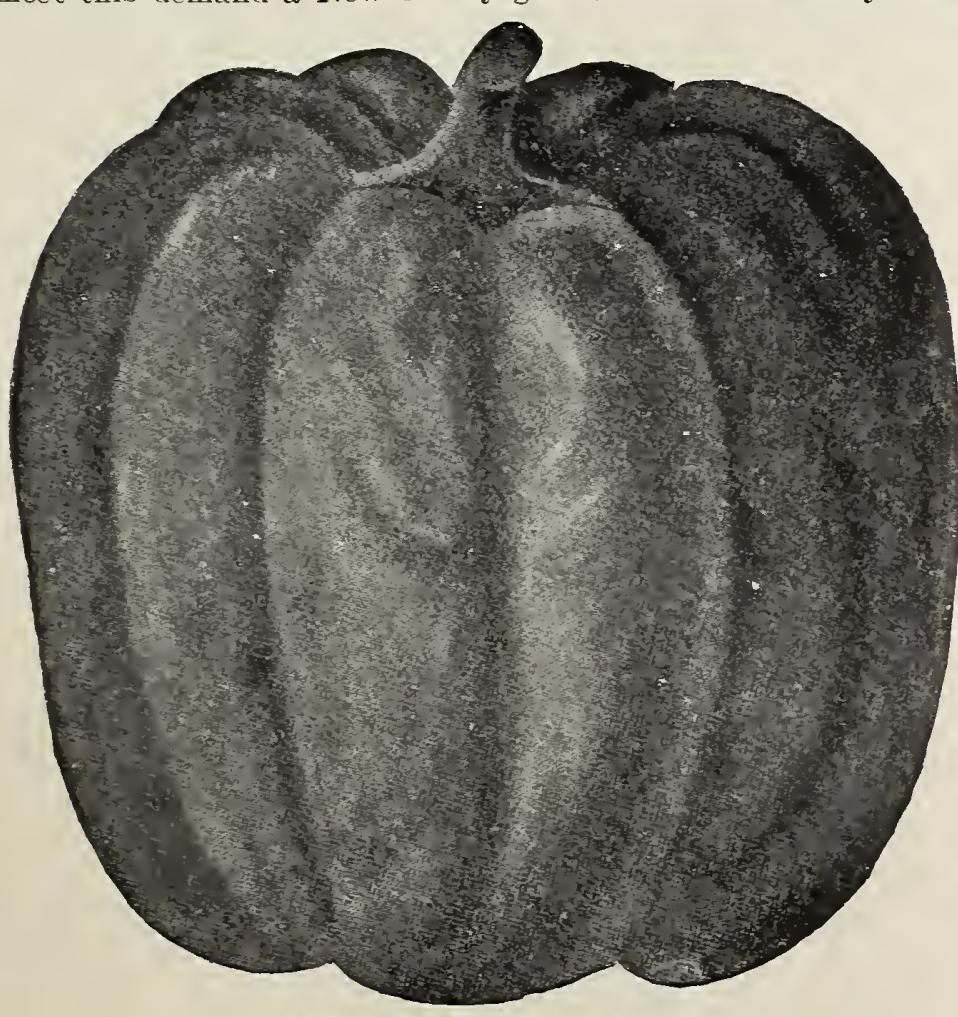

NEW CHINESE GIANT PEPPER
Ruby King. It is unexcelled for stuffing. and its size and appearance almars command the top market prices. Pkt. 10c. oz. 30c., $1 / 4$ lb. 90 c., lb. $\$ 3.00$.

Chinese Giant. Cnđoubtedly the largest street Pepper ever offered. The flesh is thick, mild and sweet.............\$0 $10 \$ 040 \$ 125 \$ 450$

Crimson Giant. In shape it is similar to Chinese Giant. It does not grow quite as large as Chinese Giant but is a heavier cropper. Flesh is rers thick and sweet. The quantity of seed we have of this rariety is limited.........

Golden Dawn. A mild and sweet rellow Fepper, rery attractive.............

Large Bell, or Bull Nose. Large early rarietr, thick and fleshr. greatl $\Gamma$ used for pickling and mangoes, when green.

Iong Red Cayenne. The pods are long and slender, of a bright red color and rery pungent, extensirely used for bunching with pot-herbs............

Red Chili. Generally used for making pepier sauce, small bright red, very hot.

Ruby King. An excellent rariety for pickling, rery productire...........

Neapolitan. Ten dars earliel than ans other variety, fruits grow to a good size.

Sweet Mountain. Nearls the same as the Bull Nose. large in size and of deeper shape, mild in flaror..........

$\begin{array}{llll}10 & 50 & 1.50 & 5.00\end{array}$

$0.5 \quad 25 \quad 75 \quad 250$

$0.5 \quad 25 \quad 75 \quad 250$

$0.5 \quad 2.5 \quad 75 \quad 250$

$\begin{array}{llll}05 & 25 & 75 & 250\end{array}$

$05 \quad 25 \quad 100 \quad 350$

$1035 \quad 100 \quad 400$

$0.5 \quad 25 \quad 75 \quad 250$ 


\section{Noll's Grand Monarch Pea}

Surpassing in earliness, yield and quality, the popular Gradus or Prosperity

A variety for the Gardener to grow

Produces quantities of large pods full of luscious peas. The vines grow from $21 / 2$ to 3 teet in height, The pods which are as large as Telephone are produced in abundance filled with from six to ten peas of large size. Can be sowed earlier than any of the early large varieties owing to the hardiness of the seed. $1 / 2$ pt. IOc., pt. 15c., qt. 25c., pk. $\$ 1.75$, bush. $\$ 6.50$.

\section{NOLL'S SELECTED
EXTRA EARLY \\ PEA}

For extra earliness, and a pea to withstand greater change of weather, we know of no variety that is superior, earlier, or gives gardeners more profit than this variety. Pods are well filled, of a deep green color, and can be shipped . long distances. 1/2 pt. 10c., Pt. 15c., qt. 25c., pk. $\$ 1.50$, bush. $\$ 5.00$.

\section{DUKE OF ALBANY PEA}

\section{(American Champion)}

It is one of the largest of all peas, enormously productive and its flavor and quality closely approach that of the well-known Champion of England. The pods are produced in pairs and are well filled. Each pod contains from nine to twelve large, fine peas. It is a tall-growing sort of branching habit; it should be sown thinly. Height four and a half feet. $1 / 2$ pt. 10c., qt. 25c., pk. \$1.50, bush. \$5.00.

GRAND MONaRCH PEA

\section{Sutton's Excelsior Pea}

One of the finest sorts of recent introduction. The pods are the size of Gradus, but are broader and filled with from 8 to 10 peas. The habit of the vine is similar to Nott's Excelsior, being about the same height. Can be picked the same time as Gradus. $1 / 2$ pt. 15c., pt. 25c., qt. 40 c., pk. $\$ 2.00$., bush. $\$ \mathbf{\$ 7 0}$.

\section{Prosperity. or Gradus Pea}

A great Extra Early Wrinkled Pea. This remarkable pea is not only laige and of the best quality, but it is nearly quite as early as the small, round extra-early sorts. It is sold under two names, but the two strains appear to be identical. Gradus is a wrinkled pea, with vine groving about 30 inches high. The pods are of a bright green color, and measure four inches or more in length, being as large as Telephone, filled with luscious peas-eight to ten or more in a pod The peas are a first-class table quality and retain their color and attractive appearance after cooking. 1/2 pt. 10c., pt. 20c., qt. 30c., pk. $\$ 2.00$, bush. $\$ 7.50$.

\section{Nott's Excelsior Pea}

The most valuable of all dwarf early wrinkled peas

Surpassing in earliness, yield and quality

This is an extra early dwarf wrinkled pea, usually ready for table in 40 to 45 days from planting, only a few days later than the early round sorts. It grows about 14 inches high, or about half as tall again as the American Wonder. It is of vigorous constitution, and wonderfully productive. $1 / 2$ pt. 10c., pt. 15c., qt. 25c., pk. \$1.60, bush. $\$ 6.00$.

\section{McLean's Advancer Pea}

A second early variety, attaining a height of $2 \frac{1}{2}$ feet, a great favorite with growers in this neighborhood, among whom it is often known as the Dwart Champion. It is a green wrinkled variety of fine flavor. $1 / 2$ pt. 10c., pt. 15c., qt. 25c., pk. \$1.25, bush. $\mathbf{\$ 4 . 0 0}$. 


\section{DWARF EXTRA EARLY VARIETIES}

American Wonder. A rery fine extra early wrinkled variety, rell suited for the private garden; flaror and quality excellent. Height 1 foot......\$0 10 \$0 1.5 \$0 2.5 \$1 60\$600

Iittle Gem. A dmarf, first early green wrinkled

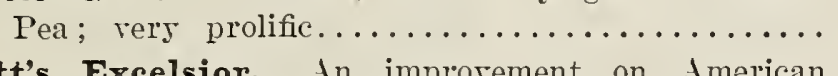

Nott's Excelsior. An improrement on American Tonder; pods larger and more of them; extra fine qualits $\ldots \ldots \ldots \ldots \ldots \ldots \ldots \ldots \ldots \ldots \ldots \ldots \ldots \ldots \ldots \ldots \ldots \ldots$

Premium Gen. Of rery fine flaror and an improve-

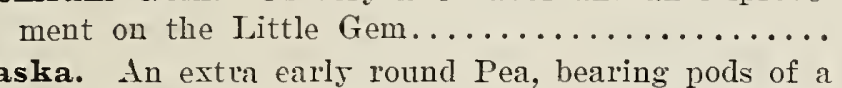

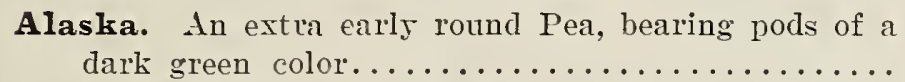

Daniel O'Rourke, Improved. One of the earliest and most prolific round smooth white Peas.......

First of All. Good early sort................

Noll's Selected Extra Early. One picking will take about three-quarters of a crop; second picking about three dass later will take the balance....

Noll's Grand Mowarch. (See page 2'.)

Thomas Laxton. A new variety of large-podded Pea; will mature nearly as early as the Extra

Early Smooth Peas..............................
Prosperity. Combining the finest quality with extreme earliness; grows about $2 \frac{1 / 2}{2}$ feet............. $10 \quad 20 \quad 30 \quad 200 \quad 750$

\section{SECOND EARLY or MEDIUM VARIETIES}

Advancer. (See page 24.)

Heroine. A medium early rariety, showr pods and an immense crcpper; fine quality............. ducing long, handsome, well-filled pods..........
Shropshire Hero, Grows about three feet tall, pro-

$\begin{array}{lllll}10 & 15 & 25 & 160 & 600 \\ 10 & 15 & 25 & 160 & 600 \\ 10 & 15 & 25 & 175 & 650 \\ 10 & 15 & 25 & 160 & 600 \\ 10 & 15 & 25 & 100 & 350 \\ 10 & 15 & 25 & 100 & 350 \\ 10 & 15 & 25 & 150 & 500 \\ & & & & \\ 10 & 20 & 50 & 175 & 650 \\ 10 & 20 & 30 & 200 & 750\end{array}$

$\begin{array}{lllll}10 & 15 & 25 & 150 & 500 \\ 10 & 15 & 25 & 150 & 500\end{array}$

\section{MAIN CROP or LATE VARIETIES}

American Champion, or Duke of Albany. A grand large-podded wrinkled rariets, producing

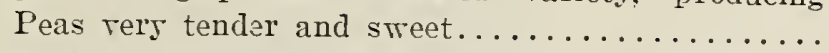

Champion of England. A popular rrinkled rariety of delicious flaror; peas are large and very

Juno. Large straight pods, borne in pairs and filled with delicious dark green peas of fine flaror......

Telephone. Immensely productice; rines strong, producing large pods which are of a pale green color..

Black-Eyed Marrowfat. Extensirely grown as field

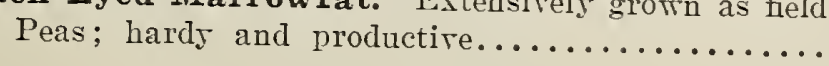

\section{PEAS, EDIBLE PODS}

Melting Sugar. Pods grow five to six inches long, and are entirely stringless and very tender....... 10

For Field and Cow Peas, see page 35.

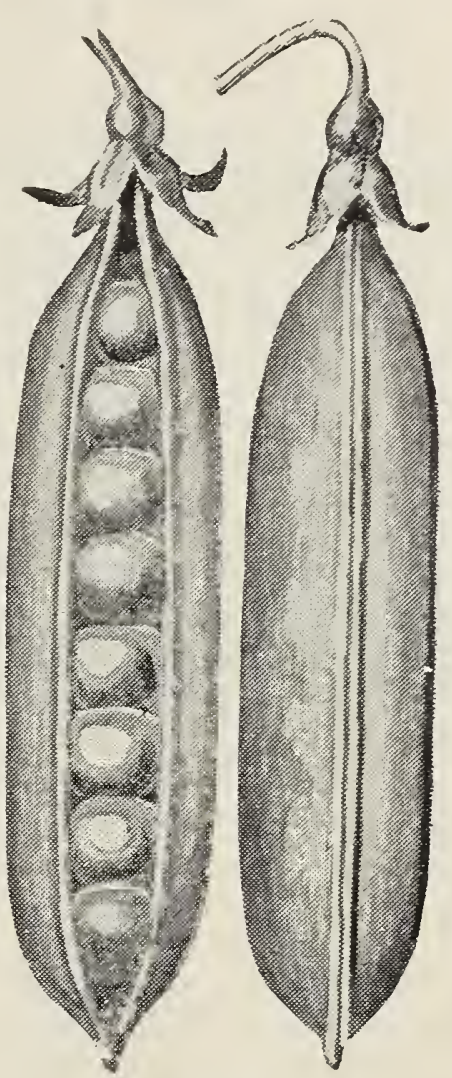

NOTT'S EXCELSIOR PEA
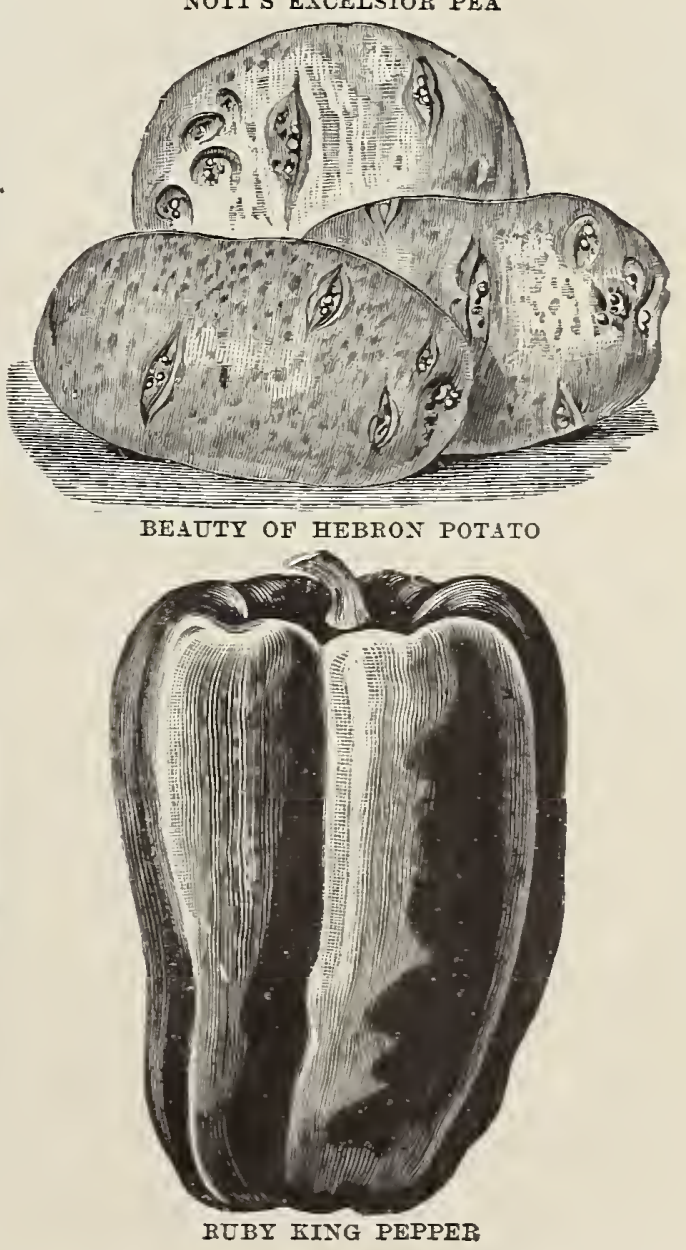


\section{PUMPKIN}

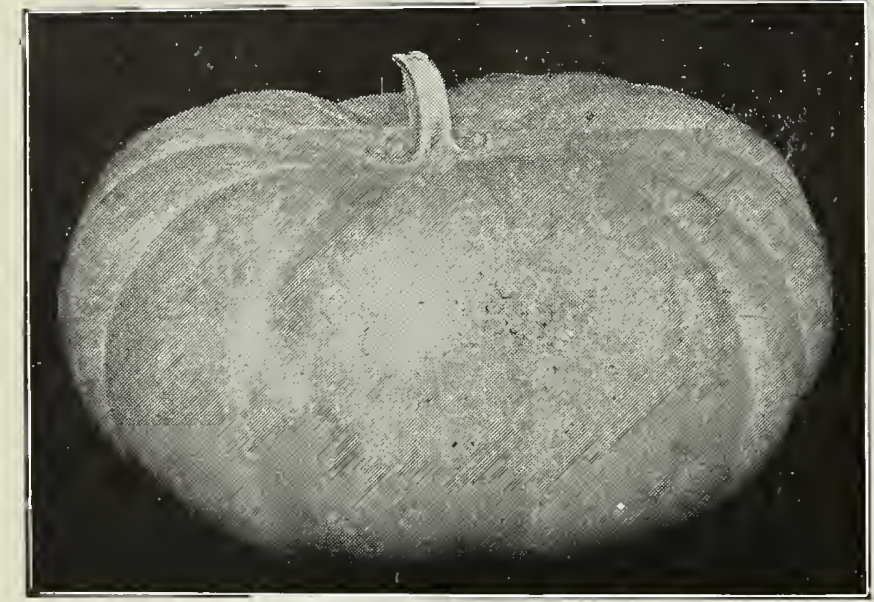

LARGE CHEESE PUMPKIN

\section{Large Sweet Cheese or Kentucky Field....}

A most popular variety. Fruit flattened, skin mottled light green and yellow, changing to rich cream color as it matures. Flesh yellow, thick, tender, very nutritious and of excellent quality ; a most productive variety. Pkt. 5 c., oz. 10c., $1 / 4$ 1b. 15c., 1b. 50c.

Calhoun. A round Pumpkin of the finest qual- Pkt. Oz. $1 / 41 \mathrm{lb}$. Lb. ity, flesh deep salmon yellow, fine grained...\$0 $\$ 5 \$ 010 \$ 025 \$ 075$ Connecticut Field. One of the most productive field Pumpkins, mostly used for feeding

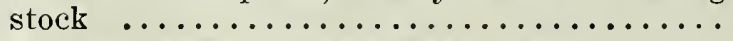

Jumbo, or King of the Irammoth. Specimens have been grown weighing over 190 pounds. The color of the outer skin is a rich dark yellow, flesh a little lighter shade. .

Large, or Mammoth Tours. Very productive

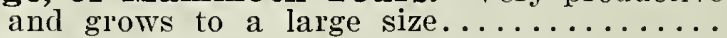

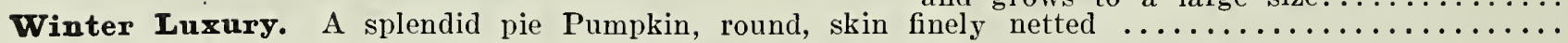

$\begin{array}{rrrr} & 05 & 10 & 30 \\ & & & \\ 10 & 15 & 35 & 100 \\ 05 & 10 & 20 & 60 \\ 05 & 15 & 30 & 100\end{array}$

Bovee. Earlier than Early Rose and a much more productive variety. The skin is pink, grows very

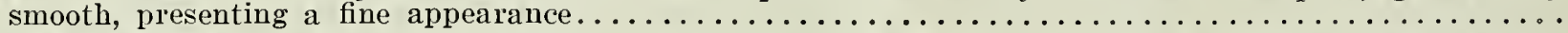
Beauty of Hebron. An old-time favorite of good size and excellent quality; a remarkably good keeper. Early Ohio. Matures early, and are fit for use before fully ripe; very popular, early market variety Early Norther. Similar to the Early Rose, but earlier; very prolific, fine cooking quality..........

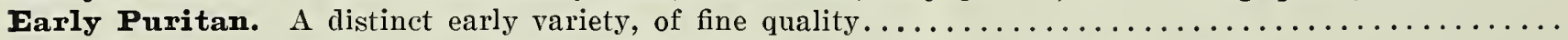

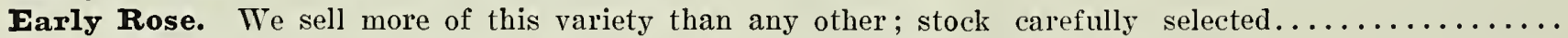

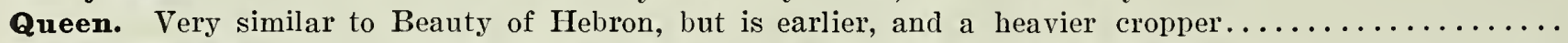
Green Mountain. A roundish flat, smooth white variety, suitable for mid-season; very heavy cropper. Sir Walter Raleigh. Grow to a large size, heavy cropper, flesh white and fine grain...........

Prices of

\section{Potatoes}

Quoted $U_{\text {pon }}$

Application

\section{Noll's Selected Strain, Scarlet Turnip White Tipped RADISH}

Very popular for outdoor culture and growing in frames. Medium size, bright scarlet color with a distinct white tip. Matures in 28 days. Pkt. 5c., oz. 10c., $1 / 4$ 1b. 15c., 1b. 50c., 10 lbs. 35c., 100 lbs. $\$ 30.00$, 25 lbs. sold at 100 lb. rate.

\section{BRIGHT RED FORCING GLOBE RADISH}

This is Unquestionably the Best Red Forcing Variety for Growing Under Glass; Also Very Desirable for Outdoor Planting.

It is of a brilliant scarlet color, with very short and small leaves, tender, crisp, and in quality all that could be desired. Will mature in 25 days and can be grown very thickly in the row; unlike other sorts, it sells well throughout the year. Should be pulled when not more than two-thirds grown. Pkt. 5c., oz. 10c., $1 / 4$ 1b. 20c., 1b. 60c., 5 lbs. \$2.75.

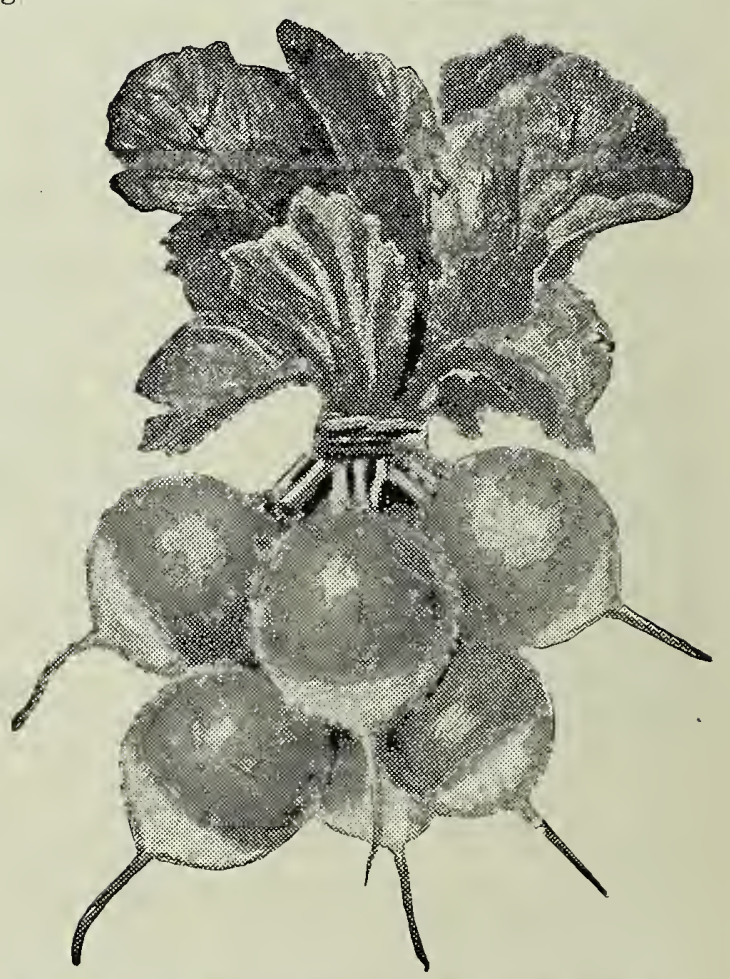

EARLY SCARLET TURNIP WHITE TIPPED RADISH 


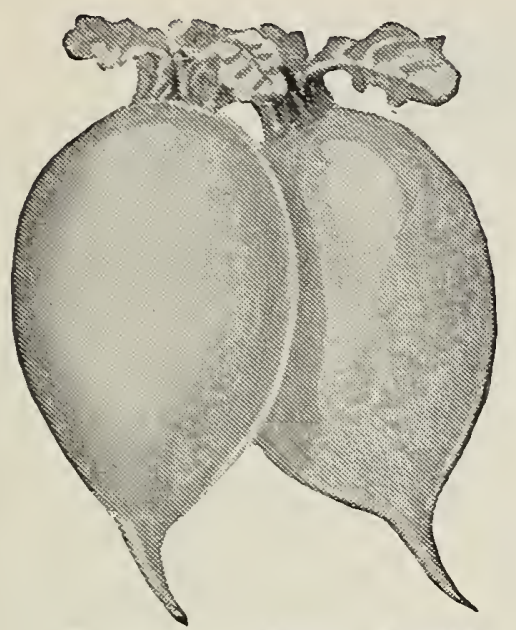

OLIVE-SHAPED YELLOW RADISH

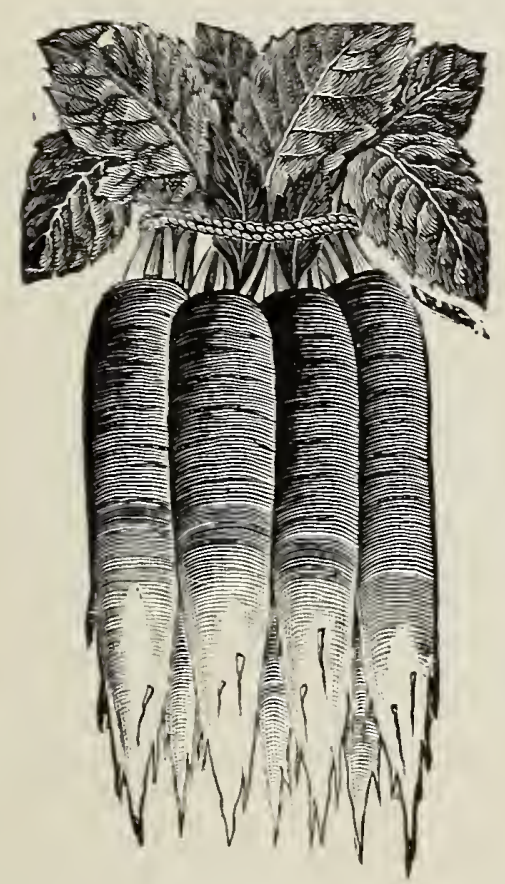

CHARTIER RADISE

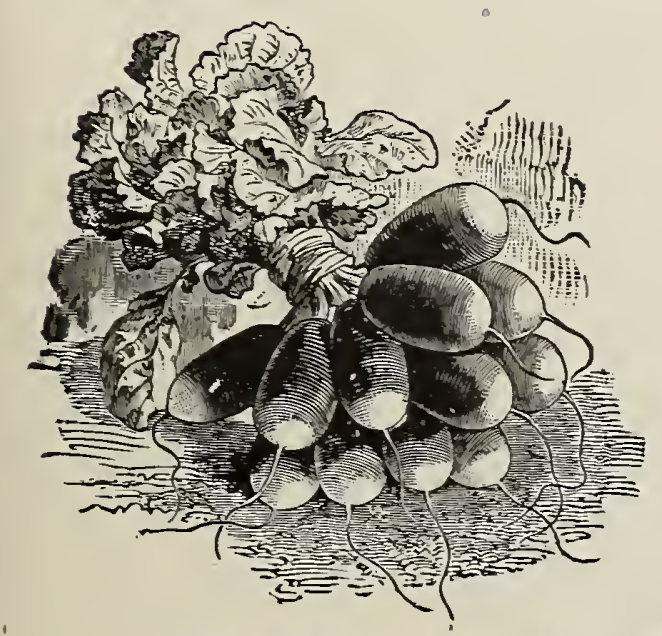

FRENCH BREAKFAST RADISB

\section{RADISH-Continued_I ounce for roo feet of drill}

\section{WHITE * ICICLE

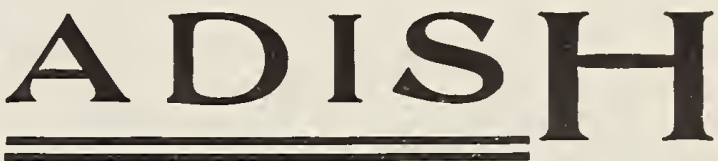

The finest rery early pure white Radish. Planted in Spring, is ready for use in in 20 to 2.5 days. This Radish is not only crisp and tender when young but retains these qualities until the roots attain larger size. Excellent for forcing. Pkt. 5c., oz. 10c., 1/4lb. 25 c., 1b. 75 c.

\section{Noll's Slected Straing : BLACK RADISH}

A very desirable Radish for late Summer and Fall use.

The flesh is white. crisp and tender; of quick growth, and stands the heat well. Pkt. 5c., oz. 10c., 1/41b. 25c., 1b. 75 c.

Bright Red Forcing Globe. (See page 26.)

Pkt. Oz. I/2 lb. Lb.

Early Scarlet Turnip. Medium size, quick grower, bright scarlet color ..................................... $05 \$ 010 \$ 015 \$ 050$

Crimson Giant. Globular in shape, and of a most brilliant cardinal red color, for either open ground or forcing... $\quad \begin{array}{lllll}10 & 15 & 25 & \text { 7. }\end{array}$

Early White Box. A very early round. white variety: used extensively in Philadelphia........................ $055^{10} 15$

Early White-Tipped Scarlet Turnip. (sce page 26.)

Scarlet Globe. A dainty Radish, of mild flavor: bright red,

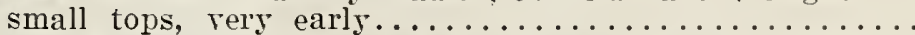

French Breakfast. Oblong shape, scarlet color, tip white. Olive-Shaped Scarlet. A half-long. oral-shaped rariets;

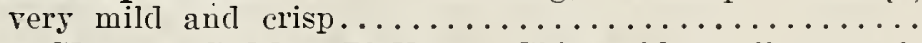

Olive-Shaped Golden Yellow. Skin golden sellow, oral-

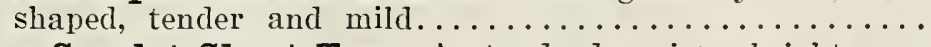

Long Scarlet Short Top. A standard rariets, bright scar-

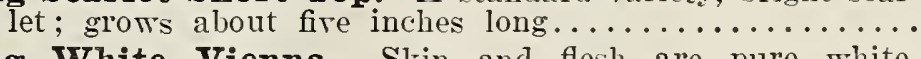

Long White Vienna. Skin and flesh are pure white.

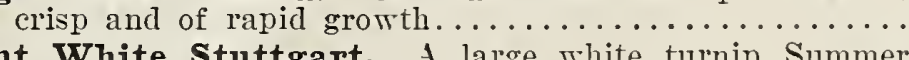

Giant White Stuttgart. A large white turnip Summer

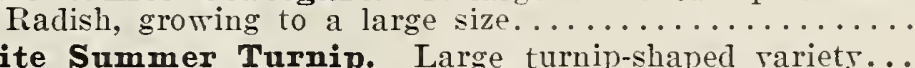

White Summer Turnip. Large turnip-shaped rariets...
Yellow Summer Turnip. A round, bronzs sellow Radish, rery much in faror in the New York markets.........

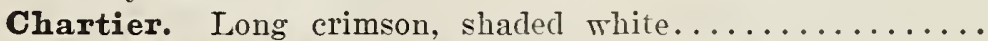

White Strasburg. Roots oblong, pure white, mild flaror. . Celestial, or White Chinese. A large, white Radish,

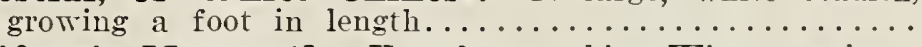

California Mammoth. Very large, white, Tinter rariets.

Rose China Winter. Bright rose color; flesh firm, about

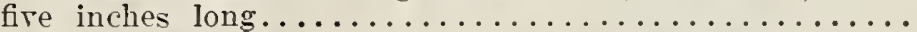

Long Black Spanish. One of the heartiest, and best for

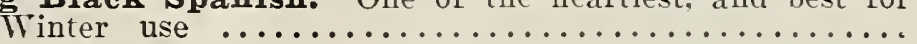

\section{RHUBARB}

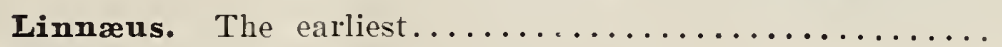

Roots. Strong .............Each 15., doz., \$1.50.

$\begin{array}{llll}05 & 10 & 15 & 50 \\ 05 & 10 & 20 & 50 \\ 05 & 10 & 20 & 50 \\ 05 & 10 & 20 & 60 \\ 05 & 10 & 20 & 50 \\ 05 & 10 & 20 & 50 \\ 05 & 10 & 20 & 50 \\ 05 & 10 & 15 & 50 \\ 05 & 10 & 15 & 50 \\ 05 & 10 & 15 & 50 \\ 05 & 10 & 15 & 50 \\ 05 & 10 & 25 & 75 \\ 05 & 10 & 20 & 60 \\ 05 & 10 & 20 & 50 \\ 05 & 10 & 20 & 60\end{array}$

$05 \quad 20 \quad 50 \quad 150$ 


\section{New Giant White French

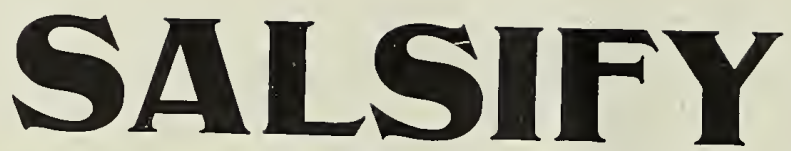

The Largest, Smoothesi and Most Profitable in Cultivation

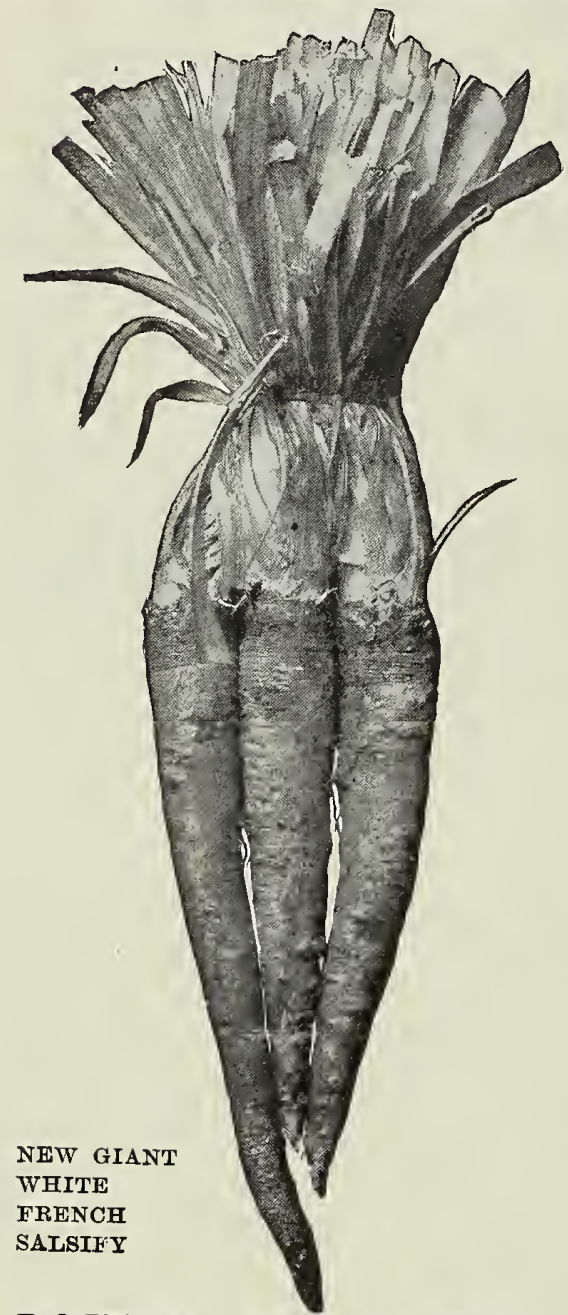

BOSTON SQUASH

A popular second early Squash for Autumn use; skin thin, reddish yellow; flesh dry, fine grained and delicious. Pkt. 5c., oz. ] Oc., $1 / 4$ 1b. 20c., 1b. $75 \mathrm{c}$.

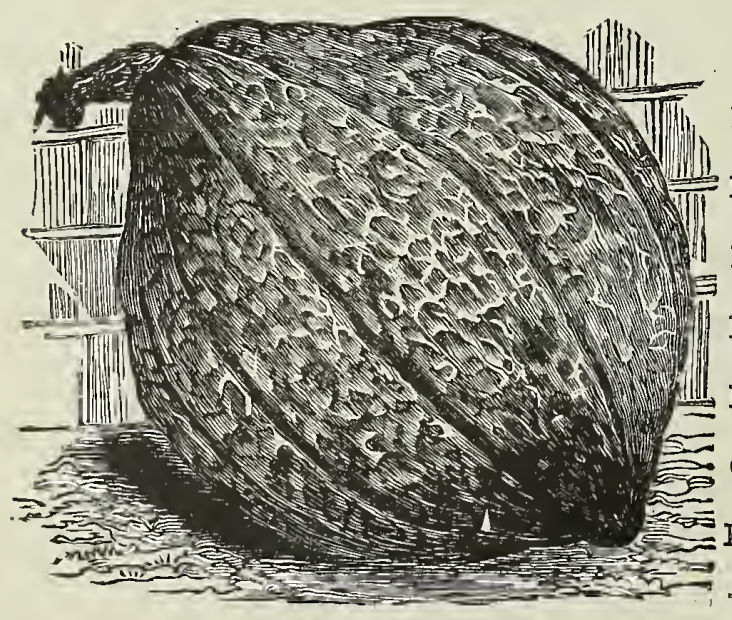

BOSTON MARROW SQUASH
The roots are pure white, much larger than the Mammoth Sandwich Island Salsify. The flesh is finegrained, tender and of a very agreeable, oyster-like flavor. The top remains in good condition until late the following Spring. Gardeners looking for a variety which grows larger than the Mammoth Sandwich Island will find this the true stock. Pkt. ICc., oz. 20c., $1 / 4$ 1b. 60c., 1b. $\$ 2.00$.

\section{Mammoth Sandwich Island (Improved) SALSIFY}

Market gardeners will find this one of the largest, smoothest, and most profitable in cultivation. The top remains in good condition until late the following Spring. Plt. 5c., oz. 15c., $1 / 4$ 1b. 35c., 1b. $\$ 1.00$

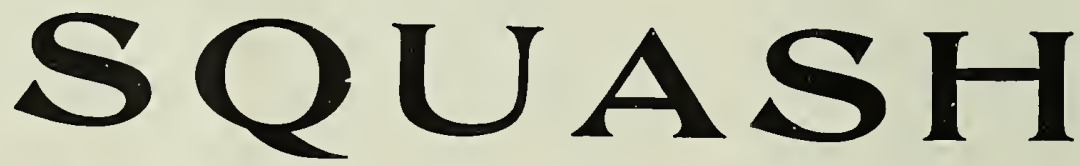

Long Island White Bush. A decided improvement on the old Pkt. Oz. I/4 1b. Lb.

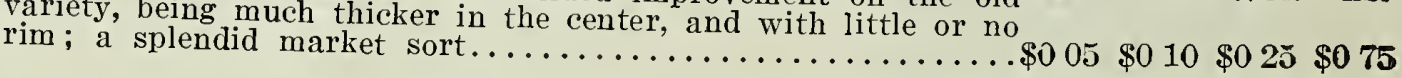

\section{SUMMER VARIETIES}

Yellow Bush Summer Crookneck. Early and prolific; quality
and flavor good.

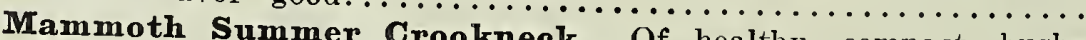
growth,

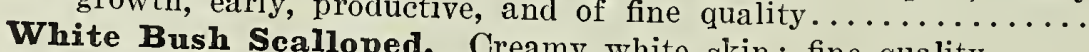
Fordhook. Creamy white skin; fine quality.....

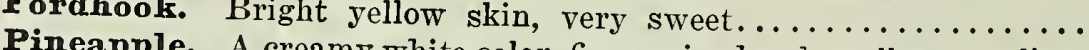
V A creamy white color, fine grained and excellent quality. getable Marrow. Favorite English variety, bearing long, yel-

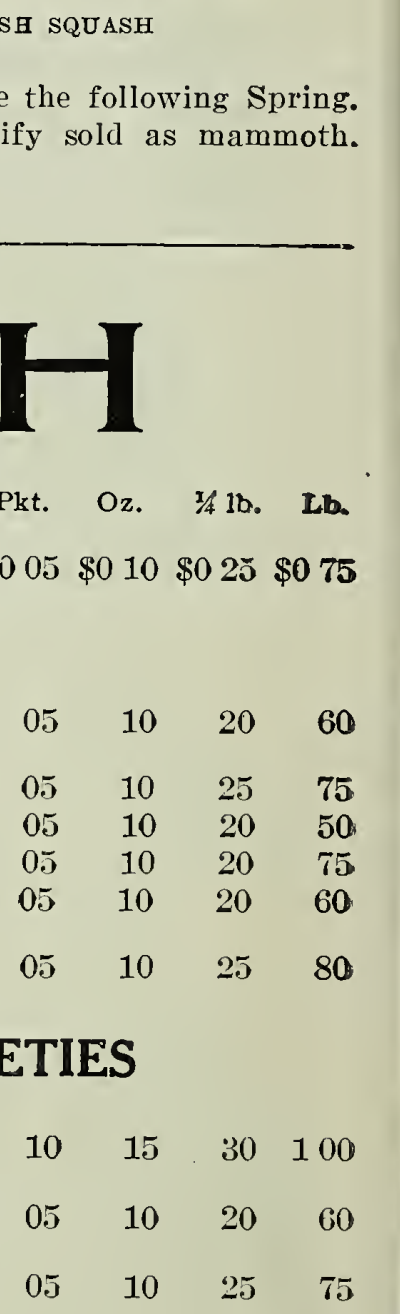

\section{AUTUMN and WINTER VARIETIES}

Delicious (Gregory). The result of years of selection,

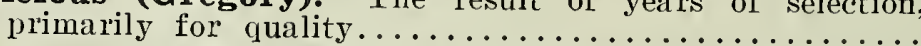

Early Prolific Marrow. An improvement over "Boston Marrow"; more productive; a good keeper............

Delicata. Small, but prolific, and of rich flavor, dry and

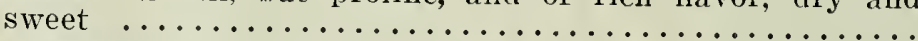

Essex Hybrid. One of the best for Fall and Winter use,

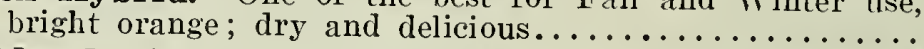

Hubbard. An old favorite, still retaining its place as one of

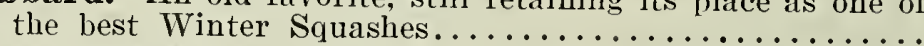

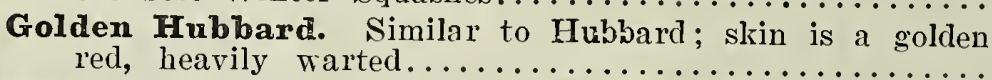

Mammoth Chili. The largest of all Squashes; flesh rich

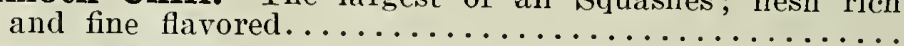

Warted Hubbard. Improvement on Hubbard; skin heav-

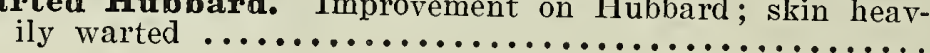

10

05

05

05

05

05

05 $\begin{array}{llll}05 & 10 & 20 & 60\end{array}$
$10 \quad 15$

30

100

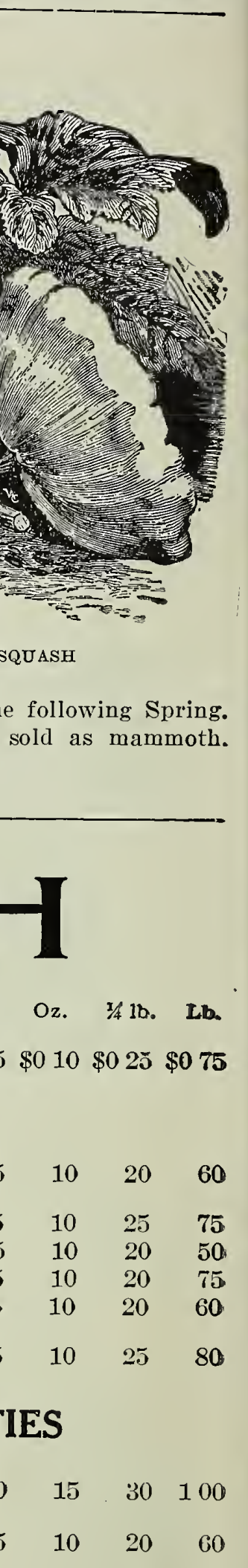

$\begin{array}{lll}10 & 25 & 75\end{array}$

$\begin{array}{llll}5 & 10 & 20 & 60\end{array}$

$\begin{array}{llll}05 & 10 & 20 & 75\end{array}$

$\begin{array}{llll}05 & 10 & 25 & 80\end{array}$

$05 \quad 10 \quad 25$ 


\section{SPINACH SPINACH}

\section{Giant Thick-Leaved SPINACH}

One of the best market sorts. Produces large, thick, strong, green leares, somewhat crumpled. and possesses the raluable quality of standing a long time before running to seed. Pkt.

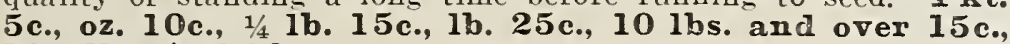
100 lbs. $\$ 14.00$.

\section{Belgium Everǵreen Long-Standing SPINACH}

Without a Doubt the Finest LongStanding Spinach

It has large, dark green, thick leares, and grows close to the ground. Will stand a great amount of hot weather before showing any tendency to run to seed and is an excellent rariety for Wintering orer, as it is rery hardr, and holds its dark green color where other rarieties turn sellow. $\Pi$ e do not recommend it as an early Spinach. The demand by the market gardeners who know this rariety has been so great for the past two seasons that we hare been unable to supply the demand. Te are growing a large quantity this season and hope to be able to fill all orders. Pkt. 5c., oz. 10c., 1/4 1b. 15c., 1b. 40c.

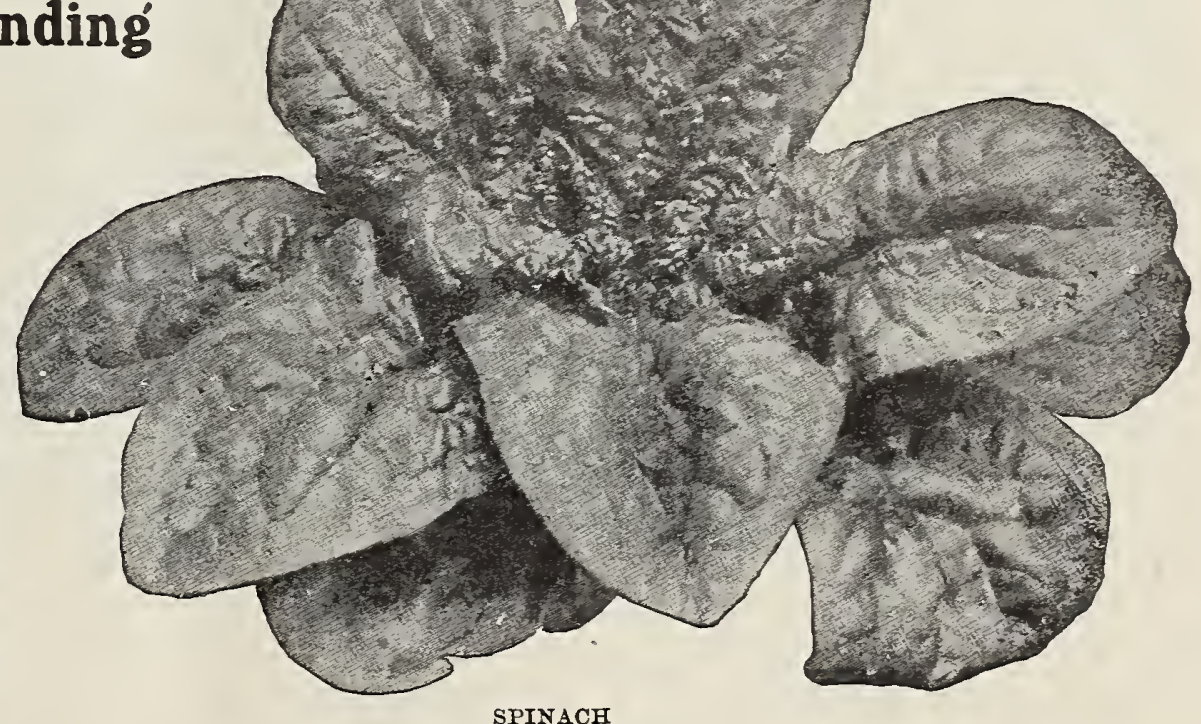

Round-Leaved. A mell-known sort, $\pi$ ith thick, round . Norfolk, Savoy-Leaved. Large, dark green leares, closely sumpled $\ldots \ldots \ldots \ldots \ldots \ldots \ldots \ldots \ldots \ldots \ldots \ldots$
Long-Standing. An excellent compact variety; grows slow $\ldots \ldots \ldots \ldots \ldots$

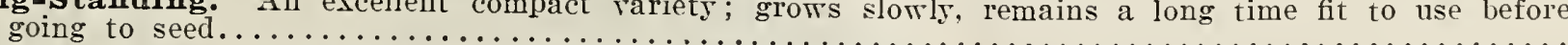

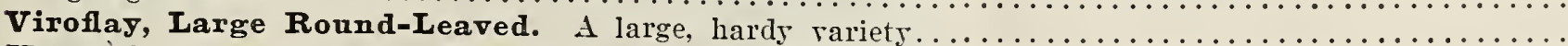
Hardy Winter. A new and superior Spinach, either sown in Spring for early Summer use or Fall

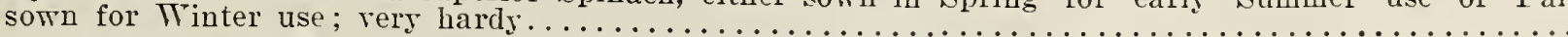

Mammoth Italian. An enormous yielder, and exceptionally good rariety for standing the hot $w$ eather. Victoria. Ters hears, broad, deep green leares; fine quality ; especially raluable for Summer use.... New Zealand. Produces leares in abundance; may be raised in heat and transplanted into good soil..

$\begin{array}{llll}05 & 10 & 15 & 25 \\ 0.5 & 10 & 15 & \mathbf{2 5} \\ 05 & 10 & 15 & 25 \\ 05 & 10 & 15 & 25 \\ 05 & 10 & 15 & 40 \\ 05 & 10 & 15 & 25 \\ 05 & 10 & 20 & \mathbf{7 5}\end{array}$
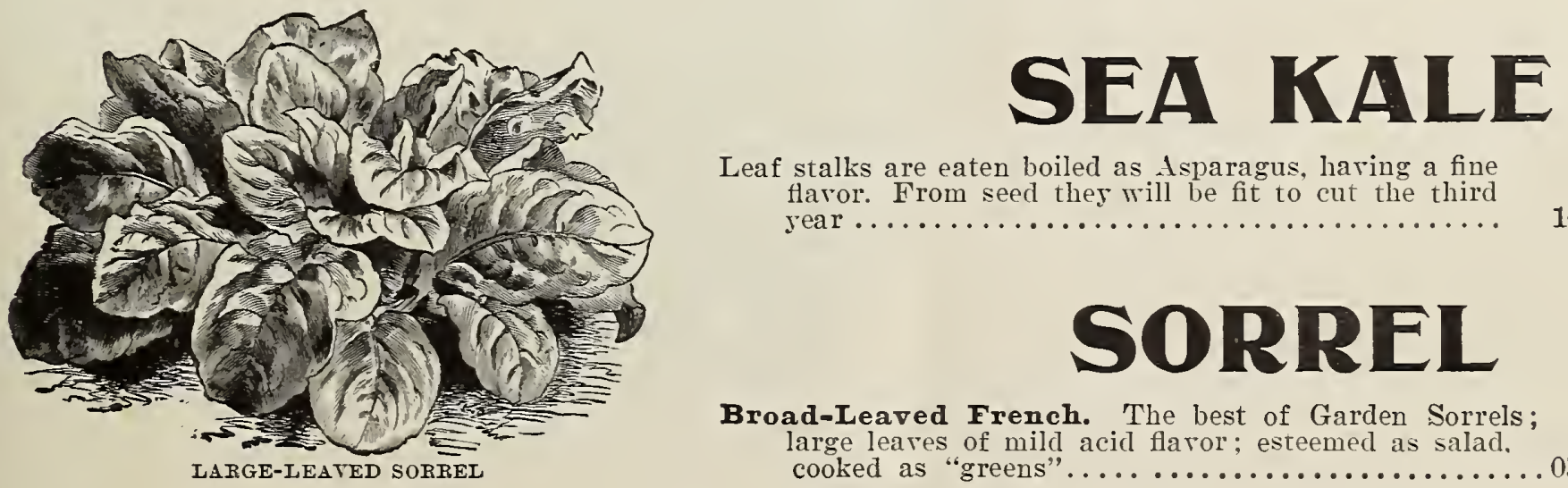

Leaf stalks are eaten boiled as Asparagus, haring a fine flaror. From seed they will be fit to cut the third

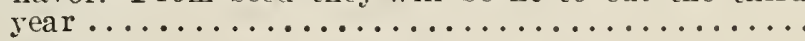

\section{SORREL}

Broad-Leaved French. The best of Garden Sorrels; large leares of mild acid flaror; esteemed as salad. cooked as "greens"........................ 05 


\section{RED TOMATOES}

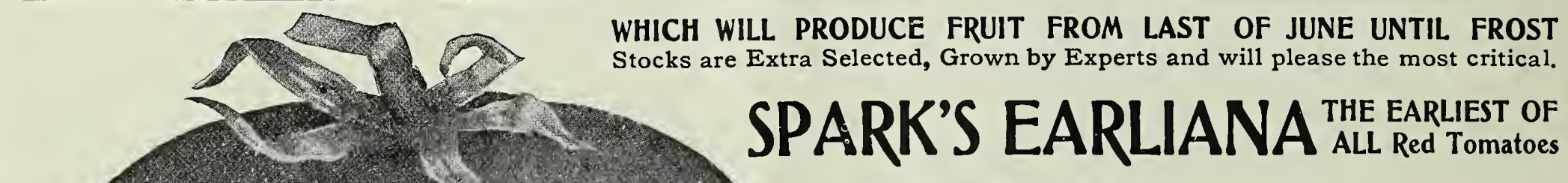

WHICH WILL PRODUCE FRUIT FROM LAST OF JUNE UNTIL FROST

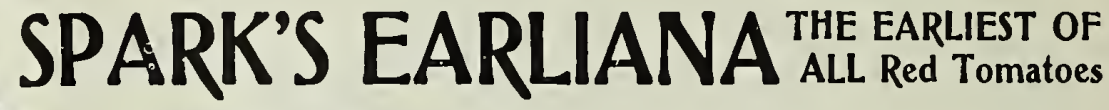

Sparks' Earliana is a wonderfully early and exceedingly prolific medium-sized, uniform, smooth and attractively shaped, bright scarlet tomato of great solidity and fine flavor: It is the earliest tomato grown, having been evolved through keencompetition in a tomato-growing section in Southern New Jersey, where "first in market"appearance and quality being inviting-secures the more profitable returns. The plant is of neat, moderate growth, but quite hardy, and well set with clusters of from 5 to 8 fruits, averaging $2 \frac{1}{2}$ inches through, nearly all ripening up remarkably early and evenly; of great value to the market gardener where early tomatoes are an object. (See cut.) Pkt. IOc., oz. 40c., 1/4, Ib. \$1.00, Ib., \$4.00.

\section{KING OF THE EARLY TOMATO}

\section{An Extra Medium-sized Smooth Red Tomato}

TRIUMPH TOMATO

This new variety ripens with the early Ruby, but is larger, smoother and a heavier cropper. It is nearly as early as the Earliana, and not quite as large. The fruit is borne in clusters, and the vine having very little foliage allows the tomatoes to ripen early and to be planted close together. It is an excellent extra early sort and we highly recommend it. To get best results it should be planted in rich soil. Pkt. IOc., oz. 40 c., $1 / 4$ Ib. $\$ 1.50$, lb. $\$ 5.00$.

\section{CHALK'S EARLY TOMATO}

The best large, early red, smooth variety offered. This magnificent tomato was originated by Mr. James Chalk, a market gardener near Philadelphia. It is very early, good size, smooth and very prolific, and holds up in size until the end. It is very solid, of a beautiful red color, making it a good shipper. Mr. Chalk brings his tomatoes to market while others are bringing Atlantic Prize and Early Richmond, and he gets double the price for them. If you want the best early red tomato you will get it by planting this variety. Pkt. ICc., oz. 40c., $1 / 4$ Ib. \$1.50, lb. \$5.00.

\section{SELECTED STONE TOMATT}

Our stock is distinctly superior to most of that offered under this name, being more uniform, better colored and larger. Vines vigorous and productive. Fruit round, apple-shaped, very large, very deep red in color and astonishingly heavy. Pkt. 5c., oz. 25c., $1 / 4$ lb. Z5c., lb. 2.50.

\section{THE TRIUMPH TOMATO}

This is undoubtedly the Best Late Variety ever offered. It is larger than Stone and does not possess that acid flavor.

It is very solid, almost free from seed, has a bright red color, perfectly smooth, and ripens up to the stem end. It is very prolific for such a large tomato and is especially valuable for canning. Can highly recommend it as the best all-round red tomato. Pkt. IOc., oz. 40c., $1 / 4$ Ib., \$1.25, Ib. \$4.00.

For complete list of Tomatoes

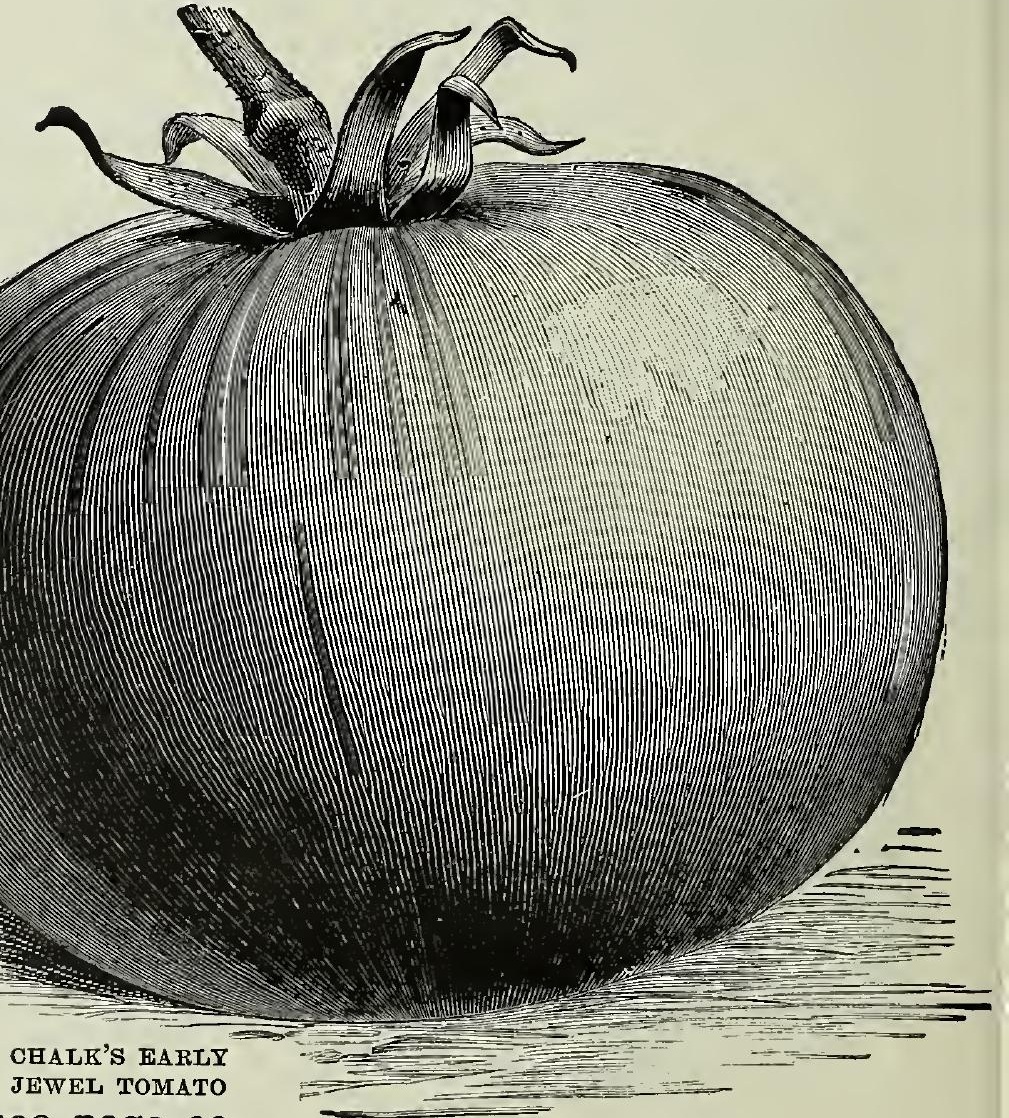




\section{A Page of Pink Tomatoes}

\section{ALL GROWN FROM EXTRA SELECTED STOCKS.}

\section{Early June Pink Tomato}

\section{A Pink Earliana}

Seed grown for us by the originators. Will take the position of the pink varieties which Earliana now holds in the red sorts.

In habit of growth it is similar to the Earliana. The plant is compact, branches freely, with fruit hanging down in clusters of six to ten fruits both in the crown and at the forks of the branches. Shows no tendency to blight. Fruits are smooth of a pleasing pink, and in markets where a pink tomato is desired it will bring 25 per cent. more than any red variety We predict that it will become a more popular variety than the Red Earliana. Pkt. 10c., oz. 40c., 1/4 lb. $\$ 1.50, \mathbf{l b}$. $\$ 5.00$.

\section{Suttorn's Gold Mine Tomato}

A new second early variety of great merit. Sure to please all who plant it. A healthy, vigorous grower. Excedingly prolific. Color rich pink

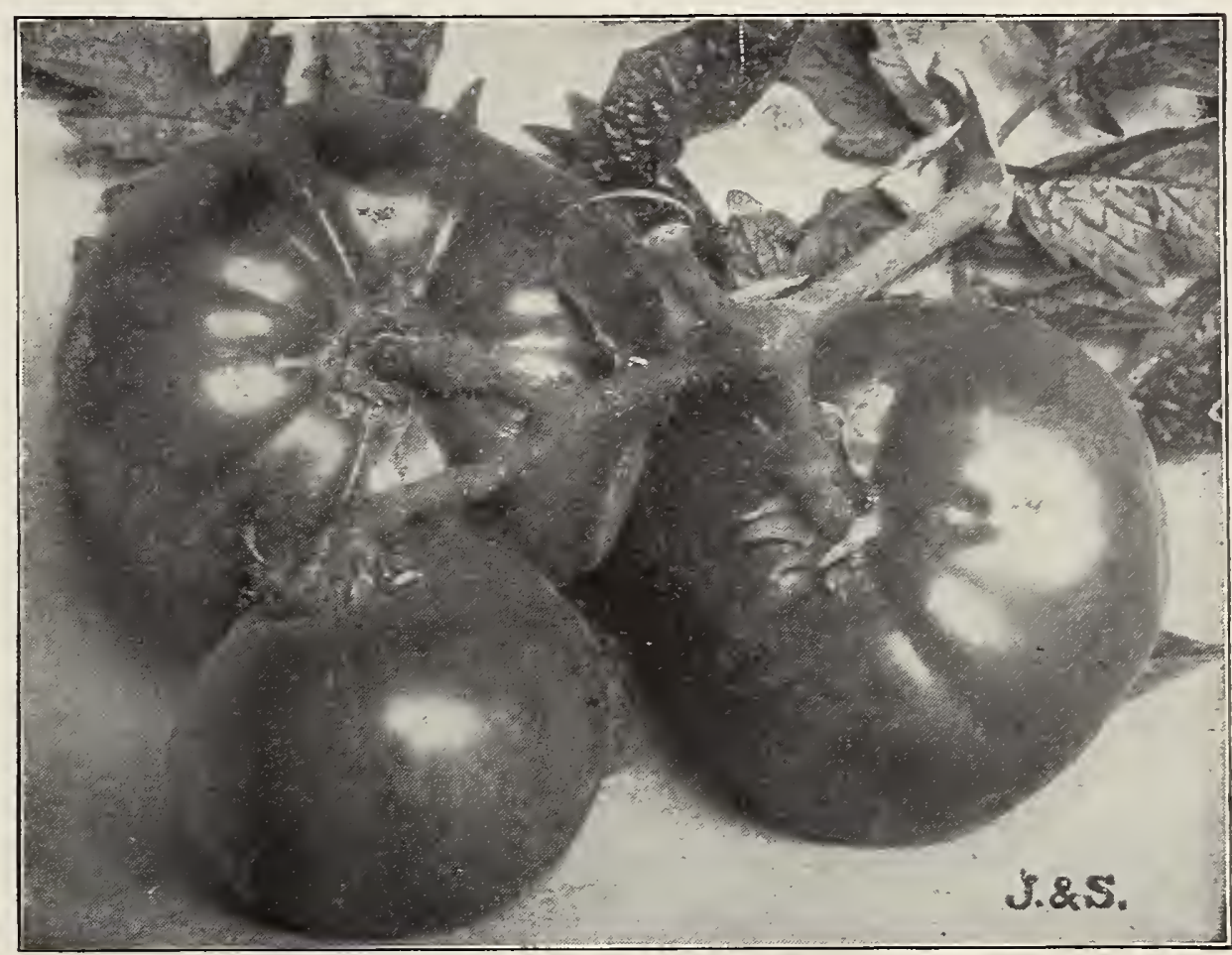

Fruit extra large in size, remarkably solid, smooth, and the size of the fruit is maintained to the end of the season. It is a superbly good shipper and fine keeper, being very solid and firm. It is among the earliest of the large, smooth sorts. A highly valuable variety for Southern growers, owing to the fact that it carries weil long distances, coupled with the fact that we nerer knew it to show any evidence of blight, no matter where grown.

Pkt. 10c., oz. 40c., 1/1/4 Ib. $\$ 1.00$, ib. $\$ 4.00$.

\section{New Magnus Tomato}

This is truly a wonderful Tomato in many respects. It is about the size of Beauty, and maines with it or a little earlier. The color is a deep pink. It is an enormous yielder, is perfectly solid and as smooth as an apple, ripening evenly up to the stem end. An cxcellent variety for medium, early or main crop, and all who planted it last year are highly pleased with it and pronounced it a wonderful Tomato.

Pkt. 10c., 0Z. 40c., 1/4 Ib. $\$ 1.50, \mathrm{lb}$. $\$ 5.00$.

\section{Livingston's Globe Tomato}

This is an early variety, being one of the first to ripen its fruits either in the greenhouse or outside. It is very smooth,

ripens its fruits evenly and the color is a glossy pink. The fruits are borne in clusters which insures a heary crop. The quality is all that can be desired.

Pkt. 10c., oz. 30c., 1/4 lb. 90c., lb. \$3.00.

\section{"Duke of York" Tomato}

\section{OF SPECIAL VALUE TO FLORIDA GROWERS}

One of the grandest Tomatoes recently introduced, color rich glossy pink, similar to our Sutton's Gold Mine, splendid cropper, round in shape, flesh very firm, large size, fine flaror. A leading feature of this superb variety is that it ripens its fruit more uniformly together than any known kind, whilst its profusion of clusters, a veraging eight and ten large evenly formed clusters each, makes it conspicuously handsome. Ripens evenly to the stem, is a strong, healthy grower, not subject to rust or blight, is an enormous cropper, and produces until the vines are killed by frost, holding its size exceedingly well until the last picking. Quality the very best, rery solid and meaty. It is in erery way a desirable variety for market gardeners, as its beautiful appearance always insures an extra price. An exccllent sort for late Summer and Fall. Plants should be "set out" earlier than other late sorts.

Pkt. 10c., oz. 40c., 1/4 lb. $\$ 1.00$, Ib. $\$ 4.00$. 

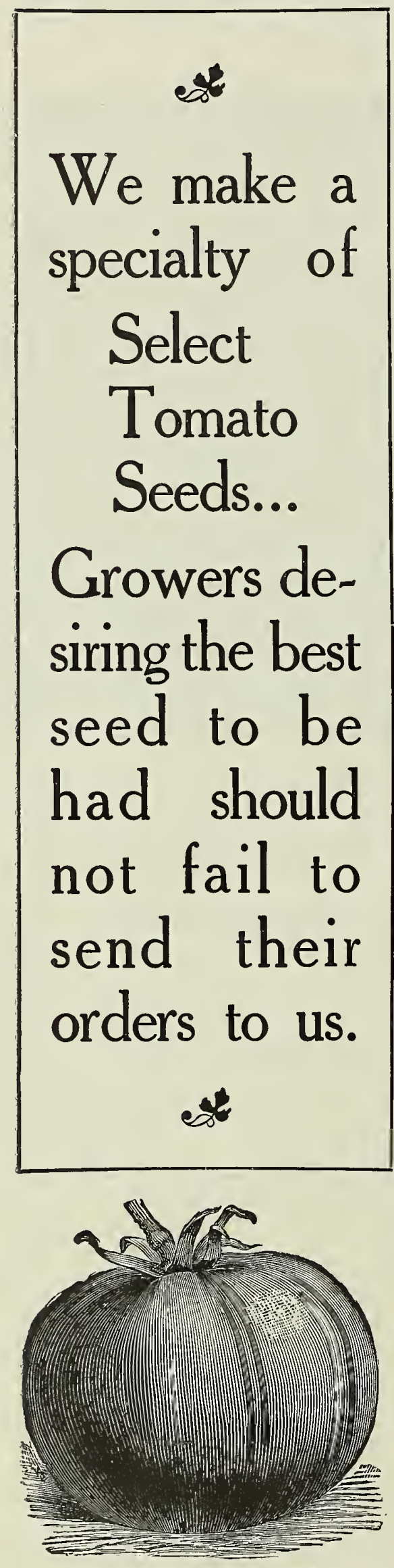

KTNG OF THE FARLY TOMATO
Acme. Well-known, early variety, smooth, prolific; color, purplish pink ............................ $\$ 005 \$ 020 \$ 060 \$ 200$

Beanty. Prolific, smooth; color purplish red; the best of "pur-

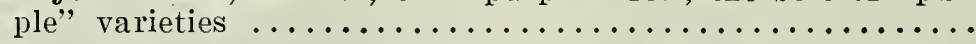

Burpee's Earliest Pink. An enormous yielder, bright pink in color, exceptionally solid, having broad, meaty heart. A

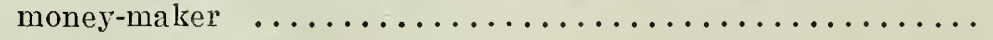

Chalk's Early Jewel. (See page 30.) The best large early red smooth Tomato ever introduced. Our annual sales of this variety are equal to all the other red varieties com-

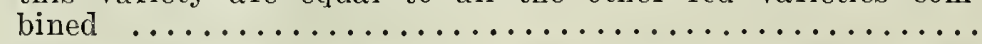

Crimson Cushion. Of immense size; smooth, almost seedless and solid; continuous bearer until frost; color rich crimson

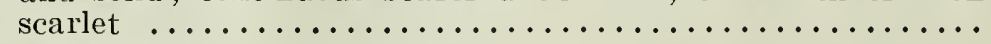

Duke of York. (See page 31.) One of the best pink Tomatoes for general crop. This stands blight better than any other, Tomato. Just the kind for the Southern

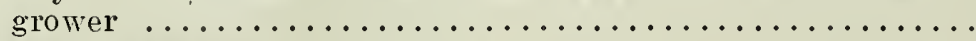

Dwarf Champion. Of dwarf, upright growth, early and prolific; smooth, medium-sized fruits of pinkish purple

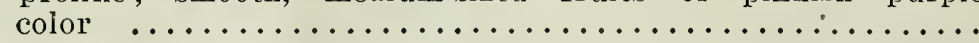

Earliana. (See page 30.) The largest extremely early scarlet Tomato; size medium to large; of uniform shape, a thick, flat-round; solid, of handsome appearance; quality excellent; very prolific for such an early variety; of great value, both to the private and market gardener where early Tomatoes

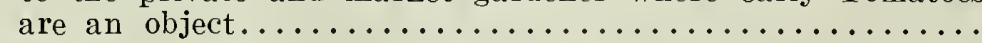

Favorite. A large uniform-shaped Tomato; solid, bright

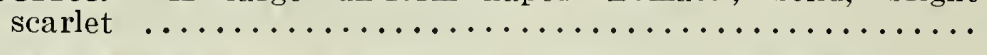

Golden Sunrise. Large, smooth fruits, of a golden color; quality excellent; attractive for slicing and mixing with

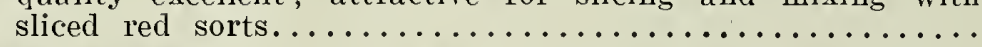

JUNE PINK. (See page 31.) The earliest pink Tomato

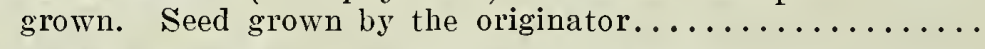

King of the Early. (See page 30.) A few days later than the Earliana, but larger and of a better color. Has always given

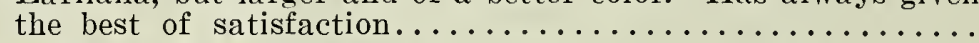

Livingston's Dwarf Stone. One of the best dwarf varieties ever introduced. Can be planted close. Fruits of a beauti-

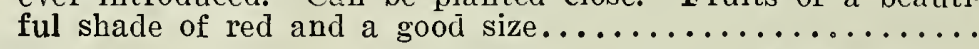

Peach. Very distinct, resembling a peach in size, shape and

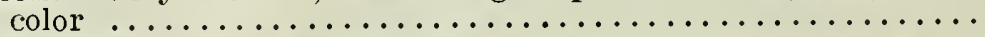

Perfection. Smooth, tough skin of brilliant scarlet; solid and

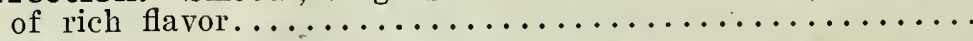

Ponderosa. The largest-fruited Tomato grown...........

Stone. Very handsome, large, almost round, scarlet fruits, very solid and of fine quality; one of the best for cooking and

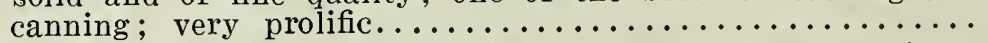

Sutton's Gold Mine. (See page 31.) A second early variety;

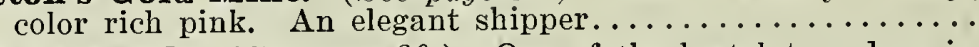

The Triumph. (See page 30.) One of the best late red varie-

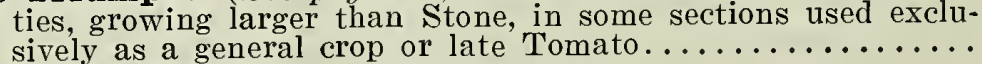

Trucker's Favorite. Purplish red; solid.............. 10

\section{SMALL FRUITING VARIETIES}

Esteemed for preserves, marmalade, etc.

Red Cherry. Bears clusters of bright red fruits, the size of a

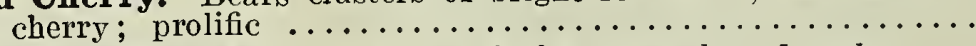

Red Pear-shaped. Bright red fruits ; pear-shaped neck......

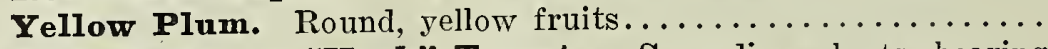
Strawberry, or "Husk" Tomato. Spreading plants, bearing yellow fruits, surrounded by a husk; for preserving.......

05

10

$40 \quad 100 \quad 509$

10

$40 \quad 150 \quad 500$

10

$40 \quad 125 \quad 450$

10

$40 \quad 100 \quad 400$

10

30

$85 \quad 275$
10

05

10

10

10

10

10

05

10

05

10

10

10

$40 \quad 125 \quad 400$

$25 \quad 60 \quad 200$

$25 \quad 75 \quad 250$

$40 \quad 150 \quad 500$

$40 \quad 150 \quad 500$

$25 \quad 90 \quad 300$

$25 \quad 75 \quad 250$

$25 \quad 60 \quad 200$

$40 \quad 125 \quad 400$

$\begin{array}{lll}25 & 75 \quad 250\end{array}$

$40 \quad 100 \quad 400$

$\begin{array}{lll}40 & 125 \quad 400\end{array}$

$25 \quad 75 \quad 250$

\section{5}

05

05

05
25

25

25

25
$75 \quad 250$

$\begin{array}{ll}75 & 250\end{array}$

$75 \quad 250$

$75 \quad 250$ 


\section{6
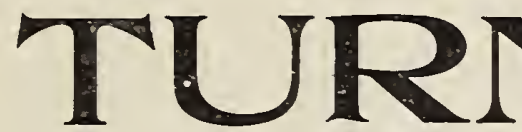 \\ VII
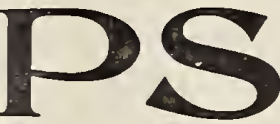 \\ One ounce for 100 feet of drill}

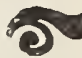

\section{AMERICAN PURPLE TOP \\ อง WHITE GLOBE

The Most Popular Variety of Turnips for the Market Either for Early or Winter Sales

The flesh and bottom are pure white, with a purple cromn. This strain is grown for us by a Long Island market gardener from selected roots. It is the purest and most uniform of all Purple Top Globe Turnips and is a rapid grower; an excellent keeper. Pkt. 5c., oz. 10c., 1/4 1b. 25c., 1b. 75c.

\section{LONG ISLAND IMPROVED

\section{Our Choicest Stock Grows Entirely Without Neck and Very Small Top and Tap Root}

Vers quick growth, good globular shape, excellent table quality and best market rariety. It is thoroughly fixed in type and entirely distinct from ordinary rarieties which are used mainls for feeding stock. It has short leares, grows clean and smooth as a Turnip. Te pronounce this the best and most desirable Ruta Baga grown. and most earnestly commend this fine sort to all who grow for market. Pkt. 5c., oz. 10c., 1/4 1b. 25c., 1b. 75 c.
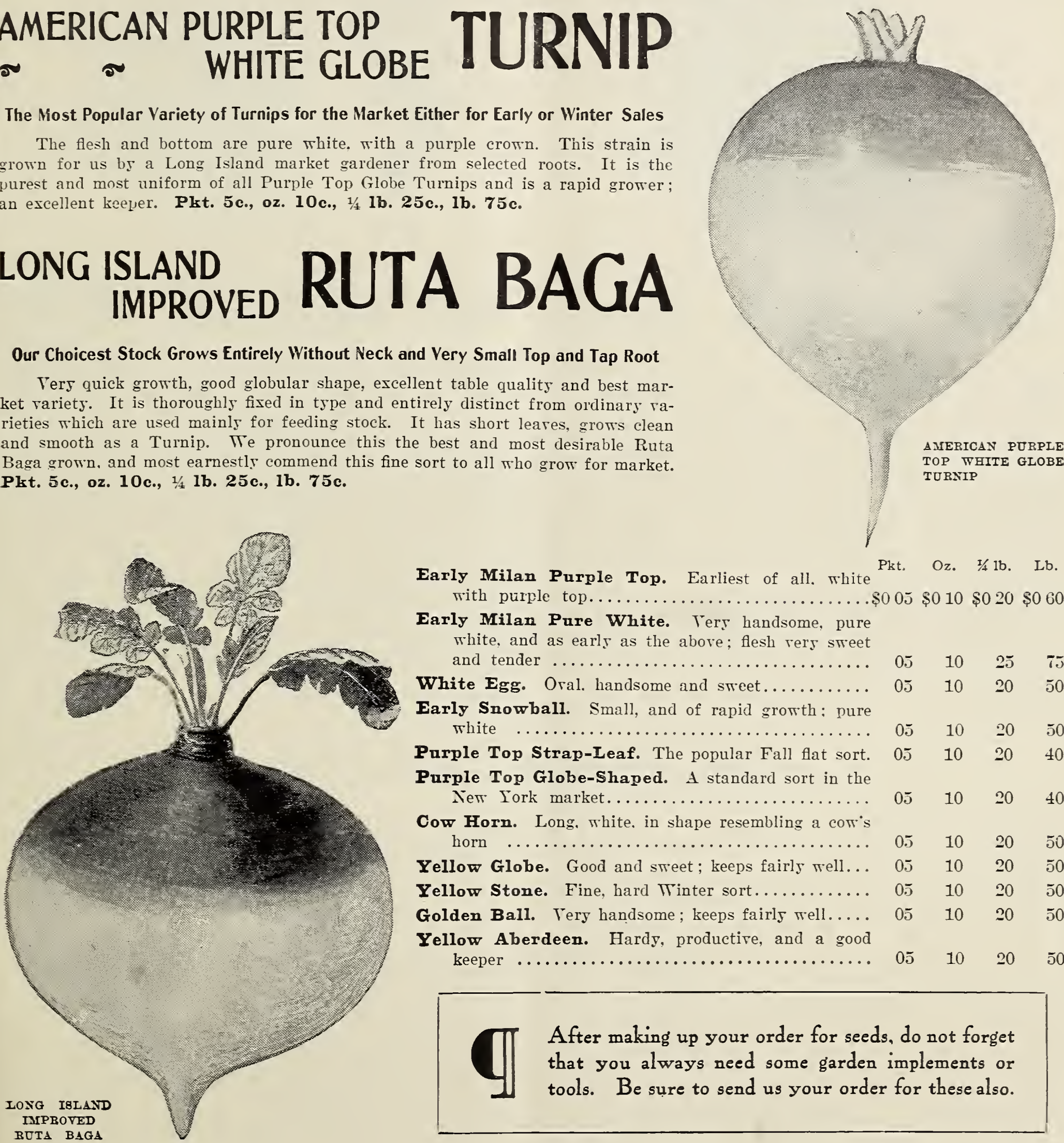

Early Milan Purple Top. Earliest of all. white Pkt. Oz. I/4 Ib. Lb. mith purple top..................... \$0 $05 \$ 010 \$ 020 \$ 060$

Early Milan Pure White. Very handsome, pure white, and as early as the above; flesh $\operatorname{rer} y$ sweet

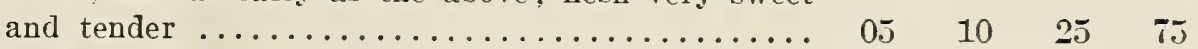

White Egg. Oral. handsome and sweet......... $05 \quad \begin{array}{llll}10 & 20 & 50\end{array}$

Early Snowball. Small, and of rapid growth: pure

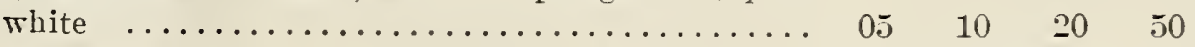

Purple Top Strap-Leaf. The popular Fall flat sort. $\begin{array}{llllll}05 & 10 & 20 & 40\end{array}$

Purple Top Globe-Shaped. A standard sort in the New Tork market.................... $05 \quad 10 \quad 20 \quad 40$

Cow Horn. Long, white, in shape resembling a cow's

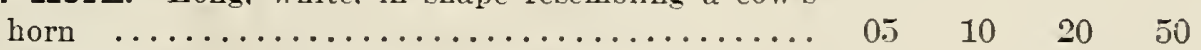

Yellow Globe. Good and sweet; keeps fairly well... $050 \begin{array}{llll}10 & 20 & 50\end{array}$

Yellow Stone. Fine, hard Winter sort.......... $05 \quad \begin{array}{llll}10 & 20 & 50\end{array}$

Golden Ball. Tery handsome ; keeps fairls well.... $05 \quad \begin{array}{llll}10 & 20 & 50\end{array}$

Yellow Aberdeen. Hardy, productire, and a good

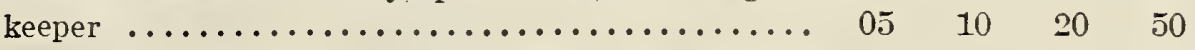

TI After making up your order for seeds, do not forget that you always need some garden implements or tools. Be sure to send us your order for these also. 
J. F. NOII \& CO.,

115 Mulberry St., Newark, N. J.

34

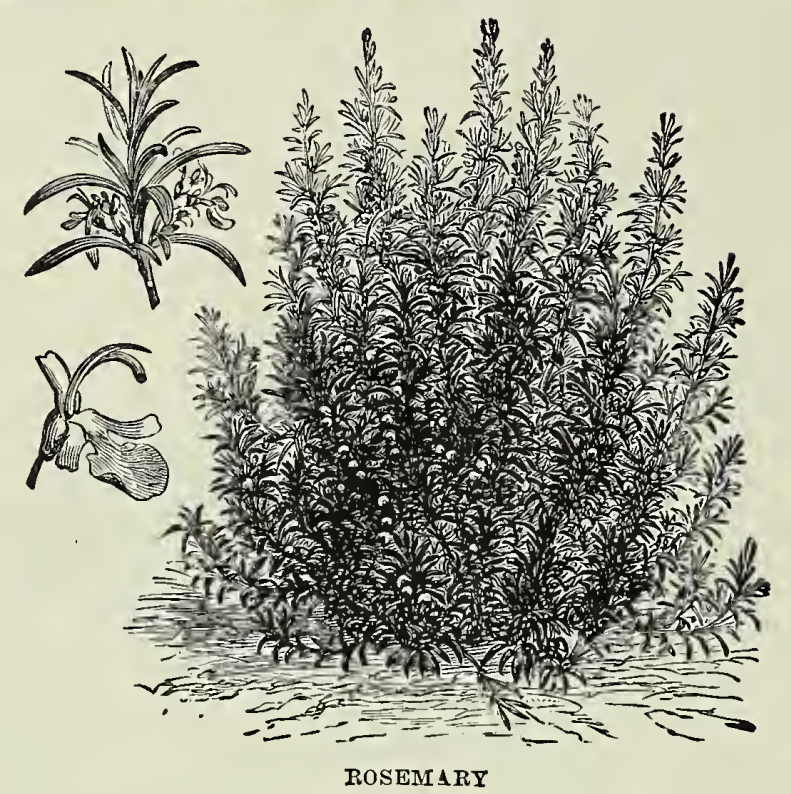

\section{Seeds of Pot,}

Sweet

Anise. Seeds aromatic and carminative.... $\$ 005$ Pkt. $\$ 010 \quad \begin{aligned} & \text { Oz. } \\ & \text { Lb. }\end{aligned}$

Balm. For culinary purposes.......... $05 \quad 30$

Basil. Dwarf or bush. Culinary herb..... $05 \quad 15 \quad 150$

" Sweet. Culinary herb used for flavor-

ing soups, etc.................... $05 \quad 15125$

Bene. The leaves used for dysentery...... $05 \quad 10 \quad 80$

Borage. Leaves used as a salad......... $05 \quad 10 \quad 100$

Caraway. Used in flavoring liquors and

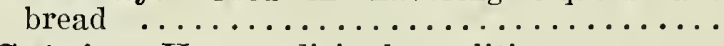

Catnip. Has medicinal qualities.......... 10

Coriander. Seeds aromatic........... 05

Cumin $\ldots \ldots \ldots \ldots \ldots \ldots \ldots \ldots \ldots \ldots . \ldots \ldots$

Dill. Seeds used for flavoring vinegar...... 05

Fennel. Sweet. Seeds a romatic; for flavoring. 05

" Florence. In flavor resembling

celery.$\ldots \ldots \ldots \ldots \ldots \ldots \ldots \ldots \ldots$

Henbane. Has medicinal qualities; poison-
34 High Class Seeds

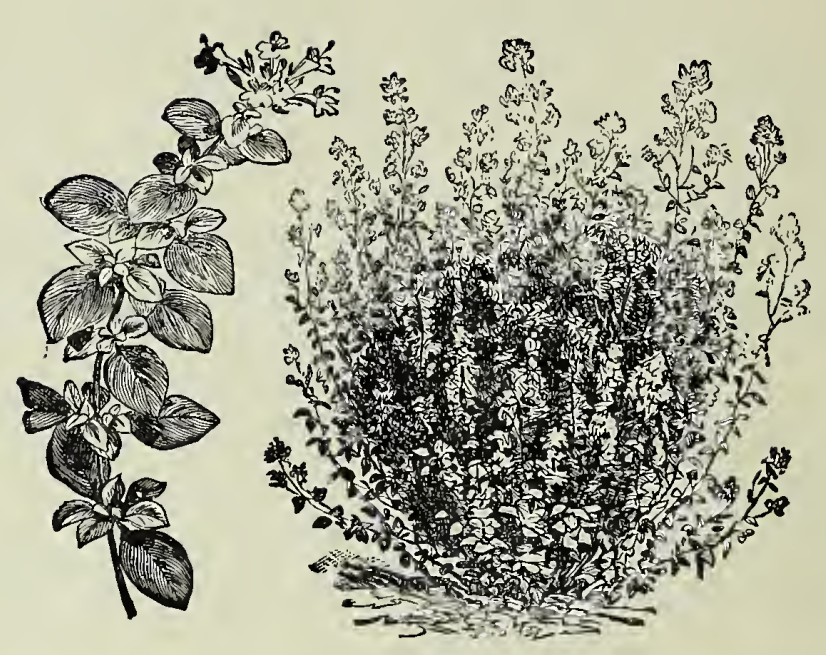

POT MARJORAM

\section{and Medicinal Herbs}

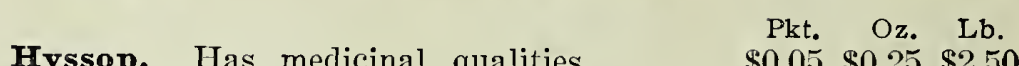

Lavender. For oil and distilled water..... $\$ 00505 \begin{aligned} & \$ 0 \\ & 25\end{aligned} \$ 250$

Marjoram. Pot. Used in seasoning........ $10 \quad 40 \quad 400$

$\begin{array}{llllll}\text {. Sweet. Used in seasoning..... } 05 & 05 & 125\end{array}$

Rosemary. Yields an aromatic oil and
water $\ldots \ldots \ldots \ldots \ldots \ldots \ldots \ldots \ldots \ldots \ldots \ldots$

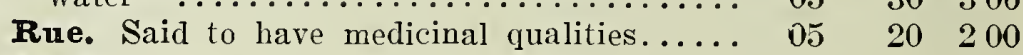

Saffron. Used in medicine, and also in

dyeing $. . \ldots \ldots \ldots \ldots \ldots \ldots \ldots \ldots \ldots . . . \ldots \ldots$

Sage. Common. A culinary he:'?; also used

in medicine $\ldots \ldots \ldots \ldots \ldots \ldots \ldots$

Savory. Summer. Used as a culinary herb.

$\begin{array}{lll}05 & 10 & 75\end{array}$

$\begin{array}{lll}05 & 15 & 150\end{array}$

$\begin{array}{lll}05 & 10 & 75\end{array}$

$\begin{array}{lll}05 & 20 & 200\end{array}$

Tansy. Generally used in bitters..........

Thyme. Broad-leaved English. Used as a

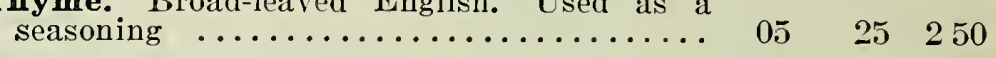

Thyme. French ................. $05 \quad 30 \quad 325$

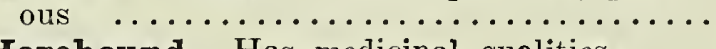

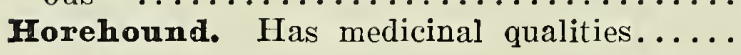

Wormwood. Has medicinal qualities..... $05 \quad 20 \quad 200$

\section{Vegetable Plants and Roots}

\begin{abstract}
Asparagus Roots ..................... $\$ \$ 100$
Cabbage. All varieties................... \$0 $10 \quad 75$

Cauliflower. All varieties................ $20 \quad 125$

Horse-Radish Roots .................... 15 . 75

Lettuce Plants

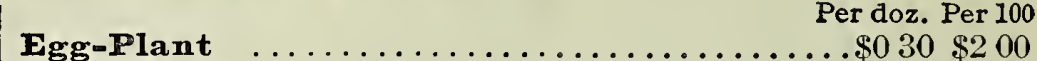

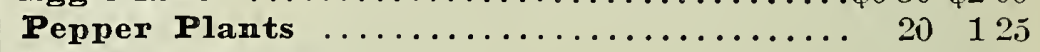

Rhubarb Roots ................. $100 \quad 700$

Tomato Plants. All varieties............ 15 75
\end{abstract}

$\begin{array}{lll}05 & 15 & 100 \\ 05 & 25 & 250\end{array}$

\section{Bird Seeds, Etc.}

Bird Manna. A fine tonic for all caged birds.

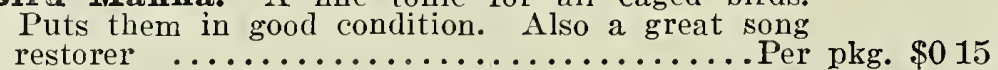

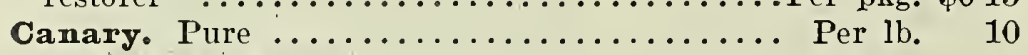

Cuttle Fish Bone.................. Each 03

Hemp Seed $\ldots \ldots \ldots \ldots \ldots \ldots \ldots \ldots \ldots$ Per lb. 10

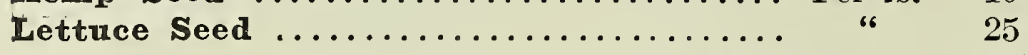

Maw Seer $\ldots \ldots \ldots \ldots \ldots \ldots \ldots \ldots \ldots \ldots \ldots$ Per lb. $\$ 020$

Millet seed $\ldots \ldots \ldots \ldots \ldots \ldots \ldots \ldots \ldots \ldots \ldots$ " 10

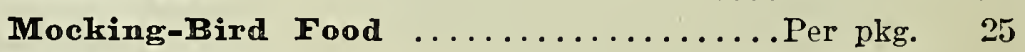

Rape, German ....................... Per lb. 10

Song Restorer, Sheppard's...................... 25

Sunflower Seed for Parrots............ Per lb. 10

Any of the above by mail add 8c. per lb. for postage. Special prices quoted for larger quantities. 


\section{FARM SEEDS}

\section{Prices of Farm Seeds Subject to Change Without Notice. Special Prices can often be made on Large Quantities}

\section{BUCKWHEAT}

Should be sown broadcast about the middle of June. One-half bushel will sow one acre.

New Japanese. It is a splendid yielder, being superior in this respect to the Silver Hull. It is from seven to ten days earlier, and makes better flour than any other kind of Buckwheat. Lb. 20c., bush. $\$ 1.50$.

Silver Hull. This variety is superior in every respect to the common kind. Bush. $\$ 1.50$.

\section{BARLEY}

Two bushels will sow one acre broadcast.

Vermont Champion. Two-rowed, early, hardy and prolific. Pk. 75c., busl. $\$ 2.50$.

Two-Rowed. Pk. 7 כ̌c., bush. $\$ 2.50$.

\section{ENSILAGE CORN}

One and one-quarter to one and one-half bushels will sow one acre.

Sweet Fodder. Pk. 75c., bush. $\$ 2.50$.

Southern Forsetooth. For fodder. Pk. 50c., bush. \$1.75.

\section{OATS}

Two bushels will sow one acre broadcast.

Clydesdale. An early variety of White Oats; heavy cropper, early and productive. Pk. 50c., bush. (32 lbs.) $\$ 1.50$.

Probsteier. One of the most valuable varieties. It is very productive and heavy. Bush. (32 los.) $\$ 1.25$.

\section{PEAS}

One and one-half bushels per acre.

Camada Field. Very valuable for milch cows and ensilage in northern climates. Pk. 75c., bush. \$2.25.

Southern Cow. Largely grown in the southern states and in recent years in the northern states for fodder and plowing under. Price variable; about $\$ 3.00$ bush.

\section{RYE}

One and one-half bushels will sow one acre broadcast.

Mammoth Winter. A variety from Vermont; heavy cropper. Bush. $\$ 2.00$.

winter. Hardy and prolific. Bush. $\$ 1.50$

Spring. Splendid yielder. Bush. $\$ 2.00$.

\section{WHEAT}

One and one-half bushels will sow one acre broadcast.

Fultz (Winter). A standard sort; very reliable, Bush. $\$ 2.00$.

Saskatchewan Fife (Spring). Unequaled for earliness, yield and vigor. Bush. $\$ 2.00$.

\section{MILLET}

One bushel will sow one acre.

Common (Panicum Miliaceum). Bush. $\$ 2.50$.

German or Golden (Panicum Miliaceum Aureum). Medium early; height three to five feet; heads closely condensed: spikes very numerous. Bush. $\$ 2.50$.

Hungarian (Panicum Germanicum). Early; height two to three feet; abundant foliage and slender head; withstands drought, and yields well on light soils. Bush. \$2.50.

Japanese. Very productive. Makes fine fodder and when cured an excellent substitute for hay. Sow about 15 pounds to the acre. Lb. $15 \mathrm{c}$. 100 lbs. $\$ 10.00$.

Pearl or Egyptian. Grows from 8 to 10 feet high. Sow 5 to 8 pounds per acre in drills 2 feet apart. Lb. 15 c., 100 lbs. $\$ 10.00$.

\section{RAPE}

Sow 10 to 12 pounds per acre broadcast and 5 to 6 pounds: per acre in drills 15 inches apart.

Dwarf Essex. For sheep pasture the Dwarf Essex Rape is invaluable. It may be sown in May and will be ready for pasturing in July. Lb. $10 \mathrm{c},, 100$ los. $\$ 7.00$.

\section{SUNFLOWER}

Five pounds will plant one acre.

Mammoth Russians. One of the most profitable crops : the seeds being used for poultry feed, and leaves makes excellent fodder, being relished by all kinds of stock. Lb. 10c., 100 los., $\$ 7.00$.

\section{SORGHUM}

25 pounds per acre in drills.

Early Amber Sugar Cane. Its distinctive features are its earliness and great yield of both sugar and syrup. Culture the same as for corn. Lb. $15 \mathrm{c}, 100$ lbs. $\$ 6.00$.

Early Orange Sugar Cane. A little later than the Amber. It does not succeed well north of latitude 43 degrees. Lb. 15 c., 100 lbs. $\$ 6.00$.

Halapense (Johnson Grass). Sow 35 pounds to the acre. Lb. 20c., 100 lbs. $\$ 14.00$.

\section{VETCHES}

\section{One and one-half bushels per acre.}

Sand, Winter, or Hairy (Vicia Villosa). Produces good crops on poor sandy soils. Being perfectly hardy, it may be sown either in the Spring or Fall, mixed with oats or rye for support; height four or five feet: very nutritious and relished by all kinds of stock. Lb. $15 \mathrm{c} ., 100 \mathrm{lbs}$. $\$ 10.00$.

Spring Tares (Vicia Sativa). Valuable for sowing for green fodder and soiling. Lb. 10c., 100 lbs. $\$ 7.00$.

\section{SUNDRY FARM SEEDS}

BROOM CORN. Evergreen. Free from crooked brush and remains green. Lb. $10 \mathrm{c} ., 100$ lbs. $\$ 7.00$.

POP CORN. The Pop Corns we offer are shelled. 10 lbs. and over will be supplied at the 100-lb. rate. If by mail, add 8c. lb for postage.

White Pearl. Smooth, large white grains. Lb. 10c., 100 lbs. $\$ 7.00$.

Amber Pearl. Very early, 8 to 10 -inch ears; amber-colored kernels, popping white. Lb. 12c., 100 lbs. $\$ 10.00$.

White Rice, or Rat Tooth. Early, white-pointed kernels. Lb. $10 \mathrm{c}, 100$ los. $\$ 7.00$.

KAFFIR CORN. Red. Fine forage for horses and cattle. Sow 5 pounds per acre. Lb. 15 c., 100 lbs. $\$ 6.50$.

IKAFFIR CORN. White. Excellent fodder plant, green or dried and the grain is valuable for feeding poultry. 4 to $5 \mathrm{ft}$. Lb. $10 \mathrm{c} ., 100$ lbs. $\$ 6.00$.

CASTOR OIL PLANT. From which the castor oil of com merce is produced. Oz. 10c., $1 / 4$ lb. $25 \mathrm{c}$., lb. $70 \mathrm{c}$.

FLAX. Qt. 25c., bush. $\$ 4.00$.

WILD RICE. (Zizania Aquatica.) Attracts wild fowl: grows in waters with mud bottom. Lb. 25c., $100 \mathrm{lbs}$ $\$ 18.00$. 


\title{
FARM SEEDS-Continued
}

\section{MANGEL-WURZEL}

\author{
Six pounds will sow one acre.
}

Champion Fellow Globe. The finest globe variety; the bulb is of handsome form, clean single-tap root, and small foliage. $1 / 4 \mathrm{lb}$. 15c., $1 \mathrm{~b}$. 35c.

Golden Tanlkard. Flesh bright gollen-yellow. 1/4 lb. 15c., 1b. 35c.

Mammoth Long Red. One of the largest and most profitable varieties grown for agricultural purposes. $1 / 4 \mathrm{lb}$. 15c., lb. 35c.

Long Red. An excellent variety for feeding stock; a heavy cropper in deep soil. $1 / 4$ lb. 10., lb. $25 \mathrm{c}$.

Yellow Globe. A globular-shaped variety, adapted for growing in shallow soils. $1 / 4$ lb. 10c., lb. $25 \mathrm{c}$.

\section{SUGAR BEET}

White Sugar Beet. A heavy cropper, highly recommended for feeding purposes. $1 / 4$ lb. 15c., lb. 35̌c.

Lane's Imperial Sugar Beet. One of the best varieties for feeding cattle. $1 / 4 \mathrm{lb}$. 15c., 1b. 35 .

\section{CARROT}

Three pounds will sow one acre.

Danver's Half Iong Orange. Very extensively cultivated both for market and agricultural purposes. $1 / 4 \mathrm{lb}$. 25c., lb. $75 \mathrm{c}$.

Improved Long Orange. For field crops this is the best variety grown. $1 / 4 \mathrm{lb}$. $25 \mathrm{c} ., 1 \mathrm{~b} .75 \mathrm{c}$.

Whité Belgian. Very extensively grown for feeding horses and cattle. $1 / 4 \mathrm{lb}$. 25c., $1 \mathrm{~b} .75 r$

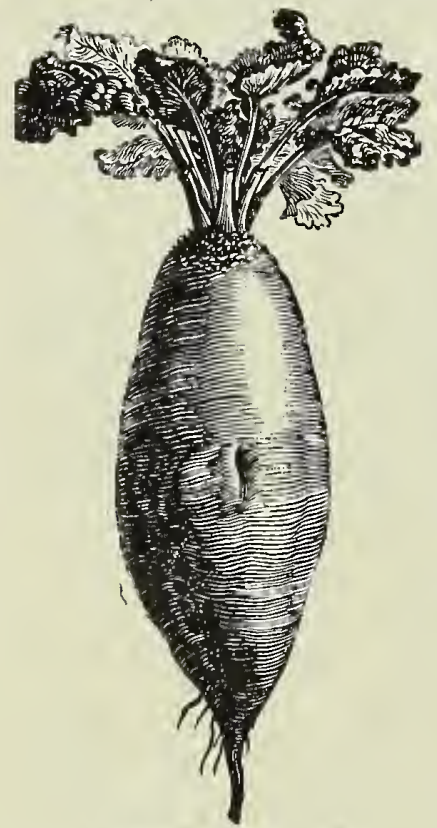

\section{PARSNIP \\ Six pounds will souv onc acre.}

Ideal Hollow Crown. Long, smooth and milky white; the most profitable for feeding stock. Lb. $50 \mathrm{c}$.

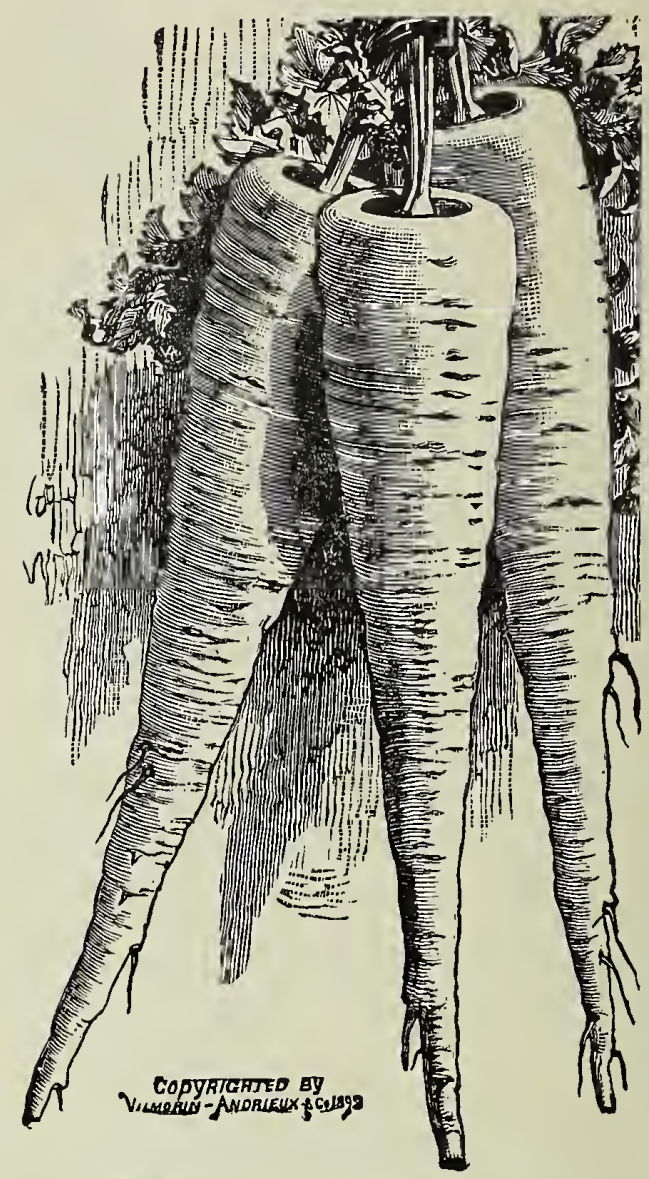

IDEAL HOLLOW OROWN PARSNIP

\section{TURNIP}

Two to three pounds will sow one acre.

Long White or Cowhorn. A quick-growing, long-shaped variety. $1 / 4 \mathrm{lb}$. 20c., lb. $50 \mathrm{c}$

Purple Top, White Globe. A globe-shaped variety valuable for feeding stock. $1 / 4$ lb. 20c., lb. 50c.

Red Top Strap Leaf. A well-known variety, extensively grown for stock. 1/4 1b. 20c., 1b. 50c.

White Strap Leaf. The best white variety. $1 / 4$ lb. 20c., lb. 50c.

Yellow Aberdeen Purple Top. A very hardy and productive variety, good for either table or stock. $1 / 4$ lb. $20 \mathrm{c}$., lb. $60 \mathrm{c}$.

Yellow Globe. The best yellow variety: it keeps well until late in the Spring, and is excellent for stock. $1 / 4 \mathrm{lb} .20 \mathrm{c}$, $\mathrm{lb}$. $50 \mathrm{c}$.

\section{RUTA BAGA, Russian or Swedish Turnip}

Two to three pounds will sow one acre.

Champion Swede. A handsome globe-shaped variety; the best for stock. 1/4 lb. 20c., lb. 50c.

MAMMOTH LONG RED MANGEL-WURZEL

Improved American. A yellow-fleshed, purple top variety grown for stock. 1/4 lb. 20c., lb. 50c.

\section{FIELD CORN}

Eight quarts will plant one acrc in hills; three bushels will sow onc aere broadeast or half that quantity in drills.

\section{DENT VARIETIES}

Eureka. The grandest Yellow Dent in cultivation. Qt. 20c., peck 65c., bush. $\$ 2.00$.

Wood's Northern White Dent. The earliest large White Dent. Qt. 20c., peck 75c., bush. $\$ 2.50$.

Golden Beauty. A large Golden Dent; exceedingly productive. Qt. 15c., peck 60c., bush. $\$ 2.00$.

Fundred-Day Bristol. Very early and productive; light yellow grain. Qt. $15 \mathrm{c}$, peck $50 \mathrm{c}$, , bush. $\$ 1.75$.

Ieaming. Low-set ears of good size; golden grain, productive. Qt. 15c., peck 60c., bush. $\$ 1.75$.
Hickory King. Largest grains and smallest cob of any white corn. Qt. 15c., peck 65c., bush. $\$ 2.00$.

\section{FLINT VARIETIES}

Longfellow. A large 8-rowed Yellow Flint; ripens as far north as Mass. Qt. 15c., peck 60c., bush. \$1.75.

Compton's Early. Eariest Yellow Flint, ripening in from 76 to 85 days. Qt. 15 c., peck 50c., bush. \$1.75.

Large White Flint. Large, handsome, well-filled ears. Qt. $15 \mathrm{c}$, peck 50c., bush. $\$ 1.75$.

Large Yellow Flint. (Early Canada Yellow.) Largely grown in the North. Qt. 15c., peck 50c., bush. $\$ 1.75$. 


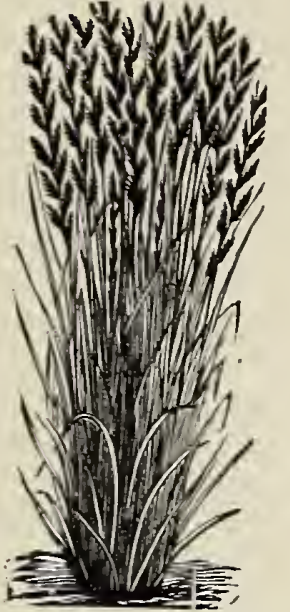

CRESTED DOG'S TAIL

\section{Noll's Select List of Recleaned}

\section{GRASSES \\ A

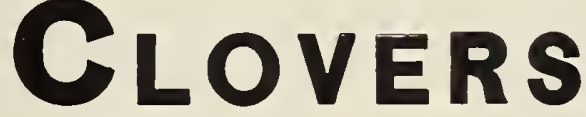

All of our Grass and Clover Seeds are new crop, choicest quality, of highest germination, and free from weed seeds. When

this superior grade is considered, our prices will be found VERY LOW

Prices subject to variation. - - Special quotations for large quantities

\section{GRASSES}

AWNLESS BROME GRASS. (Bromus Inermis.) Will stand long droughts and produce

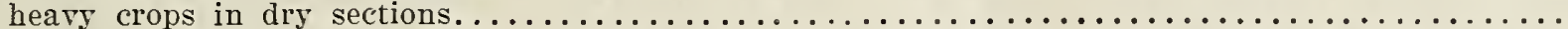

CANADA BLUE GRASS. (Poa Compressa.) Useful for sowing on hard clay and poor soils CREEPING BENT GRASS. (Agrostis Stolonifera.) Excellent for lawns; succeeds well in

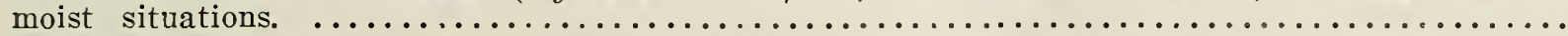

CRESTED DOG'S TAIL. (Cynosurus Cristatus.) An excellent grass for hard, dry soils, ralu-

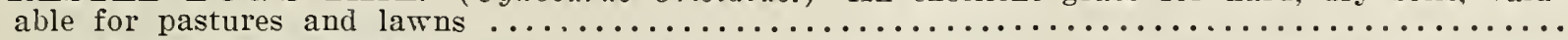

ENGLISH RYE GRASS. (Lolium Perenne.) A very nutritious, rapid-growing variety; valu.

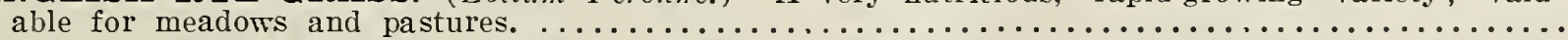

HARD FESCUE. (Festuca Duriuscula.) One of the most desirable dwarf grasses, excellent for

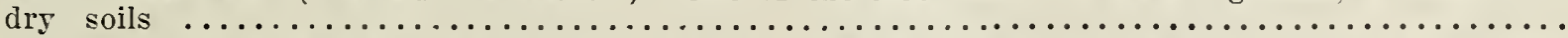

HUNGARIAN GRASS. (Panicum Germanicum.) This is a species of millet. growing less rank with smaller stalks, often yielding two or three tons of hay per acre. One bushel per acre...

ITALIAN RYE GRASS. (Lolium Italicum.) A raluable European variety, adapted to any

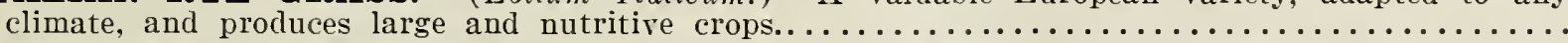

KENTUCKY BLUE GRASS. (Poa Pratensis.) Well known and extensively grown in all

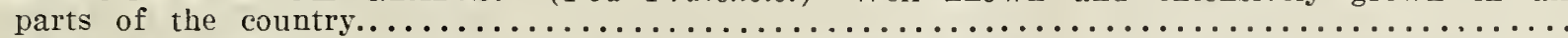

MEADOW FESCUE. (Festuca Pratensis.) A valuable grass for permanent pastures, rery

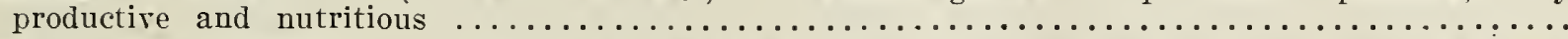

MEADOW FOXTAIL. (Alopecurus Pratensis.) One of the earliest and best pasture grasses,

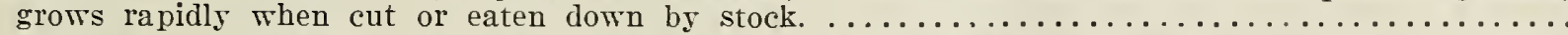

ORCHARD GRASS. (Dactylis Glomerata.) A raluable pasture grass, adapted for growing

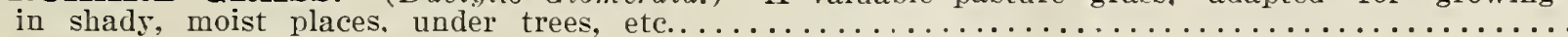

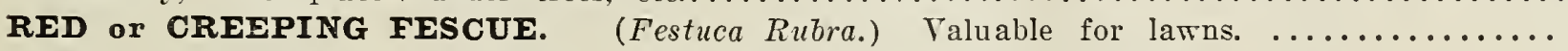

RED TOP GRASS. (Agrostis Tulgaris.) Valuable for either pastures or lamns .........

RHODE ISLAND BENT GRASS. (Agrostis Canina.) Excellent for larns or pastures....

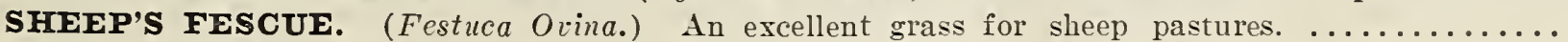
SWEET VERNAL, TRUE PERENNIAL. (Anthoxanthum Odoratum.) It should be sown

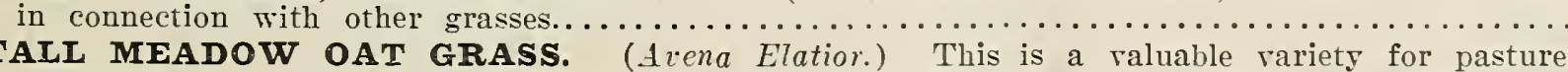
TIMOTHY. (Phleum Pratense.) A rariety producing a profitable hap crop in almost any

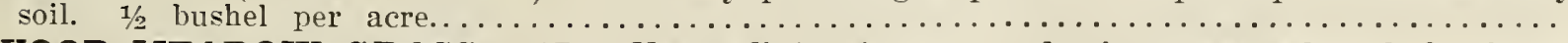
WOOD MEADOW GRASS. (Poa Nemoralis.) A very productive grass, adapted for lav ns

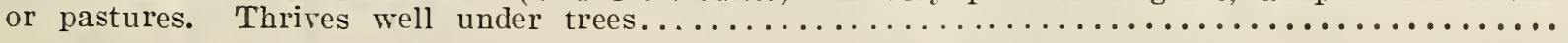

\section{CLOVERS}

ALFALFA, or LUCERNE. (Medicago Sativa.) One of the most raluable forage plants ....

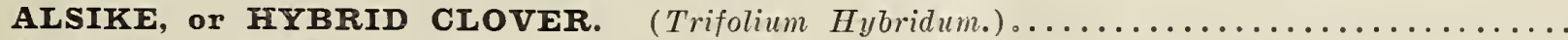
MAMMOTH RED, or PEA-VINE CLOVER. (Trifotium Pratense Perenne.) Grows much

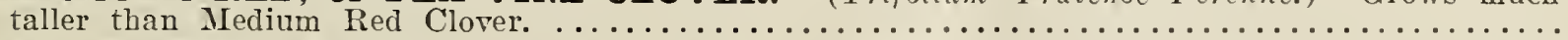

RED CLOVER, Medium. (Trifolium Pratense.) This is the common Red Clorer so largely

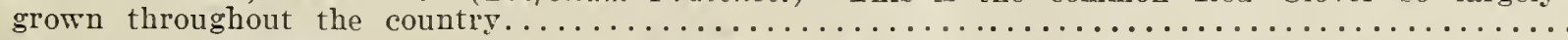

SCARLET CLOVER. (Trifolium Incarnatm.) An annual variety producing large crops of

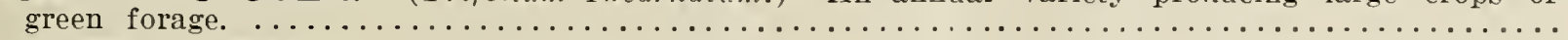

WHITE CLOVER. (Trifolium Repens.) The best variety for lawns; valuable in permanent

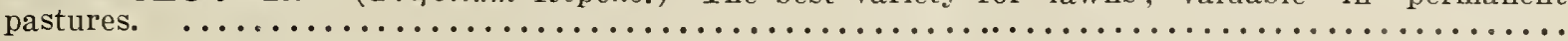

$60 \mathrm{lbs}$.

$60 \mathrm{lbs}$.

$60 \mathrm{lbs}$.

$60 \mathrm{lbs}$

$60 \mathrm{lbs}$.

60 Ibs.

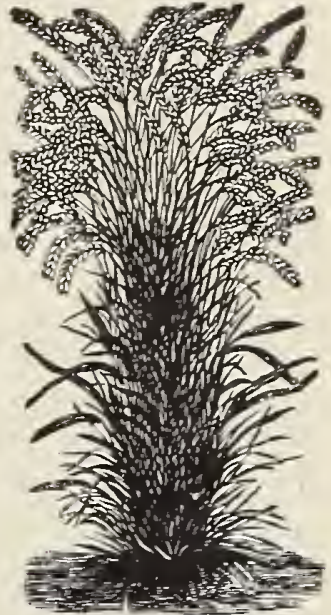

WOOD MEADOW

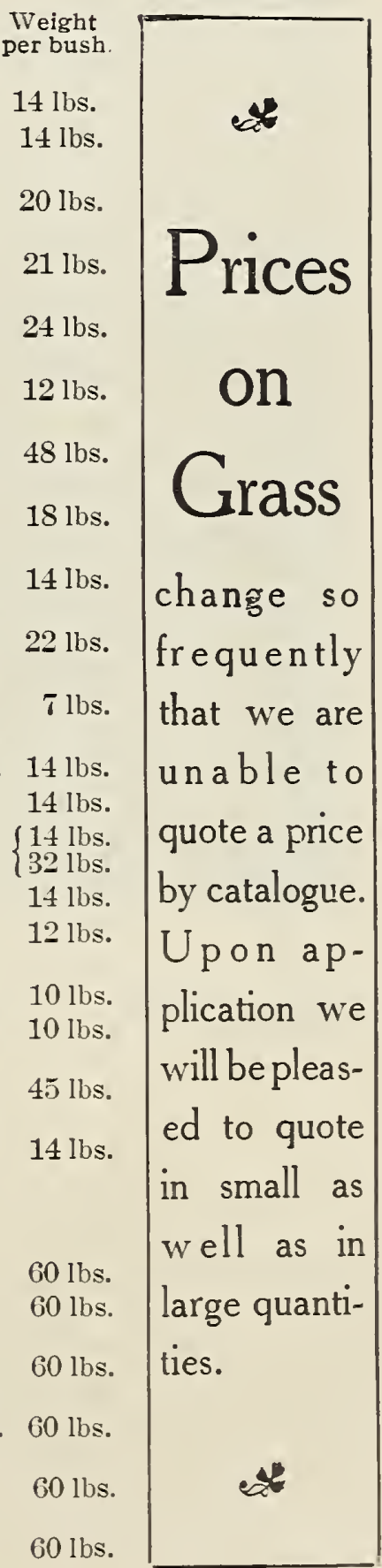




\section{Lawns and Lawn Grass Seed}

The proper time to sow grass seed depends, of course, upon the locality. In the central and eastern states from March 20 to April 20 is the best time. Seed may also be sown in the fall, provided it is done early enough to secure a good, strong growth before winter sets in. The sowing should be done when the ground is moist, and a subsequent rolling is always advisable.

As soon as the frost is out of the ground in the spring, the land should be gone over with a heavy roller. Winter frosts loosen the soil, and rolling is necessary to compress it again. If grass seed is to be sown, this should be done first and the rolling immediately afterward.

All turf-forming grasses are improved, both in vigor of root-growth and in fineness of texture, by frequent mowings. Too close cutting should be guarded against, however, especially during the hot summer months, when the roots require sume topgrowth to protect them from the burning sun. A good top-growth is also necessary to protect the roots from severe winter frosts. Fertilize the Lawn or Grass Plot. Well fertilized ground stands the extreme drought much better than ground which is poor. We recommend Noll's Perfection Lawn Dressing, $\$ 40.00$ per ton, $\$ 4.50$ per 200-1b. sack, $\$ 2.50$ per 100 lbs. or 5 lbs. for 25 c.

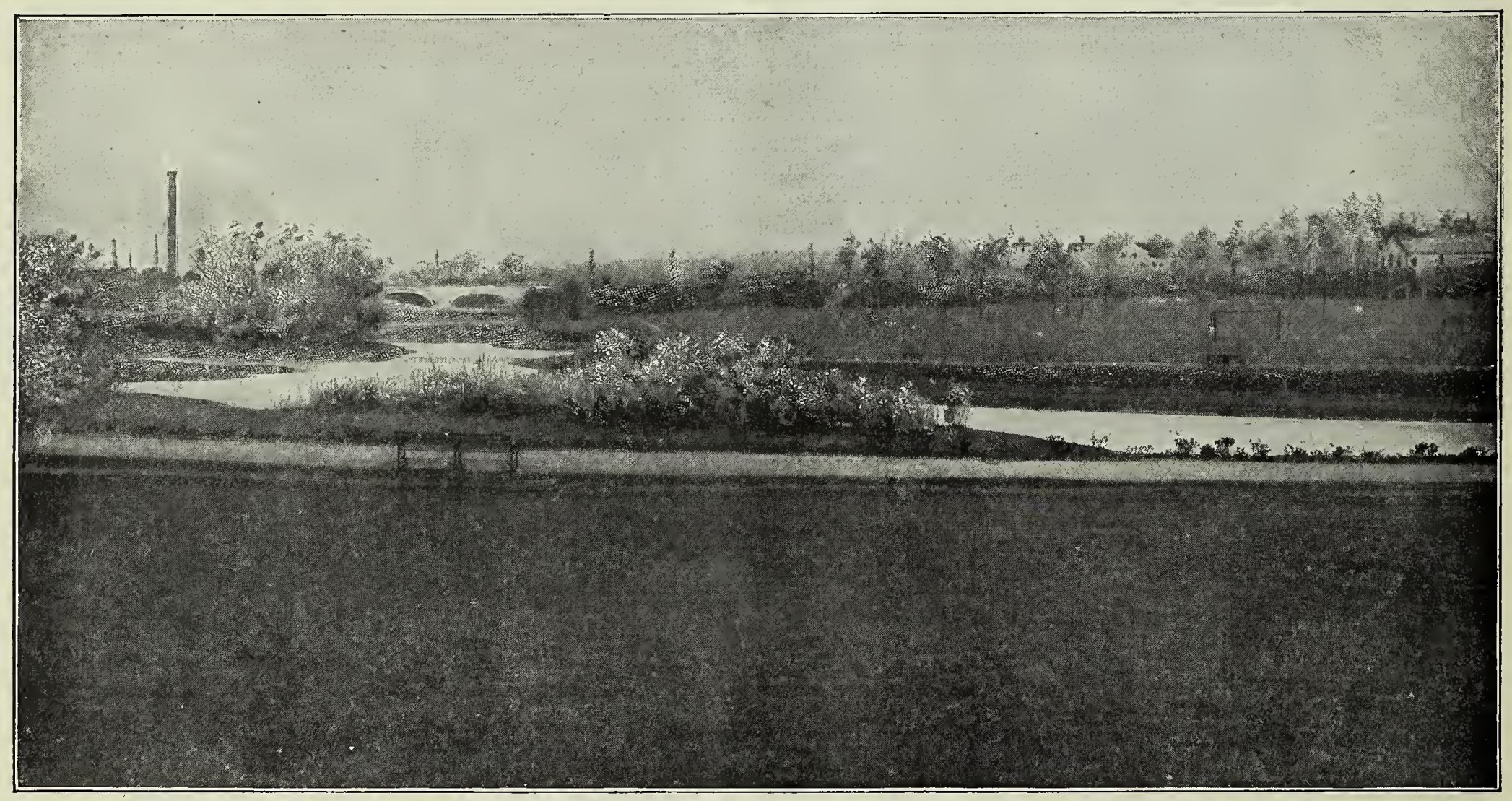

\section{Noll's \\ "Branch Brook \\ Park" \\ Lawn Grass Seed}

Named after our new Branch Brook Park, where forty tons of grass seed have been sowed, and which we supplied in competition with the largest seed houses in this country, This mixture is made of the finest varieties, winch produces an even, dense growth of permanent sward, as early in the season as it is possible to do. This mixture contains no annual grasses for quick show to the detriment of a good lawn, but only those of lasting value and hardiness, which, once established, need little reseeding for years. Some of the best lawns in Newark, the Oranges and vicinity have been produced from this seed, and we have no hesitancy in stating that no better lawn grass mixture can be had. While most lawn grass mixtures will not average orer fourteen pounds to the bushel, this weighs twenty pounds per measured bushel.

The quantity required for making new lawns is five bushels per acre, and for renovating old lawns one to two bushels per acre. One quart is required for 200 square feet of new lawn.

Prices: $25 \mathrm{c}$. per quart, 2 quarts $40 \mathrm{c}$, 4 quarts $75 \mathrm{c}$., peck $\$ 1.25$, bush. $\$ 5.00$. For other grass seed mixtures see inside back cover page. 


\section{GENERAL LIST OF \\ NOLL'S SUPERIOR FLOWER SEEDS}

For the convenience of customers we have numbered all the Flower Seeds, which saves a great deal of time and labor. For instance, if you wish one packet of Alyssum Carpet of Snow, order one packet No. 71, etc Please be careful to give the correct number, as a mistake in the number would result in getting the wrong seeds.

Our list has again been carefully revised and all inferior varieties discarded. A Trial Order will convince any. one of the high quality and superiority of our varieties. Florists, especially, will find our seeds of unequaled quality.

\section{ABUTILON}

(Chinese Bell-Flower, or Flowering Maple)

Greenhouse shrubs of strong growth and easy cultivation, freetowering, with beautiful drooping bell-shaped flowers.

15 Magnificent New French Hrbrids, Mixed. Handsomest varieties only, comprising upwards of 25 sorts ; make splendid blooming house plants for winter; 2 to $6 \mathrm{ft}$. Pkt. 10c., trade pkt. 30c., oz. $\$ 3.00$.

\section{ACHILLEA}

25 The Giant Pearl. Producing an abundance of charming, large, double, pure white flowers throughout the summer; splendid for cutting; excellent florist's flower; hardy perennial, of easy culture; 18 in. Pkt. 10c., trade packet $30 \mathrm{c}$.

\section{ALYSSUM}

These flower profusely throughout the season, thriving in flower garden, wiudow boxes, vases, etc.; also well adapted for ribbon lines and edgings; very fragrant; hardy annual.

70 Sweet Alyssum. White; trailing; the finest variety for cut flowers; 8 in. Pkt. 5c., trade pkt. 10c., oz. 20c.

71 Carpet of Snow. Pure white; grows only two to three inches high and flowers profusely; in fact, it is a perfect carpet of snow throughout the season. We have counted as many as 300 heads of snow-white flowers open on one plant at one time. The best sort for pot culture. Pkt.10c., trade pkt. 20c., oz. 50c.

72 A. Saxatile Compactum (Basket of Gold). Beautiful golden yellow; $1 \mathrm{ft}$. Pkt. 5c., trade pkt. 10c.

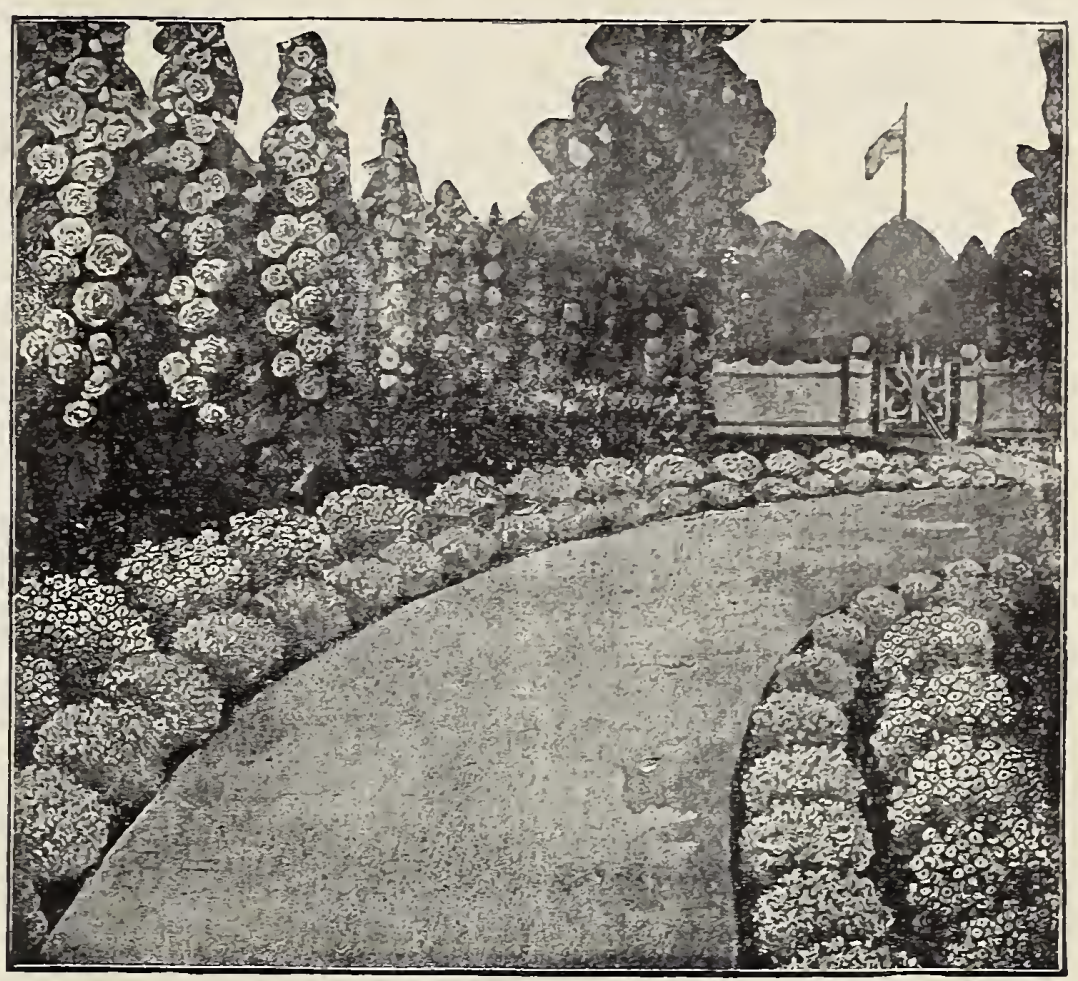

A SLGGESTION FOR A BORDER.

In the outer row, Alyssum Little Gem; second row, Ageratum Blue Perfection and Hollyhocks behind.

\section{AGERATUM}

One of the leading plants for beds or borders and very useful where cut flowers are in demand; in bloom the whole summer; also good for winter blooming; annuals.

63 Blue Gem. Beautiful, large, dark blue flowers; finest blue variety for bedding and pot culture; 6 in. Pkt. כ́c., trade pkt. 15c., oz. 50c.

61 White Gem. The best white rariety for bedding or pot culture; 6 in. Pkt. 5c., trade pkt. 15c., oz. 50c.

65 Mixed. Pkt. 5c., trade plt. 10c., oz. 35c.

\section{AMARANTHUS}

Ornamental foliage and flowering annuals of striking effect; they are of rapid growth, easy cul'cure and very showy, with flower spikes of richly colored foliage. For semi-tropical gardening they are unique and effective; $3 \mathrm{ft}$.

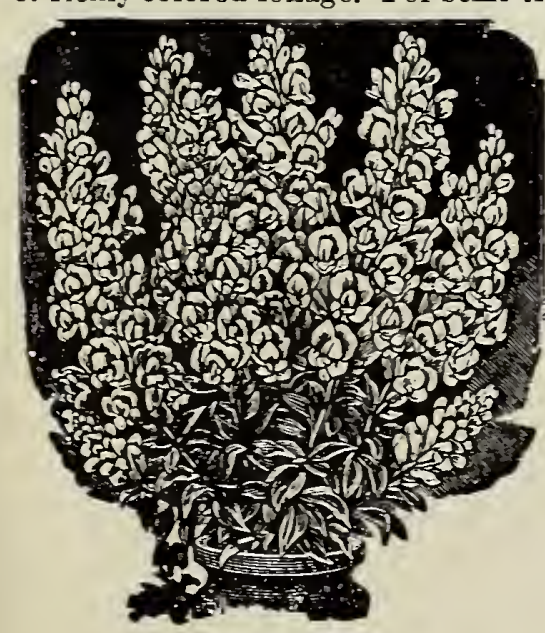

ANTIRRHINCM.
80 A. Caudatus (Lore-Lies-Bleeding). Long racemes of curious looking blood-red, drooping flowers. Pkt. 5c., trade pkt. 10c.

82 A. Tricolor Splendens (Joseph's Coat). Foliage very brilliant and showy; yellow, scarlet and green; a great improvement on A. Tricolor. Pkt. 5c., trade pkt. 10c.

83 Mixed. Comprising over 20 beautiful sorts. Pkt. 5́c., trade pkt. 15c.

\section{ANTIRRHINUM (Snapdragon)}

One of our most showy and useful border plants. They succeed in any good garden soil, and are very effective in beds; will bloom until frost if seed pods are removed. Hardy perennials, blooming the first year.

120 New Giant-Flowering, Mixed. Embracing 12 of the most beautiful varieties, rivaling the finest orchids in color and markings. Extra quality; $2 \mathrm{ft}$. Plt. 10c., trade pkt. 20c., oz. 60c.

121 Tom Thumb, Finest Mixed. Remarkably gorgeous colors, in endless variety, unsurpassed for beds, borders or pots; 10 in. Pkt. 10c , trade pkt. 20c, oz. $75 \mathrm{c}$

122 Queen of the North. The finest of all Snapdragons; forms an excellent plant one foot high, each plant occupies a space of one to one and one-half feet, and is densely covered with large white flowers. A beauty for beds and borders; also valuable for pot culture. Pkt. 10c., trade pkt. 15c., oz. 50c.

123 Tall, Mixed. Pkt. 5c., trade pkt. 15́c., oz. 10c. 


\section{AQUILEGIA (Columbine)}

Very handsome, ornamental hardy perennial plants, growing one to three feet high ; of easy cultivation, and bearing in profusion large flowers of novel shape and in great variety of color.

133 Single, Mixed. Extra quality, embracing 20 beautiful sorts; 2 ft. Pkt. 5c., oz. 30c.

134 Double, Mixed. Comprising 25 of the handsomest and best sorts only; 18 in. Pkt. 5c., trade pkt. 15c., oz. 50c.

\section{ARISTOLOCHIA}

140 A. Elegans (Dutchman's Pipe). A rapid-growing climber; large heartshaped foliage, and very curious brownish-purple flowers, resembling a pipe; hardy perenuial; $30 \mathrm{ft}$. Pkt. 10c., trade pkt. $30 \mathrm{c}$.

\section{ASPARAGUS}

146 A. Plumosus Nanus. This graceful climbing asparagus has foliage finer than that of the most delicate fern, and will last for weeks after being cut. It is an excellent house plant, succeeding under almost any conditions. Pkt. 15c., 100 seeds $\$ 1.00$, per $1000 \$ 8.00$.

147 A. Sprengeri (Emerald Feather). One of the best plants to grow in suspended baskets, for greenhouse or for outdoors in the summer. The fronds frequently grow four feet long and are now considered indispensable in all fine decorations; grows readily from seed. Pkt 10c 100 seeds $30 \mathrm{c}^{2}$

\section{Mammoth-Flowered Chrysanthemum Asters \\ DODBLE AQDILEGIA.}

These magnificent Asters we have secured from a celebrated Japanese aster specialist. They combine more points of merit than any other one class of asters, bearing extraordinarily large semi-spherical double flowers, averaging five inches in diameter, of the most symmetrical form. They are of great durability, the petals being of splendid substance, withstanding storms, rains and hot suns better than any other asters, coming through such vicissitudes as gloriously beautiful as ever. The plants form sturdy, compact bunches, and are remarkably regular in form and even in height, so that a row or bed of them presents an unbroken sheet of brilliant color. The finest tall class for either cut flowers or pot culture; height about 22 inches.

160 White. Handsome, pure satiny white, fine form.

161 Scarlet. Magnificent, glowing crimson-scarlet.

162 Peach Blossom. Extra fine, lovely bright rose.

166 Light Blue. Beautiful light azure blue.

Each color, pkt. 10c., trade pkt. 50c., oz. $\$ 2.50$.

170 Noll's Superb, Mixed. Pkt. 10c., trade pkt. 40c., oz. \$2.50.

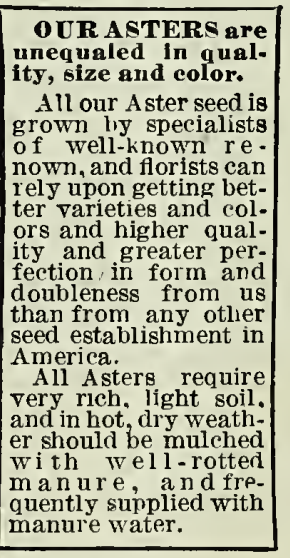

ASPARAGUS SPRENGERI.

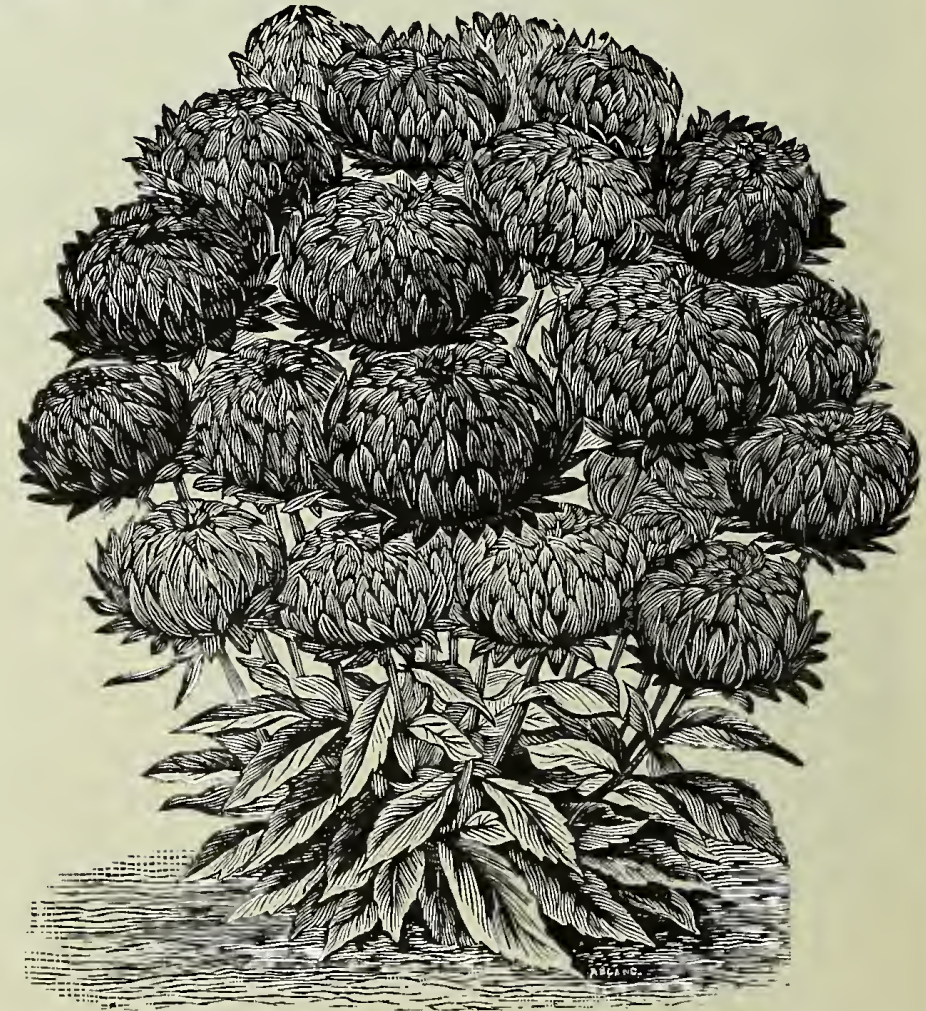

MAMMOTH-FLOWERED CHRYSANTHEMUM ASTERS.
The earliest flowering variety. 175 White. 176 Pink. 177 Light Blue.

Each of the above, pkt. 10c., trade pkt. 20c., oz. 75c.

\section{IMPROVED VICTORIA ASTERS}

Undoubtedly the most handsome aster in cultivation, and we have an excellent strain of it. Flowers large and perfectly double, of globular shape and beautifully imbricated; plants are of fine pyramidal form. 13/4 feet high. 200 Pure White.

201 Apple Blossom.

202 Light Blue. Each of the above, pkt. 10c., trade pkt. 40c., oz. $\$ 2.50$.
203 Crimson.

204 Violet.
178 Dark Blue.

179 Crimson.

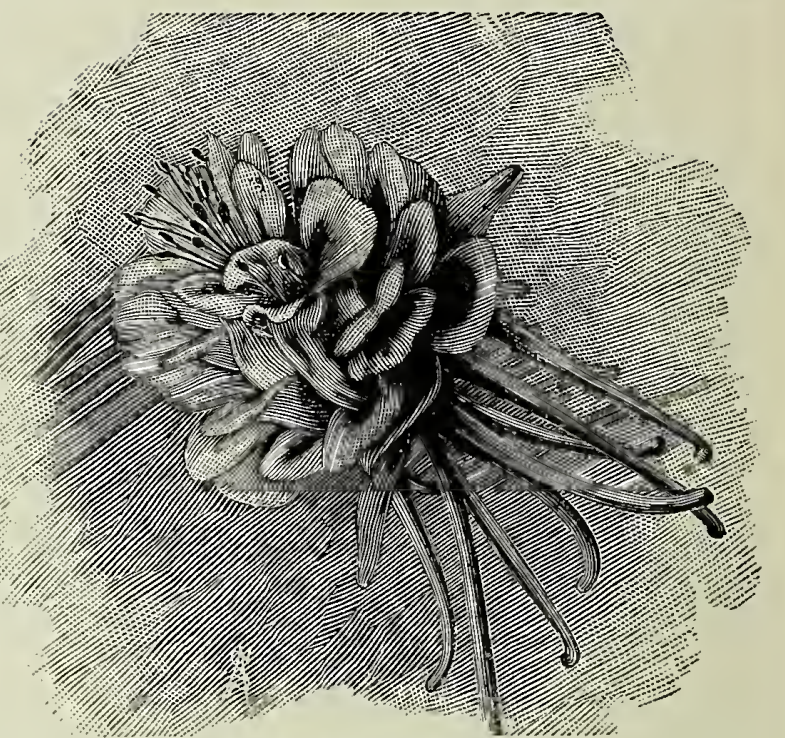




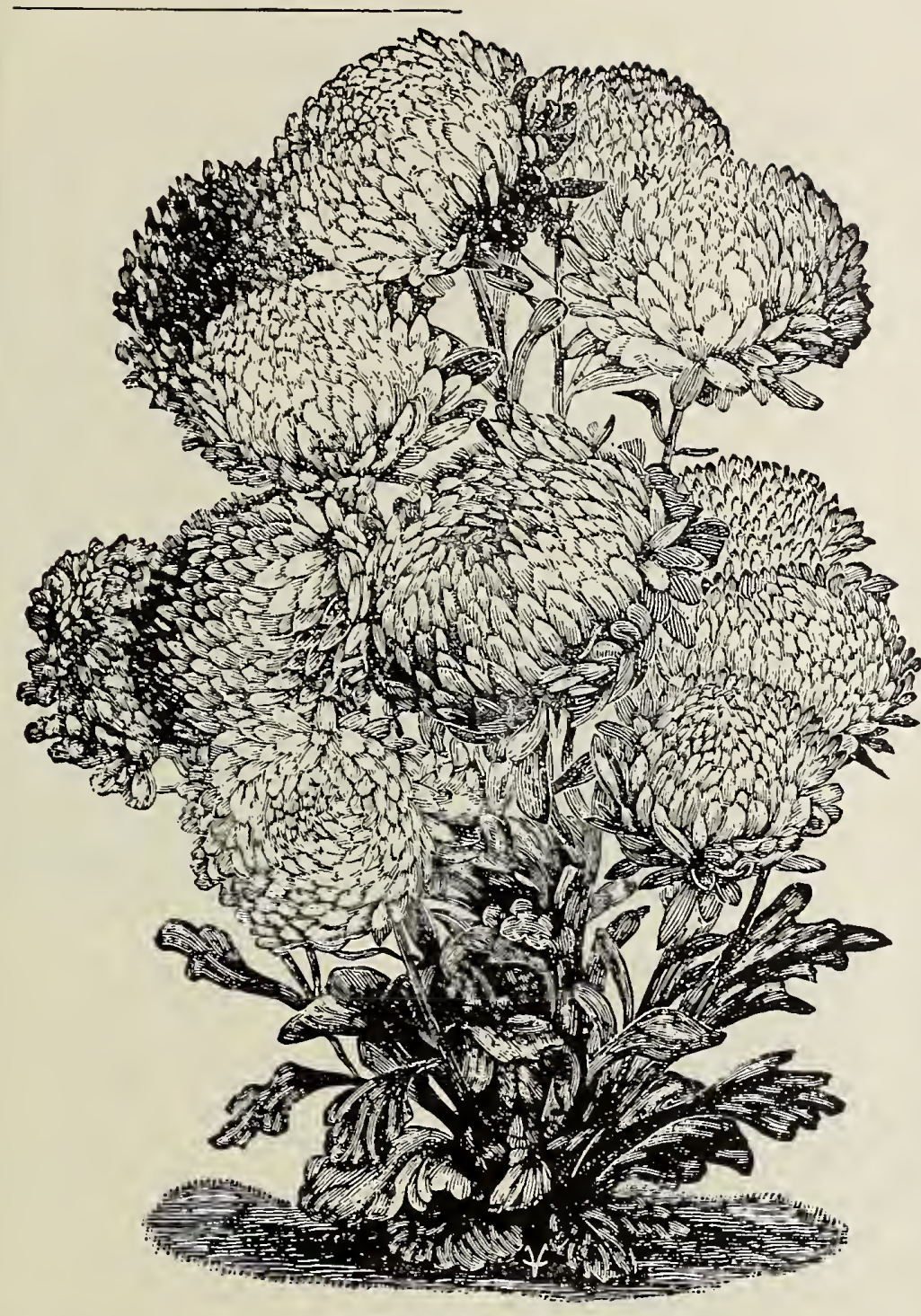

J. F. NOIL \& CO.,

115 Mulberry St., Newark, N. J.

\section{PEONY-FLOWERED ASTERS (Truffaut's)}

One of the handsomest sorts. The plants grow from 18 to 24 inches high ; the flowers are borne on long, wiry stems, are very large, from three to four inches in diameter, very double and in shape like a peony.

210 Pure White.

211 Gravelotte, deep blood red.

214 Purple, Violet. 223 Superb, Mixed. Comprising all the above and many other showy sorts. Pkt. 10c., trade pkt. 30c., oz. $\$ 2.00$.

\section{SEMPLE'S LATE-FLOWERING BRANCHING ASTERS}

Superior to any other class of late-flowering branching aster, lengthening the aster season until frost. The flowers are large, four inches across, are very double, of purest colors, and are borne on long stems, They begin blooming about the 1st of September. Strong growers. 18 inches to 2 feet high. Grand for cutting. 230 White.

231 Lavender.

232 Indigo.

233 Shell Pink.

Each color, pkt.10c., trade pkt. 25c., oz. $\$ 1.50$

234 Mixed. Pkt. 10c., trade pkt. 25c., Oz. $\$ 1.50$.

\section{GIANT COMET ASTERS}

Flowers of immense size, often 6 inches across, composed of long, wavy, twisted petals, gracefully formed into loose yet densely double half-globes. The plants attain a height of 15 inches, each plant bear. ing from 20 to 30 of these magnificent flowers on long stems, which gives them an added value for cutting for vases.

253 White.

254 Bright Rose.

255 Dark Violet.

256 Azure Blue.

257 Crimson.

258 Mixed.

Each, pkt. 10c., trade pkt. 30c., oz. $\$ 2.00$.

\section{OSTRICH FEATHER ASTERS}

This magnificent class bears some resemblance to the Comet, differing in the candelabrum form of growth and greater freedom of bloom, but its greatest merit is in the flowers, which are of immense size; made up of much longer, more loosely formed petals, equaling the best Japanese chrysanthemums. We offer two distinct and beautiful colors, viz.

259 Pure White. Pkt. 10c., trade pkt. 30c., oz. $\$ 2.00$

260 Pink. Pkt. 10c., trade pkt. 30c., oz. $\$ 2.00$.

261 Tall Asters. Many kinds and colors, mixed. Pkt. 5c., oz. \$1.50.

262 Dwarf Asters. Many kinds and colors, mixed. Pkt. 5c., oz. $\$ 1.50$

263 Large-Flowering Perennial Varieties, mixed. Pkt.10c., trade pkt. 40c.

DOUBLE BALSAMS (Lady Slipper, or Touch-Me-Not)

Remarkable perfection now attained in this old favorite summer-garden annual; height, one and a half to two feet.

323 Extra Double, Mixed. Embracing a large variety of handsome, large double flowers. Pkt. 5c., trade pkt. 15c., cz. 50c.

324 Perfection Camellia-flowered, Superb Mixed. This strain is the highest

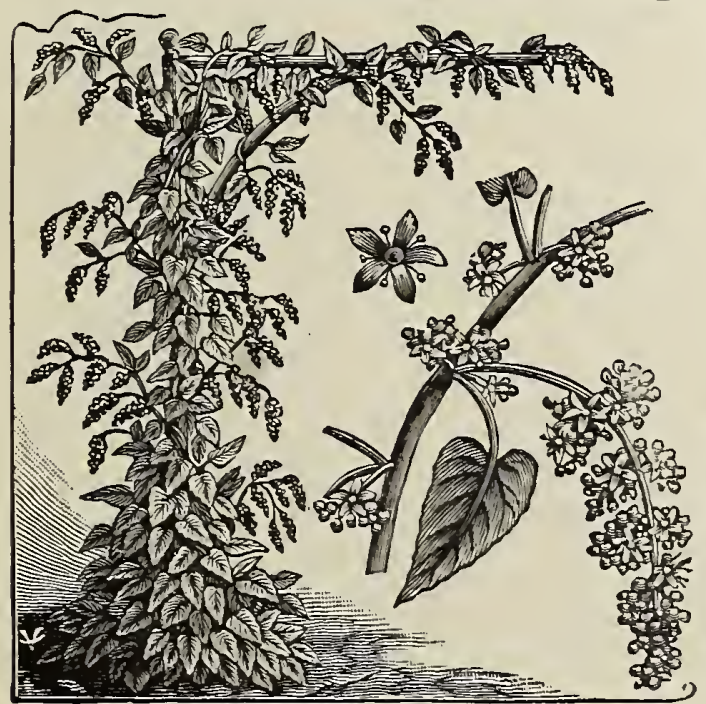

BALLOON VINE. point of perfection zet attained the flowers being of immense size and faultless in form, composed of the finest varieties and most brilliant and charming colors only. Pkt. 10c., trade pkt. 30c., oz. \$1.50.

\section{BALSAM APPLE (See Momordica)}

\section{BALLOON VINE}

A rapid-grcwing annual climber; succeeds besc in light soil and warm situation; flowers white; seed-vessels look like miniature balloons.

325 Balloon Vine (Cardiospermum) Pkt. 5c., trade pkt. 10c., oz. 20c.

\section{BEANS}

330 Scarlet Runner. Rapid climli. er, flery scarlet. Pkt. 5c., pint $20 \mathrm{c}$, by mail $30 \mathrm{c}$.

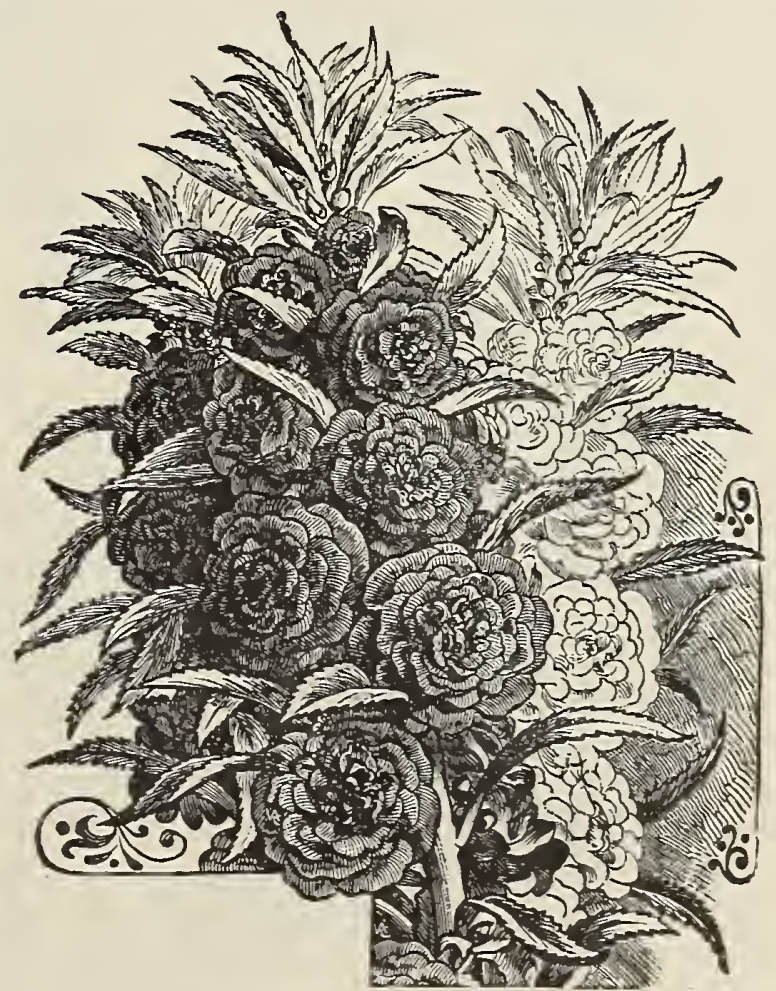

BALSAM, OR LADY SLIPPER. 


\section{BEGONIA}

340 Double Tuberous Rooted, prize mixed. Very large flowers ; unsurpassed quality. Pkt. 25c., trade pkt. $\$ 1.00$.

341 Single Tuberous Rooted, prize mixed. An unrivaled strain of curiously formed flowers saved from selected flowers of the largest and most bril liant colors only. Pkt. 15c., trade pkt. 50c.

342 Vernon Grandiflora Dwarf. A dwarf, compact habit, adapting it for many purposes for which the taller varieties are not suitable, such as edgings, etc. Large, bright red flowers. Pkt. 10c., trade pkt. 25c.

\section{BROWALLIA (Amethys}

Handsome annuals, with blue and white flowers completely studding the bushy plants during the whole summer; fine for garden beds in summer or pot culture in winter if sown in August. $1 \mathrm{ft}$.

371 B. Speciosa major. A beautiful new large-flowering variety of the most brilliant ultramarine blue, especially valuable as a pot plant for winter and early spring flowering. Excellent florist's flower. Pkt. 10c., trade
pkt. 25c.

372 Mixed Colors. Pkt. 5c., trade pkt. 15c., oz. 50c.

\section{BRYONOPSIS (Laciniosa Erythrocarpa)}

150 A beautiful summer climber with palmate ivy-like leaves of pale green color. Its yellow flowers are followed by pretty cherry-like green fruits, which change to bright scarlet, marbled with white. Very pretty for training over trellises, arbors, porches, fences, etc. The fruits are used for hair orn aments by the women of Japan. $10 \mathrm{ft}$. Pkt. 5c., trade pkt. 15c.

\section{CALCEOLARIA}

An ornamental plant, producing a mass of beautiful pocket-like flowers; a universal favorite for decorating the greenhouse or conservatory. Our strains can be relied upon to produce nothing but flowers of the largest size and most brilliant coloring.

400 C. Hybrida grandiflora pumila compacta. $1 \mathrm{ft}$. Pkt. 25c., trade pkt. $75 \mathrm{c}$.

405 C. Hybrida robusta grandiflora. Large, brilliant, self-colored and beautifully marked tigered flowers, mixed. Finest class for florists or exhibition purposes; an unrivaled strain. Pkt. 40c, half trade pkt. $60 \mathrm{c}$. , trade pkt. $\$ 1.00$.

$\$ 10$ Cactus. Choice mixed. Pkt. 10c., trade pkt. 35c.

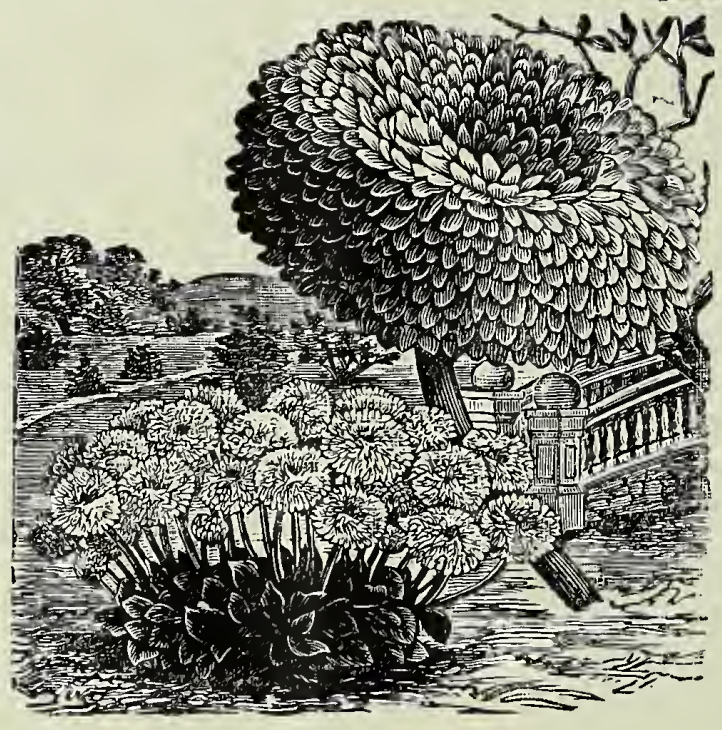

CALENDULA.

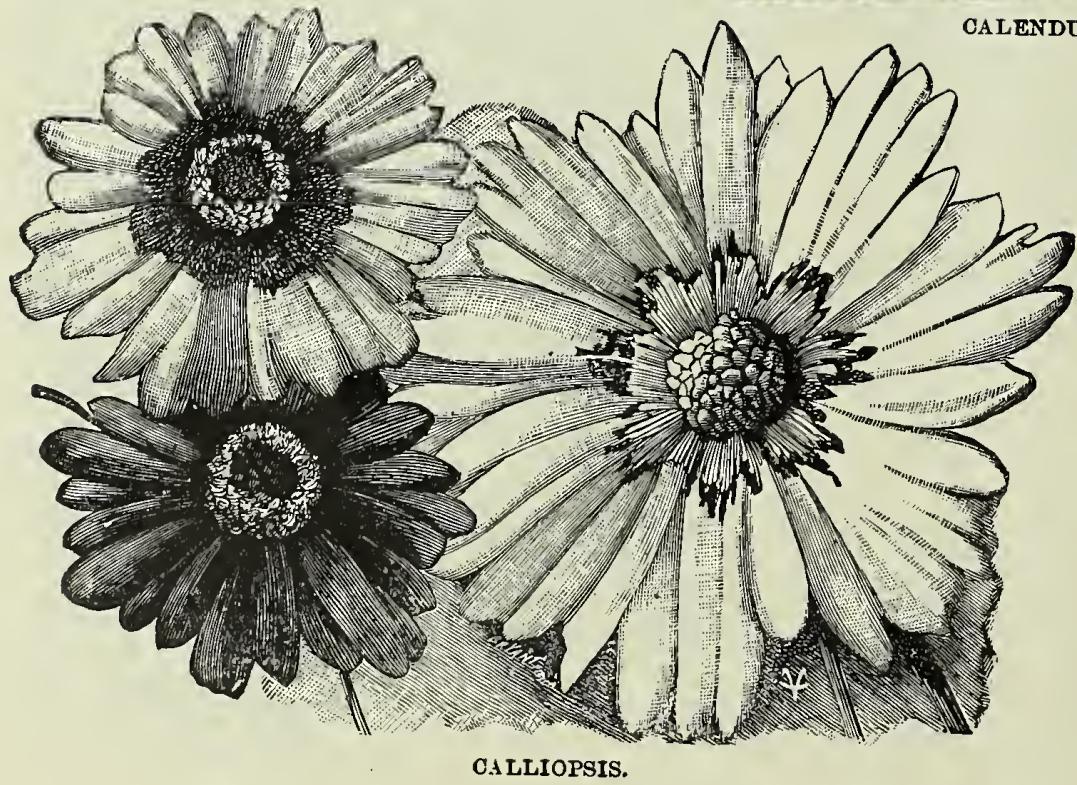

seed and spikes of brilliant flowers. Soak the hot water before planting; sow in sandy loam or peat, and place in a hotbed; when up to the second leaf, pot off singly and keep under glass until the proper season for planting out.

\section{Large-Flowered Dwarf French}

550 Madame Crozy. Dazzling scarlet, edged with golden yellow, very free bloomer and vigorous grower. Pkt. 10c oz $25 \mathrm{c}$

555 Choice mixed. Pkt. 5c., oz. 15c., $1 / 4$ lb. 40c., lb. $\$ 1.00$

\section{CALLIOPSIS, OR COREOPSIS}

These beautiful "Bright Eyes" are showy summer bedding annuals, with large bright flow ers borne in great profusion all summer long, and succeeding almost everywhere. They are elegant for garden decoration and fine cutting.

510 C. Lanceolata grandiflora. Very large flowers, averaging four inches across, of a bright golden yellow, produced in great profusion for a long period, fine for cutting, hardy, perennial; flower first year; $2 \frac{1}{2} \mathrm{ft}$. Pkt. $5 \mathrm{c}$., trade pkt. $15 \mathrm{c}$, , oz. $50 \mathrm{c}$.

512 Mixed. Very showy, brilliant yellow, brown velvety crimson, blotched and striped sorts, excellent for borders, bloom of long duration, thrive anywhere, should be in every garden ; this class embraces about twenty beautiful annual sorts; 1 to $2 \mathrm{ft}$. Pkt. 5c., trade pkt. 10c., 0z. 25c. 
High Class Seeds

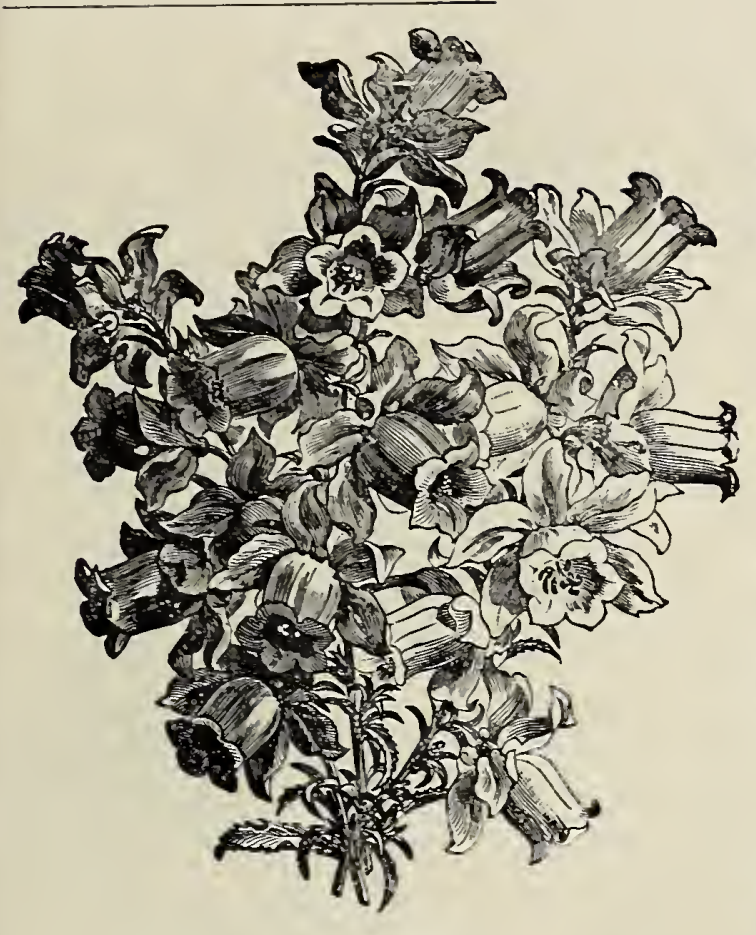

campanula.
115 Mulberry St., Newark, N. J.

\section{CAMPANULA (Canterbury Bells)}

Well-known, beautiful, hardy, herbaceous perennial, bearing a great profusion of attractive bell-fiowers; thriving best in light, rich soil; some varieties flower the first season if planted early.

523 C. Media, single, mixed (Canterbury Bell) ; 2t/2 ft. Pkt. 5c., trade pkt. 10c., oz. 35c.

524 C. Media, double, mixed (Double Canterbury Bell); 21/2 ft. Pkt. 10c., trade pkt.25c., oz. $\$ 1.50$.

\section{CANDYTUFT (Iberis)}

An old favorite, flowering profusely throughout the whole season; great farorite for beds, edgings, pots and borders; the plants are very fairly covered with blossoms, and of the easiest culture; 1 it. high.

\section{ANNUAL VARIETIES}

540 Giant White Perfection. Producing large, white trusses of branching habit, and very free-blooming; the finest annual sort for summer eutting. Pkt. 1Uc., trade pkt. $20 \mathrm{c} ., \mathrm{oz} .50 \mathrm{c}$.

$5 \pm 1$ Little Prince. The finest $d$ warf white. Pkt. 10c., trade pkt. 20c., oz. 50c.

542 Gem Hrbrids. Mixed. A new type candytuft, forming dense, bushy pyramidal plants, which form a mass of large, showy flowers, lasting a long time. We consider it the most desirable candytuft in cultivation and are sure that all who grow it will be delighted with its chaste beauty. The very best sort for pot culture or bedding; white, pink, crimson and lilac, mixed; 6 in. Pkt. 10c., trade pkt. 25c., oz. \$1.00.

543 Empress. White. Pkt. 5c., trade pkt. 10c., oz. 25c., lb. $\$ 2.00$.

514 Mixed. Crimson, purple, white, carmine and rose; fine early-blooming borderplants. Pkt. 5c., trade pkt. 10c., oz. 20c.

\section{HARDY PERENNIAL VARIETIES}

645 C. sempervirens. Profuse white blooming hardy perennial, coming in flower early in spring; much used for cemeteries, rockeries, etc; $1 \mathrm{ft}$. Pkt. 10c., trade pkt. 25c.

646 C. Gibraltarica. Very fine species, with white flowers, shading off to lilac. Pkt. 10c. trade pkt. $25 \mathrm{c}$.

\section{HARDY CARNATION}

Carnations are general farorites for their delicious fragrance and richness of colors. They are indispensable both for greenhouse culture in winter and for the garden in summer. 561 Giant Marguerite, Scarlet. Brilliant scarlet, extra double flowers; very desirable; 1 ft. Pkt. 10c., trade pkt. 50c., oz. \$3.00.

562 Giant Marguerite, White. Pkt. 10c., trade pkt. 40c., oz. \$2.50.

563 Giant Marguerite, Mixed. New perpetual flowering variety, blooming in four months from seed; beautiful colors of extra quality; very double and fragrant; $1 \mathrm{ft}$. Pkt. 5c., trade pkt. 25c., oz. $\$ 1.50$.

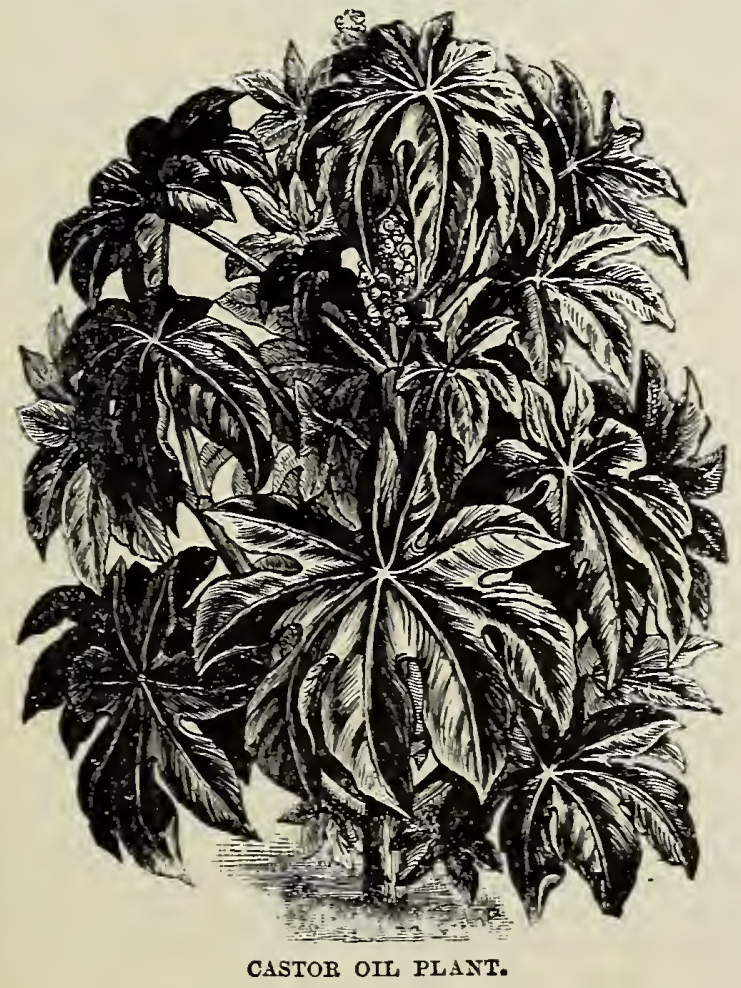

564 Double Early Flowering Dwarf Vienna. Fine mixed. Pkt. 10c., trade pkt. $25 \mathrm{c}$., oz. $\$ 2.50$.

\section{CANARY BIRD VINE}

530 Yellow flowers with ornamental foliage. A good winter blocmer in the greenhouse. It is one of the most beautiful of all climbers. its elegant foliage adding so much to the beauty of the blossoms, $10 \mathrm{ft}$. Pkt. 5c., trade pkt. 10c., oz. 50c.

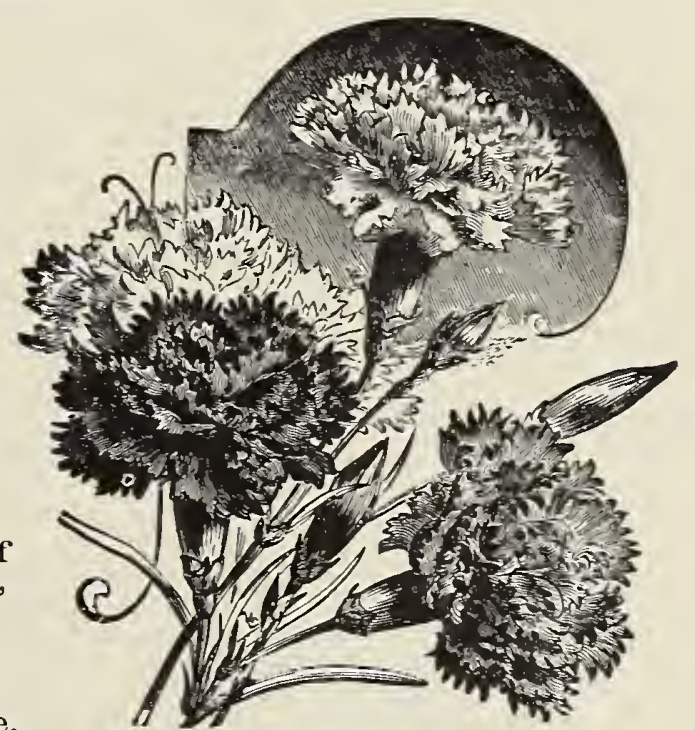

CARNATION.

\section{CASTOR OIL PLANT (See Ricinus) CELOSIA, OR COCKSCOMB.}

Very popular annuals of the easiest culture, producing large, ornamental, comb-like heads. Not only are they highly prized for summer flower-beds, but they make fine pot-plants, 5so Cristata, Giant Maxima, Dwarf. Bright crimson combs, dark foliage, the finest red. Pkt. 10c., trade pkt. 50c.

584 Cristata. Finest Mixed. Sared from selected combs. Pkt. 5c., trade pkt., 25c, 585 Plumosa Thompsoni Magnifica. Improved feathered cockscomb. A big improvement on Plumosa as the combs are much larger and broader and the colors are more brilliant. Pkt. 10c., trade pkt. $25 \mathrm{c}$.

\section{CENTAUREA CYANUS}

(Ragged Sailor, Cornflower or Blue Bottle)

A farorite annual. Largely used as a cut flower; 18 in.

603 Large-Flowered, Deep Blue. Pkt. 5c., trade pkt. 10c., oz. 25c.

606 Large-Flowered, Mixed. Six shades. Pkt. 5c., trade pkt. 10c., oz. 20c

607 Large-Flowered, Double Mixed. Pkt. 5c., oz. 30c. 


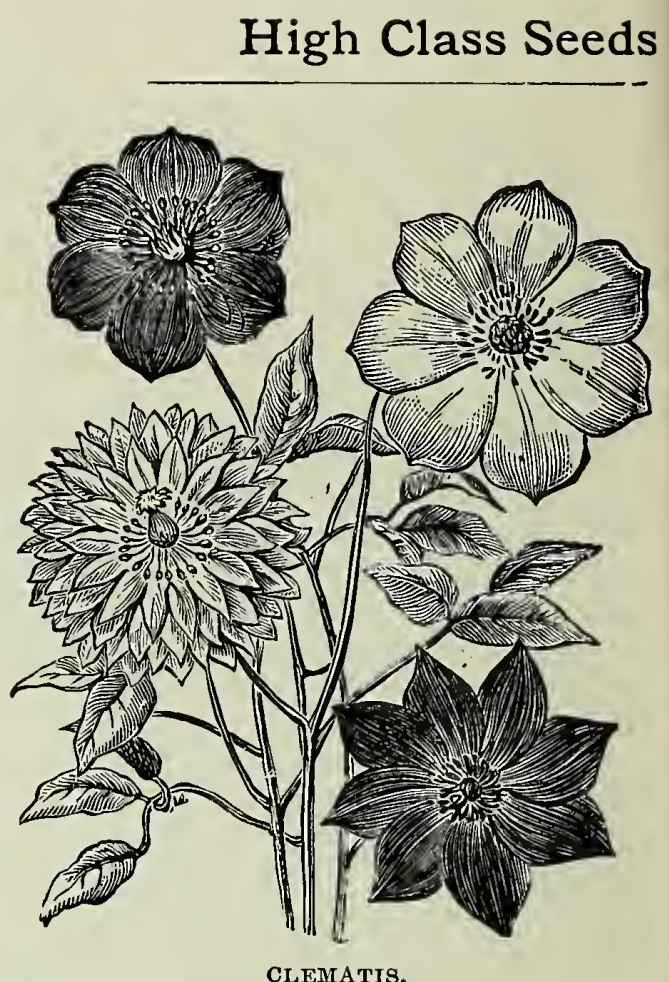

CENTAUREA ODORATA (Giant-Flowering Cornflowers)

These may be described as gigantic cornflowers, and are of the same easy culture, succeeding everywhere. But as cut flowers they are greatly in advance of the old Centaurea Moschata, the flowers being from two to four inches in diameter, of graceful form and sweetly scented. A sowing made out of doors in April, May and June will furnish an abundance of bloom throughout the summer. They can always be sown indoors in January or February for Easter flowering.

608 C. Chameleon. Pale yellow on opening, turning to a beautiful rose color. Pkt. 10c. 609 C. odorata. Light blue, highly fragrant. Pkt. 10c.

610 C. Margaritae. Snow-white blossoms. Pkt. 10c.

611 C. suaveolens (Yellow Sweet Sultan or Grecian Cornflower). Very showy, large, brightyellow flowers, sweetly scented. Pkt. 5c.

612 The Above Mixed. Pkt. 10c., trade pkt. 25c.

\section{CENTAUREA (White-Leaved "Dusty Miller")}

Fine for bedding, vases, hanging baskets and pots; extensively used for margins. Sow seed from December to April. Half-hardy perennials.

615 C. candidissima. Broad-cut foliage; 1 ft. Pkt. $10 \mathrm{c} ., 500$ s. $25 \mathrm{c} ., 1000 \mathrm{~s} .40 \mathrm{c} .$, oz. $\$ 1.50$. 616 C. gymnocarpa alba. Fine-cut foliage; $1 \frac{1}{2} \mathrm{ft}$. Pkt. 10c., trade pkt. 25c., oz. 60c.

\section{CHRYSANTHEMUM}

Showy and effective garden favorites. The hardy annuals are summer-flowering border plants; good for pot culture and quite distinct from the autumn-flowering varieties.

626 Choice Mixed. Single and double. Many beautiful sorts. Pkt. 5c., trade pkt. 10c., oz. 25c. 629 Chinese and Japanese Autumn-Flowering Varieties. This seed has been saved from a large, magnificent imperial collection; will bloom first year if sown early; hardy annual. Pkt. 10c., trade pkt. 50c.

\section{CLEMATIS (Japanese Virgin's Bower)}

Hawthorn-scented blossoms, a grand plant for piazzas, fences-in fact, any position where a climber is wanted. It is just the thing for covering terraces or embankments; does equally well in sunshine or shadow, and stands unrivaled as a plant for the cemetery.

660 C. paniculata. Autumn-blooming. Hardy perennial climbers; $25 \mathrm{ft}$. Pkt. 10c., trade pkt. 15c., oz. $\$ 1.50$.

661 Jackman's Flowering Hybrids. $15 \mathrm{ft}$. Pkt. 20c., trade pkt. 50c., oz. $\$ 2.50$.

\section{CLEOME PUNGENS (Giant Spider Plant)}

665 A robust plant, growing vigorously four to five feet high, unaffected by wind or weather, and flowering profusely for months. The flowers are very showy, with long, slender stamens, single petals measuring an inch across, and of a bright rose color. The long, slender seed-pods are carried upon still longer stipules, giving the effect of a many-legged spider, with the bright bunch of flowers as the head. It grows freely from seed, thrives luxuriantly, and blooms all summer. It is also one of the very best honey-producing plants. Pkt. 5c., trade pkt. 10c., oz. 35c.

\section{COBAEA}

Elegant, rapid-growing climbers, attaining a height of 20 to $30 \mathrm{ft}$ 680 C. Scandens (Blue). Pkt 10c., trade pkt. 15c., oz. 60c.

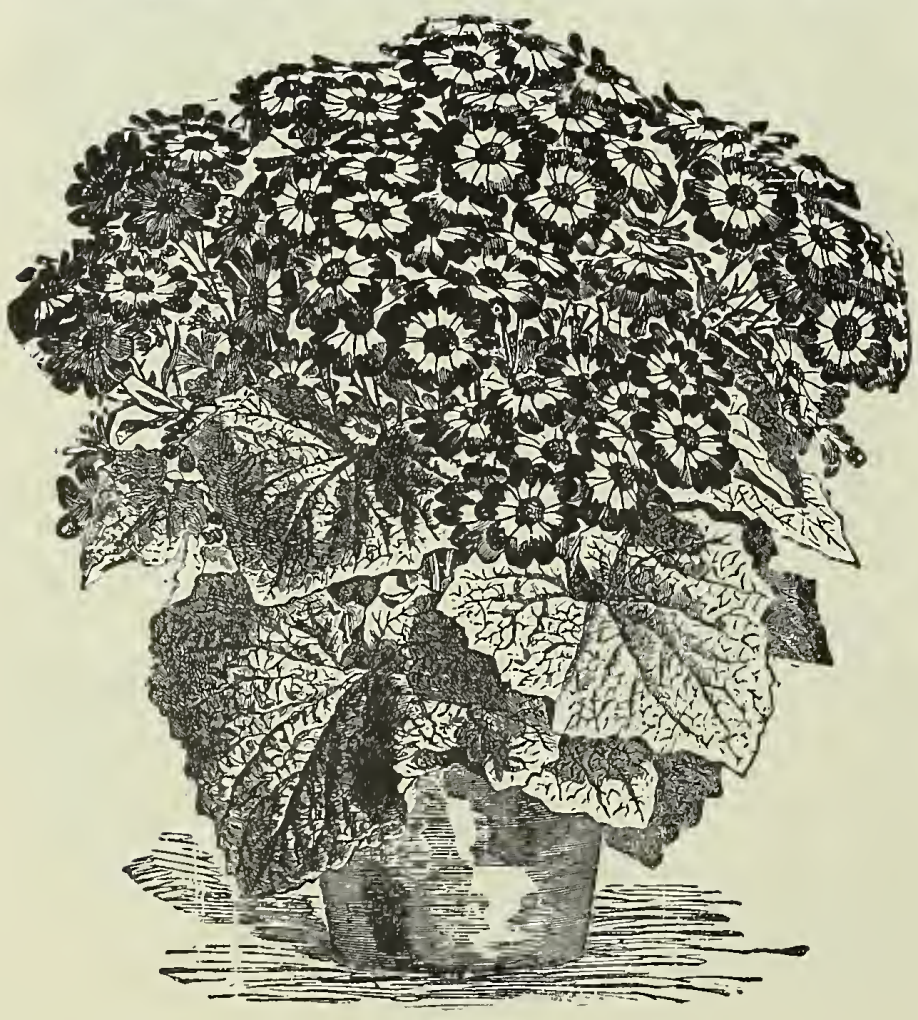

CINERARIA.

\section{CINERARIA}

Our strain of cineraria seed is unsurpassed for beautiful variety, richness of color, as well as perfection of form and large size of flower. They are unequaled for profusion of bloom, size of flower and general excellence.

633 Noll's Large-Fowering Half-Dwarf, Mixed. The finest class for florists. Pkt. 40c., trade pkt. $\$ 1.00$.

634 Choice Mixed. Pkt. 25c. trade pkt. 50c.

635 Stellata, Star Cineraria. Very profuse, small-flowering variety for cutting and decorating purposes. $3 \mathrm{ft}$. Pkt. $25 \mathrm{c}$., trade pkt. $\$ 1.00$.

\section{COFFEA ARABICA (Coffee-Tree)}

685 The coffee of commerce. Seeds should be sown in boxes indoors, about January or February, and planted out when all danger of frost is past. Pkt. 10c., 3 for 25c.

\section{COLEUS}

700 Finest Hybrids, mixed. Saved from a noted private collection of large-leaved sorts, with extraordinary and superbly rich markings. Pkt. 10c., trade pkt. 50c.

\section{COTTON}

711 The cotton plant is always interesting. particularly to the young people of the North. The larse yellow Hibiscus-like flowers are followed by pointed pods, which on coming to maturity burst and display a profusion of white down, which forms the cotton of commerce. In the North, if the seeds are started early in a hotbed or in the house, the plants will produce mature pods before frost. Pkt. 10c.

\section{ROYAL ENGLISH COWSLIPS}

712 Mixed. Hardy; one of the most beautiful early-blooming spring flowers; fine for beds or pots, producing large umbe s of magnificent flowers of intense brilliancy of color and great variety of marking, borne on stalks about 8 inches high. Many of the blooms are one inch across, of shades of crimson, maroon, lilac, pink, white, yellow, etc. Pkt. 10c., trade pkt. 50c. 


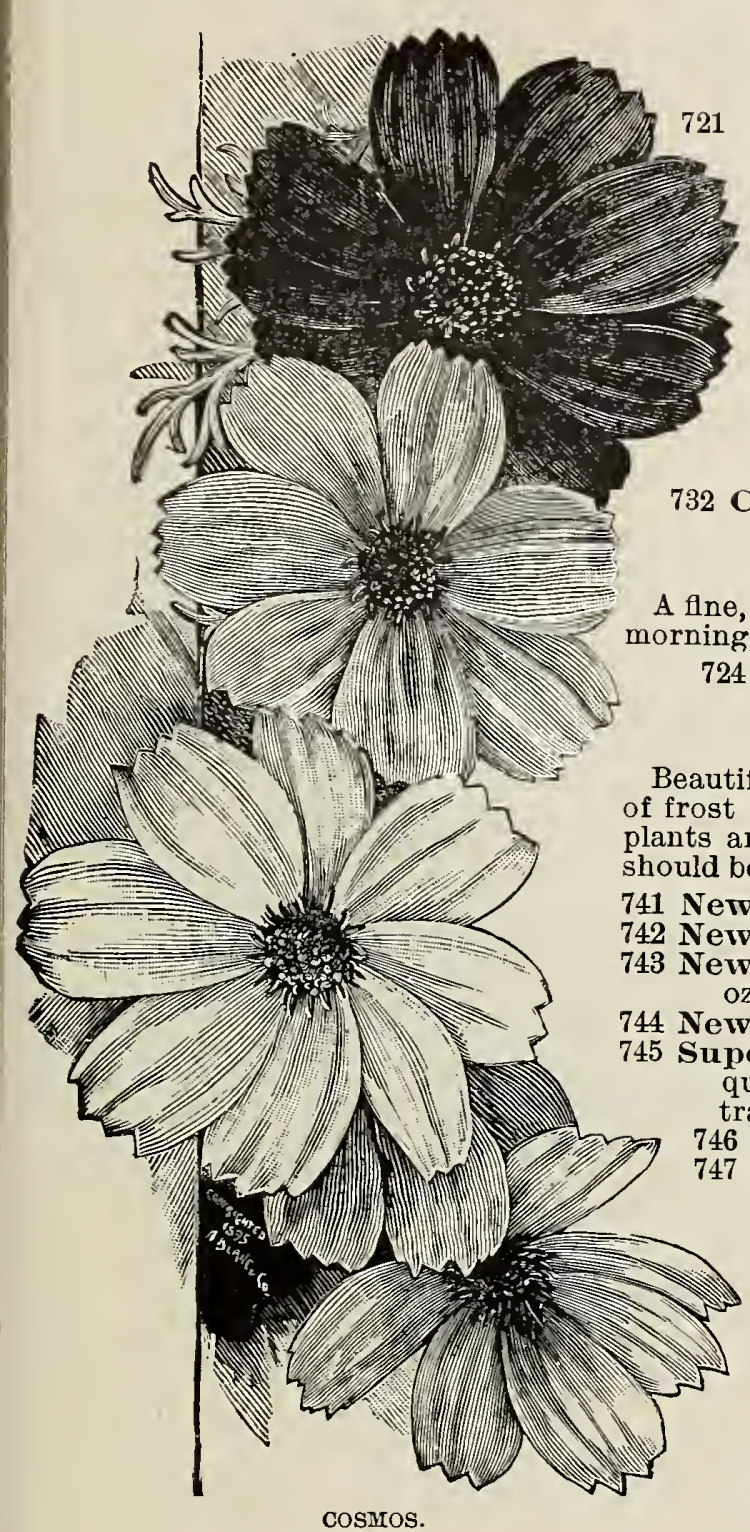

cosmos.

\section{CONVOLVULUS MAJOR}

(Imperial Japanese Morning Glory)

Mammoth Butterfly, Japanese and Chinese. Comprising 40 brilliant colored sorts; they are exceedingly vigorous in growth, decorative in foliage, which is of various shades of green and silvery lustre, frequently variegated, while the flowers are nearly always of immense size, frequently six inches across; entirely new colors, such as ashy grays, slate color, bronzy reds, browns, shades of sea green, blues bordered with red, purples marbled with black, whites spotted with blue, flamed, streaked, marbled, fringed edges, and all of incomparable beauty. The double-flowering sorts are really superb and can hardly be described; 20 ft. Pkt. 10c., trade pkt. 15c., oz. 75c.

\section{CONVOLVULUS MINOR (Dwarf Morning Glory)}

They do not climb, but form bushy plants, which area perfect mas. of flowers. Hand. some for baskets or borders, producing a very brilliant effect; $1 \mathrm{ft}$.

732 C. Tricolor, Finest mixed. 15 finest sorts. Pkt. 5c., trade pkt. 10c., oz. 15c.

\section{CLIMBING MORNING GLORY}

A flne, hardy and rapid grower, which always gives great satisfaction. They bloom early in the

724 Fine Mixed. 25 fine varieties. Pkt. 5c., trade pkt. 10c., oz. 15c.

\section{COSMOS}

Should be sown in spring in the open ground, when danger f frost is past, or the seed may be started under cover and afterward transplanted. When the should be continued until the middle of July.

41 New Mammoth-Flowering, Pearl. A new beautiful white. Pkt. 5c., trace pkt. 15c., oz.60c. Mammoth-Flowering, Pink. Pkt. 5c., trade pkt. 15c., oz. 60c. oz. $60 \mathrm{c}$.

744 New Mammoth-Flowering, Yellow. Pkt. 10c., trade pkt. 20c., oz. \$1.50.

45 Superb, New Mammoth-Fiowering. New; flowers three to five inches across; in exquisitely beautiful shades of pink, crimson, red, white, yellow and dark maroon. Pkt. 10c., trade pkt. 30c., oz. $\$ 1.00$.

746 Large-Flowering, Choice Mixed. Pkt. 5c., trade pkt. 10c.. oz. 25c.

747 Early Summer-Fiowering Cosmos. The cosmos has developed into one of our most beautiful garden annuals, and has been appropriately called "The Glory of Autumn" Unfortunately they do not bloom until quite late and sometimes in colder Northern States early frost catches them before they are fully in flower. This new strain of early-flowering cosmos, which we have been working up for several years, begins to bloom scatteringly in June, the quantity increasing gradually until August, and from that time until frost the plants are a mass of flowers. The plants are dwarfer than the late-flowering cosmos offered above, forming compact bushes only four feet high. The colors are white, crimson and pink, which we offer only in mixture.

Mixed Colors. Pkt. 10c., trade pkt. 25c., oz. 60c.

\section{CYCLAMEN PERSICUM GIGANTEUM}

Charming plants with beautiful foliage and rich-colored fragrant flowers; universal favorites for winter and spring blooming. This famous strain of giganteum varieties have large leaves and stout flower stalks, throwing the flowers well above the foliage, and cannot be excelled.

770 C. Alba, Pure White. 100 seeds $\$ 1.00$.

771 C. alba rubrum. White, red eye. 100 seeds $\$ 1.00$.

772 C. Purple King, Dark Red. 100 seeds $\$ 1.00$.

773 C. roseum, Pink. 100 seeds $\$ 1.00$.

776 C. gigantum, Mixed. 100 seeds 75 c., 1,000 seeds $\$ 6.00$.

777 C. persicum, Mixed. Pkt. 10c., 100 seeds 40c., 1,000 seeds $\$ 2.50$.

\section{CYPRESS VINE (Ipomøa Quamoclit)}

One of our most popular vines, with very delicate fern-like foliage, and masses of beautiful, small, star-shaped flowers; annual; $15 \mathrm{ft}$.

780 Crimson. Pkt. 5c., trade pkt. 10c., oz. 25c.

781 White. Pkt. 5c., trade pkt. 10c., oz. 25c.

782 Mixed. Pkt. 5c., trade pkt. 10c., oz. 25c.

\section{CYPERUS}

785 Alternifolius (Umbrella Plant). Pkt. 10c., trade pkt. 40c.

\section{DAHLIAS}

790 Large-Flowering, extra double mixed. Saved from the largest and handsomest sorts only; $4 \mathrm{ft}$. Pkt. 10c., trade pkt. 50c.

791 Tom Thumb, extra double. Bouquet of Lilliputian, seed saved from the brightest colors only; 2 ft. Pkt. 10c., trade pkt. $30 \mathrm{c} ., 1 / 4$ Oz. $75 \mathrm{c}$.

792 Cactus Dahlia, double. Mixed colors. Quilled and curved petals, gracefully arranged in large heads of bloom. Pkt. 10c., trade pkt. 25c.

793 California Giants, single mixed. Composed of the rarest and brilliant colors only; $3 \mathrm{ft}$. Pkt. 10c., trade pkt. 25c.

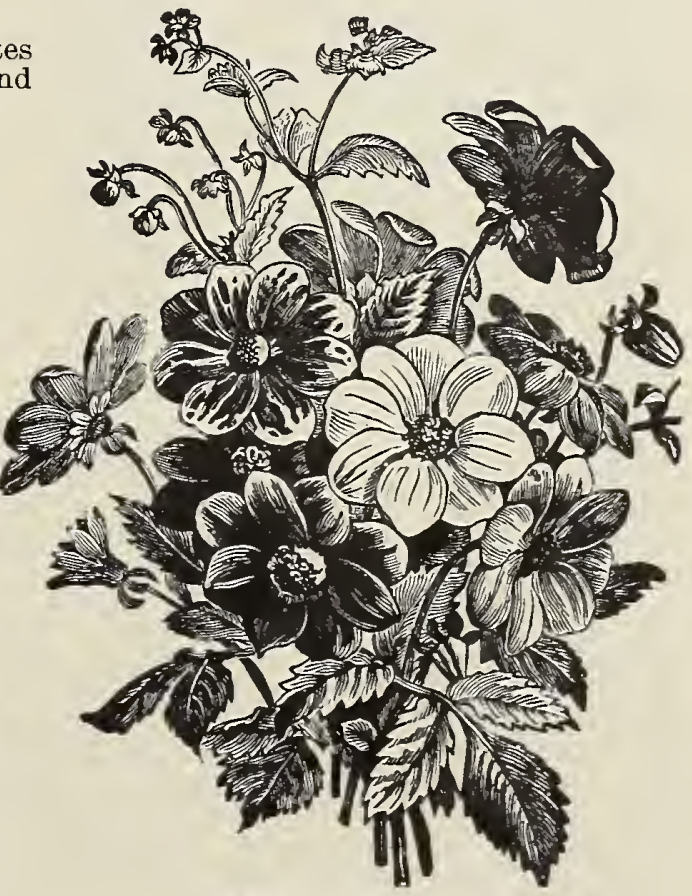

CLUSTER OF SINGLE DAHIIAS. 


\section{DAISY (Bellis Perennis)}

A favorite plant, in bloom from April to June. The seed we offer is saved from the flnest flrstquality double flowers only. Daisies can be easily raised from the seed sown in the spring.

800 Double Giant, Red. Flowers densely double and unusually large, glowing red, shaded rose. Pkt. 10c., trade pkt. 50c., $1 / 4$ oz. $75 \mathrm{c}$.

801 Double Giant, White. Unusually large double, pure white. Pkt. 10c., trade pkt. 50c., 1/4 oz. $\$ 1.00$.

802 Snowball. Excellent white variety. Pkt. 10c., trade pkt. 50c., 1/4 oz. $\$ 1.25$.

803 Giant Double Mixed. Very large densely double flowers; extra quality. Pkt. 15c., trade pkt. 50c., $1 / 4$ oz. $\$ 1.00$.

804 Choice Double Mixed. Extra quality large flowers. Pkt. 10c., trade pkt. 40c., 1/4 oz. 75c, oz. $\$ 2.50$.

\section{THE SHASTA DAISY (New Hardy Perennial)}

806 An excellent perennial to be used either as a bedding plant or for cut flowers. The seeds germinate readily, plants grow fast and are free bloomers. The flowers measure three and one-half to four inches across and are borne on stems 18 inches to two feet long. They have two rows of long, broad white petals and a yellow center. It is a wonderfully effective bedding plant, blooming all through the spring and summer months. The flowers will keep in

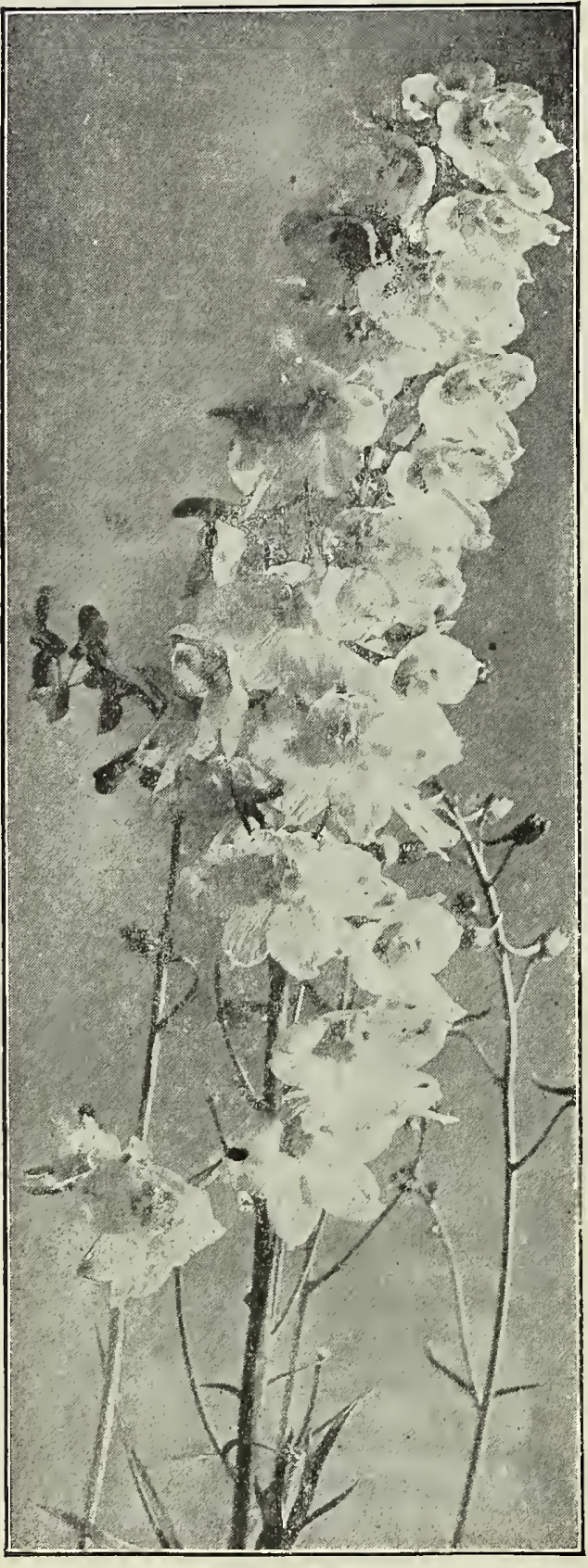

DELPHINIUM water for two weeks. Seed should be sown early in boxes indowrs and transplanted. Pkt of 15 seeds $15 \mathrm{c}$., trade pkt. $50 \mathrm{c}$.

\section{DATURA (Angel Trumpet)}

The Datura is a very interesting plant; branches freely, producing large trumpet-shaped flowers a foot or more in length. Sow seed in the open ground, or start early in pots and transplant; will bloom until
frost; annual.

810 D. Cornucopia (Horn of Plenty). A magnificent variety: stems dark purplish maroon. The flowers average five inches across the mouth, the interiors being glistening French
white, with purplish exteriors. Delightfully white, with purplish exteriors, 1
fragrant. Plkt.10c., trade pkt. 20c.

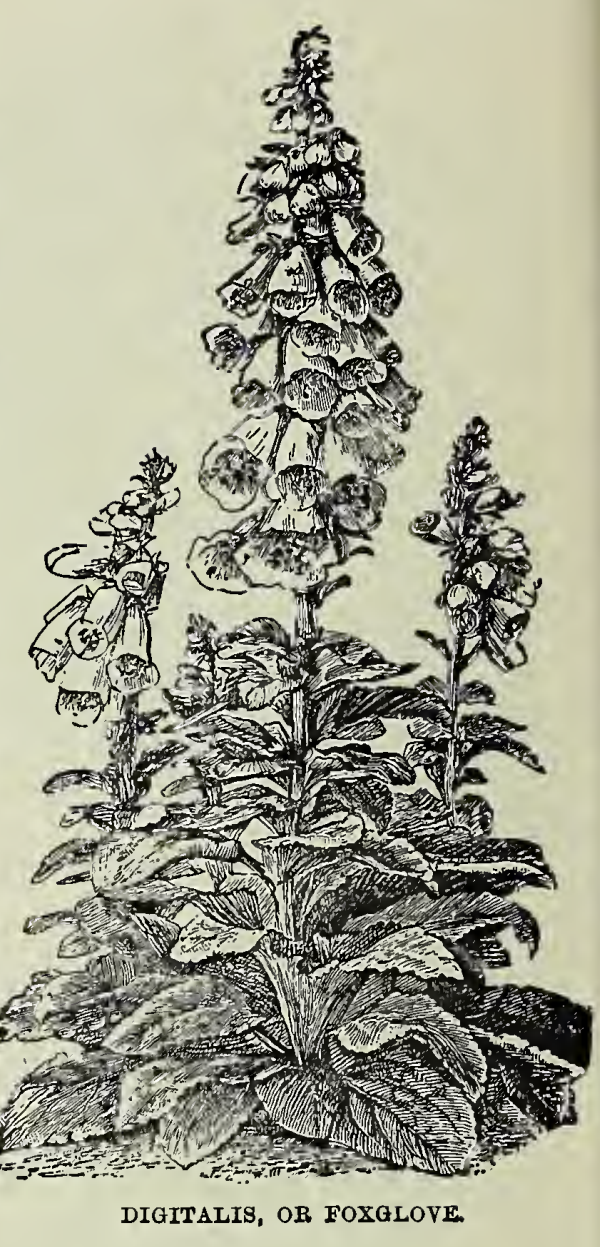

\section{DELPHINIUM (Perennial Larkspur)}

One of our most showy and useful plants, possessing almost every requisite for the adornment of the garden; producing splendid spikes of flowers in profusion throughout the summer. If sown early they bloom the first year from seed.

821 D. formosum. Brilliant blue, white center; $2 \frac{1}{2} \mathrm{ft}$. Pkt. 10c., trade pkt. 25c.

822 Hybridum, Double Mixed. Choicest varieties only; very fine quality. Will bloow the first year if sown early. Pkt. 10c., trade pkt. 50c.

\section{DIANTHUS OR PINKS}

The family of "Pinks" is unrivaled for brilliancy and rich variety of color; the plants are bushy, of symmetrical form-blooming so profusely as to almost uninterruptedly cover the plants until late in the autumn, rendering them one of the most beautifuland satisfactory of all annuals for summer flower gardens. Height about one foot.

840 Single Annual. Finest Mixed. Pkt. 5c., trade pkt. 15c.

841 Double Annual. Finest Mixed. Pkt. 10c., trade pkt. 25c.

842 Double Perennial. Finest Mixed. Pkt. 10c., trade pkt. 35c.

\section{DIGITALIS (Fox Glove)}

These, the well-known Fox Gloves, are one of the finest June flowers. Spikes of bloom two feet long are produced in abundance and are very fine; perennial.

861 D. gloxiniaflora. Mixed. Beautiful gloxinia, spotted white, purple, rose and yellow flowers, all extra fine large sorts; $3 \mathrm{ft}$. Pkt. 5c., trade pkt. 10c., oz. 50c.

\section{DRACAENA (Excellent Vase Plant)}

871 D. australis. Long, drooping, graceful foliage. Trade pkt. 25c., oz. \$1.00.

872 D. indivisa. Green foliage. Pkt. 5c., trade pkt. 15c., oz. 40c.

\section{ECHINOCYSTIS (Wild Cucumber Vine)}

900 Lobata. One of the quickest growing vines we know of; splendid for covering trellises. old trees and fences. Pkt. 5c., oz, 50c. 


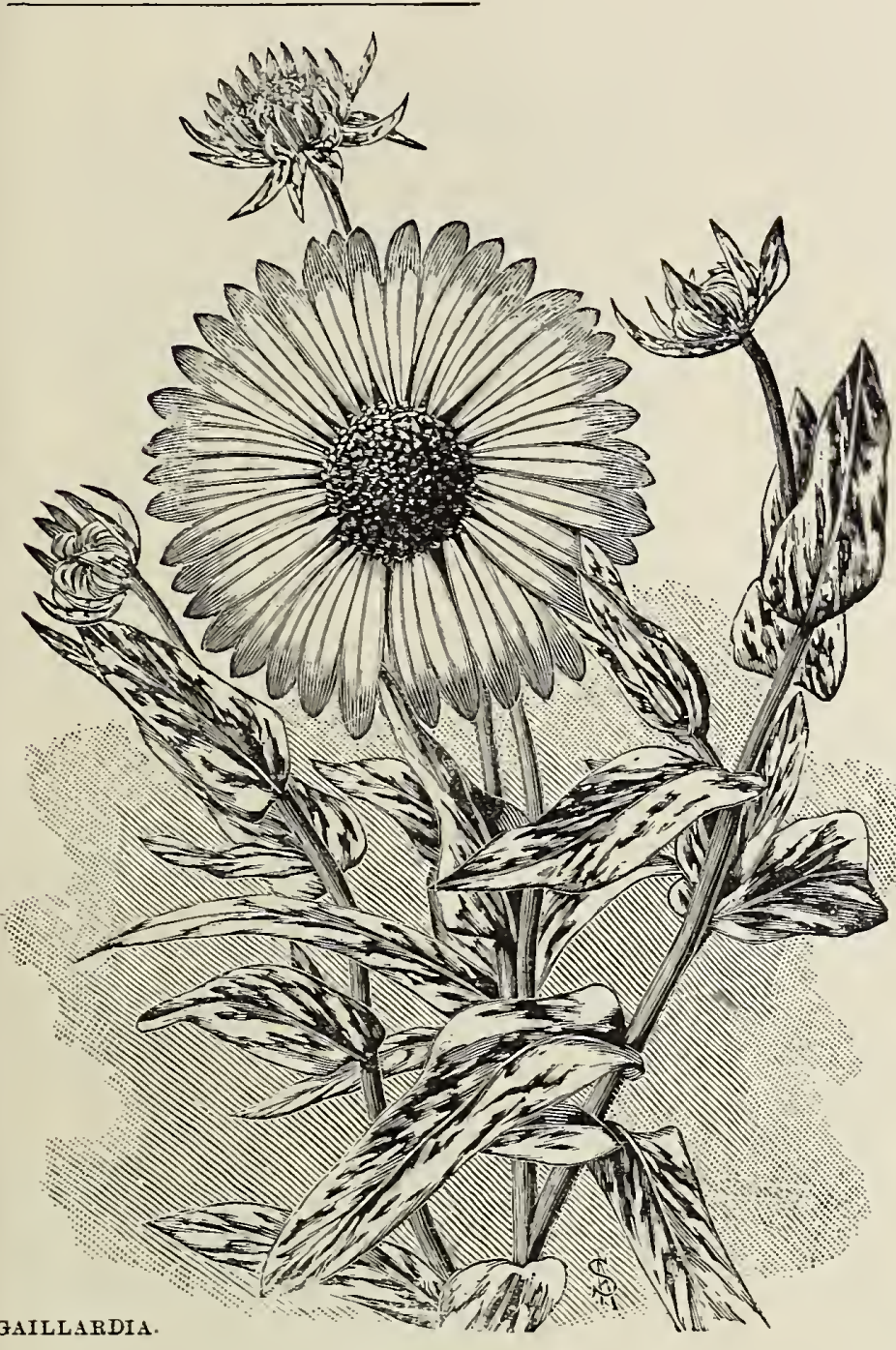

FERNS

960 Extra choice mixed. Pkt. 25c., trade pkt. $\$ 1.00$.

\section{GERANIUM}

991 Large-Flowering Scarlet. Pkt. 10c., trade pkt. $25 \mathrm{c}$.

\section{GODETIA (Satin Flower)}

An attractive hardy annual, deserving more extensive cultivation. The plants bloom profusely and bear showy flowers, three to four inches across, of white, rose, crimson, lilac and spotted; $1 \frac{1}{2} \mathrm{ft}$.

1033 G. grandiflora, finest, mixed. Comprising thirty handsome, large-flowered varieties. Pkt. כ̌c., trade pkt. 15c., oz. $50 \mathrm{c}$

\section{GOURDS (Ornamental)}

A large and interesting class, producing a great variety of curious fruits, many of which are peculiarly marked. All the fruits are hard-shelled, and will keep for years, exciting much attention.

1051 Dipper Shaped (Calabash). Pkt. 5c., trade pkt. 10c., oz. 30c.

1052 Egg Shaped (Japanese Nest Egg Gourd). Pkt. 5c., trade pkt. 10c., oz. 30c. 1053 Hercules' Club. Club shaped; 4 ft. long. Pkt. 5c., trade pkt. 10c., oz. 30c.

ıvot Orange Shaped. Mock Orange. Pht. 5c., trade pkt. 10c., oz. 30c.

1057 Sponge or Dish Rag. (Chinese Luffa). Pkt. 5c., trade pkt. 10c., oz. 30c.

1058 Choice Mrixed. Including all the above; also gooseberry, lemon, apple, onion and pear varieties. Pkt. 5c., trade pkt. 15c., oz. 40c.

\section{HELICHRYSUM (The Eternal Flower)}

Valuable everlasting for winter bouquets.

1092 H. grandiflorum, Mixed. Comprising the brightest colored sorts only; $1 \frac{1}{2}$ ft. Pkt. 5c., trade pkt. $15 \mathrm{c} .$, oz. $50 \mathrm{c}$.
115 Mulberry St., Newark, N. J. annual; $1 \mathrm{ft}$.

910 E. californica. Beautiful, large, rich yellow. Pkt. 5c., trade pkt.

Golden IVest Flowers measure three and one half to icross, and are bright yellow and orange. Some flaring wide open, some saucer-shaped, others very deep, with Hlower, in others it runs into the yellow in fine penciled lines. Gorgeous beyond description. Pkt. 10c., trade pkt. 25c., oz. \$1.00.

Rose Queen. Pink, very fine. Pkt. 5c., oz. $\$ 1.00$.

914 Double White. Pure white. Pkt 5c. oz, 50c.

915 Double Pink. Beautiful shade. Pht. 10c., oz. $\$ 1.50$.

16 Single and Double, Mixed. Handsome colors only. Plit. 5c., trade pkt. 15c., OZ. 40c.

EUPHORBIA (Snow on the Mountain)

and margined white; annual; $2 \mathrm{ft}$. Plit. 5c., trade pkt. $10 \mathrm{c}$, veined

\section{GAILLARDIA}

Very showy and worthy a place in every garden, though they are as yet little cultivated. They always attract attention by their gay colors; $1 \frac{1}{2} \mathrm{ft}$. picta Lorenziana. Very free flowering, extra double, large round heads composed of 30 to 50 flowers; fine shades of orange, pkt. 15c., oz. 50c.

\section{HARDY PERENNIAL VARIETIES}

grandiflora compacta. New compact growing variety

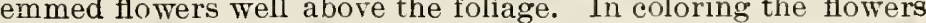
are as rich and varied as those of the tall-growing sort. Pkt.10c., trade pkt. 25c.

\section{FUCHSIA (Lady's Eardrops)}

The house cr shady situations in the garden. The seed we offer is saved from the finest to and double named sorts. Pkt. 25c.

GOMPHRENA (Bachelor`s Button)

Globe-shaped, everlasting flower; fine for borders.

White. Pkt. 5c., trade pkt. 10c., oz. $25 \mathrm{c}$

1041 Pink. Pkt. 5c., trade pkt. 10c., oz. 25c.

1043 Striped. Pkt. 5c., trade pkt. 10c., Oz. 25c.

1044 Mixed. Pkt. 5c., trade pkt. 10e., oz. 25e.

\section{GYPSOPHILA}

Pretty free-flowering, elegant plants for rock-work, baskets, edgings and borders. hardy perennial ; $2 \mathrm{ft}$. Pkt. 5c., trade pkt. $15 \mathrm{c} .$, oz. 40c.

1081 Elegans, Mixed. Hardy annual. Pkt. 5c., trade pkt. 10c., oz. 25 c.

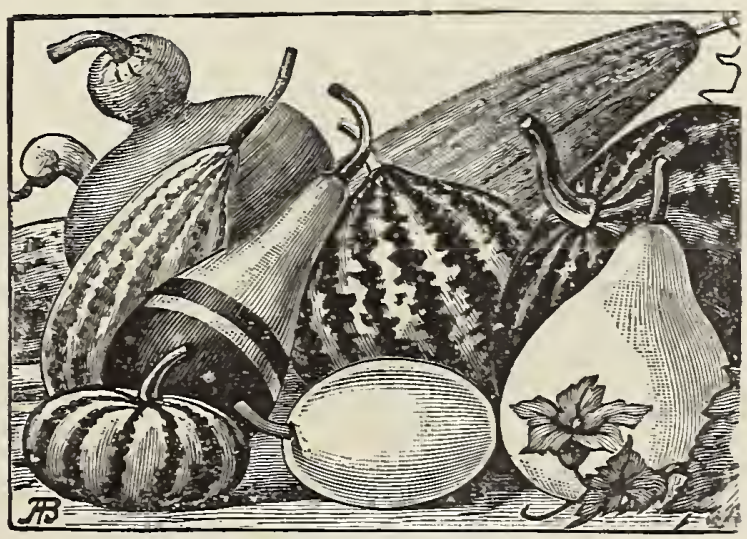

ORNAJIRTAL GODRDS. 


\section{HELIOTROPE}

A half-hardy perennial, flowering during the whole season; its delightful perfume makes it a most desirable bouquet flower.

1100 Lemoine's Giant. Originated with the famous French hybridizer. Of robust growth and produces heads of flowers double the size of the old sort. Pkt. 10c., trade pkt. 50 c.

1101 Fine, Mixed. From a large collection; 2 ft. Pkt. 5c., trade pkt. 25c.

\section{HOLLYHOCK (Hardy Perenuial)}

The seed offered has been saved from strong healthy plants, and from the finest double flowering strain.

1132 Pure White. Pkt. 10c., trade pkt. 30c.

1133 Pink. Pkt. 10c., trade pkt. 30c.

1134 Salmon Rose. Pkt. 10c., trade pkt. 30c.

1135 Scarlet. Pkt. 10c. trade pkt. 30c.

1136 Yellow. Pkt. 10c, trade pkt. 30c.

1137 Noll's Selected, Mixed. An excellent strain containing only the large-flowering, full double varieties of the brightest colors. Pkt. 10c., trade pkt. $30 \mathrm{c}$.

1138 Choice Double, Mixed. Pkt. 5c , trade pkt. 20c., oz. $\$ 1.00$.

\section{HYACINTH BEAN}

1150 Dolichos, Mixed. Climber; white and purple; $10 \mathrm{ft}$. Pkt. 5c., trade pkt. 10c., oz. 20c.

\section{HUMULUS, or JAPAN HOP}

1110 H. variegata. Rapid summer climber, in three or four weeks time attaining a height of $2 v$ to 30 feet, resembling the common Hop, but, being an annual, attains full perfection the first season. The leaves are green, blotched white, and they make a dense covering. Heat, drought and insects do not trouble it. Pkt. 10c., oz. 50c.

\section{ICE PLANT (See Mesenbryanthemum)}

\section{IPOMOEA}

Climbers of rapid growth, with beautiful and varied flowers; for covering old walls, trellises, arbors or stumps of trees they are invaluable.

1183 Hybrid Moon Flower. The most rapid growing of all annual climbing vines. The vines are literaliy covered with thousands of immense, pure white fragrant flowers, many of them measuring over seven inches across. Pkt. 10c., trade pkt. 20c., Oz. 50c., lb. $\$ 6.00$.

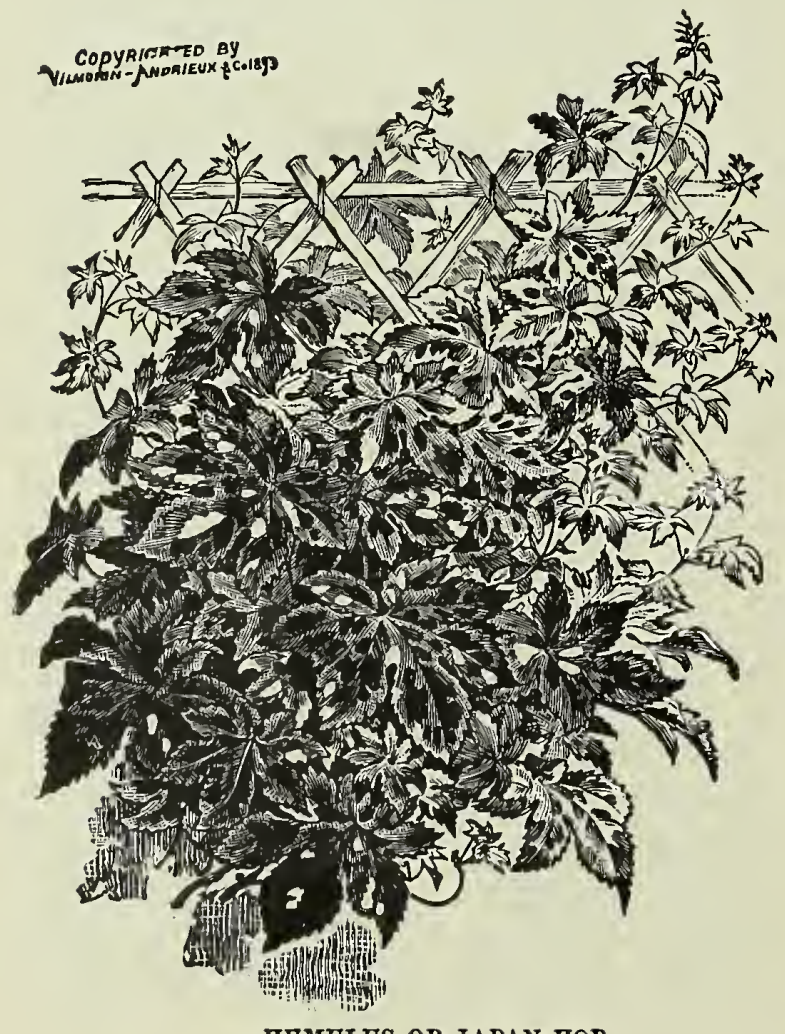

HOMULUS OR JAPAN HOP.

\section{IMPATIENS (French Lady Slipper)}

Most beautiful and useful flowering plant, producing waxy bright flowers almost continually, winter and summer; tender perennial.

1170 I. Sultana Hybrids. Brilliant rose, pink and scarlet flower; $1 \mathrm{ft}$. Pkt. 10c., trade pkt. 50c.

\section{KENILWORTH IVY}

A charming, small, neat, hardy perennial, trailing plant, blooming flrst year; suitable for baskets, vases, pots and rock-work; clings to walls, etc.

1220 Linaria cymbalaria ericoides. Lavender, white and purple. Very large-flowering sort. Pkt. 10c., trade pkt. 30c.

\section{LANTANA}

One of the most desirable half hardy, perennial greenhouse or bedding plants, constantly in bloom, verbena-like heads, and changing in hue; 2 to $5 \mathrm{ft}$.

1230 Large-flowering $\mathbf{H y}$ brids, M i $x$ e d. Pkt. 10c., trade pkt. 15c.,oz. 30c.

LATHYRUS

(Hardy or Everlasting Pea)

A beautiful, hardy climber, resembling the sweet pea, growing six to eight feet high when trained on a trellis; the flowers are borne in large clusters. 1250 L. latifolius. White. Pkt. 10c., trade pkt. 15c., Oz. 40c.

1251 L. latifolius. Scarlet. Pkt. 10c., trade pkt. 15c., oz. 40c.

1252 L. latifolius. Mixed. White rose and scarlet; 5 ft. Pkt.5c., trade pkt. 10c., oz. 25c.

\section{LARKSPUR}

Popular annuals for summer garden decorations. The splendid flowers are of varied colors and are borne on long spikes; blooming within a few weeks' time.

1253 Giant Rocket, Mixed. A much improved type, the flowers being larger than the old varieties, very double and the colors very beautiful, comprising white, rose, gray, red, violet, indigo, etc. Pkt. 5c., trade pkt. 30c. For Perennial Varieties, see Delphinium.

\section{LAVENDER}

1265 L. fragrans. An ornamental hardy perennial, bearing long spikes of fragrant blue flowers; 1 to $2 \mathrm{ft}$. Pkt. 5c., oz. $15 \mathrm{c}$.

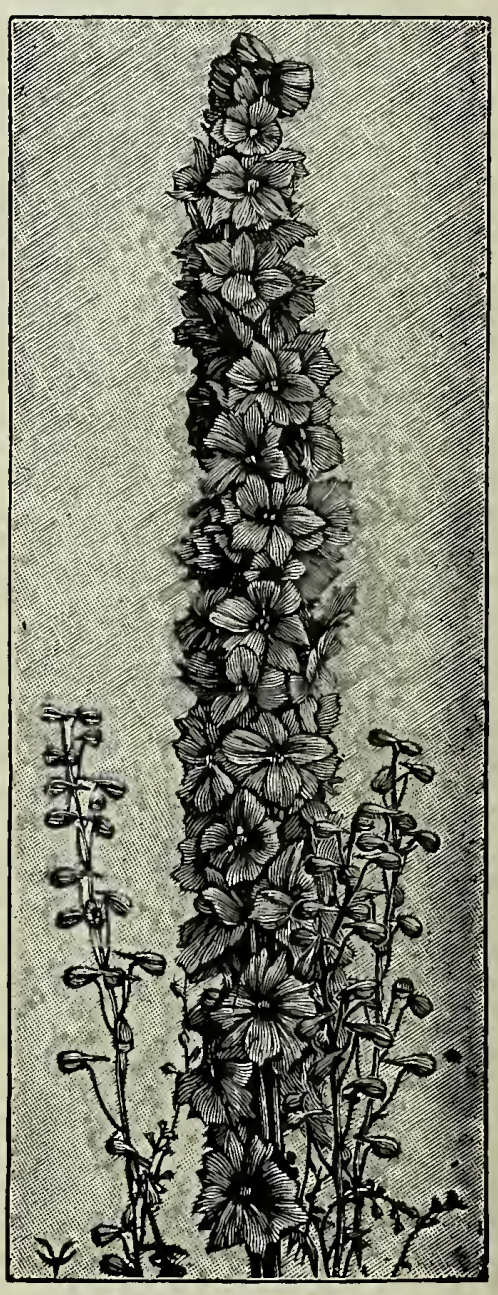

PEHETNIAT TARETOR 


\section{MIMULUS (Monkey Flower)}

Mimulus makes admirable pot plants, and equally adapted for beds in the garden, in semi-sunny positions. The colorings and markings are rich in the extreme, ranging through velvety crimson-maroon, yellow, white and pink, spotted and blotched in a beautiful manner. 1430 Mammoth Perfection, Mixed. New; very large-flowered, tigered and spotted; unequaled for large size and brilliancy of colors; very beautiful; $1 \mathrm{ft}$. Pkt. 10c., trade pkt. 30c.

\section{MUSK PLANT}

1434 Mosehatus eompactus. Best for pots and borders. Pkt. 10c., trade pkt. 30c.

\section{MYOSOTIS (Forget-Me-Not)}

Neat and beautiful little plants, succeeding best in a shady, moist situation. Half-hardy perennials, blooming the first year from seed if sown early.

1480 M. robusta grandiffora. Very large, bright blue flowers, pyramidal habit; 10 in. Pkt. 10c., trade pkt. 30c.

1481 M. al pestris Vietoria. Of bushy habit, bearing large, bright blue flowers. The plant attains a diameter of 8 to 10 ins., and when fully grown is globular in shane and periectly covered with flowers. Pkt. 10c., trade pkt. 30c., oz. $\$ 1.50$.

1482 M. palustris semperforens grandiflora. The most desirable sort for cutting, greenhouse use or summer flowering. Pkt. 10c., trade pkt. 50c., oz. $\$ 3.00$.

1485 Mixed. All sorts. Pkt. 5c., $1 / 4$ oz. 20c., oz. 60c.

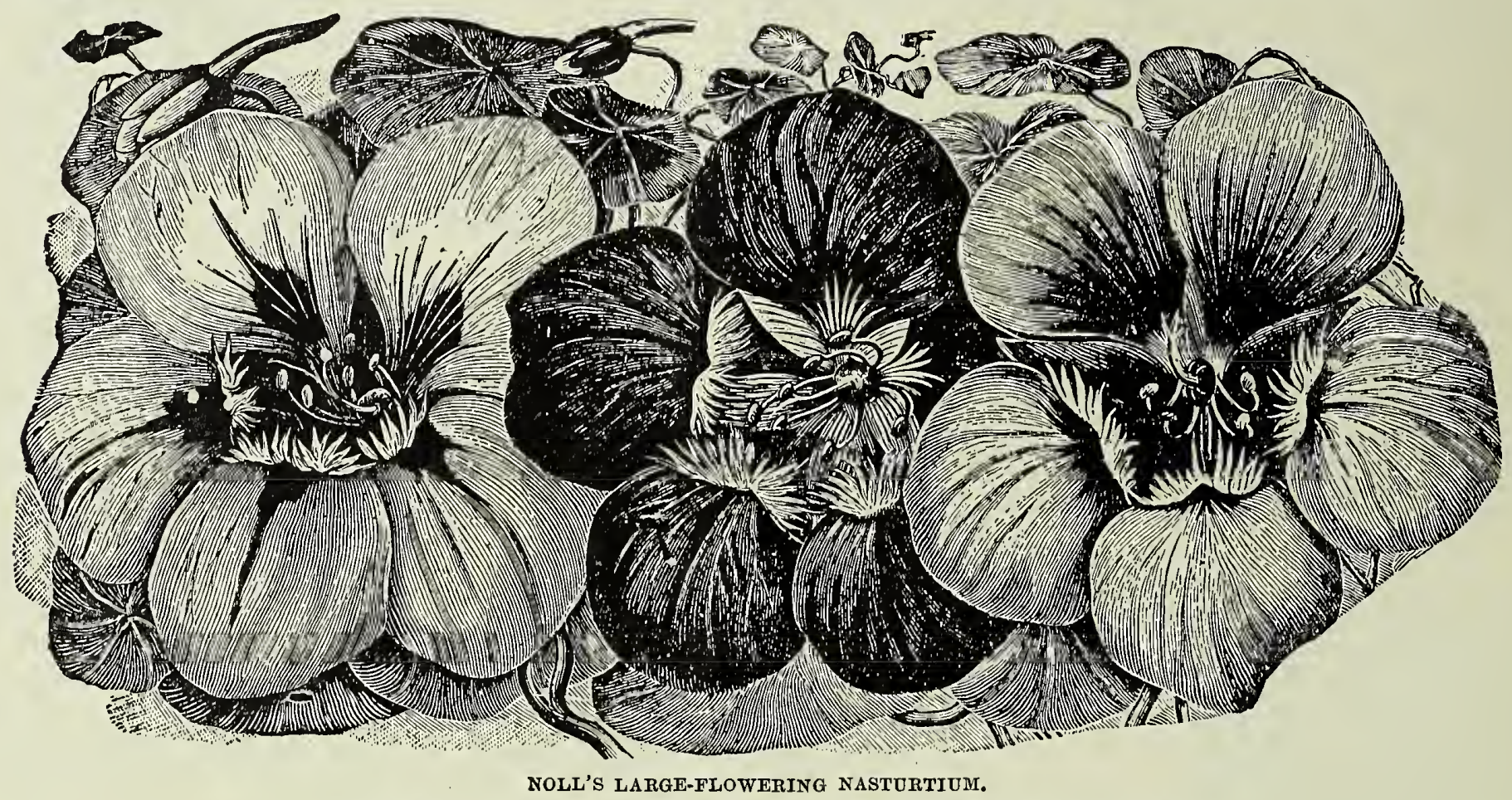

TALL OR CLIMBING NASTURTIUMS

Beautiful and luxuriant annual climbers, for trellises and arbors; of easiest culture, bearing their gorgeous flowers in profusion until killed by frost; six to ten feet.

1500 Atropurpureum. Crimson. Pkt. 5c., oz. 15c.

1501 Coecineum. Scarlet. Pkt. 5c., oz. 15e.

1502 Golden-Leaved. Scarlet, yellow folíage. Pkt. 5c., oz. 15c.

1503 Hemisphaerieum. Orange. Pkt. 5c., oz. 15c.

1504 King Theodore. Crimson, blue foliage. Pkt. 5c., oz. 15c.

1505 Pearl. Creamy white. 1kt. 5c, oz. 15c.

1506 Prinee Henry. Light yellow, marbled scarlet. Pkt. 5c., oz. $15 \mathrm{c}$.

1507 Sehulzi. Scarlet, very lark foliage. Pkt. 5c., oz. 15c.

1509 Vesuvius, Salmon, blue foliage. Pkt, 5c., oz. 15c,

1509 Saturn. Velvety-crimson, very large. Pkt. 10c., oz. 25c.

1510 Jnpiter. Deep golden yellow. Pkt. 10c., oz. 25c.

1511 Noll's Superb Large-Flowered, Mixed. Comprising 21 novelties of a famous English raiser, offered by us exclusively, distingui-hed by vari-colored foliage and flower of great richness and variety of coloring. Pkt, 10c., nz. 25c.

1512 Choiee Mixed. Pkt. 5c., oz. 10c., 1/4 lb. 30c., lb. 75c.

\section{TOM THUMB OR BEDDING NASTURTIUMS}

For showy and constant bloom few garden flowers equal the dwarf nasturtinm, which, hy the way has been great y imprnver during the past few years in color and habit of growth. They are sure to bloom from early summer until killed by frost. No garden can be complete without a fair representation of them; 8 to 12 inches.

1513 Aurora. Rosy salmon, blotched garnet. Pkt. 5c., oz. 15c.

1514 Beauty. Yellow and scarlet. Pkt. 5c., oz. 15e.

1515 Bronze. Coppery bronze. Pkt. 5c., oz. $15 \mathrm{c}$.

1516 Chamaeleon. Crimson and yellow. Pkt. 5c., oz. $15 \mathrm{c}$.

1517 Coeeineum. Light scarlet. Pkt. 5c., oz. 15c.

1518 Cloth of Gold. Scarlet-yellow foliage. Plit. 5c., oz., $15 \mathrm{c}$.

1519 Crystal Palaee Gem. Sulphur, spotted maroon. Pkt. 5e., oz. 15c.

1520 Empress of India. Dark crimson, blue foliage. Pkt. 5c., oz. $15 \mathrm{c}$.

1521 Golden King. Golden maroon blotches. Pkt. 5c., oz., 15c. 1522 Golden Queen. Yellow foliage. Pkt, 5c., oz.15c.

1523 King of 'Tom Thumbs. Dark scarlet, dark leaved. Pkt. $5 \mathrm{c}$, , oz. $15 \mathrm{c}$.

1524 King Theodore. Garnet, blue foliage. Pkt. 5c., oz., 15c.

1525 Lueky Bird. Orange, spotted red. Pkt. $5 \mathrm{c} .$, oz. 15c.

1526 Luteum. Clear yellow. Pkt. 5c., oz. 15c.
1527 Pearl. Creamy white. Pkt. 5c., oz. 15c.

1528 Prince Henry. Light yellow, marbled scarlet. Pkt. 5c., oz. 15c.

1529 Regeliannm. Purnlish violet. Pkt. 5c., oz. 15c.

1530 Rose. Soft rose. Pkt. 5c., oz. 15c.

1531 Ruby King. Ruby red. Pkt. 5c., oz. 15c.

1532 Vesuvius. Salmon, bluish foliage. Plt. 5 c., oz. 15c.

1533 Noll's Dark Foliage Hybrids. Beautiful very dark-bluishleaved class, with large brilliant dark red, rose and crimson flowers; an extra fine class for pot culture. Pkt.10c., oz. $25 \mathrm{c}$.

1534 Noll's Superb Large-Flowered, Mixed. Comprising 17 novelties of a famous English grower, embracing the most brilliant and conspicuous flowered sorts, offered by us exclusively. Pkt. 10c., oz. 25c.

1535 Choiee Mixed. Pkt. 5c., oz. 10c., 1/4 lb. 30c., lb. $75 \mathrm{c}$. 
High Class Seeds

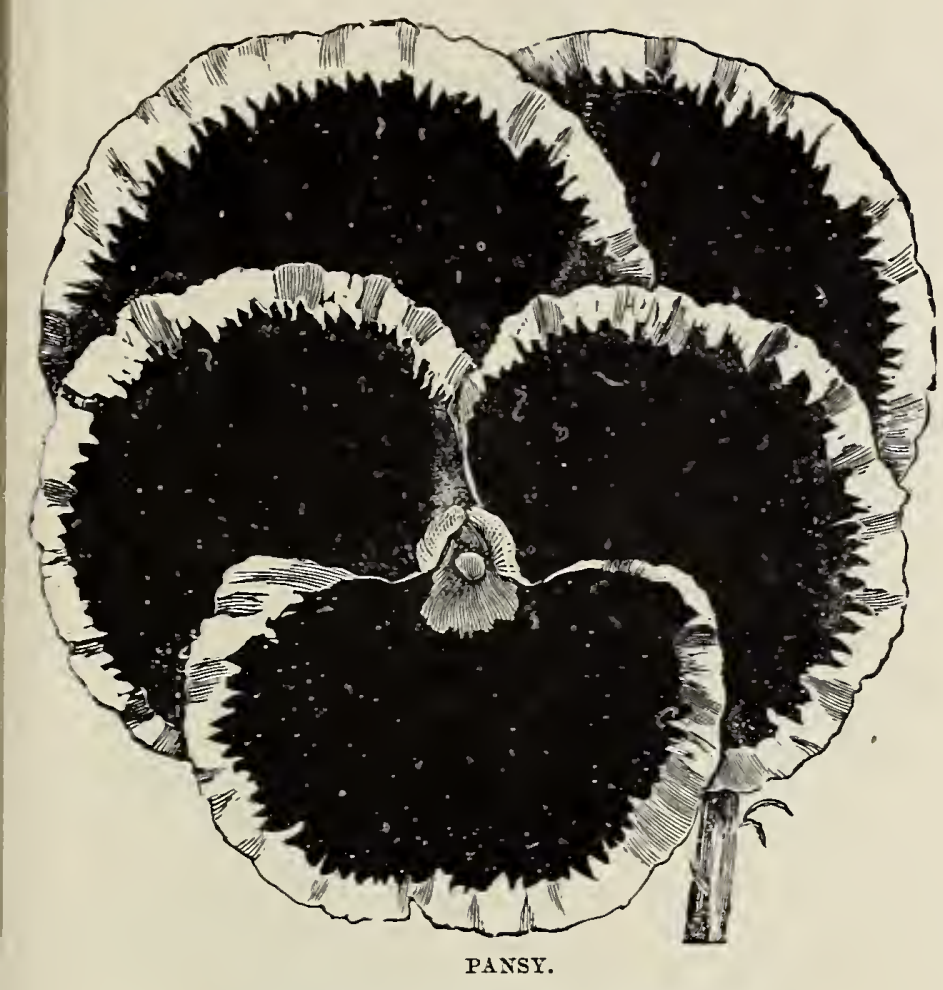

\section{PASSION FLOWER}

Handsome, rapid-growing perennial climber, for greenhouse decoration or sunny positions in the open ground in summer.

1690 P. incarnata ("May Pops"). Blooms the first season from seed. Flowers two or three inches across. Flesh color, with purple rays, followed by yellow, edible fruits. Pkt. 10c., trade pkt. 25c.

1691 P. coerulea grandifiora. Large flowers of violet and blue. Pkt. 10c., trade pkt. 25c.

\section{PENTSTEMON grandiflorus}

Hardy garden perennials, two to three feet high, with large foxgloveIike flowers of various brilliant colors. Will flower the first year from seed if sown early. Pkt. 10c., trade pkt. 25c., oz. \$2.50.

\section{PETUNIA}

The strains we offer are the results of years of careful hybridization and selection. The double and large single sorts are usually selected for window culture, and bloom freely all times of the year. For bedding out in summer they are equally valuable. A bed of petunias is a mass of gay colors from early spring to late fall.

\section{DOUBLE VARIETIES}

Our strains of this important seed are of the highest quality, all seed being saved from pot-grown plants. Customers may rely upon getting the best results obtainable. NotE.-Double petunia grown from seed produces a percentage of double flowers; the balance in single flowers of the same rich shade. The weaker seedlings should be carefully selected, as these always produce double flowers.

1701 Prize Giant. Large-flowering, double, fringed, mixed. Magnificent strain of very large flowers. The very finest varieties and colors will be obtained from this class. Pkt. 25c., 500 seeds $75 \mathrm{c}$., 1,000 seeds $\$ 1.50$.

\section{SINGLE VARIETIES}

1703 Mammoth Fringed, mottled, striped and reined. A new class of remarkable beauty, size and luxuriance, unequaled by any other; the flowers are exquisitely ruffled or fringed, and are of enormous dimensions (four to five inches across); but their great merits lie in the tremendous varieties of colors, markings, veinings, blotchings and stripings, in the most beautiful combinations; the colors are rich and gorgeous and others of lovely delicate shades. This strain represents the acme of perfection in single petunias; 10 in. Pkt. 25c., trade pkt. \$1.00, 1-32 oz. \$1.50.

1704 California Yellow Throat.d. Large flower with yellow throat. Tery fine. Pkt. 25c., trade pkt. $\$ 1.00$.

1707 Dwarf Compacta, striped. Very dwarf, handsome, compact growing sorts, all bright, charming colors, crimson-striped white; very free and constant bloomers; excellent for pots; sure to give satisfaction; 6 to 8 in. Pkt. 10c., trade pkt. 40c., $1 / 4$ oz. $\$ 1.00$.

1711 Fine Mixed. Pkt. 5c., oz. 50c. oz. $25 \mathrm{c}$. Pkt. 10c., oz. $\$ 3.00$.
J. F. NOII \& CO.

115 Mulberry St., Newark, N. J.

\section{NICOTIANA (Tobacco)}

NIGELLA (Love-in-a-Mist, or Devil-in-the-Bush)

Theseold garden fuvorites are very showy in foliage, flowers and seed pods. The pretty flowers are surrounded by a delicate wreath of fine, 1570 Mixed. Double. Dwarf, white and blue; $1 \mathrm{ft}$. Pkt. 5c., trade pkt. 10c.,

\section{OXALIS}

Exceedingly free-flowering little plants with lively foliage, and entirely with bright flowers; annual.

rosea, mixed. Red, white and pink; excellently adapted for pots. PANSY

\section{t blue. Pkt. 10c., oz. \$3.00.}

1601 Giant Dark Blue. Black blue. Pkt. 10c., oz. $\$ 3.00$.

oz. \$6.0. Lerd Beaconsfield. Lavender, heliotrope and purple.

Giant Freya. Silver-edged. Pkt. 10c., oz. $\$ 3.00$

1606 Giant Golden Queen. Pure yellow. Pkt. 10c., oz. $\$ 3.00$

Giant King of the Blacks. Lustrous jet black. Pkt. 10c., oz. $\$ 3.00$.

608 Giant Peacock. Garnet, eream and blue. Pkt. 15c., oz. \$6.00.

1609 Giant Purple King. Purple, extra. Pkt. 15c., oz. \$5.00.

1611 Giant Snowflake. Pure snow-white. Pkt. 10c., oz. $\$ 3.00$

1612 Giant Striped. White, blue and violet. Pkt. 10c., Oz. $\$ 3.00$.

1613 Giant Trimardeau. Mrixed colors. Pkt. 10c., oz. \$2.00. markings. They embrace all the solid colors, striped and colors, delicate shaded flowers, face varieties, and flowers with distinct eves. We have taken great care in selecting this growers of this valuable flower. Pkt. 25c., 1/8 cz. \$1.25, oz. S 00.

1616 Largest-Flowering. finest French, Mixed. Pkt. 10c., trade pkt. 25 c., oz. $\$ 1.00$

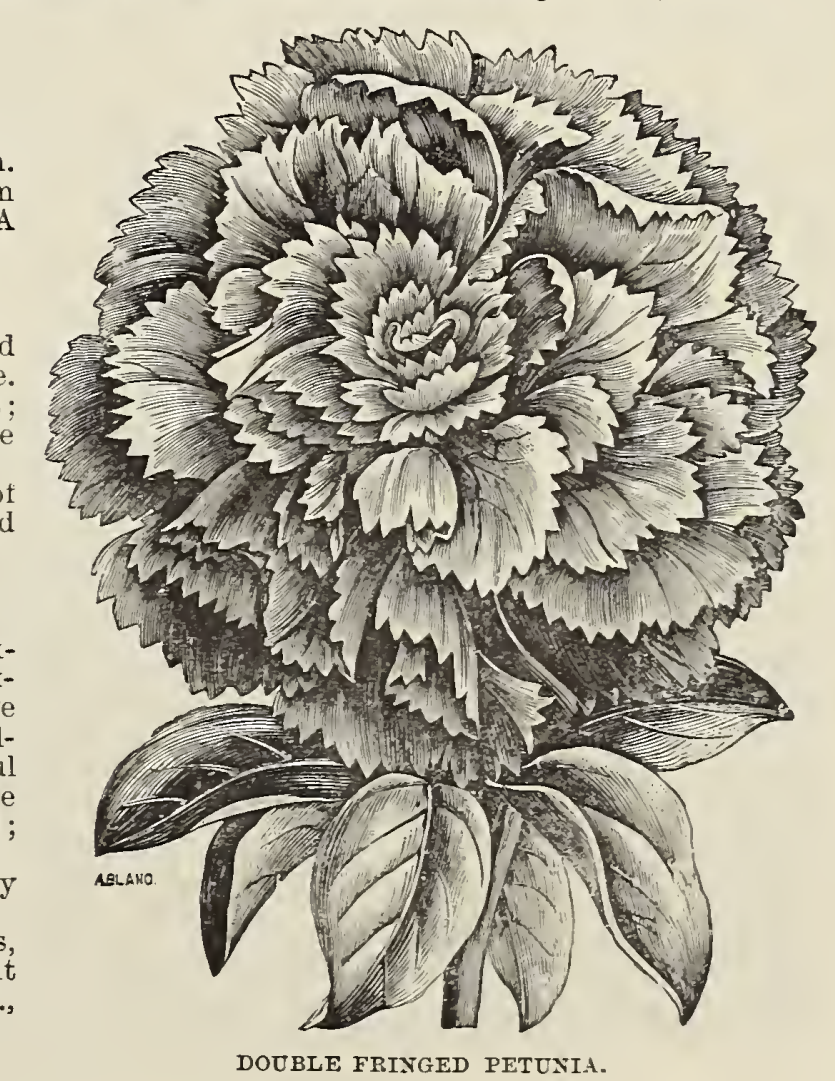




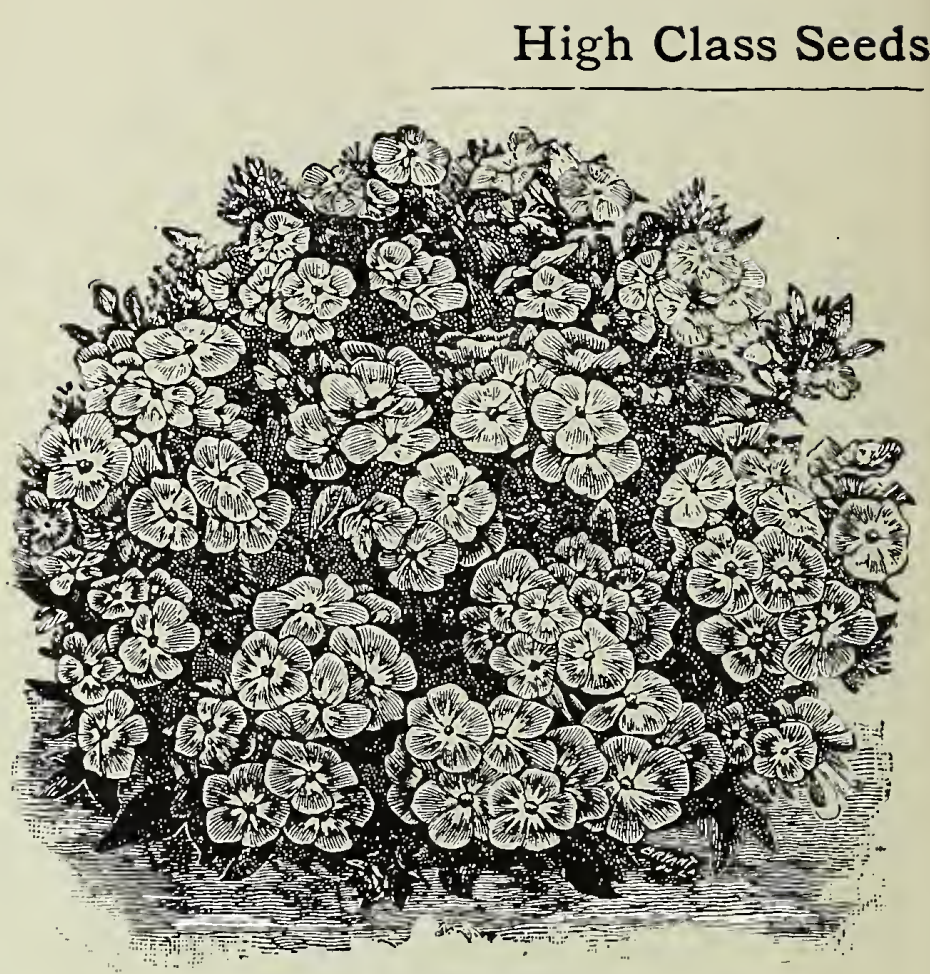

PHLOX DRUMMONDI.

Little may be said in favor of this grand annual. Everybody knows and cultivates it for its brilliant colors. It is truly called the "Flame-Flower." A bed in blooin dazzles the eye with its brilliancy, and the different colors sown side by side produce a beautiful effect; annual; $1 \mathrm{ft}$.

1730 Alba. Pure white, beautiful large flowers. Pkt. 5c., trade pkt. 25c., oz. $\$ 1.00$.

1731 Kermesina Splendens. Vivid erimson. Pkt. 5e., trade pkt. 25c., oz. $\$ 1.50$.

1732 Stellata Alba. White with red eye. Pkt. 5c., trade pkt. 25c., oz. \$1.25. 1733 Stellata Atropurpurea. Purple with white eye. Pkt. 5c., trade pkt. 25c., Oz. $\$ 1.25$.

1734 Stellata Rosea. Pink with white eye. Pkt. 5c., trade pkt.25c., oz. $\$ 1.25$.

1735 Stellata Splendens. Crimson with white eye. Pkt. 5c., trade pkt. $25 \mathrm{c} ., \mathrm{Oz} . \$ 1.50$.

1736 Fine Mixed. Pkt, 5c., trade pkt. 25c., oz. $\$ 1.00$.

\section{PHLOX DRUMMONDI NANA}

(New Improved Dwarf Compact Varieties)

1741 Oculata. New brilliant varieties, very handsomely oculated, fine. Pkt. 10c., trade pkt. 40c., oz. \$2.00.

1742 Snowball. Beautifully white. Pkt. 10c., trade pkt. 40c., oz. $\$ 2.00$.

1743 Fireball. Brilliant searlet. Pkt. 10c., trade pkt. 40c., oz. $\$ 2.00$.

1745 Noll's Superb Mixed. Comprising only the most brilliant, showy and salable colors, embracing twenty-two of the finest varieties. Pkt. 10c., trade pkt. 50c., oz. $\$ 3.00$.

1750 Star of Quedlinburg. Star phlox, choice mixed. Improved strain comprising only large flowers. Pkt. 10c., trade pkt. 25c., oz. \$1.00

\section{PHLOX DECUSSATA (Hardy Perennial Phlox)}

1761 New Dwarf Large-Flowering Hybrids. Mixed. From the choicest sorts. 11/2 ft. Pkt. 10c., trade pkt. 35c., oz. \$2.00

\section{POPPIES}

\section{DOUBLE ANNUAL (Double Carnation-Flowered)}

A magnificent class of hardy annuals, 2 to $2 \frac{1}{2}$ feet high ; large globular flowers of ten a foot in circumference, of the greatest variety of colors; the petals are finely slashed and fringed. Like all annual poppies they should be sown where they are to be grown.

1778 Mixed Carnation Flowered. Many colors. Pkt. 5c., oz. 25c.

\section{SINGLE ANNUAL}

1770 Armenian Tulip Poppy. A new species, 12 to 14 inches high, each plant producing 50 to 60 vivid scarlet flowers. The two outer petals form a saucer surrounding two erect petals, giving a very unique and handsome appearance of scarlet tulips. Pkt. 5c., oz. 50c. 1771 Shirley. The absence of black blood gives them their wonderfully light, bright, tissue-paper-like appearance. The colors range from purest white through pinks of all shades to glowing scarlet, but a scarlet without black. Mixed Colors. Pkt. 5c., oz., 50c.

1772 Dannebrog. Brilliant scarlet blotehed with silvery white. Pkt. 5c., oz. 25c.

1773 Mephisto. Scarlet with black spots. Pkt. 5c., oz. 25c.

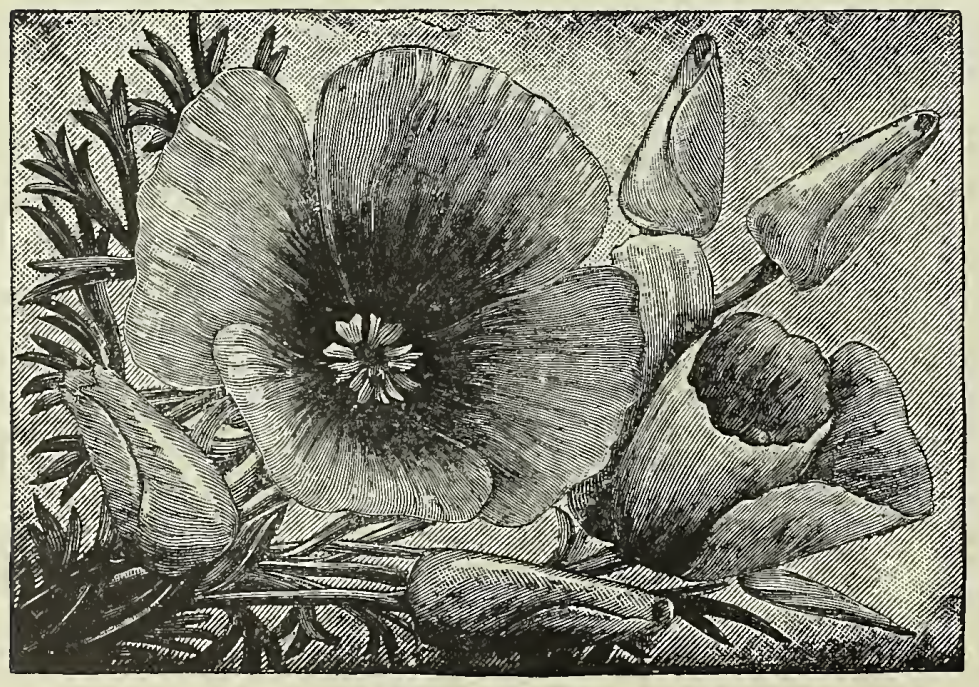

CALIFORIIA POPPY.
1774 Miss Sherwood. Satiny white, shading to chamois rose. Pkt. 5c., Oz. 50c.

1775 The Bride. Single white fringed. Pkt. 5c., oz. 25c.

1776 Umbrosum. Glowing vermilion. Pkt. 5c., oz. 25c.

1777 Single Annual Mixed. Pkt. 5c., oz. 25c.

\section{DOUBLE PEONY-FLOWERED POPPIES}

A magnificent class of annual poppies; immense double broad-petaled flowers, in form resembling pæonies. Height about 2 feet.

1779 Double Peony-Flowered Poppies. Mixed. Pkt. 5c., oz. 25c. 1780 Ranunculus-Flowered. Double Mixed. Pkt. 5c., oz. $25 \mathrm{c}$.

1781 Cardinal. Double bright rose. Pkt. 5c., oz. 25c.

1782 "“ "s scarlet. Pkt.5c., oz. 25c.

1783 " " white. Pkt. 5c., oz. 50c.

1784 Double Annual. Mixed. Pkt. 5c., oz. 25c.

\section{HARDY PERENNIAL POPPIES \\ (New Giant Oriental)}

Among hardy perennials these hold an unrivaled position for gorgeous effectiveness in gardens and hardy borders; height, two to three feet; flowers immense, often six inches aıross.

1785 Fiery Scarlet. Pkt. 10c.

1786 New Oriental Hybrids. Mixed colors. Pkt. 10c. 


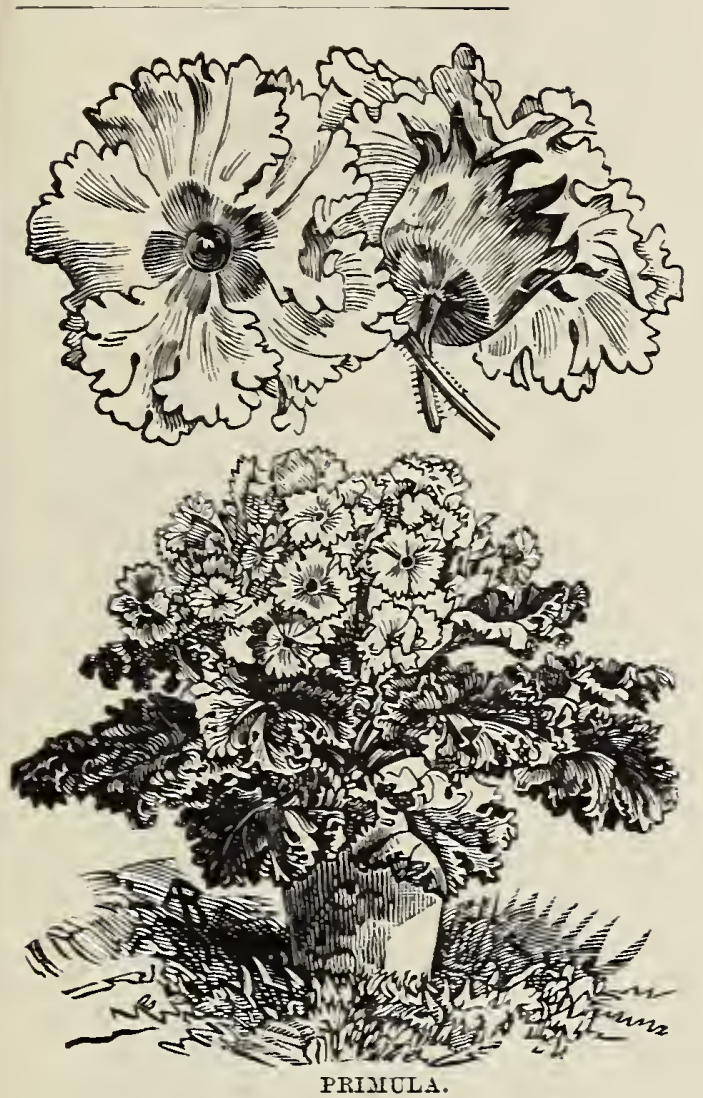

\section{ICELAND POPPIES (Papaver Nudicaulc)}

Although hardy perennials, these Poppies bloom the flrst season from spring-sown seed. The fragrant, elegant, crushed, satin-like flowers are produced in never-ceasing succession from the beginning of June to October. The flowers last quite a week if cut as soon as open.

1787 Single Mixed Iceland. Pkt. 10c., oz. $\$ 1.00$.

1788 Double Mixed Iceland. Pkt. 10c., oz. $\$ 1.50$

\section{PRIMULA \\ CHINESE PRIMROSES (Primula Chinensis)}

1800 Giant alba magnifica. Large, beautiful pure white, with citron eye; compact; light green foliage. Pkt. 50c., half trade pkt. 60c., trade pkt. $\$ 1.00$.

1801 Giant Coccinea. New, handsome brilliant red; abundant bloomer. Pkt. 50c., half trade pkt. $60 \mathrm{c}$., trade pkt. $\$ 1.00$.

1802 Giant Blue. Pkt. $5^{\mathrm{n}} \mathrm{c}$., half trade pkt. $60 \mathrm{c}$., trade pkt. $\$ 1.00$.

1807 Giant Exhibition Prize Strain. IFixed. Remarkable for large-size, varied and brilliant-colored flowers in beautiful variety; the finest and best strain extant. Pkt $50 \mathrm{c}$. , half trade pkt. 60c., trade pkt. $\$ 1.00$.

1808 Fine Mixed. Good strain. Pkt. 25̃c, trade pkt 50c.

\section{PRIMULA (Various Sorts)}

With a slight protection they will stand the winter but do better if protected by a cold frame.

1810 P. obconica grandiflora. Scarlet. Pkt. 15c., trade pkt. 50c.

1811 P. obconica grandiflora fimbriata. White. Pkt. 15c., trade pkt. 50c.

1812 P. obconica grandiflora fimbriata. Pink. Pkt. 15c., trade pkt. 50c.

1813 P. obconica grandiflora fimbriata. Hybrid; fine mixed; blooms freely nine months in the year; fringed; 6 inch. Pkt. $15 \mathrm{c}$., trade pkt. 50c.

1820 P. reris. Mixed. English cowslip: extra quality. Pkt. 10c., trade pkt. 25c.

1821 P. Forbesii (Baby Primrose). Pkt. 15c., trade pkt. 50c.

\section{PYRETHRUM}

1930 P. aureum (Golden Feather). True; 1/2 ft. Pkt. 5c., trade pkt. 15c., oz. 50c.

PORTULACA

They do the best in hot, sunny situations, and no matter how dry the weather, they will grow and flourish, even on very poor soil For borders of beds they are very effective with their striking colors.

1790 P. grandiflora. Single, Mixed. Extra fine. Pkt. 5c., trade pkt. 15c., oz. 50c.

1791 P. grandifiora. Double, Mixed. Extra choice colors. Pkt. 10c, trade pkt. 35̃c., oz. \$2.50.

\section{RICINUS (Castor Oil Plant)}

Large, luxuriant, rapid-growing foliage annuals, with palm-like leaves; much used for sub-tropical effects on the lawn, or for centers of beds of foliage plants.

1950 R. cambodgensis. Leaves bronzy maroon, with red veins, stems black. Pkt. 5c., oz. 25.c.

1951 R. borbonensis. 15 feet. Immense foliage. Pkt. 5 c., oz. $20 \mathrm{c}$.

1952 F. Gibsonii. Six feet. Dark purplish red foliage and stems. Pkt. 5c., oz. 20c.

1953 12. zanzibarensis. Their gigantic leaves, two to two and one-half feet across, and the great size of the plants surpass any other Ricinus. We offer our varieties in mixture; one will produce light green leaves, with whitish ribs; another, coppery brown leaves, changing to dark green with red ribs-stems brown; another, brownish purple leaves, changing to dark green with reddish stems; another, with bronze leaves with reddish ribs and glaucous brown stems. Price, the four varieties just described, in mixture, Pkt. 5c., oz. 20c.

\section{SALPIGLOSSIS (Velvet Flower)}

The funnel-shaped flowers are large in size and singularly and most vividly marked and delicately penciled, spotted and striped on ground colors of deep blue, rose, dark violet, light yellow, reddish bronze, etc.; 18 inches. $1970 \mathrm{~S}$. rariabilis grandiflora. Mixed. Pkt. 5e., trade pkt. 25̌c.,oz. $\$ 1.25$

\section{SALVIA}

Blooms till frost; half-hardy perennial; blooming the first jear from seed.

1980 S. splendens grandiflora (Scarlet Sage). Beautiful bright scarlet; $3 \mathrm{ft}$. Pkt. 5c., trade pkt. 30c., oz. $\$ 1.50$.

1981 Clara Bedman ("Bonfire"). Its erect spikes of flowers of brilliant scarlet stand clear above the dark-green foliage and completely cover the plant. It attracts immediate attention in the garden, and is one of the most effective and gorgeous of plants in cultivation; 18 in. Pkt. 10c., trade pkt. 50c. oz. $\$ 2.50$.

1982 Patens (Blue Salvia). A handsome blue variety. Pkt. $10 \mathrm{c}$., trade pkt. 50c.

1983 Silverspot. A variety bearing red flowers; leaves spotted white. Pkt. $10 \mathrm{c}$. , trade pkt. $50 \mathrm{c}$.

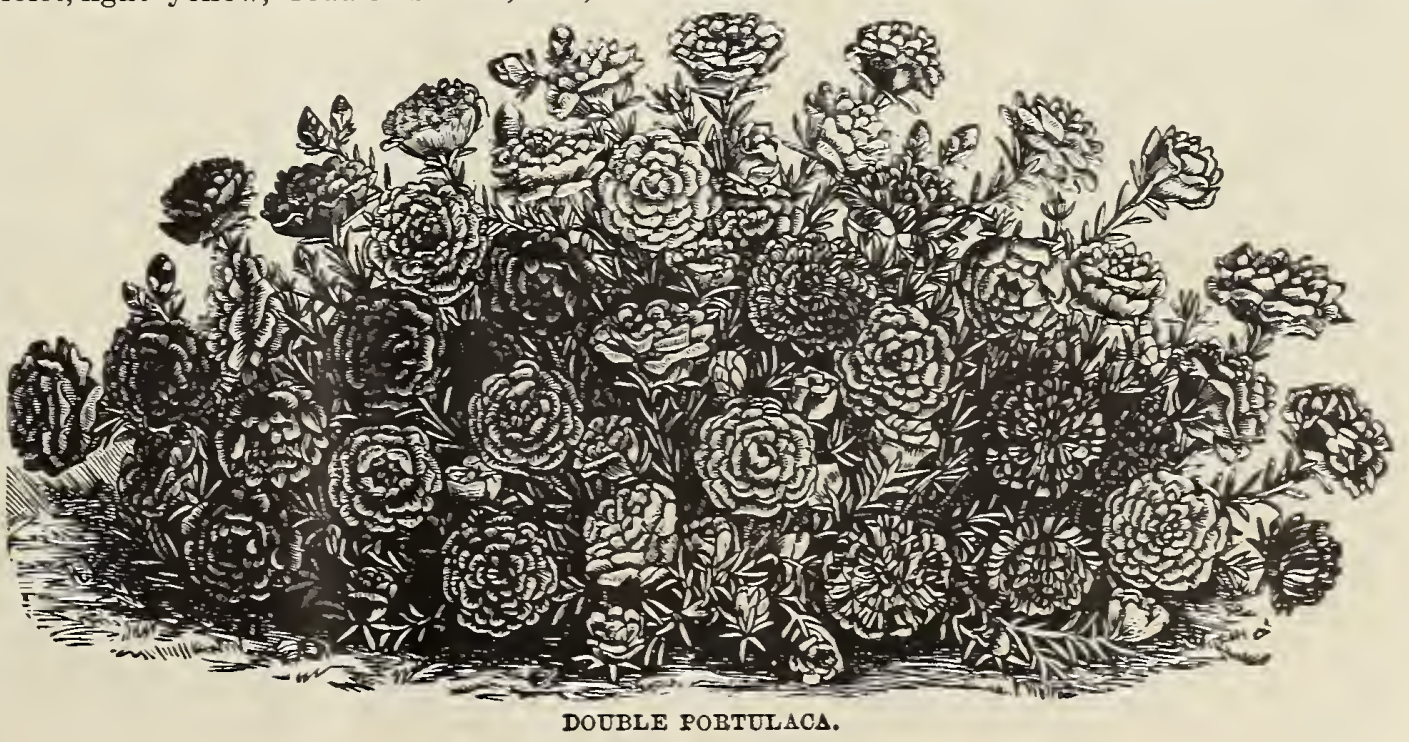


One of our handsomest summer border plants, producing in great profusion very double flowers in a variety of shades and colors; a splendid flower for table bouquets, etc.; hardy annual.

2000 Large-Flowering Double, Mixed. Comprising all the flne sorts, embracing ten shades; $3 \mathrm{ft}$. Pkt. 5c., trade pkt. $15 \mathrm{c}$., oz. $35 \mathrm{c}$.

SCHIZANTHUS (Butterfly Flower, Christmas Orchid Flower)

A splendid annual; fine for greenhouse decoration and the flower garden; of easy culture. 2016 Papilionaceous Hybrids; Mixed. Pkt. 5c., trade pkt. 15c.

\section{SILENE}

2020 Pendula. An effective garden annual, forming compact, round bushes, 12 inches high, which, during the summer, are covered densely with flowers of white, pink or red. For low beds or edgings it is very pretty. Mixed colors. Pkt. 5c., trade pkt. 10c., oz. 30c.

2021 Schafta. Pink, hardy perennial. Pkt. 10c., trade pkt. 25c., oz. 75c.

\section{SENSITIVE PLANT (Mimosa)}

Curious and interesting plants, with pinkish white flowers; the leaves close and droop when touched or shaken; requires a mixed soil.

2030 Mimosa pudica. 11/2 ft. Pkt. 5c., trade pkt. 10c., oz. 50c

\section{SMILAX}

2050 Myrsiphyllum. New crop; 6 ft. Pkt. 10c., trade pkt. 15c., oz. 40c., lb. $\$ 3.50$.

SUNFLOWER (Helianthus)

Remarkable for the stately growth, size and brilliancy of their flowers, making a very good effect among shrubbery and for screens; hardy annuals.

2090 Globe of Grold. A new double dwarf annual Sunflower, forming a well branched plant, not exceeding forty inches in height. Each of the numerous branches carries on its summit a large, densely double globe-shaped flower of deep rich, golden yellow color. Pkt. 10c., trade pkt. 20c., oz. 50c.

2091 Mammoth Double. Enormous flowers; very double. Pkt. 5c., oz. $25 \mathrm{c}$.

2092 Mammoth Single Russian. Pkt. 5c., oz. 10c.
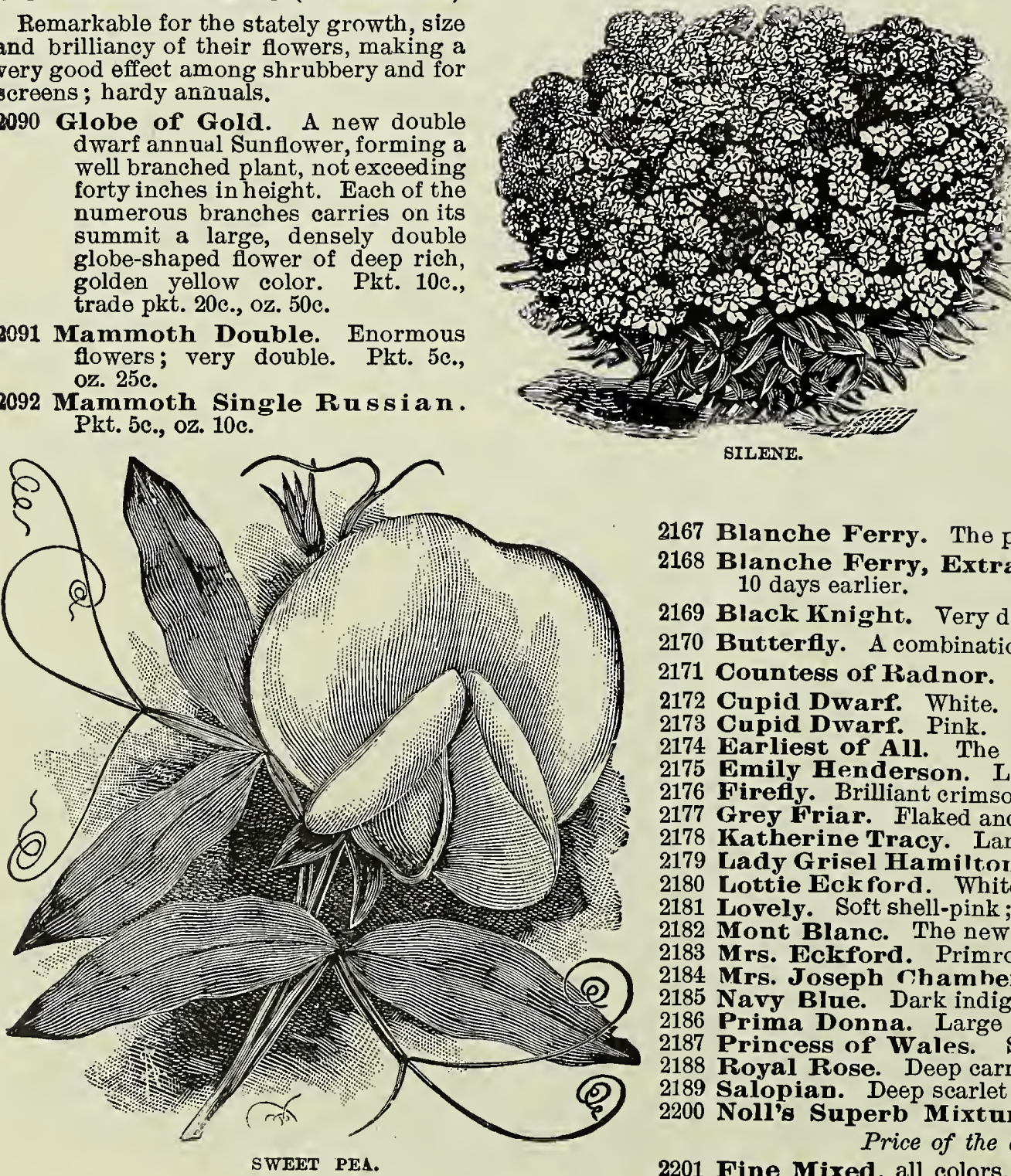

2167 Blanche Ferry. The popular pink and white; very profuse.

2168 Blanche Ferry, Extra Early. Color same as preceding, but flowers 10 days earlier.

2169 Black Knight. Very dark maroon, almost black.

2170 Butterfly. A combination of shades of violet and lavender.

2171 Countess of Radnor. A beautiful shade of lavender.

2172 Cupid Dwarf. White.

2173 Cupid Dwarf. Pink.

2174 Earliest of All. The earliest strain of Blanche Ferry ; fine for forcing.

2175 Emily Henderson. Large early pure white; strong grower.

2176 Firefiy. Brilliant crimson-scarlet; profuse bloomer.

2177 Grey Friar. Flaked and speckled blue and mauve on white.

2178 Katherine Tracy. Large soft pink.

2179 Lady Grisel Hamilton. Beautiful silvery lavender.

2180 Lottie Eck ford. White, shaded and edged deep lavender.

2181 Lovely. Soft shell-pink; large and extra fine.

2182 Mont Blanc. The new extra early pure white; fine for forcing.

2183 Mrs. Eckford. Primrose-yellow; large size and fine form.

2184 Mrs. Joseph Ghamberlain. Striped bright rose on white; very large

2185 Navy Blue. Dark indigo blue; the best blue.

2186 Prima Donna. Large pure pink; a fine shade and grand flower.

2187 Princess of Wales. Striped blue and purple on white.

2188 Royal Rose. Deep carmine rose, wings lighter; very large.

2189 Salopian. Deep scarlet or cardinal, very large, the best red.

2200 Noll's Superb Mixture of all large-flowering varieties. Price of the above, oz. 10c., $1 / 4 \mathrm{lb}, 20 \mathrm{c}$., lb. 60c.

2201 Fine Mixed, all colors, oz. 5c., 1/4 lb. 15c., lb. $40 \mathrm{c}$. 


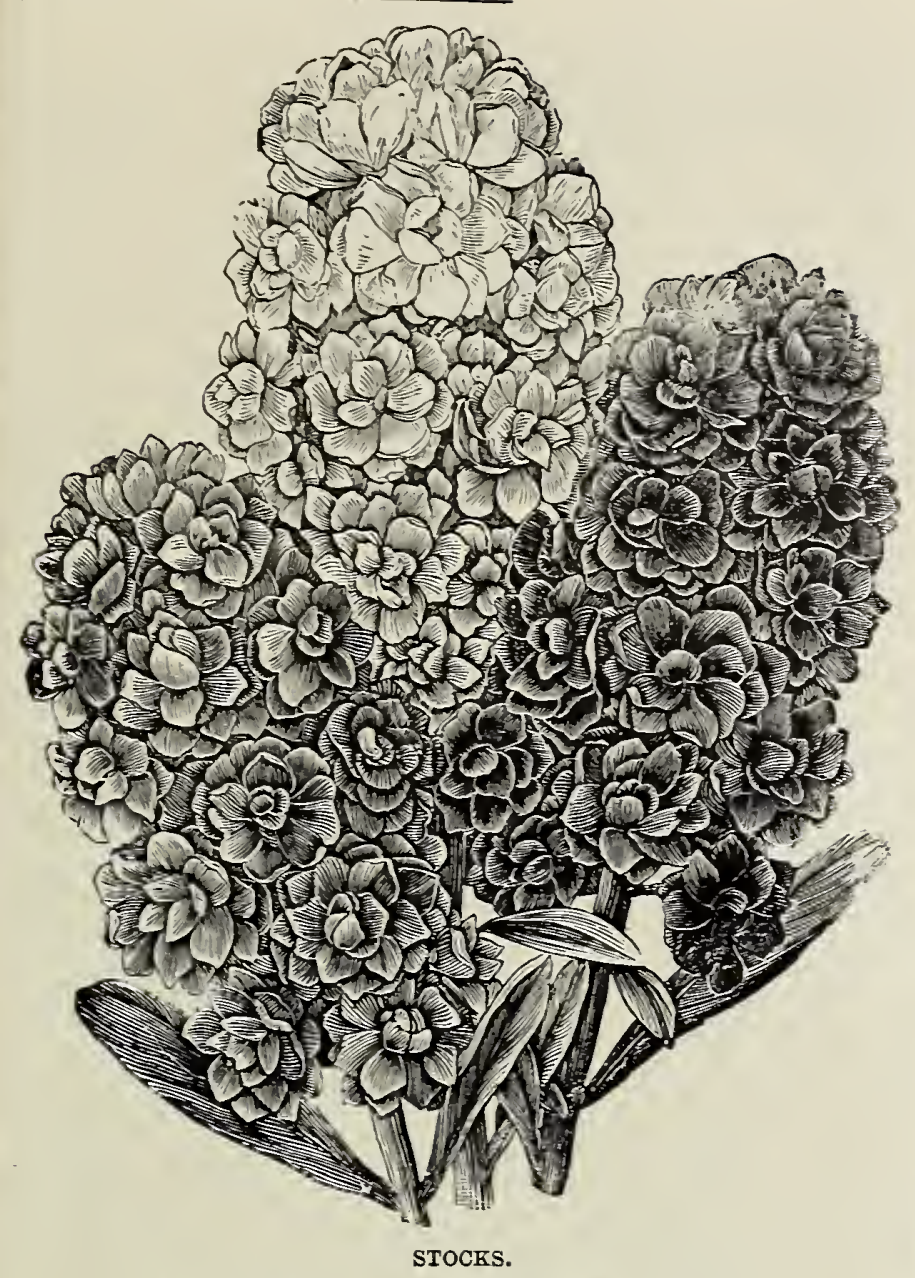

\section{TECOMA VELUTINA}

2135 A beautiful shrub, bearing large spikes of golden yellow flowers, resembling allamandas. It blossoms from seed when only 12 in. high, and is a continuous and perpetual bloomer. An excellent plant for the greenhouse or conservatory. Pkt. 10c., trade pkt. $25 \mathrm{c}$. $\mathrm{Oz}$. $\$ 3.00$.

\section{THUNBERGIA (Black Eyed Susan)}

Beautiful rapid-growing climbers; the flowers are very pretty, and ars borne profusely during the season; flne for vases, rustic-work or greenhouse culture.

2136 Thite, Black eye. Pkt. 5c., trade pkt. 20c., oz. 75 c. 2137 Orange, Black eye. Pkt. 5 c., trade pkt. 20c., oz. $75 \mathrm{c}$. 2138 Mixed. Pkt. 5c., trade pkt. 20c., oz. 60c.

\section{TORENIA}

A very fine annual; a beautiful plant for vases, hanging-basketș or edgings, berng covered the entire season with bloom; excellent greenhouse plant.

2140 T. Fournieri grandiflora. Beautiful; rery large porcelain blue and rich violet; throat bright sellow; very free flower. Pkt. 10c., trade pkt. 35c.

\section{VINCA (Madagascar Periwinkle)}

Ornamental free-blooming plants, flower from seed, if sown early, the first season, continuing until frost; $2 \mathrm{ft}$. Home-grown seed sure to germinate.

2150 V. rosea (Rose). Crìmson eye. Pkt. 10c., trade pkt. 20c., oz. $75 \mathrm{c}$.

2151 V. rosea alba. White, crimson eye. Pkt. 10c., trade pkt. 20c., oz. $75 \mathrm{c}$.

2152 V. rosea alba pura. Pure white. Pkt. 10c., trade pkt.20c., oz. $75 \mathrm{c}$.

2153 V. rosea, Mixed. Tell assorted. Pkt. 10c., trade pkt. 20c., oz. 70 c.

\section{VIOLET (Viola Odorata)}

Well-known, fragrant, early spring-blooming, hardy perennials; thriring best in a shady situation, in a rich, deep soil.

2155 V. alba. Pure white, sweet-scented. Pkt. 10c., trade pkt. 25c.

2156 V. Empress Augusta. Dark blue; sweet-scented. Pkt. 10c., trade pkt. 50c.
115 Mulberry St., Newark, N. J.

\section{SWAN RIVER DAISY (Brachycome)}

pkt. $15 \mathrm{c}$

\section{SWEET WILLIAM}

This very old and popular flower has been greatly improved the last few years. thice the colors bright and For, and also deliciously sweet-scented; for clumps or borders. No plant can

Dkt. 10c trade pkt. $20 \mathrm{c}$, oz. $60 \mathrm{c}$

\section{SWEET SULTAN}

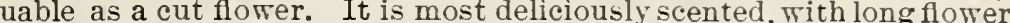
talks, and when cut will last in water two weeks. Beautiful shades of SWEET ROCKET (Hesperis) two to three feet high, and bears spikes of showy white, lilac and pure fragrant flowers. Mixed colors. Pkt. 5c., trade pkt. 10c., oz. 30c.

\section{STOCKS}

\section{Dwarf Large-Flowering Double Ten Weeks}

These popular flowers are easily grown, and are so highly fragrant and of such the so many good qualities, that they deserve a place in

10c. 2123 Blood Red............ Pkt. 10c. ......... " 10c. 2125 Bright Rose......... " $10 \mathrm{c}$. Trade packet of above 50c. each, oz. $\$ 3.00$.

126 Noll's Superb Mixed. Pkt. 10c., trade pkt. 50c., oz. $\$ 3.00$.

\section{DWARF FORCING TEN WEEKS STOCK}

nowflake. The earliest white; fine for forcing. Pkt.10c., trade pkt.50c.

\section{STOCK}

\section{WEEKS}

2130 Princess Alice. White, large spikes. Pkt.10c., trade pkt. 50c.

Deep Red. Pkt. 10c., trade pkt. 50c. right Pink. Pkt. 10c., trade pkt. $50 \mathrm{c}$.

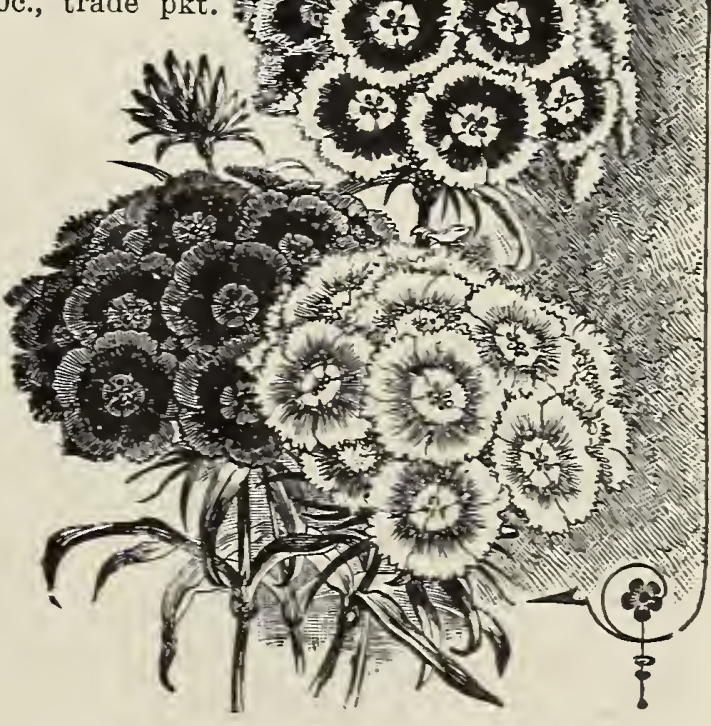

SWヒET FILLIAM. 


\section{VIRGINIAN STOCK}

2290 Mixed. Charming dwarf annuals, with bright-colored red, yellow, crimson and white flowers, making the garden gay in early summer; $1 / 2$ ft. Pkt. 5c., trade pkt. 10c., oz. 30c.

\section{WALLFLOWER}

Wallflowers are the most deliciously fragrant of all garden flowers.

2292 Single Large-Flowering. Mixed. Extra quality; six of the most brilliant colors. Pkt. 5c., trade pkt. 15c., oz. 50c.

2293 Double Large-Flowering. Superb Mixed. Flnest double dwarf branching, comprising rich yellow, bronze, brown, violet and white. Pkt. 10c., trade pkt. 50c.

\section{VERBENA}

\section{American Grown. Extra Quality.}

Verbenas in quantity are more easily obtained from seed than from cuttings, and the plants are more healthy and vigorous in growth, while they are also fragrant, particularly the white and light colored varieties. Our customers may rely upon our strain of Giant-Flowering Verbenas for producing the largest flowers obtainable in their respective colors. 2280 Giant White. Very large flowers; numerous pure white trusses. Pkt. 10c., trade pkt. 40c.

2281 Giant Pink. Beautiful shade. Pkt. 10c., trade pkt. 40c.

2282 Giant Scarlet. Very brilliant; excellent for bedding purposes. Pkt. 10c., trade pkt. $40 \mathrm{c}$.

2283 Giant Crimson. White eye. Beautiful rich shade. Pkt. 10c., trade pkt. 40c.

2384 Giant Oculata. A fine very large-flowered, highly improved type of richly colored purple and handsomely oculated sorts. Pkt. 10c., trade pkt. $40 \mathrm{c}$.

2285 Giant Mixed. A carefully selected and greatly improved strain of new sorts, unequaled by any other for brilliant anu choice varieties.

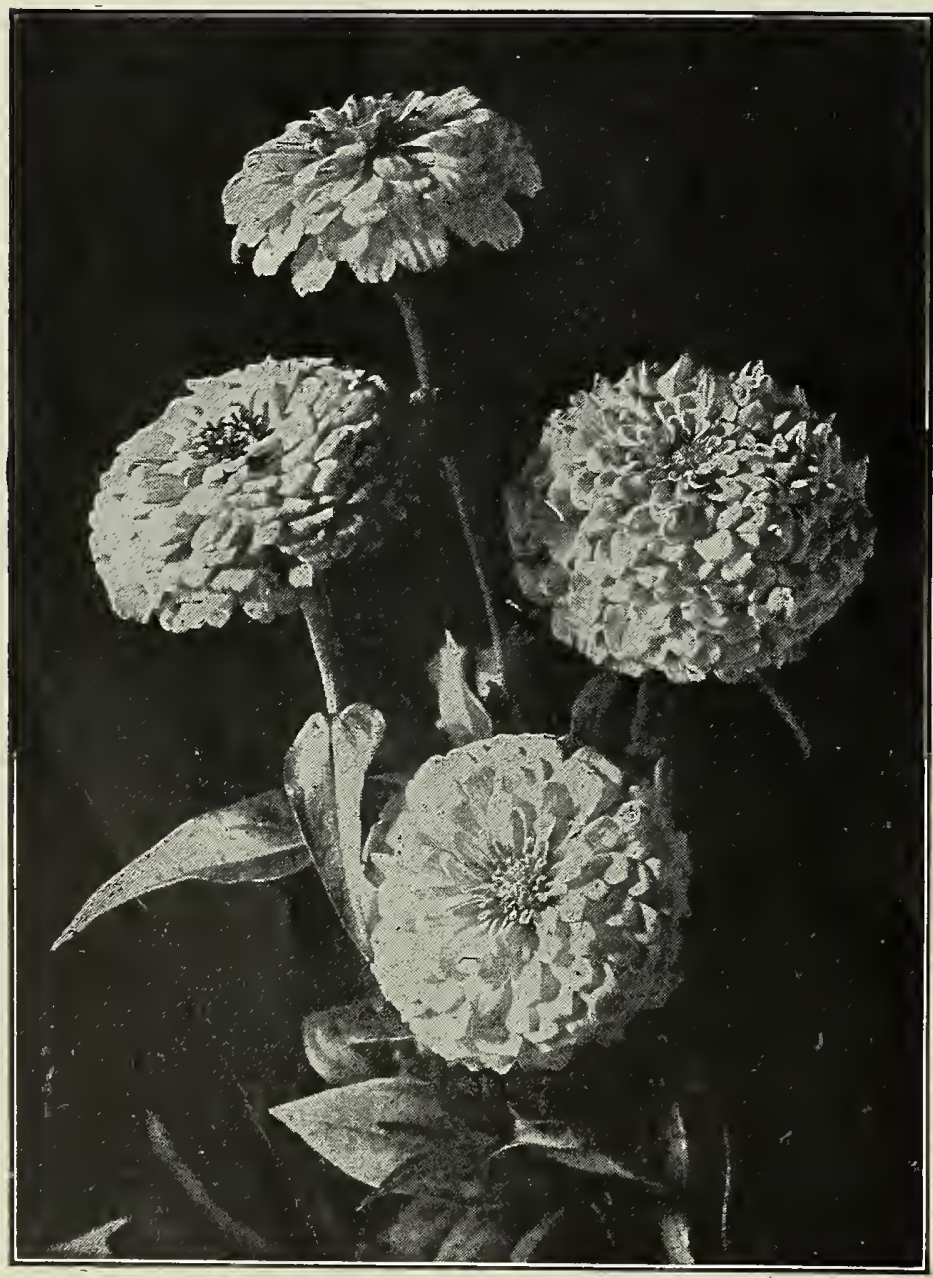

NOLL'S MAMMOTH-FLOWERING ZINNIA

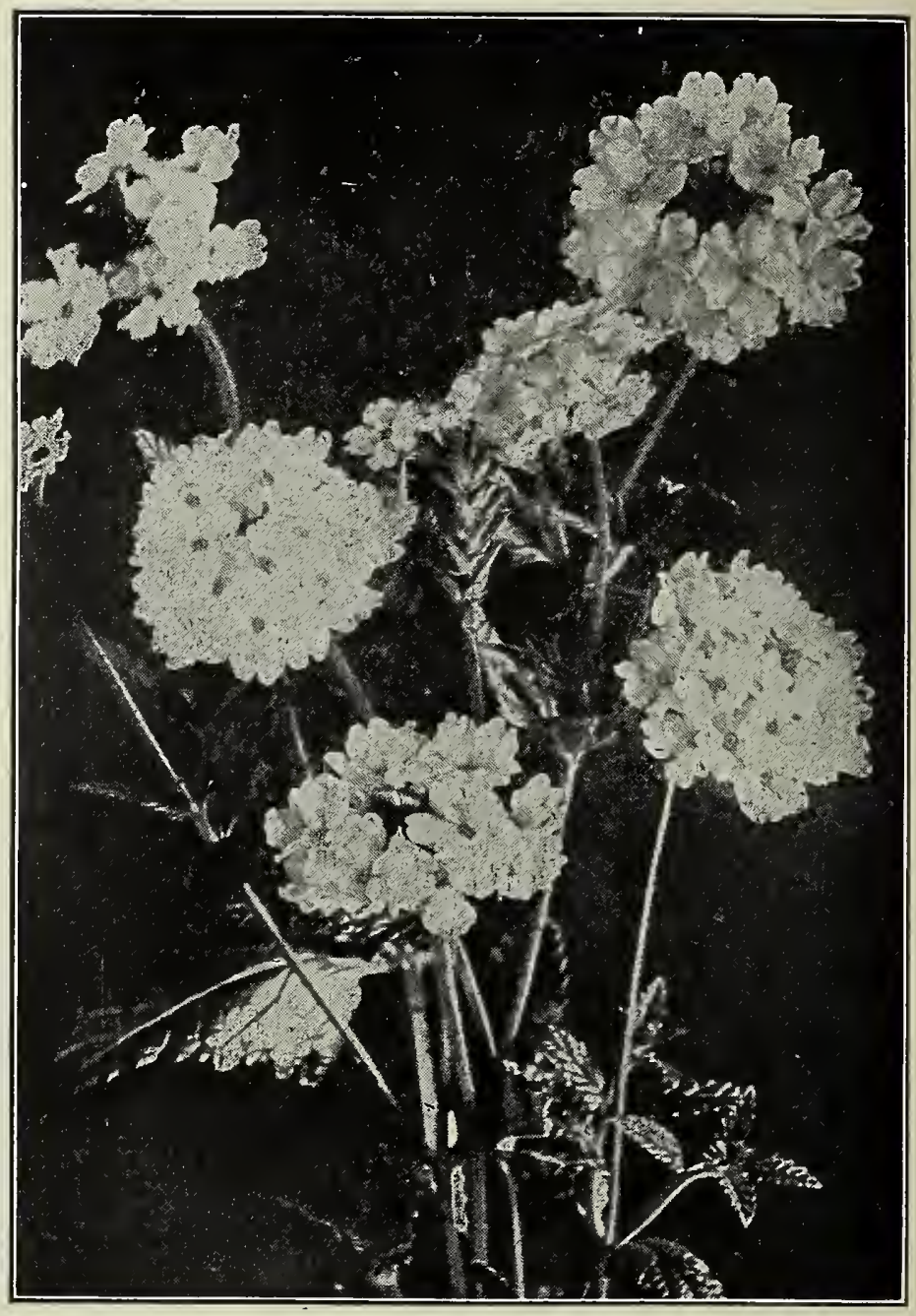

VERBENA Composed of the best and show iest sorts only. Will give extra satisfa ction. Pkt. 10c. trade pkt. 50c., oz. $\$ 3.00$.

2286 French Striped. Saved from a rich collection of Carnation-striped flowers. Pkt. 10c., trade pkt. 30c.

2288 Choice Mixed. Pkt. 5., trade pkt. 20c., oz. $\$ 1.00$.

2290 Lemon Verbena. Grown for the odor of the foliage, which is lemon-scented. Pkt. 10c., trade pkt. 25c.

\section{YUCCA (Adam's Needle)}

2360 Y. filamentosa. A very attractive plant for lawns, bearing a large cluster of snowy-white, tulip-like flowers, in July, hardy perennial. Pkt. 10c., trade pkt. 25c.

\section{ZINNIAS (Youth and Old Age)}

2370 Mammoth-Flowering. Mixed. (Zinnia Grandiflora Robusta Plenissima fl. pl.) The plants form handsome bushes three teet in height and the mammoth perfectly-formed double flowers measure 5 to 6 inches across, comprising be iutiful shades of scarlet, gold, salmon, rose, crimson, orange, gold striped, etc. Pkt. 10c., trade pkt. 25c., oz. $\$ 1.00$

2371 Zebra, or Carnation Striped. A very pretty strain of striped flowers. As the colors vary on each plant, they present a curious as well as beautiful appearance. Pkt. 5c,, trade pkt. 15c., oz. 60c.

2372 Tall Double. Mixed. Pkt. 5c., trade pkt. 10c., oz. 40c.

2373 Dwarf Double. Mixed. Pkt. 5c., trade pkt. 10c., oz. 50c.

\section{AND LAST BUT NOT LEAST, TRY A WILD-FLOWERGARDEN}

2500 A mixture of easy-growing, hardy flowers producing a constant and varied bloom the whole season; for sowing in shrubbery, under trees, and in beds of which no care will be bestowed or even for sowing in exposed situations, where wilderness is preferred to order and precision. Pkt. 5c., oz. 15c., $1 / 4$ lb. 50 e. 


\section{SUMMER
FLOWERING

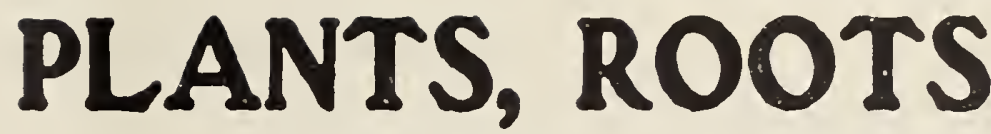

\section{AMARYLLIS}

Splendid flowering bulbs for greenhouse, room, or garden cultivation.

Belladonna Major. Bright pink. Each 15c., per doz. $\$ 1.50$. Prince of Crange. Orange intermingled with white and green. Each 50c., per doz. $\$ 5.00$.

Formosissiura. Crimson. Each $10 \mathrm{c}$, per doz. $\$ 1.00$

Jolunsonii. Very large flower, rich crimson-scarlet color, striped with white. Each $30 \mathrm{c}$, per doz. $\$ 3.00$.

\section{TUBEROUS BEGONIAS}

This charming class of Begonias is perhaps the handsomest of all summer-flowering, tuberous-rooted plants, and deserve much greater popularity. Improvements made in recent years in size, texture and coloring are really phenomenal, with flowers frequently measuring from $4 \frac{1 / 2}{2}$ to 6 inches across, and colors ranging from the purest white and the most delicate tints of pink, yellow and orange to the most intense scarlet and richest crimson while the double-flowering sorts are perfect rosettes, full and double to the center. Their culture is of the sim-

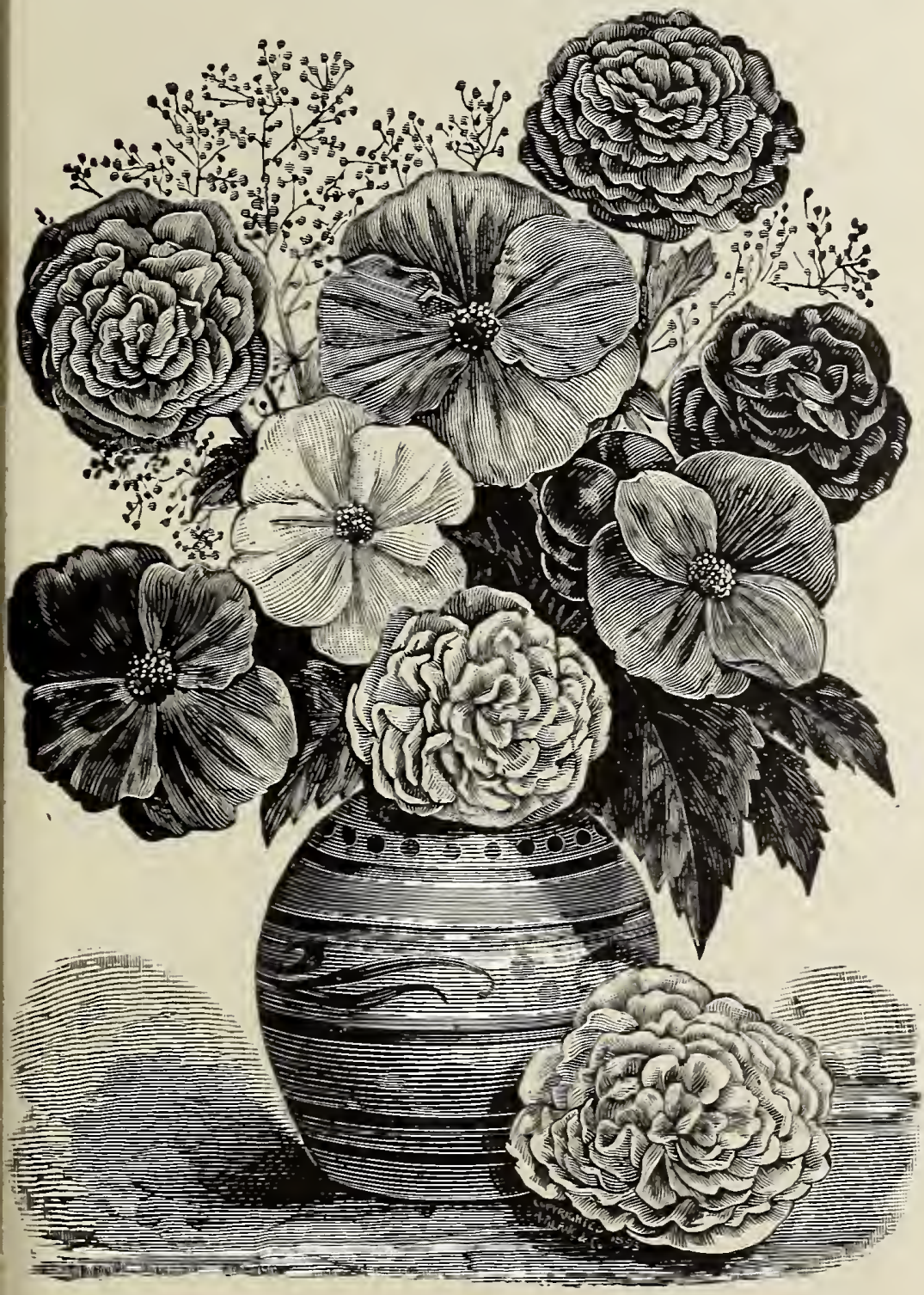

BEGONLAS-TUBEROUS BOOTED plest, and, with the least regard for their requirements, will repay with an abundance and brilliancy of bloom not equalled by any other class of plants; they delight in a rich, mellow, well-drained soil, where they can be liberally supplied with water, preferably in a position where they will be shaded from the direct rays of the sun during the hottest hours of the day, and will succeed equally well grown as pot plants for the conservatory or window garden. On the approach of cold weather the tubers should be taken up, and, after drying, stored away in dry sand or similar material in a cool place, free from frost until spring.

\section{SINGLE SORTS.}

Scarlet, Pink, Orange, White, Crimson, Yellow. Each $10 \mathrm{c}$, per doz. $\$ 1.00$, per $100 \$ 6.00$.

Single, All colors Mixed. Each 8c., per doz. 7 j., per $100 \$ 5.00$.

DOCBLE SORTS.

Scarlet, White, Pink, Ycllow. Each 20c., per doz. $\$ 2.00$. Double, All colors Mixed. Each $15 \mathrm{c}$, per doz, $\$ 1.50$.

\section{CALADIUM ESCULENTUM}

\section{(Elephant's Ear.)}

Our bed of Caladium Esculentum bordered with the new red pennisetum was awarded a Silver Medal at St. Louis, 1904.

One of the most effective plants in cultivation for beds, borders or for planting out upon the lawn; it will grow in any good garden soil, and is of the easiest culture. To obtain the best result it should be planted where it will obtain plenty of water and an abundance of rich compost. Follage light green. Then full size it stands 6 to 10 feet high, and bears immense leaves, 3 to 4 feet long by $2 \frac{1}{2}$ fect wie.

Extra large bulbs. Each 25c., per doz. $\$ 2.50$, per 100 $\$ 15.00$

First-size bulbs. Each 15c., per doz. $\$ 1.50$, per $100 \$ 10.00$. Second-size bulbs. Each 10c., per doz. $\$ 1.00$, per 100 $\$ 7.50$.

Third-size bulbs. Each 7c., per doz. 75c., per $100 \$ 5.00$. If wanted by mail, add 7c., 8c., 10c. and $15 \mathrm{c}$. each according to size, for postage.

\section{FANCY CALADIUMS}

Fancy-leaved Caladiums have, in recent years, grown very rapidly in popular favor, not only for the decoration of the conservatory, greenhouse and window-boxes. but nearly all of the varieties succeed admirably if planted out of doors, when the ground has become warm, in partly shaded, sheltered borders, in well-enriched light soil, while for exhibition plants at fairs, etc., during the summer and fall months nothing can equal their beauty. Finest mixed varieties. Each $15 \mathrm{c}$., doz. $\$ 1.50$, postpaid.

\section{CALLA LILIES}

New Golden Yellow Calla (Richardia Elliottiana). Entirely distinct and unlike all other forms of yellow Callas; it has the same habit of growth as the ordinary white variety, with flowers of same size and shape, but of a rich, clear, lustrous golden-yellow color; the foliage is dark green. With a number of translucent creamy-white spots, which add much to its beauty. Strong bulbs, each 50c., per doz. $\$ 5.00$.

Spotted-leaf Calla (Richardia alba maculata). The leaves of this variety are deep green, with numerous white spots, which give the plant a very ornamental appearance. The flowers are pure white, with a black center; they grow freely either indoors or out. Each $10 \mathrm{c}$., per doz. $\$ 1.00$. 


\section{Summer Flowering Bulbs, Plants and Roots-Continued}

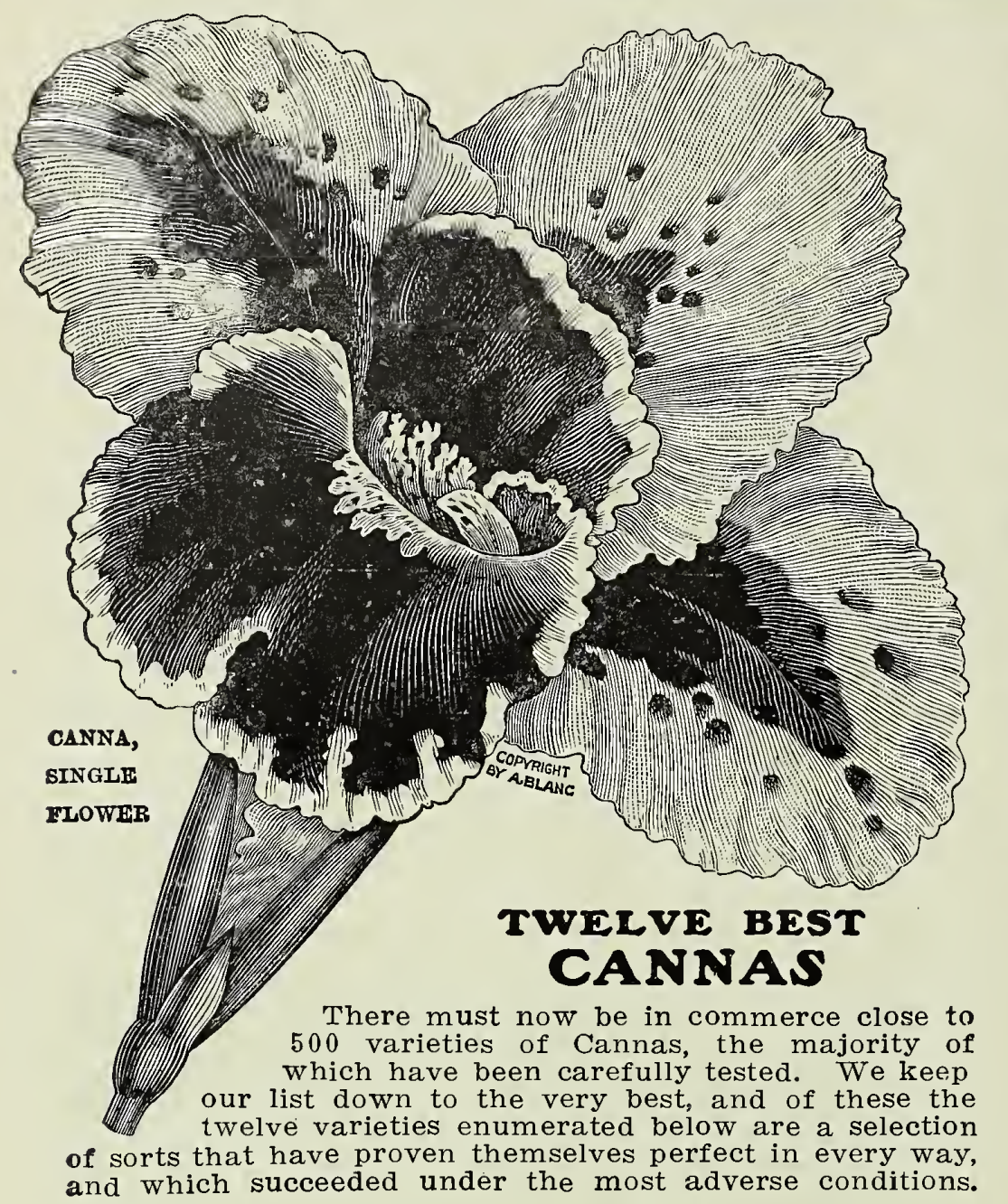

All are of uniform, vigorous growth, and whether planted singly or in masses will make a display certain to give full satisfaction. Each I0c., ber dozen \$1.00.

Alphonse Bouvier. Finest tall brilliant crimson, foliage green; 6 to 7 feeat.

Alsace. Pale sulphur, changing to creamy white; planted in conjunction with the high-colored sorts it makes a fine contrast; foliage green; $4 \frac{1 / 2}{2}$ feet.

President MeKinley. Brilliant crimson with scarlet shadings; a grand dwarf variety, never exceeding 3 feet; foliage green.

Buttercup. The nearest approach to a clear yellow; 3 feet.

David Harum. Bright, deep satiny vermilion; fine bronze foliage; $3 \frac{1}{2}$ feet.

Duke of Marlborough. The finest of the very deep crimsons; fine individual blooms in large trusses, and exceptionally free-flowering and attractive; foliage green; 4 feet.

Egandale. A favorite bronze leaved sort with soft currant-red flowers; 4 feet.

Florence Vaughan. Bright, rich golden-yellow, spotted with red, of large size and perfect form; foliage green; 4 feet.

Mme. Crozy. The popular bright scarlet with golden edge; foliage green; 4 feet.

West Virginia. Intense crimson-scarlet, with broad golden-yellow border; foliage green; 3 feet.

Harry Laing. Exceedingly large, well rounded flowers of rich glowing scarlet suffused with orange; 5 feet.

Mlle. Berat. The nearest approach to a pink in a firstclass bedder; foliage green; 4 feet.

\section{CYCLAMEN}

Cyclamen giganteum. Rose-crimson, white, white and pink eye. Each 20 c., per doz. $\$ 1.75$, per $100 \$ 10.00$.

\section{DAHLIAS}

\section{HRIEMHILDE Pink Cactus Dahlia}

See illustration front cover of catalogue.

No Dahlia heretofore introduced has met with such popular favor as Kriemhilde. In color a brilliant pink and white, the outer edge being pink, gradually shading lighter to the center which is at first a creamy white, changing to pure white. It is of sturdy habit and free growth, producing freely and continuously its exquisite blooms on long stems, making it an ideal flower for cutting. Each $20 \mathrm{c}$, , per doz. $\$ 2.00$, per $100 \$ 15.00$.

\section{CACTUS DAHLIAS}

Aunt Chloe. Dark maroon shaded black with narrow pointed petals.

Atlanta. Large bright rich red shaded darker.

Brunhilde. Color, deep plum, rich and velvety.

Bridesmaid. Pale primrose shading to pink.

Countess of Lonsdale. Extremely profuse bloomer, color blending of amber and salmon pink.

Earl of Pembroke. Bright plum, deeper and more velvety toward the center.

Gabriel. Color, shades of scarlet and cinnamon; sometimes the petals are tipped white.

General Buller. Color deep rich velvety maroon, tipped white.

J. H. Jackson. The largest and finest of the deep velvety maroons. The above $20 \mathrm{c}$. each, $\$ 2.25$ per doz.

Kriemhilde. Color is a fresh delicate pink shading to deep rose pink. A valuable acquisition as a cut flower.

Volker. Clearest canary yellow, an easy and profuse bloomer.

vinsome. Best white cactus to date; flowers are very large with twisted incurved petals.

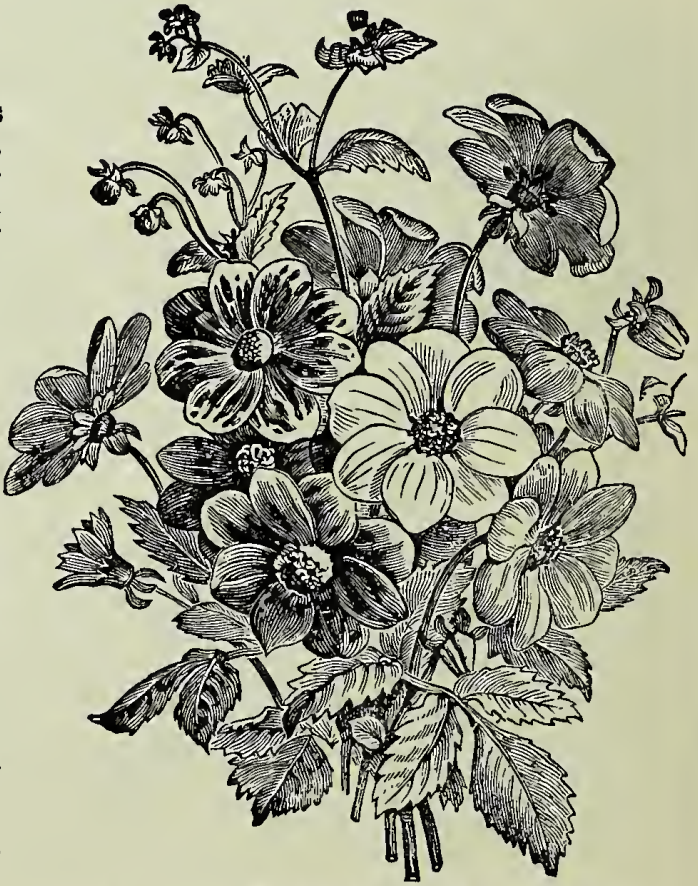

DAHLIA-CLUSTER OF SINGLE FLOWERS 
Summer-Flowering Bulbs, Plants and Roots-Continued

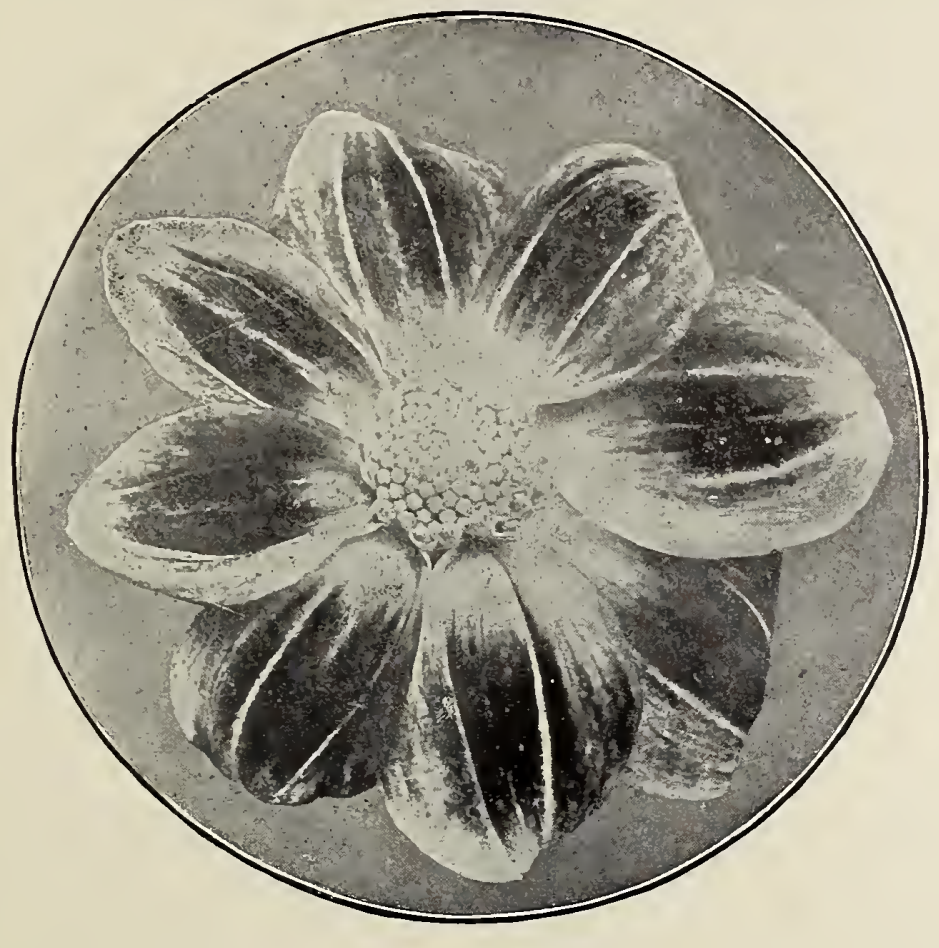

\section{SINGLE DAHLIAS}

Ami Barrillet. Color a rich dark garnet with purplish maroon foliage.

Buttercup. Dright jellow richly shaded.

Fashion. Crimson maroon flamed purple, light disc.

Gracie. Color is a snow white suffused a delicate blush shading to pink at the center of the fiower.

Gold Standard. Clear canary yellow; a very profuse bloomer.

John Downie. Intense crimson scarlet.

Nellie. Rosy purple with white disc flowers borne on long stems. Willie. Bronzy yellow striped scarlet, sometimes tipped white.

20th Century. The color, intense rosy crimson with white tins and disc around the yellow center. Considered one of the finest single varieties.

The above $20 \mathrm{c}$. each, $\$ 2.25$ per doz.

\section{MIXED DAHLIAS}

Four colors, 10c. each, $\$ 1.00$ per doz.

\section{GLADIOLUS}

AMERICA. One of the finest varieties ever offered in recent years. For cutting or bedding it is unsurpassed. The color is a beautiful soft flesh pink. Its growth and labit are perfect. Those who planted this variety have nothing but praise to offer. Each 15c., per doz. $\$ 1.50$, per $100 \$ 10.00$.

Our line of Gladioli are the best in their class.

Pink Shades. Each 5c., per doz. 40c., per $100 \$ 2.25$.

White and Light Shades. Each $6 \mathrm{c}$, per doz. $60 \mathrm{c}$, , per $100 \$ 4.50$.

Golden Yellow Shades. Each 6c., per doz. 60c., per $100 \$ 4.50$.

Scarlet and Crimson Shades. Each 3c., per doz. 25 c., per $100 \$ 1.75$.

Best Mixed. Per doz. 25c., per $100 \$ 1.50$, per 1000 $\$ 10.00$.

If by mail, add 10c. per dozen for postage.

PRICES ON 1000 LOTS, QUOTED UPON APPLICATION.

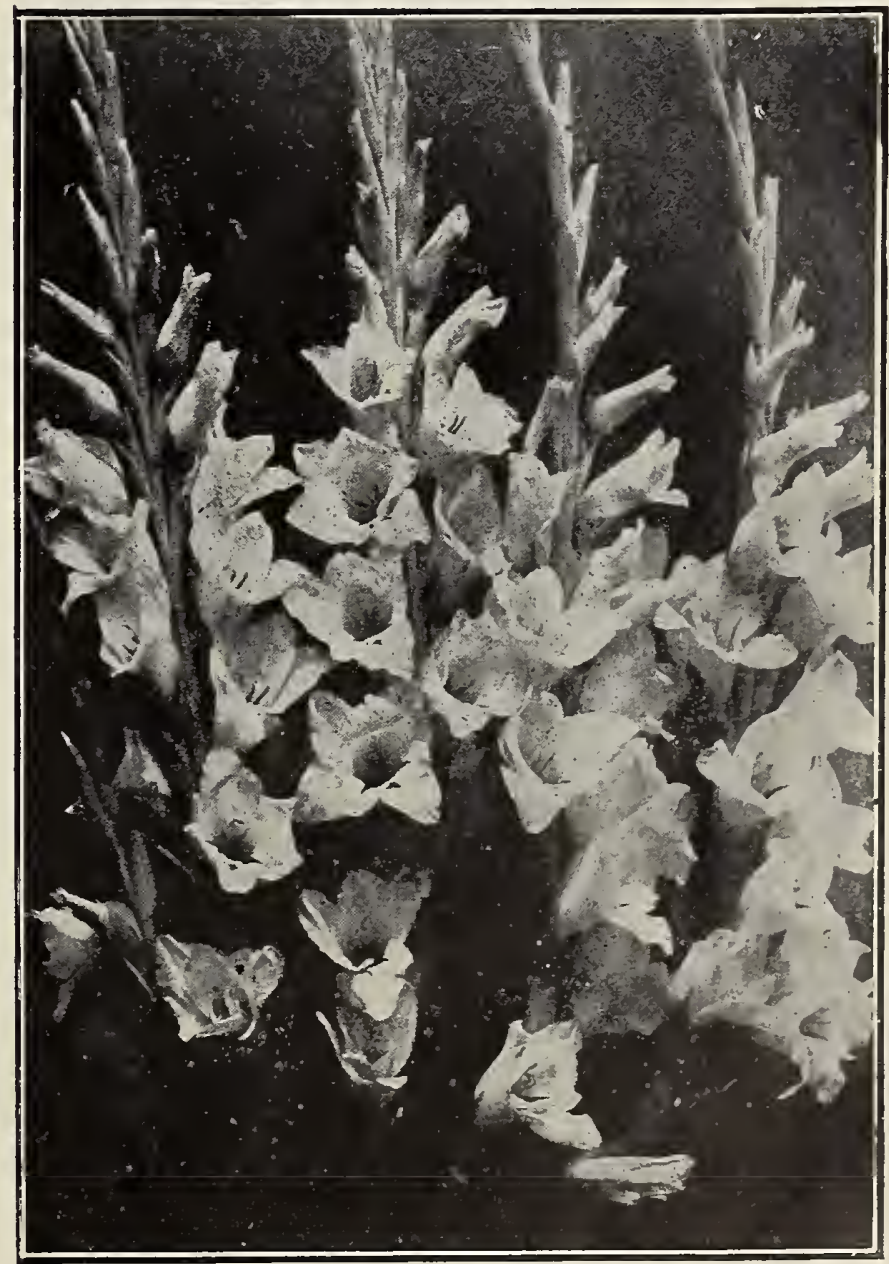

GLADIOLOS 
Summer-Flowering Bulbs, Plants and Roots-Continued

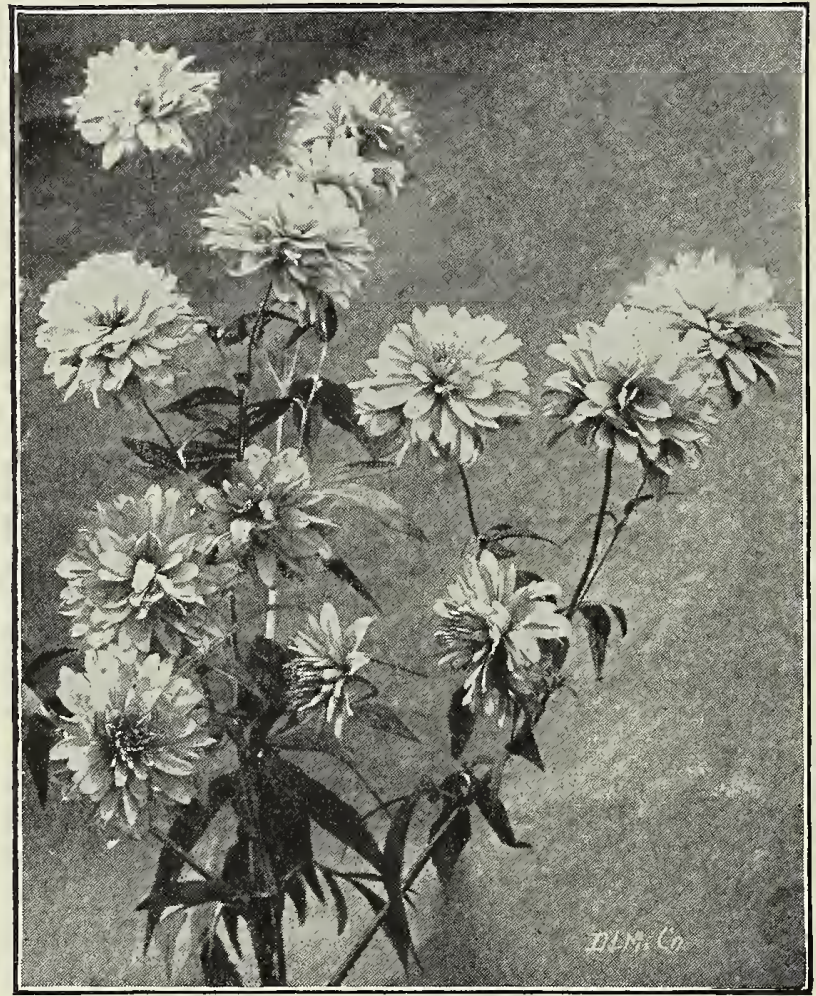

GOLDEN GLOW

\section{GOLDEN GLOW CONE FLOWER}

One of the showiest flowers cultivated. Makes one solid mass of golden yellow flowers during the Summer and early Fall. Perfectly hardy. The roots multiply rapidly. Each 15c., per doz $\$ 1.50$.

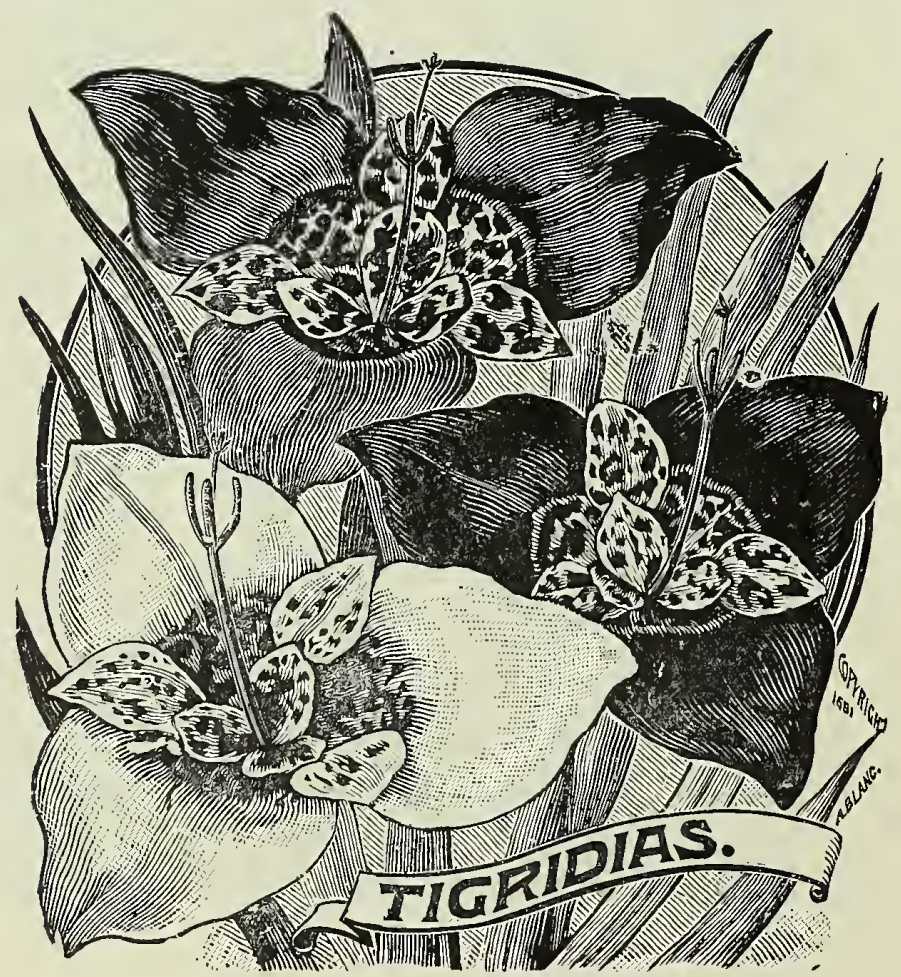

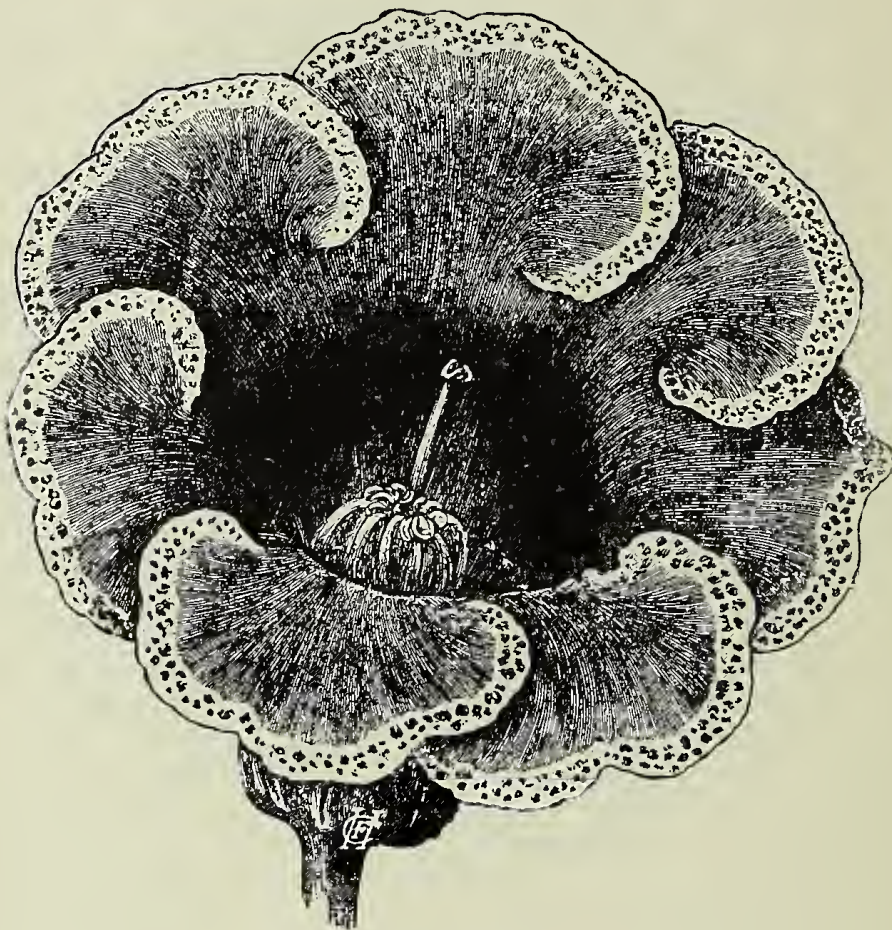

GLOXINIA

\section{SELECT GLOXINIAS}

This charming class of Summer-flowering bulbs is now so well known that a lengthy description of them is unnecessary. They delight in a loose, porous soil composed of equal parts of fibrous loam and leaf mold to which has been added a liberal sprinkling of thoroughly decayed, well-pulverized manure or bone meal and sharp sand. They should be shaded from the direct rays of the sun, but exposed to as much light as possible. Our collection embraces all the popular varieties, ranging in color from the purest white through all the shades of crimson and purple, spotted and mottled. Each 15c., per doz. $\$ 1.50$, per $100 \$ 10.00$.

\section{TIGRIDIAS}

One of the most showy of all Summer bulbs, and blooms from Midsummer until frost, growing three feet high, with large, wide-open triangular blooms, four to six inches across.

Conchiflora. Dark yellow, large red spots.

Pavonia Grandiflora. Large, bright crimson, center mottled with yellow.

Grandiflora Alba. Pearly white, with a yellow cup gorgeously spotted with crimson. Each 5c., per doz 50c., per $100 \$ 4.00$, postpaid. 
Summer Flowering Bulbs, Plants and Roots-Continued

\section{ISMENE CALATHINA}

(Pancratium.)

A grand summer-flowering bulb, producing throughout the season large Amaryllis-like, pure white, fragrant blossoms. Keep the bulbs in a dry, warm place, and plant out in June. Bulbs can be taken up in October, and, after a few weeks' rest, potted and fowered in the house in winter, or liept over for planting out another season. Each $25 \mathrm{c}$, per doz. $\$ 2.50$.

\section{MADEIRA MIGNONETTE}

Or Mexican Vine.

The old favorite, "Climbing Mignonette." Thick, glossy" leaves, and long, hanging stems of feathery, fragrant, white flowers. Each 5c., doz. 50c., $100 \$ 3.50$, postpaid.

\section{MONTBRETIA}

This is one of the most floriferous and showy of summer-flowering plants, and destined to great popularity. Planted 6 inches apart in a group in a sunny position and allowed to remain undisturbed for several years, they form magnificent clumps, producing, in great numbers, oraceful spikes bearing from 18 to 30 showy star-shaped flowers of orange suffused with red. They flower freely the first season. Price, 3 for $10 \mathrm{c}$, doz., $30 \mathrm{c.,}, 100 \$ 2.00$.

\section{SUMMER FLOWERING OXALIS}

No bulb is so valuable for edging the borders of walks or flower beds as the beautiful flowering Oxalis. When planted three inches apart they produce an unbroken row of elegant foliage and pretty flowers; and as they bloom very quickly after planting they furnish a neat and attractive border the whole season. They are also splendid when planted in a mass, and make a very showy bed. The bulbs, which are the size of peas, or larger, can be planted the first of May, or perhaps earlier, and will be in bloom by the first of June.

Dieppi. Pure white; very fine.

Lasandria. Fine rosy pink, beautiful cut foliage.

Shamrock. Lovely clover-like foliage and pink blossoms.

Each 5c., doz. 50c., postpaid.

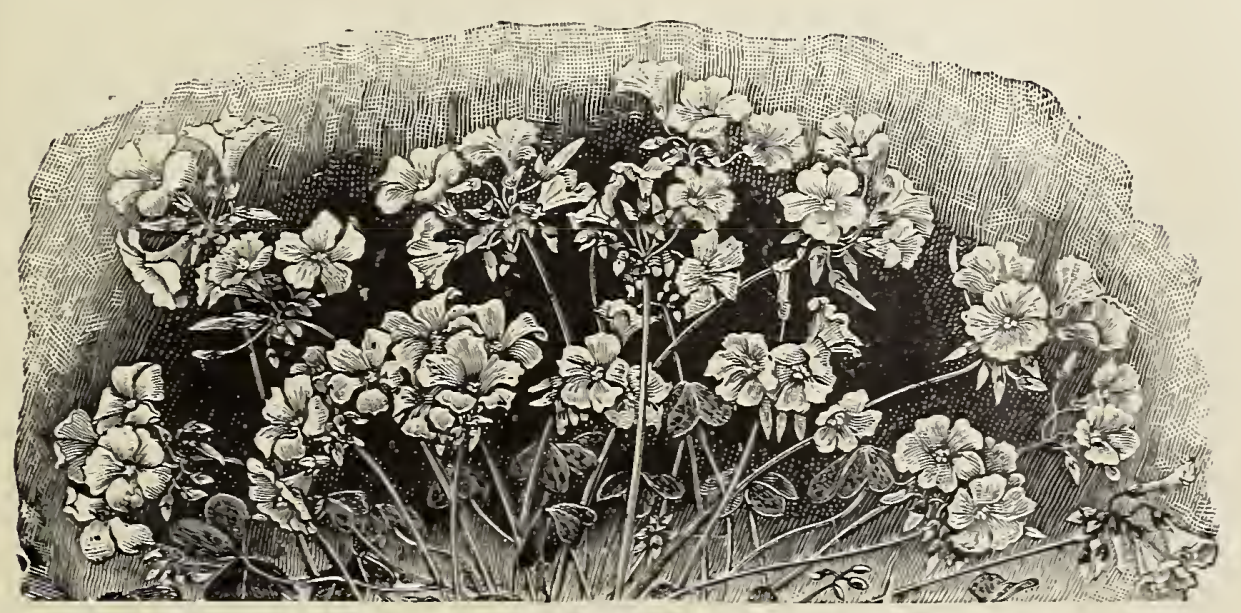

OXALIS

\section{HYACINTHUS CANDICANS}

\section{(Cape Hyacinth.)}

A snow-white summer-flowering Hyacinth, growing 3 to 5 feet in height, gracefully surmounted with from 20 to 30 pure white bell-shaped flowers. Each 5c., per doz. 50c.; by mail, 10c. per doz. extra.

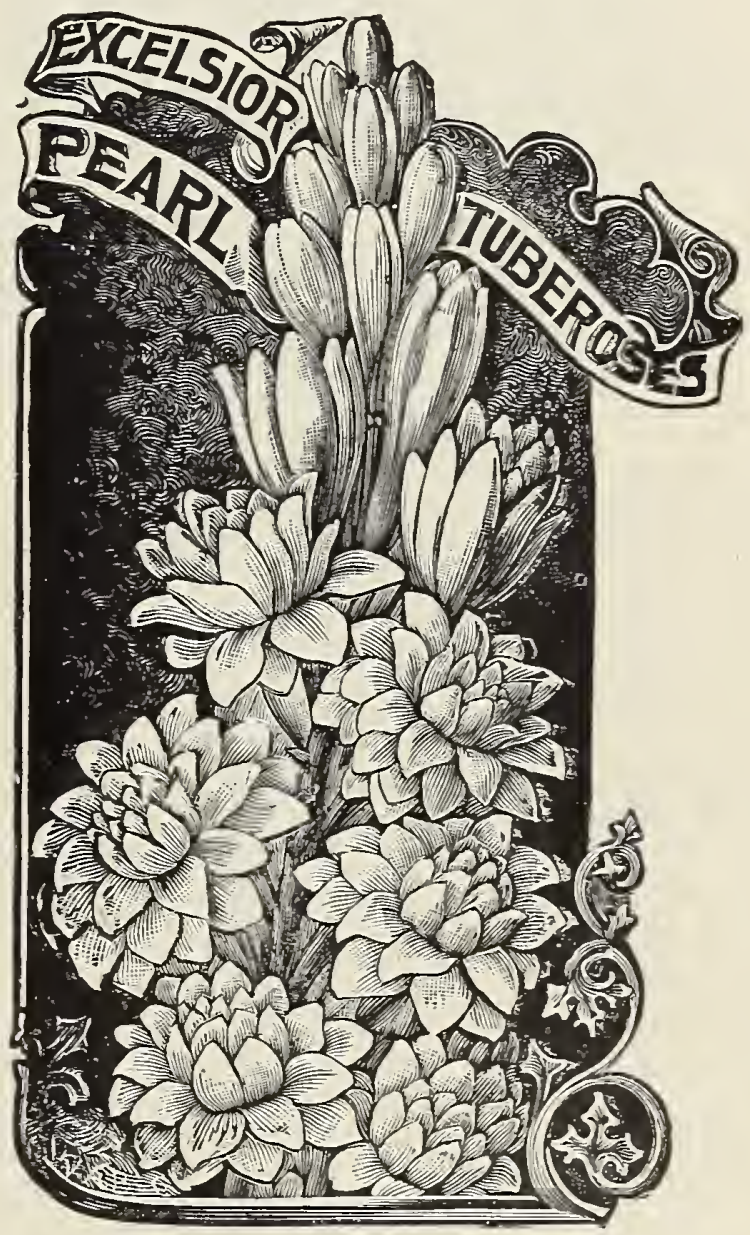

\section{TUBEROSES}

(New Excelsior Pearl Tuberose.)

The New Excelsior Pearl Tuberoses have been selected with great care and are superior to the ordinary Pearl Tuberoses. This variety is characterized by its short, robust stem and long spikes of large flowers in great profusion, perfectly double and twice the size of the common tuberose, while of equally delicious fragrance. Largest size, selected bulbs, each 5c., doz. 30c., $100 \$ 2.00$, postpaid.

Drrarf Pearl. Each 3c., doz. 20c., 100 \$1.25; add 5 c. per doz. postage. 


\section{HARDY PERENNIAL PLANTS}

Known as old=fashioned hardy garden flowers. Have come into public favor so rapidly as to astonish even the most sanguine enthusiasts of the se gems of the garden. Their popularity is not at all surprising when we consider the many varied and pleasant changes which take place throughout the entire growing season in a well=arranged hardy border in which every week brings forth something fresh and new. We have listed what we believe to be the most popular varieties of hardy plants and shall continue adding every year such varieties as are desirable.

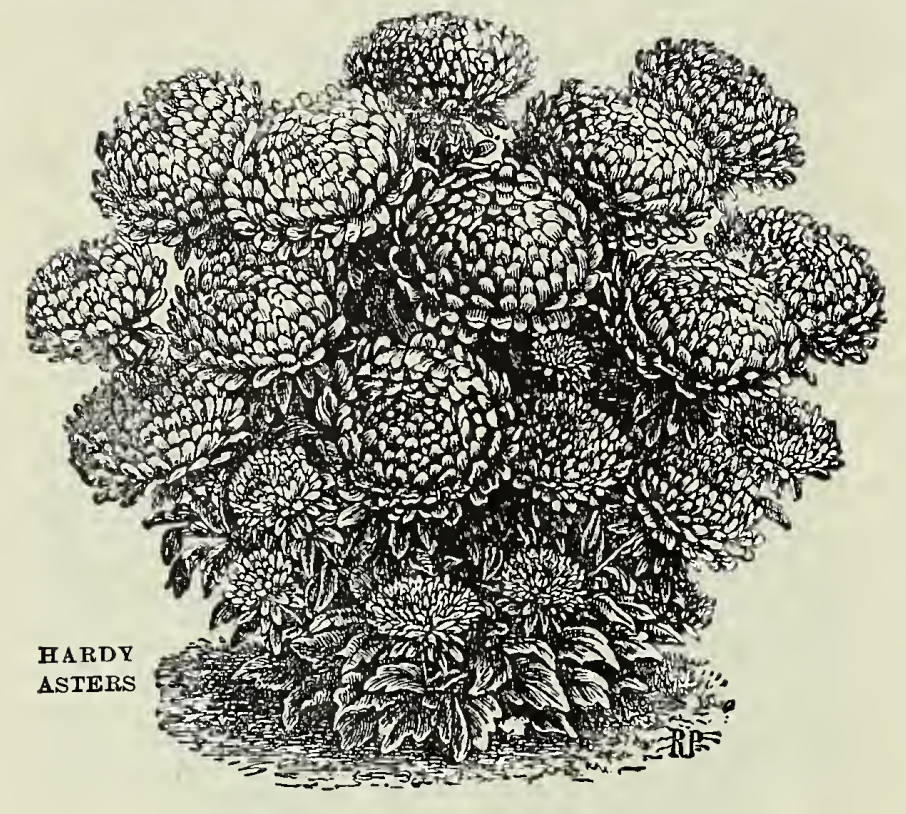

\section{Hardy Asters}

These are among the showiest of our late-flowering hardy plants, giving a wealth of bloom at a season when most other hardy flowers are past. All varieties in mixture. Each $15 \mathrm{c} .$, per doz. $\$ 1.50$.

\section{Aquatics-Water Lilies-Hardy Varieties Nympheas}

Alba. White. Each 50c., per doz. $\$ 5.00$.

Candidissima. White, flushed pink. Each $50 \mathrm{c}$, per doz. $\$ 5.00$.

Odorata. Fragrant white. Each $20 \mathrm{c}$., per doz. $\$ 2.00$.

Gigantea. White. Each $20 \mathrm{c}$., per doz. $\$ 2.00$.

Rosea. Pink. Each $50 \mathrm{c}$, per doz., $\$ 5.00$.

Sulphurea. Yellow. Each 50c., per doz. $\$ 5.00$.

\section{Nelumbiums}

Speciosum. Rose and white. Each 75c., per doz. $\$ 7.50$. Luteum. Yellow. Each 75c., per doz. $\$ 7.50$.

Roseum. Deep pink. Each $\$ 1.00$, per doz. $\$ 10.00$.

\section{Aquilegia}

\section{(Columbine.)}

The Columbines are old favorites late spring and early summer blooming plants, growing about 2 feet high, that succeed in any ordinary garden soil. The varieties offered are a selection of the best kinds.

Californica Hybrida. One of the finest mixtures ever brought together. Each 15c., per doz. $\$ 1.50$.

\section{Bleeding Heart}

(Dielytra Spectabilis) Hardy.

The old Bleeding Heart is the flower of our childhood, which is as lovely to-day as then, though not so common. Bears in early spring long, graceful chains of pendulous bloom of exquisite beauty. Fine for winter blooming in pots. Large roots, each $15 \mathrm{c}$., per doz. $\$ 1.50$. If by mail, add $5 \mathrm{c}$. each for postage.

\section{Campanula}

Campanula (Bell Flower). An assortment of all varieties. Each 15c., per doz. $\$ 1.50$.

\section{Caryopteris}

Mastacanthus (Blue Spiræa). A handsome hardy perennial; grows about 3 feet high and produces rich lavender-blue flowers in great profusion the whole length of its branches. A valuable plant either for bedding or pot culture, blooming continuously from early in September until cut by frost. Each $15 \mathrm{c}$., per doz. $\$ 1.50$.

\section{Cerastium}

(Snow in Summer.)

Tomentosum. A desirable low-growing plant with silvery foliage and white flowers, suitable for the rockery, or for carpeting dry, sunny spots, such as covering graves or steep banks; can also be used with good effect in carpet bedding. Each $15 \mathrm{c}$, per doz. $\$ 1.50$.

\section{Hardy Pompon Chrysanthemums}

These beautiful varieties are now universally popular for outdoor bedding, and, considering their many good qualities, there is no cause for surprise to see them cultivated so extensively. They produce a lavish profusion of blooms, giving color, life and beauty to the garden just at a time when other plants have been destroyed by frost and are looking their worst. Frost does not materially affect the flowering, and it will frequently happen that an armful of flowers can be cut late in November. They are quite hardy, and, with but a slight covering of leaves or litter during the winter, will take care of themselves after once planted. All varieties in mixture, each $10 \mathrm{c}$, per doz. $\$ 1.00$.

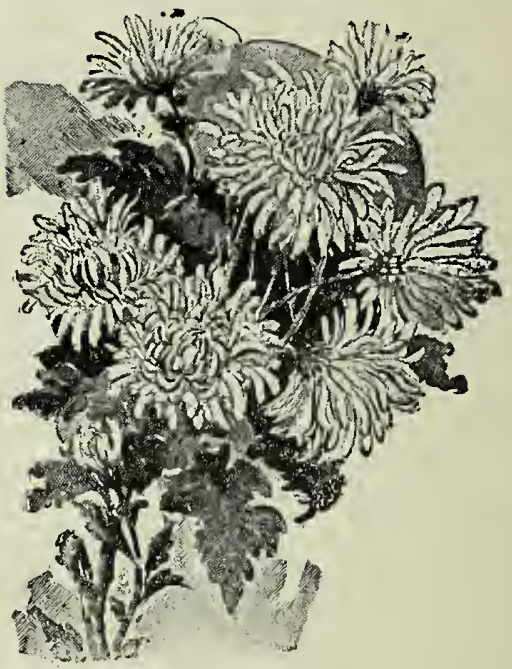

HARDY POMPON

\section{Funkia \\ (Plantain Lily.)}

The Plantain Lilies are among the easiest plants to manage; their broad, massive foliage makes them attractive subjects for the horder even when not in flower; they deserve extensive cultivation. Each 15c., per doz. $\$ 1.50$.

\section{Helianthus}

(Hardy Sunflowers.)

The perennial Sunflowers are among the most effective hardy plants for large borders, for planting among shrubbery, or as clumps on the lawn. They are remarkably free-flowering, will succeed in any soil, and are invaluable for decorative purposes or as cut flowers during the summer. All varieties. Each $15 \mathrm{c}$., per doz. $\$ 1.50$. 


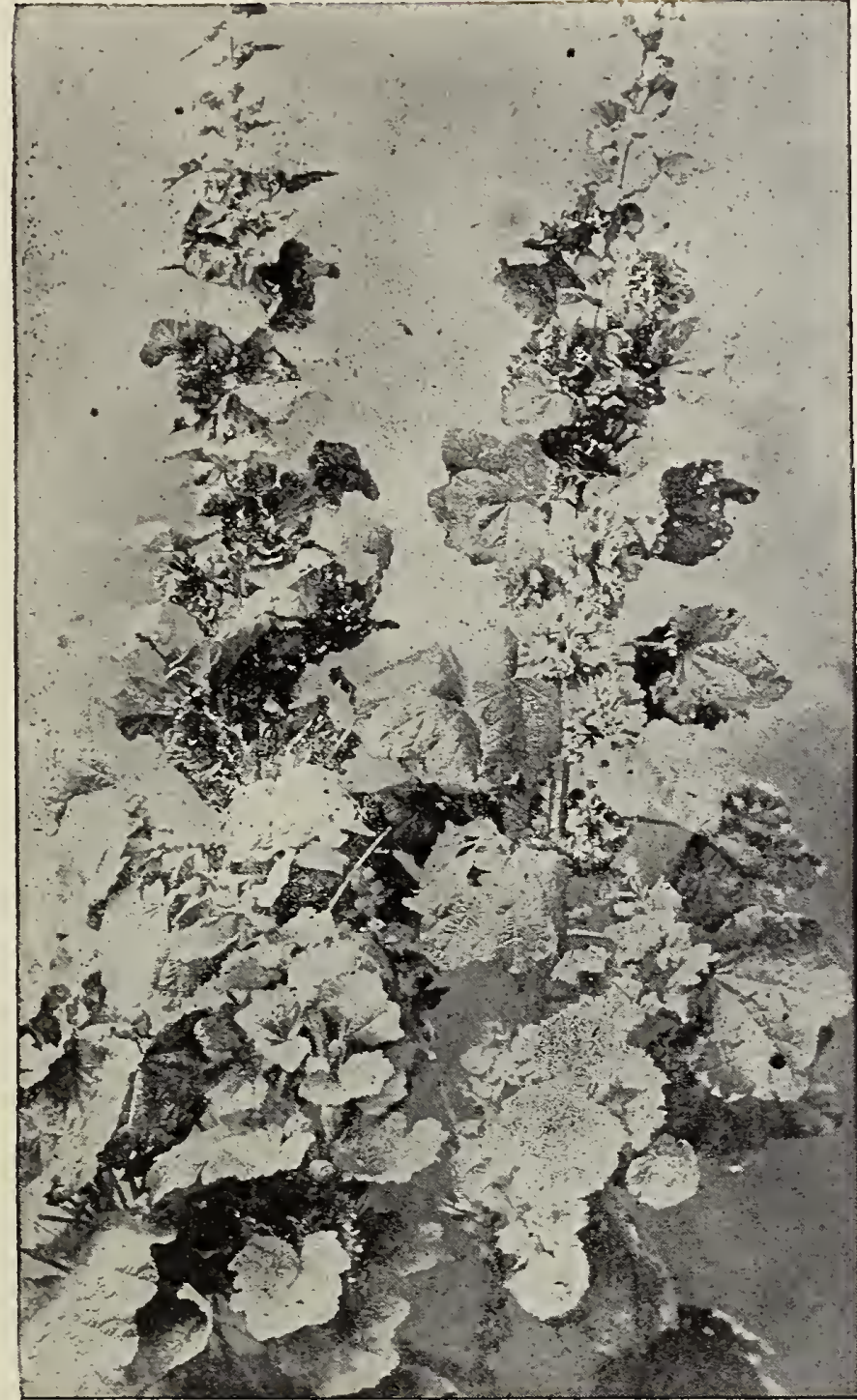

HOLLYHOCKS

\section{Noll's Superb Hollyhocks}

Few hardy plants combine as many good qualities as the Hollyhock. For planting in rows or groups on the lawn, or for interspersing among shrubbery, they are invaluable. The flowers form perfect rosettes of the most lovely shades of color. The Hollyhock requires a rich deep soil, well drained and will repay in quantity and elegance of bloom any extra care. A slight protection during the winter will be beneficial. (See cut.)

We offer strong plants, which will flower this season.

Double IVhite. Pink. Salmon. Yellow, Maroon and Bright Red. Each 20 c., per doz. $\$ 2.00$.

Double Mixed Colors. Each 15c., per doz. $\$ 1.50$.

For Everblooming annual varieties see page 51 .

\section{Japanese Iris}

(Iris Krempferi.)

These magnificent Iris are among the most beautiful of our summer-flowering plants, and are becoming more popular every season. They commence blooming about the middle of June and continue five or six weeks. Many of these flowers measure from 10 to 12 inches in diameter, and rival the orchids in their rich colorings and markings. Should be planted in a rich moist position, abundantly supplied with manure and water. Extra choice mixed varieties. Each $15 \mathrm{c}$., per doz. $\$ 1.50$.

\section{Lilium}

(Lily.)

All herbaceous borders should have a few Lilies scattered through them, including Auratum, Candidum, Speciosum varieties, etc., etc. The sorts offered below can be planted with excellent results during the spring months. It is in the hardy border that Lilies do best, as they get the benefit of the shade of the surrounding plants, which is so necessary to their welfare.

Auratum (Gold-banded Lily). Large, graceful flowers, composed of six petals of a delicate ivory-white thickly studded with chocolate-crimson spots, and striped through the center a golden-yellow. Each 20c., per doz. $\$ 2.00$, per $100 \$ 12.00$.

Speciosum Album. Large white flowers of great substance, with a greenish band running through the center of each petal. Each 20c., per doz. \$2.00, per 100 $\$ 12.00$.

Speciosum Rubrum, or Roseum. White, heavily spotted with rich rosy crimson spots. Each $20 \mathrm{c}$., per doz. $\$ 2.00$, per $100 \$ 12.00$.

Tigrinum Splendens (Tiger Lily). Very large flowers: orange, spotted black. Each 12c., per doz. \$1.25, per $100 \$ 8.00$

If Lily bulbs are wanted by mail, add 5 cents per bulb for postage.

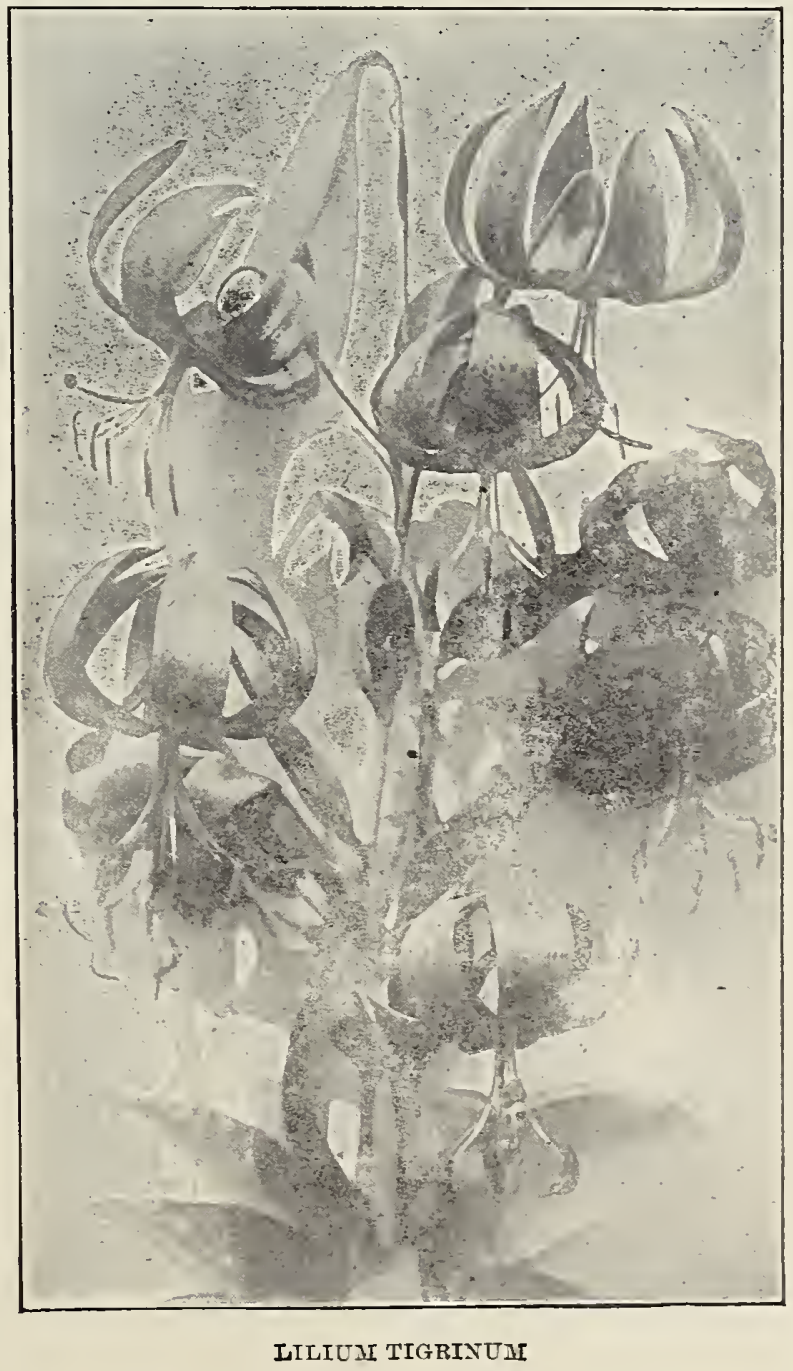

Lily of the Valley

Pips, per doz. 30c., per $100 \$ 2.00$. Clumps, each $30 \mathrm{c}$. per doz. $\$ 3.00$. 


\section{Hardy Perennial Plants--Continued}

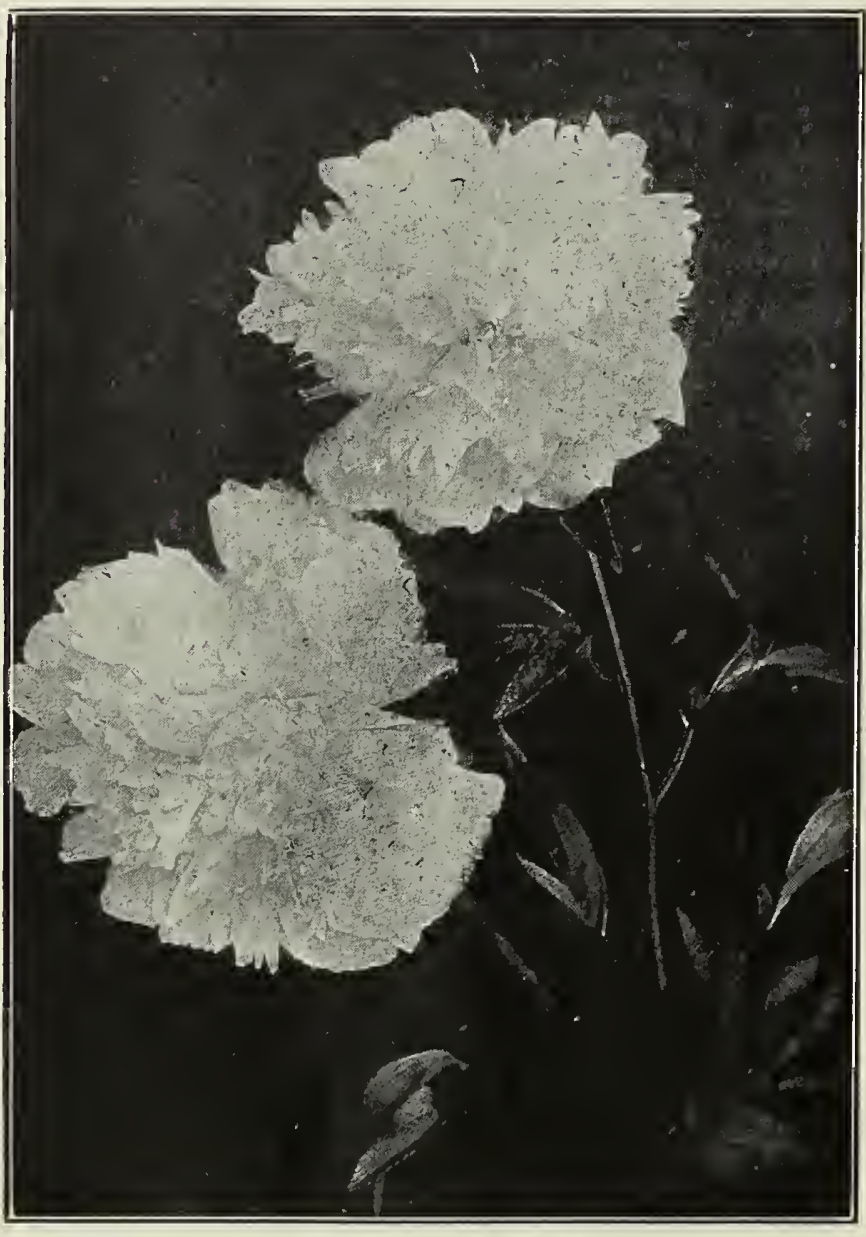

PEONY, MONT BLANC

\section{Peonies}

The Herbaceous Peonies have always held an important place among hardy plants, and with the wonderful improvements made during recent years have established themselves among the leaders for popular favor. They are perfectly hardy, requiring no protection whatever even in the most severe climate, are not troubled with insect pests or disease of any kind, and once planted take care of themselves, increasing in beauty each year. Three colors, red, white, pink. Each 20 c., per doz. \$2.25. Any named variety supplied at regular prices.

\section{Japanese Tree Peonies}

Differ from the herbaceous varieties in their growth, which is in the form of a dwarf shrub. Different colors. Each $\$ 1.00$, per doz. $\$ 10.00$.

\section{Hardy Phloxes}

(Fall-Blooming.)

These grand, hardy, flowering plants are becoming very popular and deservedly so. They are of the easiest culture, and during the late summer and fall months make the garden bright with their wealth of bloom. Any color desired. Each $15 \mathrm{c}$, per doz. $\$ 1.50$.

\section{Hardy Garden Pinks}

Old favorites, bearing their sweet, clove-scented flowers in the greatest profusion during May and June; 1 foot, Each 10c., per doz. $\$ 1.00$

\section{Papaver \\ (Poppy.)}

Nudicaule (Iceland Poppy). These range in color from the purest white and yellow to the deepest orange- scarlet. The plants form tufts of fern-like foliage, from amongst which the slender flower-stalks rise to about a foot in height, and bear elegant cup-shaped flowers. The profusion of blooms which they produce is really astonishing, often a hundred flower stems on a single plant, and they are produced from the beginning of June to October. Mixed colors. Each 15c., per doz. $\$ 1.50$.

Orientale (Oriental Poppy). Nothing can equal these in gorgeous effect, and, whether planted singly or in masses, their large flowers, rich, brilliant colors and freedom of bloom render them conspicuous in any position. We offer them in mixed colors. Each 15c., per doz. $\$ 1.50$.

\section{Rudbeckia}

\section{(Cone-flower.)}

Golden Glow. We question if any one hardy perennial plant has ever met with greater popularity than this. It is a strong, robust grower, attaining a height of 5 to 6 feet, and produces masses of double golden-yellow Cactus Dahlia-like flowers from July to September. Each 15c., per doz. $\$ 1.50$.

\section{Spirea}

An assortment of varieties of which the Japonica Floribunda is the most popular. Each $15 \mathrm{c}$, per doz. $\$ 1.50$.

\section{Sweet Willam}

\section{(Dianthus Barbatus.)}

Beautiful old-fashioned favorite border plant. The stock we offer has been grown from a select strain; various colors. Each 10c., per doz. $\$ 1.00$.

\section{Tritoma Pfitzerii}

\section{(Ever-blooming "Red Hot Poker Plant.")}

This new variety is a marvelous improvement over the old well-known "Red Hot Poker" plant. It is a very free blooming sort, flowering continuously throughout the season. The flowers are large spikes of brilliant flame-color, with long stalks gracefully poised above the rich green foliage. A bed of this in bloom is a grand sight; a border of it around Cannas is admirable; scattered throughout the flower garden it adds grace and brightness and is in its glory when nearly all other flowers are seared with early frosts. The roots should be dug up before hard frost and kept in sand in the cellar during winter. Each $20 \mathrm{c}$, per doz. $\$ 2.00$.

\section{Hardy Violets}

The varieties listed below, while not suited for forcing, are perfectly hardy, and are covered with flowers in early spring.

Pedata (Bird's-foot Violet). A native variety, with finelycut foliage and showy blue flowers. Each $10 \mathrm{c}$., per doz. $\$ 1.00$, per $100 \$ 6.00$.

Bicolor. An elegant variety of the preceding, with the upper petals a rich royal purple, lower petals almost white. Each 15c., per doz. $\$ 1.50$, per $100 \$ 10.00$.

Double Russian. Fine large double deep purple flowers of exquisite fragrance. Each $10 \mathrm{c}$, per doz. $\$ 1.00$.

\section{Wallflower}

The old favorite fragrant wallflower; mixed colors, including yellow, brown, etc. Each 15c., per doz. $\$ 1.50$, per $100 \$ 10.00$.

\section{Yucca}

(Adam's Needle.)

Filamentosa. Among hardy ornamental foliage and flowering plants this can be classed at the head of the list. Its broad, sword-like foliage and tall, branched spikes of large, fragrant, drooping. creamy-white flowers during June and July make it an effective plant for all positions. Each $25 \mathrm{c}$., per doz. $\$ 2.50$. 


\section{CHOICE HARDY \\ ALTITEA}

\section{(Rose of Sharon)}

The Altheas are among the most valuable of our hardy shrubs on acount of their late season of blooming. which is from August to October, a period during which but few shrubs or trees are in flower. They are also extensively used as hedge plants, for which they are admirably adapied. Each $25 \mathrm{c}$., per doz. $\$ 2.50$.

\section{CALYCANTHUS FLORIDUS}

(Sweet or Strawberry Slrub)

An old favorite, with double chocolate-colored strawverry-scented flowers. Each $25 \mathrm{c}$.

\section{DEUTZIA CANDIDISSIMA PLENA}

A fine double white. Each 25c., per doz. $\$ 2.50$.

\section{DEUTZIA GRACILIS}

A dwarf bush, covered with spikes of pure white flowers in early summer. Each $25 \mathrm{c}$., per doz. $\$ 2.50$.

\section{FORSTTHIA FORTUNEI}

\section{(Golden Bell)}

Of upright growth, broad, deep green foliage and bright yellow flowers in April. Each $25 \mathrm{c}$.

\section{HYDRANGEA PANICULATA GRANDIFLORA}

Without doubt the best known and most popular Shrub in cultivation at the present time. The flowers, which are borne in dense pyramidal panicles a foot long, in greatest profusion, are white when they first open, but gradually change to rose color and remain in good condition for weeks. Fine bush plants, each $25 \mathrm{c}$, per doz. $\$ 2.50$; extra fine bush plants, each $50 \mathrm{c}$., per doz. $\$ 5.00$; standard or tree-shaped plants, which will make beautiful specimens for lawn or garden. Each 50c., per doz. $\$ 5.00$.

\section{MAGNOLIA GLAUCA}

(White Bay or Laurel)

The native Magnolia of the swamps, much admired for the beauty of its foliage and pure white fragrant fowers; 3 to 4 feet. Each $\$ 1.00$.

\section{MAGNOLIA SOULANGEANA}

A Chinese species which, while shrub-like in its young growth, attains the size of a tree in time; its flowers, which are produced early in Spring, are cup-shaped, 3 to 5 inches in diameter, and are white inside, flushed with purple outside. Strong, heavy plants, each $\$ 2.00$.

\section{SYRINGA}

\section{LILAC CHARLES IT}

A strong rapid-growing variety, with large, shining leaves. Trusses rather loose; large reddish-purple. Each $50 \mathrm{c}$.

\section{MARIE LE GRAY} $50 \mathrm{c}$

Beautiful creamy-white flowers of immense size. Each

\section{HEDGE}

\section{CALIFORNIA PRIVET}

Of all ornamental hedge plants, this is the most popular, and more of it is planted than all others combined. Its foliage is a rich dark green, and is nearly evergreen, remaining on the plant until midwinter. It is of free growth, and succeeds under the most adverse conditions, such as under dense shade of trees, where other plants would not exist.

The most advantageous manner of planting is in double rows, the two rows being about 8 inches apart. The
These are exceedingly beautiful, especially in spring and early summer, when they burst into full leaf, and the various colors of the foliage are deep and decided, and in autumn many varieties deepen in color and assume very beautiful tints.

\section{JAPONICUM AUREUM}

Golden-yellow, scalloped leaves. Each $\$ 1.00$.

\section{POLYMORPHUM ATROPURPUREUM}

Purple-leaved variety, deeply cut. Each $\$ 1.00$.

\section{PHILADELPHUS CORONARIUS AUREUS}

(Golden-leaved Mock Orange)

Fine golden-yellow foliage contrasting beautifully with the dark leaves of other Shrubs. Each $25 \mathrm{c}$.

\section{PRUNUS JAPONICA FI. PL.}

\section{(Double Flowering Almond)}

A beautiful dwarf Shrub, producing its showy double flowers early in Nay before the leaves appear. We can supply both white and pink. Each $35 \mathrm{c}$.

\section{PYRUS JAPONICUS}

(Japan Quince)

A very showy and popular Shrub, which blooms profusely in early spring; flowers dazzling scarlet. Makes an excellent hedge. Each $25 \mathrm{c}$, per doz. $\$ 2.50$.

\section{HARDY RHODODENDRONS}

One of the most valuable of our hardy decorative plants. They require only a good garden soil, which should be dug at least 2 feet deep and mixed with some leaf mould or peat; it is also well to mulch the ground during summer, and protect with leaves or brush during the winter.

We offer below but a limited list of varieties, which, however, is a selection of the hardiest sorts in cultivation. Bertie Parsons. Delicate lilac.

Catawbiensis Alba. White.

Grandiflorum. Rosy red.

Lady Armstrong. Bright rose.

We can furnish any of the above in strong, bushy plants, 18 inches high. well set with buds, each $\$ 1.50$, per doz. $\$ 15.00$.

\section{OR LILACS}

\section{VIBURNUM PLICATUM}

(Japan Snowball)

One of the choicest hardy Shrubs, with healthy dark foliage; the perfect balls of pure white flowers are borne in great profusion; a decided improvement on the old Snowball; very desirable. Each $50 \mathrm{c}$.

\section{PLANTS}

smallest size plants here offered should be set 10 to 12 inches apart in the row-alternating the plants-while the larger sizes may be set 12 to 15 inches apart. In order to secure a dense hedge from the base up, the plants should be severely pruned the first two seasons. Per 100 Per 1000 Strong 1-year-old, 18 to 24 inches high....\$3 50 $\$ 3000$ Strong 2-year-old, 24 to 30 inches high.... $500 \quad 4500$ Strong 2-year-old, 30 to 36 inches high.... $700 \quad 5500$ 
J. F. NOII \& CO.,

115 Mulberry St., Newark, N. J.

\section{HARDY CLIMBING PLANTS}

\section{AMPELOPSIS VEITCHI}

(Boston Ivy, or Japan Ivy.)

The most popular and desirable climbing plant for covering brick, stone or wooden walls, trees, etc. After it becomes established at the roo it is of very rapid giowth, and clings to the smoothest surface with the tenacity of ivy; the foliage is of a rich olive-greten during the summer, changing to various shades of ironze, crimson and scarlet in the fall. Extra strong plants, each $25 \mathrm{c}$, per doz. $\$ 2.50$.

\section{ARISTOLOCHIA SIPHO}

(Dutchman's Pipe Vine.)

A vigorous and rapid-growing climber, bearing singular brownish-colored flowers, resembling in shape a pipe. Its flowers, however, are of little value compared to its fine light-green leaves, which are of very large size, and retain their color from early spring to late fall; perfectly hardy. Extra strong plants, each 50c., per doz. $\$ 5.00$.

\section{CINNAMON VINE}

(Dioseorea Batatas.)

A rapid-growing climber, taking its name from the peculiar fragrance of the delicate white flowers. The leaves are heart-shaped, bright glossy-green; growth is very rapid, often running 25 to 40 feet; quite hardy. Good roots, each $5 \mathrm{c}$., per doz. $50 \mathrm{c}$

\section{CLEMATIS PANICULATA}

\section{(Japanese Virgin's Bower.)}

This handsome hardy climber is one of the choicest and most satisfactory climbing flowering plants. Of strong, rapid growth, with small, dense, cheerful green foliage, and pure white, deliciously fragrant flowers which appear in the greatest profusion in August, and continue until late in the fall. The plant succeeds in almost any position; not only is it well adapted to run up all kinds of supports but is just as useful for planting among rockwork, sloping banks, covering graves, or, in fact, any position where a graceful vine is desired. (See cut.) Strong plants, each 15c., per doz. $\$ 1.50$, per $100 \$ 10.00$; extra strong plants, $25 \mathrm{c}$., per doz. $\$ 2.50$, per $100 \$ 15.00$.

\section{LARGE-FLOWERINC CLEMATIS}

The following is a select list of varieties that succeed best in our climate. Many failures in growing this type of Clematis are distinctly traceable to shallow planting and a disease to which they are subject. We are careful to send out only perfectly healthy stock, and cannot entertain any complaints on this class of plants.

Henryi. Creamy white, large.

Duehcss of Edinburgh. Double pure white.

Gypsy Queen. Rith purple.

Jackmanni. The popular rich purple variety.

Jaekmanni Superba. A deeper-flowered form of Jackmanni.

Ville de Lyon. Bright carmine, the nearest approach to a red yet introduced. (See cut.) Each $60 \mathrm{c}$.

Any of the above $40 \mathrm{c}$. each; $\$ 4.00$ per doz.

\section{HONEYSUCKLES}

Chinese Evergreen (Woodbine). Red, yellow and white rariegated flowers; very fragrant.

I.alliana. Flowers pure white, turning to yellow; fragrant, hardy evergreen; flowers freely.

Fraegated (Aurea Reticulata). Foliage beautifully mottled yellow and green: succeeds in any situation.

Price of the above strong plants, $25 \mathrm{c}$. each; $\$ 2.50$ per doz.

\section{HOP VINE}

(Fiumulus lupulus.)

Commen. One of the very best climbers for covering unsightly places. It is a rapid grower and bears a profusion of seed pods suitable for many domestic purposes. Each $5 \mathrm{c}$, per doz. $50 \mathrm{c}$.

Golden. A golden-leaved variety of the common Hop Vine, possessing the same strong climbing habit and hardiness, but with bright golden-vellow foliage; a most desirable hardy climber. Each 15 c., per doz. $\$ 1.50$.

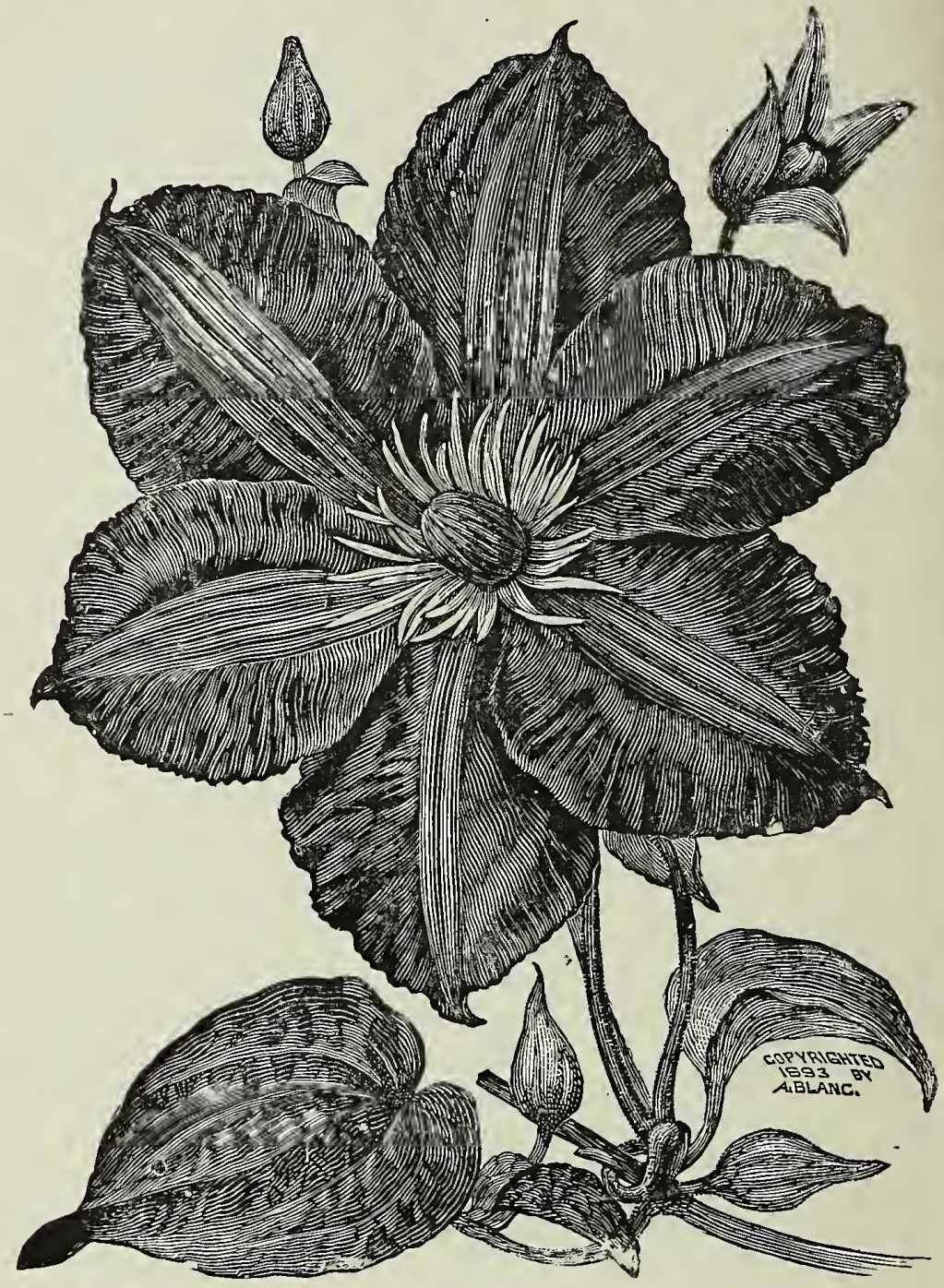

CLEM + TIS.

\section{MADEIRA OR MIGNONET 2 E VINE}

A rapid-growing vine, covering a large space in a short time. Fleshy heart-shaped leaves of a light green, and numerous racemes of feathery flowers of delicious fragrance. A beautiful and popular vine. Protect with litter in this latitude. Each 5c., per doz. 40c. by mail, 10c. per doz. extra.

\section{HARDY MOONFLOWER}

\section{(Ipomoea Pandurata.)}

This is one of the most rapid-growing vines. A root three or four years planted will send up a number of strong shoots that climb rapidly to a height of 30 or 40 feet. These shoots branch freely from the ground up, forming a perfect network of strong branches, densely covered with large deep-green, heart-shaped leaves, which overlap each other. forming a dense screen. The flowers, which are very large, are satiny-white, with a pinkishpurple throat, shading off deeper in the tube. Each 10c., per doz. $\$ 1.00$

\section{CHINESE WISTARIA}

One of the best of all hardy climbers. When given a sunny situaticn and liberal manuring it grows rapidly, and presents when in bloom a magnificent appearance.

Sinensis. The favorite variety, producing thousards of pendulous clusters of delicate violet blue blossoms, richly perfumed. Extra strong plants, each $50 \mathrm{c}$.

Alba. Of similar habit to Sinensis, with pure white flowers; a lovely climber. Each $50 \mathrm{c}$. 


\section{HIGH GRADE RELIABLE FERTILIZERS}

\section{Ashes}

These contain all of the fertilizing elements except nitrogen j lbs. 20c., 10 lbs. 35c. 25 lbs. 60c.. 50 lbs. S5c., 100 lbs. \$\$1.50. ton of $2.000 \mathrm{lbs}$. \$1S.00. Apply abont $1.000 \mathrm{lbs}$. to the acre.

\section{Bone Meal (Strictly Pure and Fresh)}

In fertilization nothing takes precedence in importance orer animal bones, because they furnish the soil with the essential requisite of nitrogen as mell as phosphoric acid. The most substantial fertilizer for lams and plants is Bone Meal. It keeps on feeding the soil for fully ten months. J-lb. Lag $25 \mathrm{c}$. $10 \mathrm{lbs}$. 40c., $25 \mathrm{lbs}$. 75c., $50 \mathrm{lbs}$. for $\$ 1.50,100 \mathrm{lbs}$. $\$ 2.50$, ton $\$ 30.00$.

\section{Blood (Dried)}

Vers rich in nitrogen. 5 lbs. 30c., 10 lbs. 50c., 2.5 lbs. $\$ 1.00$, 50 lbs. \$1.\$., $100 \mathrm{lbs} . \$ 3.50$

\section{Bowker's Plant Food}

Iade especially for plants growing in conservatory or house. Clean. free from offensire odor. Full directions with each package. Package 15̄c. and 25̌c., by mail 25̌c. and 40c.

\section{Lawn Dressing (Noll's Perlection Odorless)}

Verr rich in fertilizing ingrédients. Makes ronr lawn green, bright and dnrable. 5 lbs. for $25 \mathrm{c} .10 \mathrm{lbs} .40 \mathrm{c}$, 2.5 lbs. $\$ 1.00$, 50-lb. bag $\$ 1.50,100$ lbs. $\$ 2.50$, per ton $\$ 10.00$.

\section{Nitrate of Soda}

For all crops. Contains the largest percentage of nitrogen. equal to 19 per cent. of ammonia. It is rerr quick in action. and hastens maturity of crops fully two weeks. Should not be applied until the plants are above the ground, when 100 to $1.50 \mathrm{lbs}$. per acre should be sown with other fertilizers. or mixed with phosphates. I.b. 10c. . $1 \mathrm{bs} .30 \mathrm{c} .10 \mathrm{lhs}$. 50 ., 25 lbs. $\$ 1.00,50$ lbs.. \$2.00, 100 lbs. \$3.50, 200 lbs. \$6.25.

\section{Sheep Manure (Pure, Fresh Pulverized)}

One of the richest general fertilizers. Noll's $\Gamma \Gamma$ Brand, 5 lbs. 25c.. 10 lbs. 40c., 25 lbs. $\$ 1.00$, 50 lbs. $\$ 1.25,100$ lbs. $\$ 2.00$, ton $\$ 2 \$ .00$.

\section{Noll's Garden Fertilizer}

A specially prepared fertilizer for the garden, promoting a rapid and steady gromth. 5 lbs. 25c., $10 \mathrm{lbs}$. 40c., $25 \mathrm{lbs} . \$ 1.00$, 50 lbs. $\$ 1.50,100$ lbs. $\$ 2.50$, ton $\$ 45.00$.

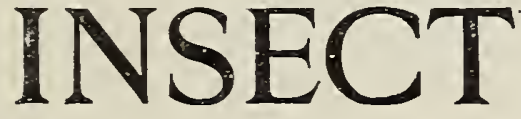

Aphis Punk. Box contains 12 double sheets. Price, 60c. pel box.

Bordeaux Mixture. Per lb. box 20c., 5 lbs. 75c. (makes 25 gallons spray). 10 lbs. $\$ 1.25$ (makes 50 gallons spray), 25 -lb, box. $\$ 2.50$ (makes 125 gallons).

Bordeaux Mixture. In liquid form. Per qt. 40 c., per gal. $\$ 1.00$.

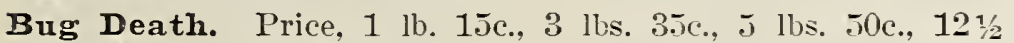
lbs. $\$ 1.00,100$ lbs. $\$ 7.00$.

Fir Tree Oil. 1/2-pt: 50c., pt. 75c., qt. \$1.50, 1/2-gal. \$2.75, gal. $\$ 5.00$.

Fir Tree Oil Soap. 1/2-lb. 25c., 2 lbs. 7ǰc.

Hellebore. For destroying rose slngs. Per lb. 2..j., 5 lbs. $\$ 1.00,10$ lbs. \$1.\$5.

IIoricum. A salt, sulphur and lime solution made by Hammond. For San José Scale. Per qt. 35c., per gal. \$1.00.

Kerosene Emulsion (Liquid). Per qt. 40c., per gal. \$1.00.

Lemon Oil. Will destroy mealy bug, scale. thrip, red spider, etc. Per 1/2-pt. 25c., per pt. 40c.. per qt. 75c., per 1/2-gal. $\$ 1.25$. per gal. $\$ 2.00$, 5-gal. keg $\$ 9.00$. Dilute 1 part of oil to 30 parts of water.

London Purple. Lb. 25̄c., 5 lbs. \$1.10. Special price on larger quantity.

Nikoteen. For spraying and raporizing. Per pt. $\$ 1.50$.

Paris Green (Pure). Lb. 30c., j lbs. \$1.40, 1t-lb. buckets $\$ 3.50$.

Tobacco Dust. Creaper than snuff and quite as effectual Sure remedy for green fly. Per lb. 10c., 5-lb. pkg. 25̄c., 100 lbs. \$3.j०.

\section{Kil-O-Scale The Great San Jose Scale Exterminator}

Directioxs: Kil-o-Scale is a concentrated liquid and is shipped in barrels. kegs and cans.

To 1 gallon of Kil-o-Scale add 20 to 25 gallons of cold water and stir. It is then ready to be applied to the trees.

If a second application is desired, dilute 1 gallon of Kil-oScale with 25 gallons of water.

Price: One gallon. $\$ 1.50$; five or ten gallons, \$1.25 per gal. Special price in barrels.

\section{Trade STERLINGWORTH Name \\ Whale Oil Soap and Tobacco}

Sterlingworth UJhale Oil Soap and Tobacco is a most

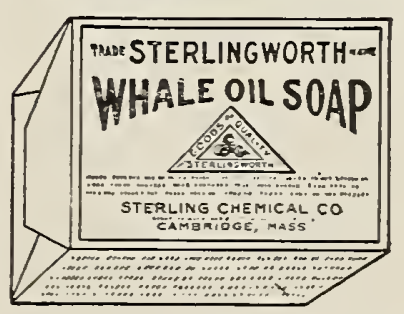
effectire reliable. simple and cheap preparation for destroying San José Scale. Plant Lice and all sncking insects on trees, shrubs, plants, vines. lose bnshes, etc. The efficiency of this soap is further increased by the addition of tobacco estractive matter and potash. The preparation thus compounded possesses all the rirtues of Thale Oil Soap and in addition. the raluable insecticide properties of tobacco and potash, making it donbly raluable.

Fnll directions for use on each package.

Prices: 1-lb. box 1ăc., 5-lb. bos 50c., 10-lb. bos. 90c. 


\section{INSECT DESTROYERS-Continued}

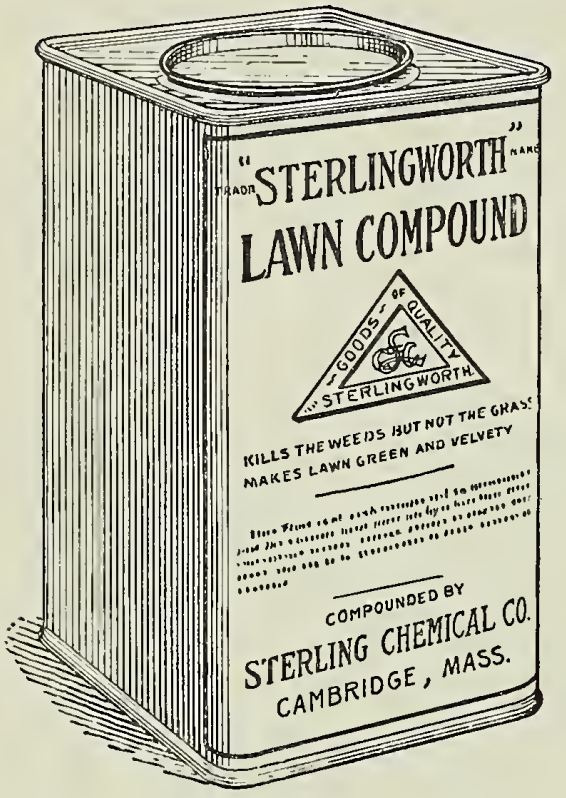

covers three to four square vards.

\section{Trade STERLINGWORTH Name LAWN COMPOUND}

Kills the weeds but not the grass and makes the lawn green and velvety.

Several years ago one of our leading seedsmen exclaimed to a salesman who was trying to sell him a bogus article for killing weeds in lawns, "Young man, do you mean to tell me that I can fire a shot-gun into a crowd and kill all my enemies and not injure my friends?" While it seems incredibie that a preparation can be made which will kill the weeds in lawns without injuring the grass, this is exactly what "Sterlingworth Lawn Compound" will do and also it will help the grass to grow green and greatly improve the sward. It absoJutely destroys Dandelions, Plantain, Chickweed, Crab Grass, and all weeds with hairy surfaces or broad leaves.

It is a dry sandy powder to be applied by sprinkling over the grass and is an achievement in modern chemistry of which the maker's are justly proud. One pound will dress 100 to 200 square feet depending on the condition of the lawn. Full directions for use on each package. Prices: 5-1b. cans, 60c.; 10-1b. cans, $\$ 1.00 ; 50$-lb. kegs, $\$ 4.00 ; 100-1 b$. kegs, $\$ 7.50$.

\section{Trade STERLINGWORTH Name WEED KILLER}

Sterlingworth Weed Killer is a most satisfactory and powerful Weed Killer, compounded especially for use on walks, drives, tennis courts, golf links, etc., etc. It is a dry powder to be dissolved in water. When applied to vegetation it completely destroys all kinds of weeds, grass (including milk weed and witch grass), Briars, Burdock, Dandelions, Daisies, Thistles, Poison Ivy and other objectionable vegetable growths. One application kills roots, as well as foliage, preventing further growtl. It may be applied with an ordinary watering can. One gallon

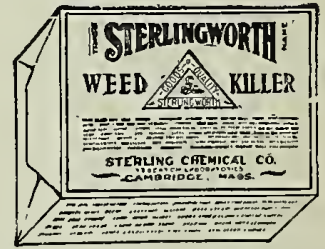

Full directions on each package. Prices: 1-lb. package makes 10 to 15 gallons, cover's 45 to 60 square yards, 50c.; 3-1b. package makes 30 to 45 gallons, covers 130 to 180 snuare yards, $\$ 1.25 ; 5$-1b. package makes 50 to 100 gallons, covers 300 to 400 square yards, $\$ 2.00$.

\section{TOOLS AND I MP LEM ENTS \\ FOR THE GARDEN, FARM, LAWN AND GREENHOUSE}

Owing to the many changes in prices during the past few seasons we have decided not to affix prices and would respectfully request customers to write us their wants, when we will promptly send full descriptions and current prices.

Asparagus Buncher.

Asparagus Knife.

Asparagus Ties.

Axes.

Bill Hooks.

Border Knife.

Brooms.

Brush Axe.

Caponizing Tools.

Corn Husker.

Corn Break, The Eureka.

Corn Knives, Eureka.

Dibbles, Round.

Floral Tools.

Forks-

Digging or Spading.

Manure Forks.

Manure Forks "Extra Heavy."

Hay Forks.

Potato Digging Forks.

Vegetable Scoop Forks.

Wooden Stable Forks.

Stone Picking Forks.

H a n d $W$ e d ing or Transplanting.

Fruit Picker.

Garden Lines.

Garden Line Reels.

Glazing Points, Perfection.

Glazing Putty, Twemlow's Old English

Grafting Wax, Trowbridge's.
Grass Hooks, Common Adjustable.

Hay Knives.

Hatchets-Axe Pattern.

Hedge Knife.

Hose-"Standard Q u a 1 ity."

Hose Menders, Cooper's.

Hose Nozzle.

Hose Nozzle, Graduating.

Hose Nozzle, Bordeaux.

Hoes-Draw or Field. Warren Heart-Shaped Hoes.

Acme Weeding and Cultivating Hoe. Double Prong.

Acme Weeding and Cul. tivating Hoe. Single Prong.

English Scuffle or Push Hoes.

Grub Hoe.

Prong Hoes or Potato Hooks.

Burlap Mats.

Size A.

Size $B$.

Labels, Wooden.

Labels, Garden.

Labels, Pot.

Labels, Wired.

Lawn" Edger, "Planet Jr."
Lawn Mowers-

Lawn Sprinklers. Water Witch.

Mole Trap, Reddick's.

Picks, Clay or Railroa교. Pick Mattock.

Axe Mattock.

Plant Supports.

Pruners, Water's Tree.

Rakes, Lawn, Wooden. Automatic Self-Cleaning Lawn Rake.

Reversible Steel Lawn Rake.

Steel Garden Rakes.

Fine-Tooth Gravel Rakes, Steel.

Rakes, Steel "Bow" Garden Rake.

Wooden Hay Rakes.

Raphia, for tying.

Cast-Iron Hand Rollers.

Rubber Plant Sprinklers.

Straightneck.

Angleneck.

Rubber Putty Bulb.

Saws-Pruning, Doubleedge.

One-edged Pruning.

California Bow-shaped.

Iittle Giant Pruning Hook and Saw Combined.
Scythes - Lawn English Riveted Back.

Hollow Clipper Grass Scythes.

Bush Scythe.

Scythe Snaths or Handles.

Scythe Stones. Imported English Talacre.

Shears, Hedge.

Lawn Shears.

Grass Edging or Border Shears.

Shovels.

Square.

Round Point.

Scoop Shovels.

Wire, Potato and Root Scoop.

Boys' Shovels and Boys' Spades.

Spades.

Stcel.

Tubs for Palms and Trees.

Tomato Supports.

Tree Scraper.

Trowels-Ordinary.

Solid Steel.

"Slim Jim" Trowel.

Watering Pots.

Wotherspoon's Galvanized Watering Pots.

Weeders.

Weed Cutter. 


\section{POULTRY
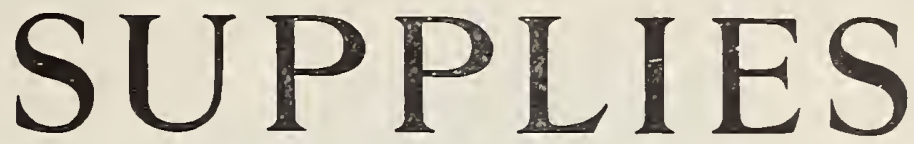

We carry a full line of poultry requisites. Cyphers Incubators and Brooders, Chick Food, Bird Seeds, Drinking Fountains, Feeding Troughs, etc. Below is a list of what we carry.

ANIMAL MEAL (BOWKER'S). 10-lb. bag 50c, 25-1b. bag $\$ 1.00$, 50 -lb. bag $\$ 1.50,100$-lb. bag $\$ 2.50$.

BEEF SCRAPS. Fure. 5 lbs. 25c., 10 lbs. 40c., $25 \mathrm{lbs}$. 95̄c., 50 lbs. $\$ 1.05,100$ lbs. $\$ 2.90$.

BIRD GRA VEL. Pkg. כ̌.

BIRD MANNA. 15̄c. each.

BONE. Coarse. 5 lbs. 25c., 10 lbs. 40c., 25 lbs. 75 c., 50 lbs $\$ 1.50,100$ lbs. $\$ 2.50$.

BONE MEAL. 5 lbs. 25c., 10 lbs. 40c., 25 lbs. 75 c., 50 lbs. $\$ 1.50,100$ lbs. $\$ 2.50$.

CHARCOAL. Coarse and fine. 10c. per pkg., 5 lbs. 25c., 10 lbs. 40c., 25 lbs. 75 c., 100 lbs. \$2.50.

CANARY. Pure. 10c. per lb., $100 \mathrm{lbs}$ \$7.00.

CLOVER HAY. Price on application.

CLOVER MEAL. Price on application.

CLOVER SHREDDED. Price on application.

CYPHERS DRY FOOD HOPPERS. Tٓ. each.

CYPHERS EGG TESTER. 25c. each.

CYPHERS FULL NEST EGG FOOD. Pkg. $2 \bar{c}$.

CYPHERS GRIT AND SHELL BOXES. 50c. each.

CYPHERS LIQUID LICE PAINT. 35c.. 60c. and $\$ 1.00$.

CYPHERS NAPCREOL DISINFECTANT. 50c., S5̄c. and $\$ 1.50$.

CYPHERS POULTRY REMEDIES. Ten different kinds. 25c. each.

CYPHERS PRACTICAI EGG TESTER. \$1.2J.

CYPHERS SAFETY BROODER STOVE. \$1.75 each.

DIAMOND MESH POULTRY NETTING. Lowest market prices.

DRY FOOD HOPPERS. 75c. each.

EARTHEN PIGEON NESTS. Sc. each, 75c. per doz.

FLAX SEED (Whole). Lb. 10c.. 5 lbs. 35̄c., 10 lbs. 60c., 25 lbs. $\$ 1.35$, 50 lbs. $\$ 2.50,100$ lbs. $\$ 4.50$.

FLAX SEED (Ground). Same price as whole flax.

GALVANIZED WALL FOUNTAINS. Cyphers Patent, 50c. and $\$ 1.00$. Cyphers Round Patent, 1 c., 25c., 3๊c. Duck size. $50 \mathrm{c}$.

GAPE WORM EXTRACTORS. 25c. each.

GRIT AND SHELI BOXES. 50c. each.

HALLOCK'S FOOD AND WATER PANS. T5c., $\$ 1.00$ and $\$ 1.25$.

HEMP. Good nlump seed. T.b. 10c.. 5 lbs. 35̄c., 10 lbs. 50c., 25 lbs. $\$ 1.10,50$ lbs. $\$ 1.90,100$ lbs. $\$ 3.50$.

IDEAL ALUMINUM LEG-BANDS. 15c. per doz., 75c. per 100.

IICE KILLING NEST EGGS. 7c. each. 75c. per doz.

MANN'S BONE CUTTERS. Different sizes, from $\$ 6.00$ up to $\$ 100.00$.

MANN'S CLOVER CUTTER. Complete. $\$ 10.00$.

MICA GRIT. Coarse, medium and fine. 5 lbs. 15c., $10 \mathrm{lbs}$. $25 \mathrm{c} ., 25 \mathrm{lbs}$. $35 \mathrm{c}$. 100 lbs. $\$ 1.00$.

MILLET. Lb. 10 c., 100 lbs. $\$ 5.00$.

MIXED BIRD SEED. Ib. 10c., 5 lbs. 40c., 25 lbs. \$1.75, 50 lbs. $\$ 3.00,100$ lbs. $\$ 6.00$.
NOIL'S EGG FOOD. Pkg. 2.je.

NOLL'S IICE POWDER. 25. and 50c.

NOLL'S IIQUID LICE KIILER. Qt. 35̄c., 2 qts. 60c., 4 qts. $\$ 1.00$.

OYSTER SHELLS. Coarse and fine. 5-lb. pkg. 10c., $25 \mathrm{lbs}$. $25 \mathrm{c} ., 50 \mathrm{lbs} .45 \mathrm{c} . .100 \mathrm{lbs} .85 \mathrm{c}$.

PAPER EGG BOXES. S5̄. per 100.

PEAS. For pigeons. 5 lbs. $30 \mathrm{c}, 10 \mathrm{lbs} .50 \mathrm{c}, 25 \mathrm{lbs} . \$ 1.00$, 50 lbs. $\$ 1 . \$ 0.100$ lbs. $\$ 3.50$.

PRATT'S LIQUID IICE KILLER. Qt. 35c., 1/2 gal. 60c., gal. $\$ 1.00$

PRATT'S POULTRY FOOD. 10c., 25c., 60c., $\$ 1.25$ and $\$ 2.50$.

PORCELAIN NEST EGGS. 25c. per doz.

POULTRY DRINKING FOUNTAINS (Stone). Qt. 25c., 2 qts. 40 c., 4 qts. $50 \mathrm{c}$., 2 gal. $75 \mathrm{c}$.

POULTRY KILLING KINIVES. 50c. each.

POULTRY NETTING. All sizes, 2-in. mesh and 1-in. mesh. Price upon application.

RAPE. Lb. 10c., 5 lbs. 40c., 25 lbs. $\$ 1.75,50$ lbs. $\$ 3.00,100$ lbs. $\$ 6.00$.

RICE. Whole. 5 lbs. 40c., 10 lbs. 70c., 25 lbs. $\$ 1.50,50$ lbs. $\$ 2.75,100$ lbs. $\$ 5.00$.

ROOFING MATERIAL. REX FLINTKOTE. 1/2-ply. $\$ 1.75,1-p l y \$ 2.25,2$-ply $\$ 3.25$. This price for single rolls, Double rolls, double price.

ROUP CURES. Rust's Soluble, 25̄c. Conkey's, 25̄c., $50 \mathrm{c}$. and $\$ 1.00$. Cyphers, $25 \mathrm{c}$., 50c. and $\$ 1.00$. Rust's Roup Pills, 25c., 50c. and $\$ 1.00$.

RUST'S EGG PRODUCER. 25c., 50c. and $\$ 1.00$.

RUST'S HAVENS CONDITION POWDER. 2うc., 50c. and $\$ 1.00$

RUST'S LICE POWDER. 25c., 50c. and $\$ 1.00$.

RUST'S IIQUID LICE KILLER. Qt. $355 \mathrm{c}$, 1/2 gal. 60c., gal. $\$ 1.00$.

RUTHERFORD RED ROPE ROOFING. $100 \mathrm{sq.} \mathrm{ft.}$ $\$ 1.25,250$ sq. ft. $\$ 2.50,500$ sq. ft. $\$ 5.00$.

SPRATT'S CHICK FOOD. Same price as Poultry Food.

SPRATT'S POULTRY FOOD. $5 \mathrm{lbs} .40 \mathrm{c} ., 10 \mathrm{lbs} .70 \mathrm{c}$. 25 Ibs. $\$ 1.75,50$ lbs. $\$ 3.00,100$ lbs. $\$ 5.00$.

SPRAYERS. Automatic, or Compressed Air Sprarcrs. Price upon application.

MYERS' BUCKET SPRAY. With Bordeaux nozzle. $\$ 4.50$. With ordinary nozzle, $\$ 3.50$.

STANDARD SPRAY. Guaranteed for five jears. Complete. $\$ 5.50$.

TIN SPRAYERS. For disinfecting, 50c. and $75 \mathrm{c}$.

SULPHUR FUMIGATING CANDLES. 15c. each, $\$ 1.00$ per doz.

SUNFLOWER. Ib. 10c., 5 lbs. 40c., 25 lbs. \$1.75, 50 lbs. $\$ 3.00,100$ Ibs. $\$ 5.50$.

THERMOMETERS. For incubators and brooders, 50c. and 60 c. each.

WILSON DRY BONE AND SHELL MILL. $\$ 5.00$ and $\$ 7.00$.

WIRE NESTS. 15c. each. $\$ 1.50$ per doz. 


\section{POULTRY SUPPLIES-Continued}

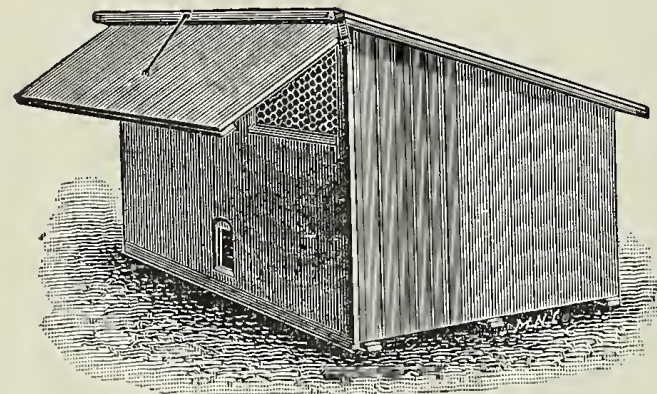

\section{CYPHERS COLONY HOUSE FOR GROWING CHICKENS}

This Colony House, or Roost Coop, will house comfortably fifty chicks, eight to twelve weeks oll. 'The hinged hood keeps out rain and snow and can be used as an awning. 'The floor is removable. Our price is considerably lower than the cost of building them singly or in small numbers. Dimensions: Floor space, $3 \times 6 \mathrm{ft}$. Height in front, 36 in. Height at rear, 24 in. Painted in green, with red trimmings.

Price, complete

.\$S 00

\section{CYPHERS INCUBATORS AND BROODERS}

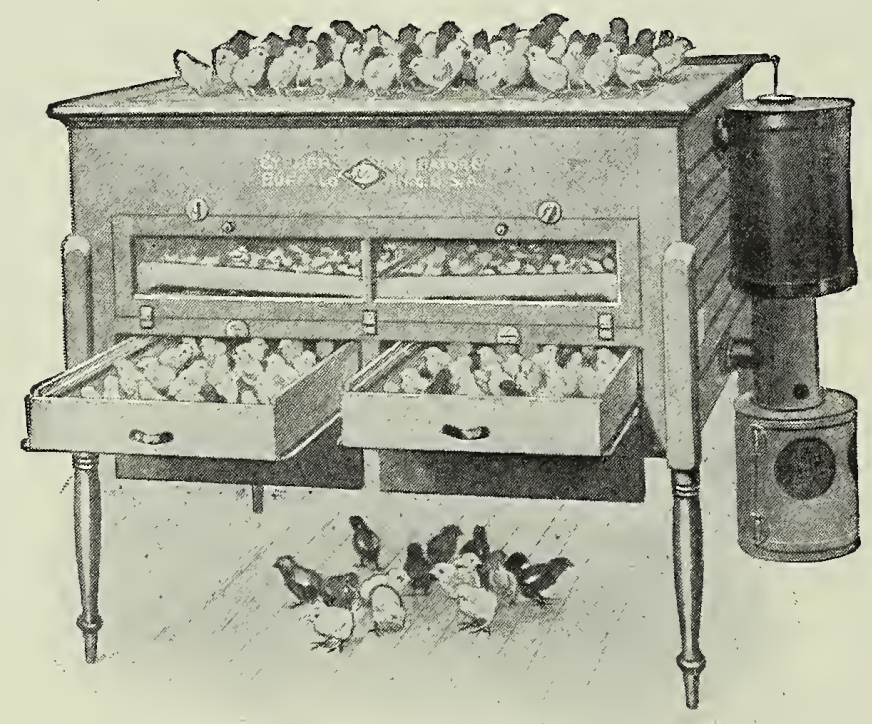

\section{CYPHERS INSURABLE INCUBATORS}

The first incubator to be built that is approved by representatives of the National Board of Fire Underwriters. 'This means that you can run an incubator without any fear of a fire or having to pay extra insurance, or having your policy cancelled. Those who have refrained from this pleasure can rest assured that they may do so without any interference on the part of insurance companies. There are a few things of interest to prospective buyers of incubators and we will be only too glad to give any information desired. The prices of 1909 Cyphers Standard Incubators are: No. $0 \$ 15.00$, No. $1 \$ 22.00$,

No. $2 \$ 32.00$, No. $3 \$ 38.00$.

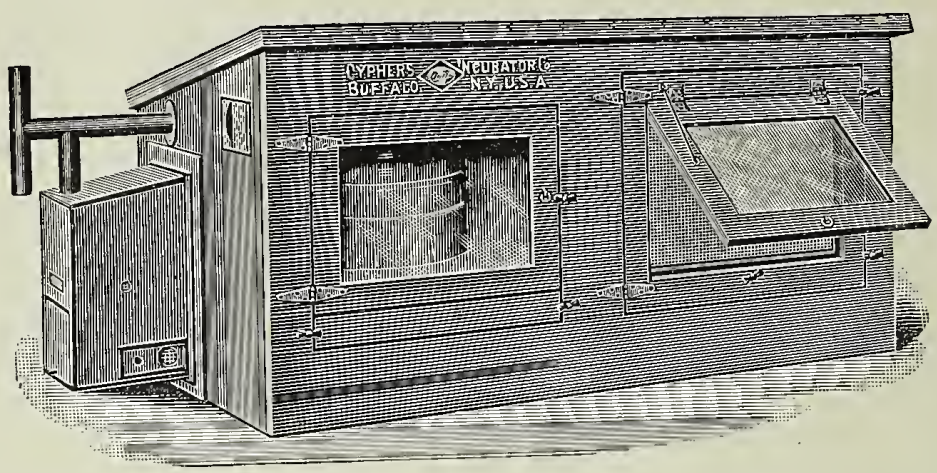

\section{CYPHERS 1909 BROODERS}

Comply fully and satisfactorily with the necessary fire protection requirements, same as the 1009 Incubators. 'This Brooder has to be seen to be convinced of its merits. The prices for 1909 styles are as follows:

Style A 1909 Brooder .................... \$12.50

Sityle B 1909 Brooder ................... 16.50

Style C 1909 Brooder .................... 18.50

Style D 1909 Brooder ..................... 11.50

\section{CYPHERS NEW MODEL COOP FOR HEN WITH CHICKS}

Price, complete

.$\$ 350$

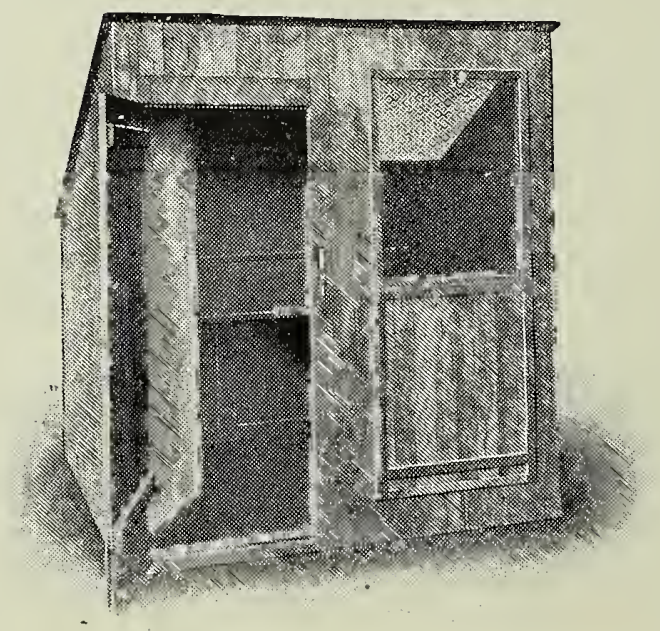

\section{CYPHERS SHED-ROOF CANVAS LIGHTED HOUSE}

This house possesses all the advantages of both closed and curtain-front poultry buildings. Waterproof paraffined sheeting being used instead of glass, all danger of broken windows when moving is eliminated. In addition to ordinary wooden door there is an inside door made of waterproof sheeting. This sheeting freely admits light, but keeps out wind and rain. Dimensions: Floor space, $6 \times 5 \mathrm{ft}, 10 \mathrm{in}$. Height in front, $6 \mathrm{ft}$., $10 \mathrm{in}$. Height in rear, $4 \mathrm{ft}$. Window, $2 \mathrm{ft}$., 7 in. $x 2 \mathrm{ft}$. Price, complete, F. O. B. factory, Buffalo, N. Y., $\$ 20.00$. 


\section{"Iron Age" Farm and Garden Implements}

As spaee permits showing only a few of these valuable tools, a complete deseriptive "Iron Age" Catalogue will be sent

The No. 6 "Iron Age" Combined Double and Single Wheel Hoe, Hill and Drill Seeder

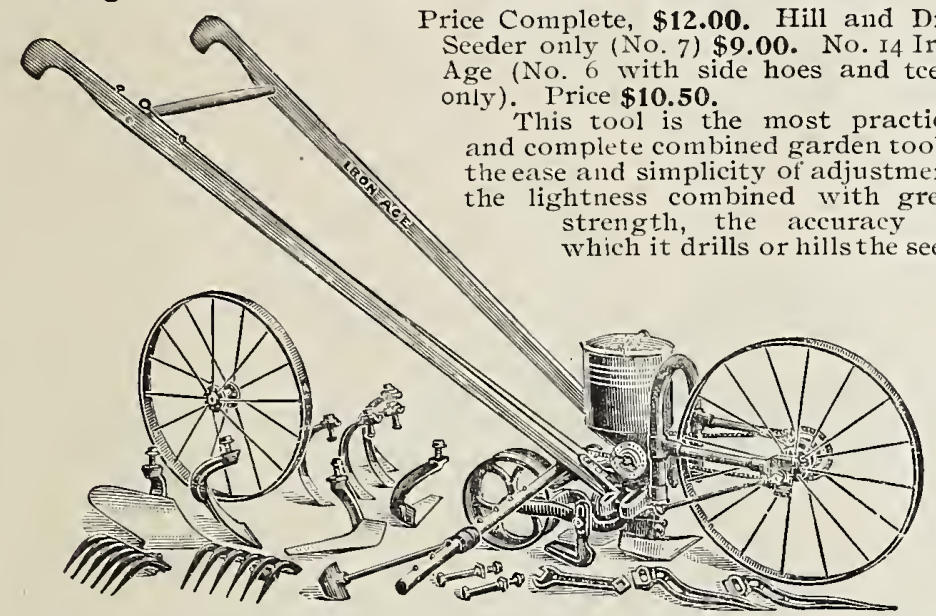

and the small amount of power required to operate it are important features. In each form, whether a Seed Drill, a Double Wheel Hoe, a Single Wheel Hoe or any of the wheel hoe forms, it is equal to any tool or tools made especially for the one purpose. It places he seeds ino. I opposite.

No. 15 "Iron Age" Combined Single Wheel

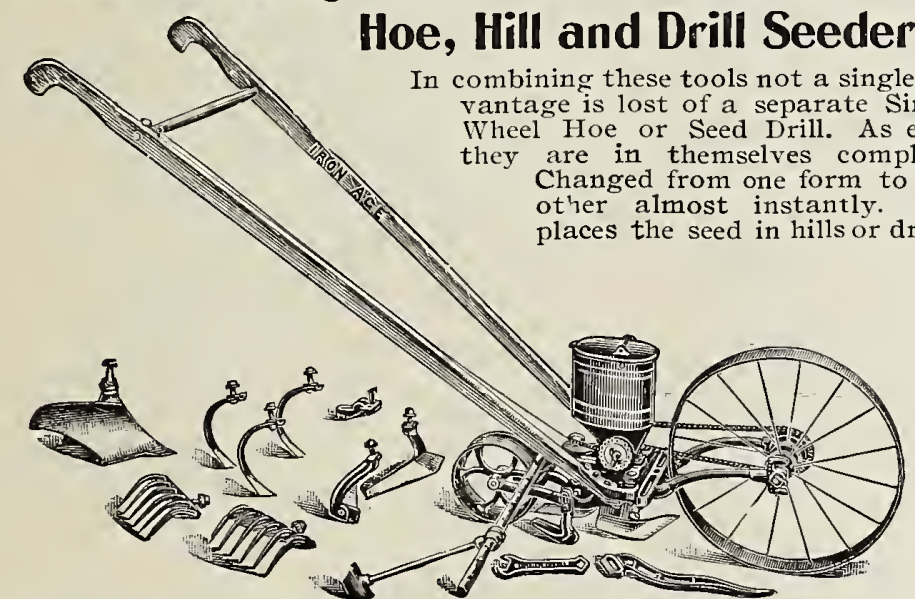

A landside plow; side hoes, cultivator teeth and rakes are furnished. Price, complete, $\$ 11.00$. No. Í́ (No. I5 as a seeder only). Price $\$ 8.50$.

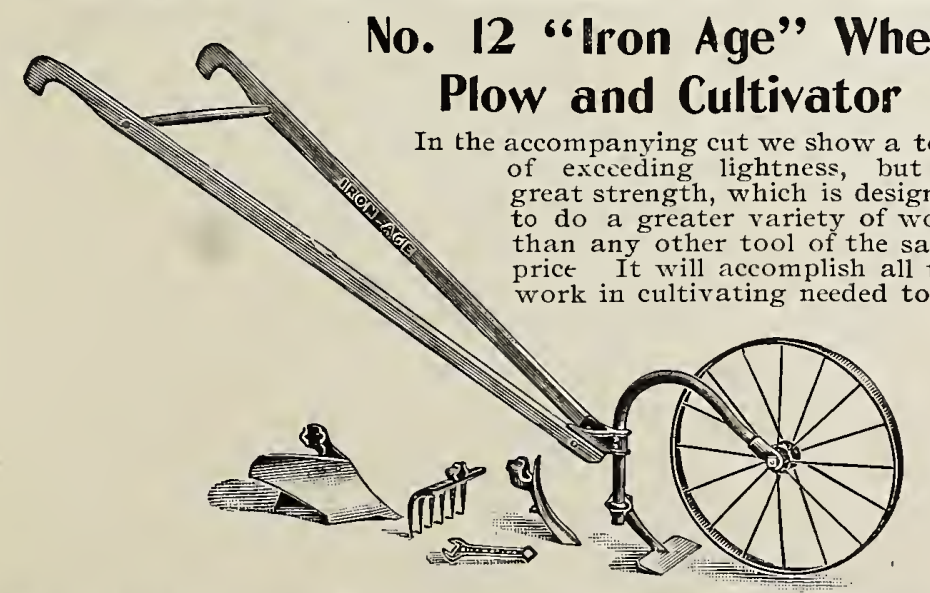

done in a small kitchen garden, plowing, furrowing, covering, hoeing, raking and cultivating. Price, complete, $\$ \mathbf{3 . 5 0}$.
No.I "Iron Age"' Double and Single Wheel Hoe

Price complete, \$7.00. No 3 Double Wheel Hoe (Side hoes only) \$4.25.

This is the Wheel Hoe form of the No. 6 opposite. One great advantage which this Double Wheel Hoe possesses is that it can be made into a practical is that it can be made into a practical As a Double Wheel Hoe it may be used As a Double Wheel Hoe it may be usc
astride the row and thus cultivatc both sides of the row at the same

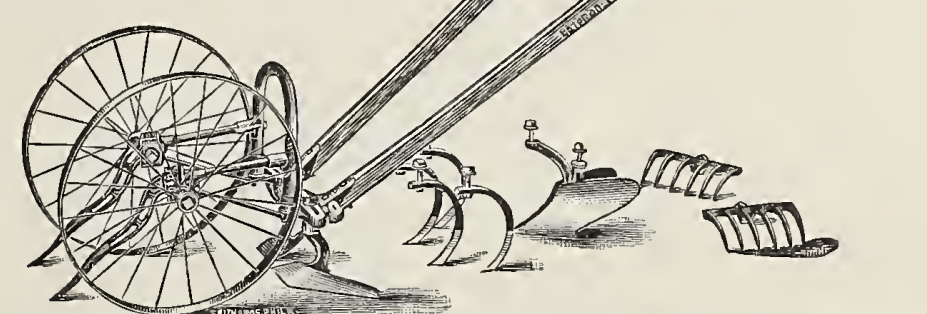

time. The wheels are 16 inches high, enabling the wheel Hoe to run easily and without yielding to the inequalities of the soil as a low wheel will do. The frame being made of pipe coupled with malleable castings, gives great strength, together with lightness. Mav be quickly changed from a hoe to a cultivator, plow or rake. A Seeder attachment may be applied for sow-
ing in drills only, or sowing buth in drills and hills. Price $\$ 4.00$ and $\$ 5.00$ respectively.

\section{No. 18 "Iron Age" Drill Seeder}

places the seed in continuous rows, and is a very low price drill. Price $\$ \mathbf{7 . 5 0}$

No. I7 (this Seeder with side hoes, cultivator teeth, andside plow and rakes). Price $\$ 10.00$.

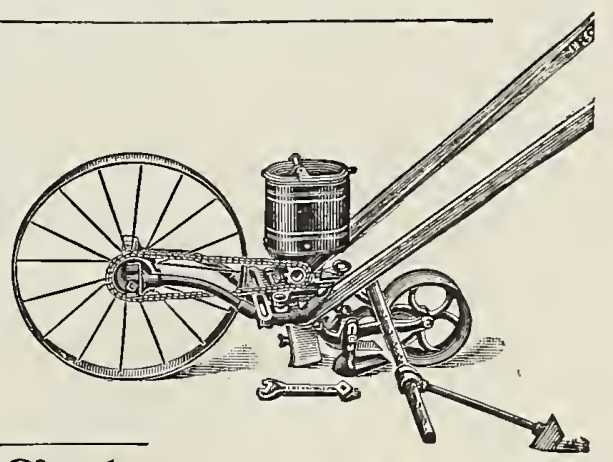

\section{No. 20 "Iron Age"' Single} Wheel Hoe. Price complete, No. 21, Plain (Hoes only). $\$$ Price $\$ 4.00$. The frame of this tool, as all the "Iron Age" combined tools is made of pipe coupled to malleable castings, thus rendering them

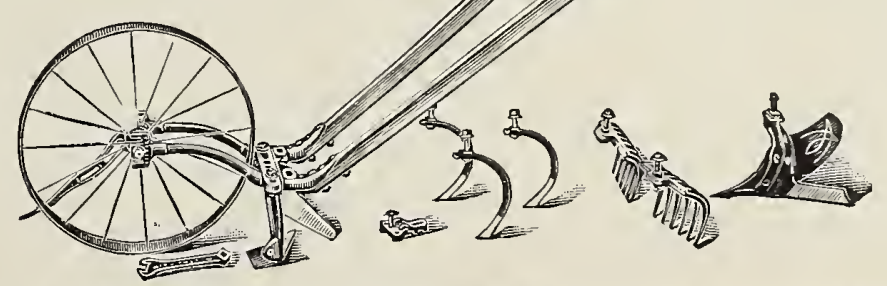

light and strong. A pair of side hoes, a set of cultivator teeth, a pair of rakes and a landside plow are furnished with this tool. As with a NC. I, a seeder attachment may be added at any time.

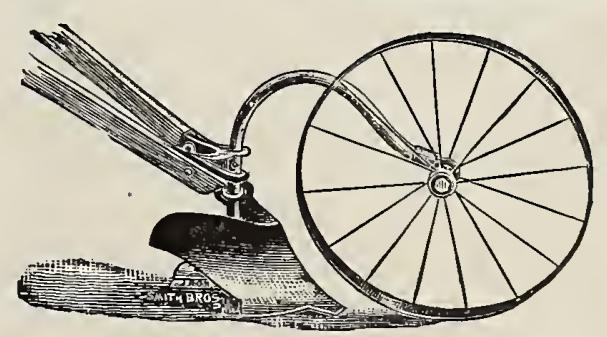

No. II "Iron Age" Wheel Plow

This is the plow form of No. 12 opposite. It will plow from three to four inches deep and throw a furrow four to six inches wide. Will open or cover the furrows for manure and seed. It is very light an Price, \$2.50. 
115 Mulberry St., Newark, N. J.

\section{"Iron Age" Farm and Garden Implements}

As space permits showing only a few of these valuable tools, a complete descriptive "Iron Age" Catalogue will be sent

free on request.

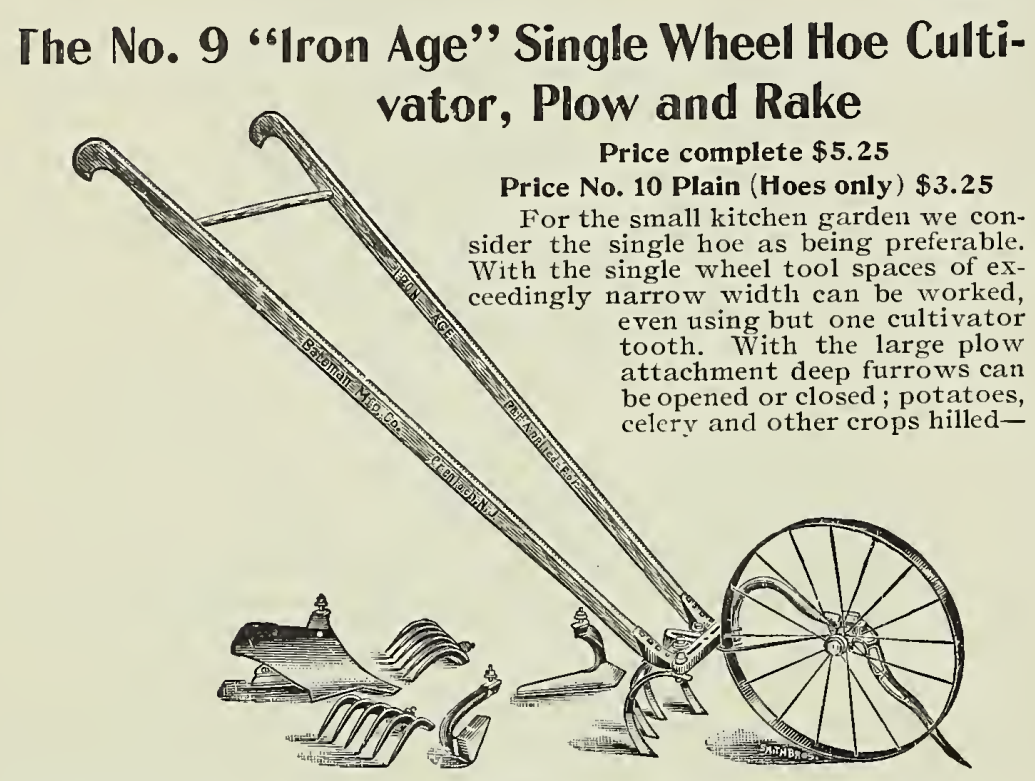

in short, all work usually accomplished by a special plow. It is light and runs easily.

No. I "Iron Age" Combined Harrow and

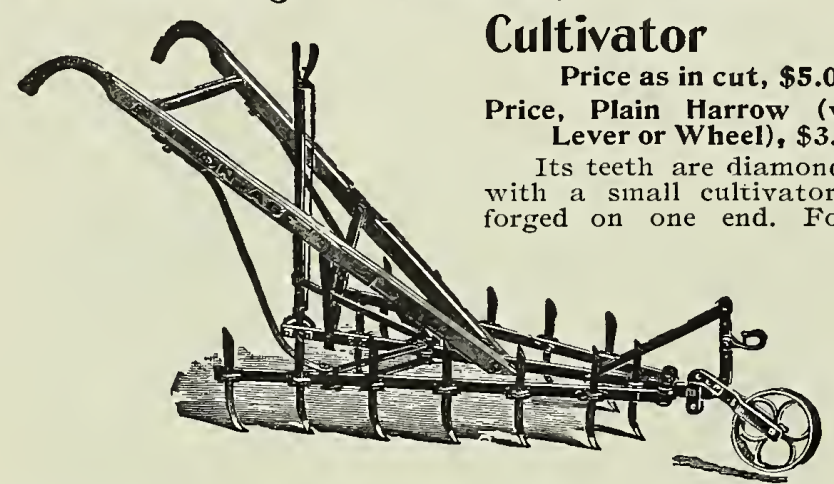

close work every other tooth can be quickly removed. This tool is designed esnecially for the cultivation of berries and small crops, as it thoroughly pulverizes the soil, but at the same time throws very little earth.

\section{The "Iron Age" (Improved Robbins) Potato Planter}

Price with Fertilizer Distributor, $\$ 80.00$ Without Fertilizer Distributor, $\$ 70.00$ Corn, Bean and Pea Attachment, $\$ 5.00$

The only perfect planter made. Plants 100 per cent. of the seed

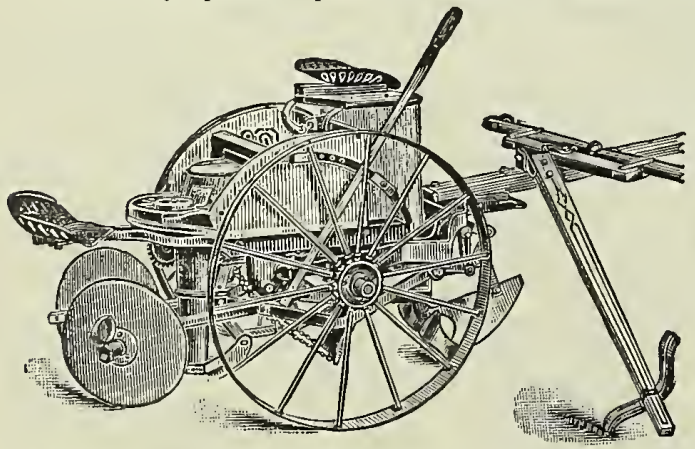
correctly. No misses or doubles and does not puncture or injure the seed. Does better work than planting by hand. It marks out the row, opens the furrow; distributes the fertilizer in a broad strea $\mathrm{m}$, thoroughly mixed with the soil below and not in contact with the seed; places the seed at regplaces the seed at reg desired; and covers with a full free covering. Does the work of several men in one operation, planting from 4 to 7 acres per day.

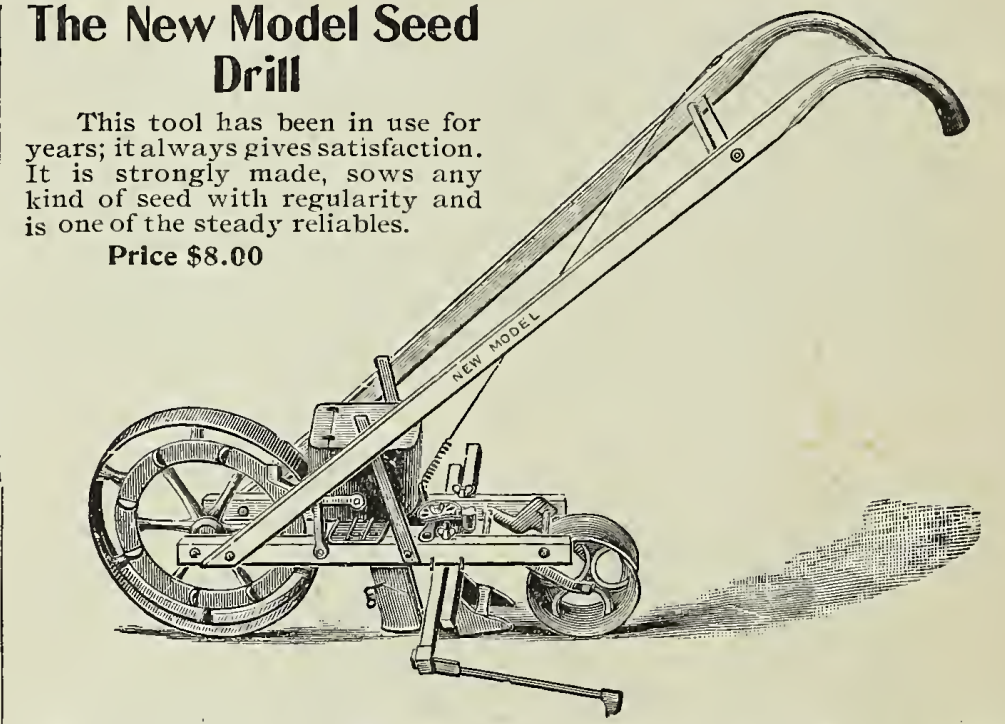

No. 6 "Iron Age" Horse Hoe and Cultivator

Price as in cut, $\$ 6.25$

With Plain Wheel and without

Lever Expander, Price \$5.00

This is truly a 2otn century tool. It is a popular implement wherever the sun shines and the crops grow. Its great adjustability adapts it for numberless uses and conditions.

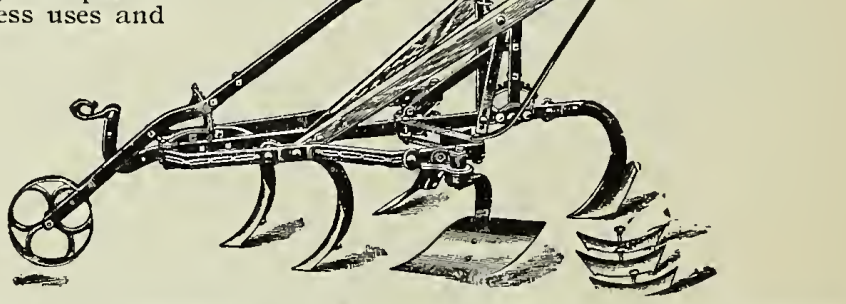

No. 82 "Iron Age" Pivot Wheel, Riding Cultivator $\begin{gathered}\text { Price } \\ \$ 32.00\end{gathered}$

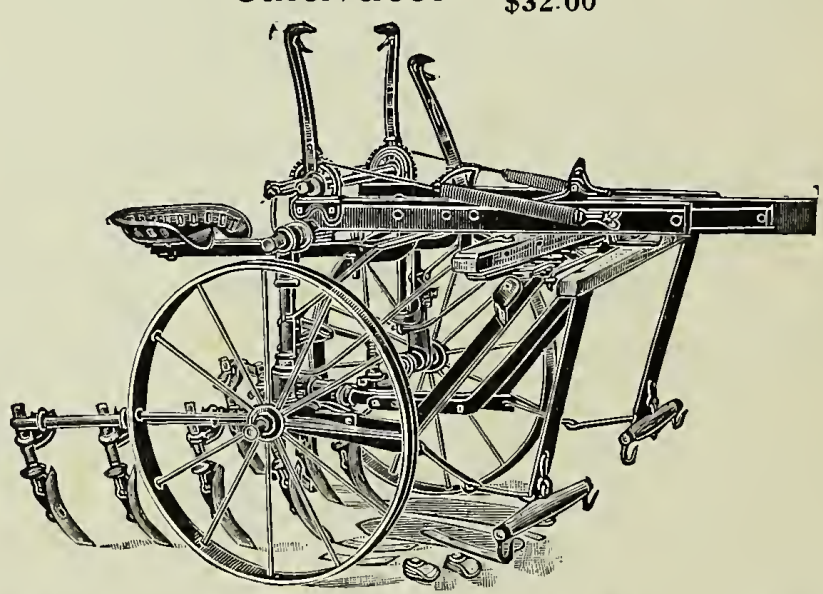

This Riding Cultivator is claimed to be the most up-to-date and satisfactory cultivator made. The Wheels are pivoted, the whole weight of the tool resting upon hardened steel balls and the pivots being very close to the center of the wheels it can be very easily guided, rendering it adapted for cultivating on hillsides; or economizing space at the end of rows. The wheels can be easily fixed in position, by simply dropping a pin in the hole, for the working fixed in position, by simply dropping a pin the the for the working of the cultivator in fallow ground and for drawing it $t$ faced tire and are adjustable in width. Various attachments may be ap plied to this tool; as fallow tooth; Double Row Extensions, Plows. Dises
and Spring Hoes. 


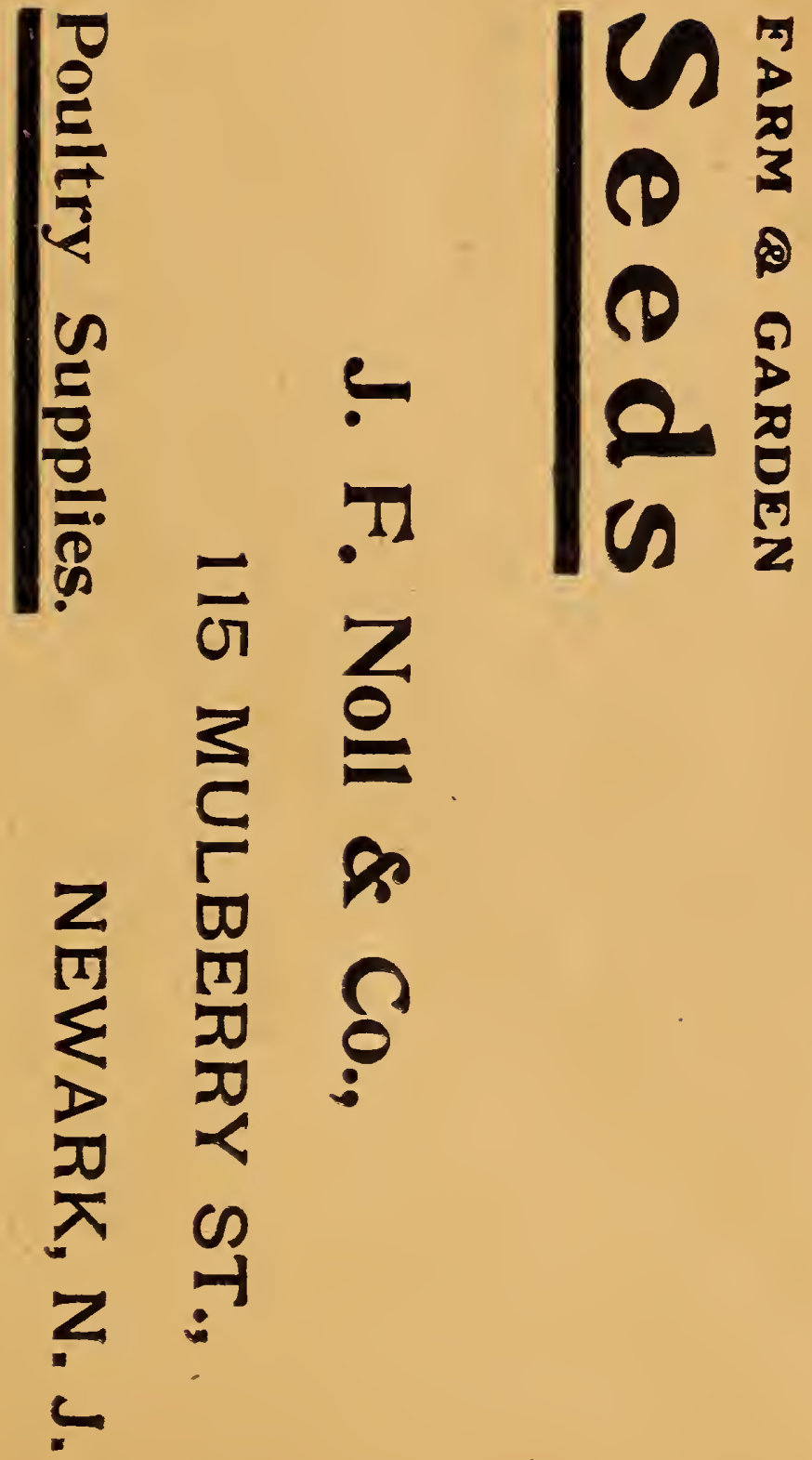




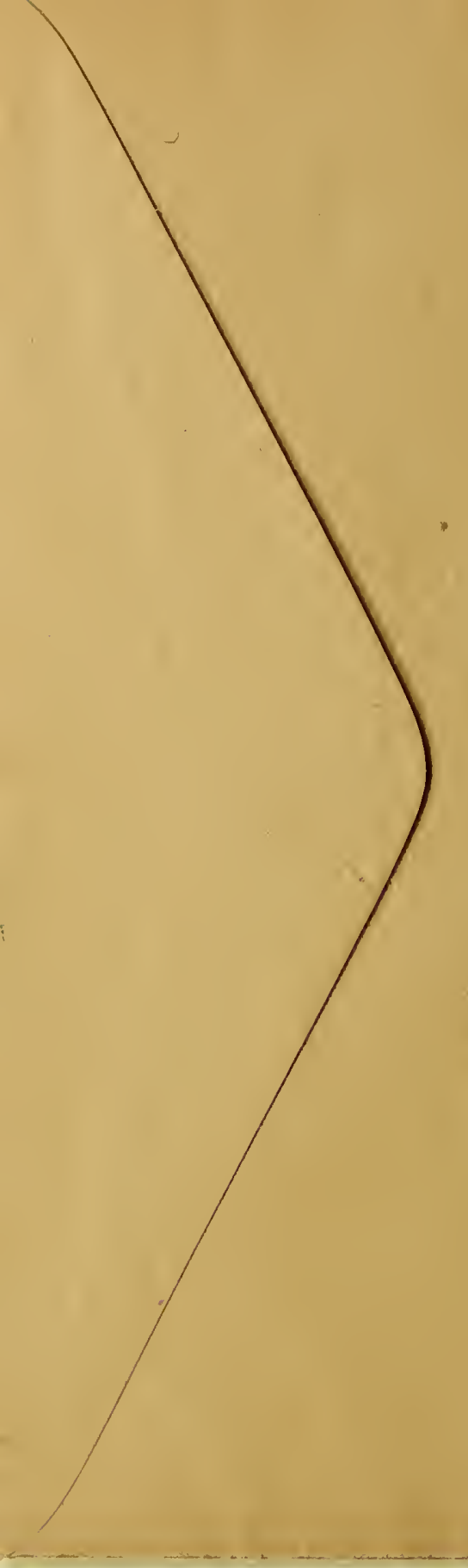



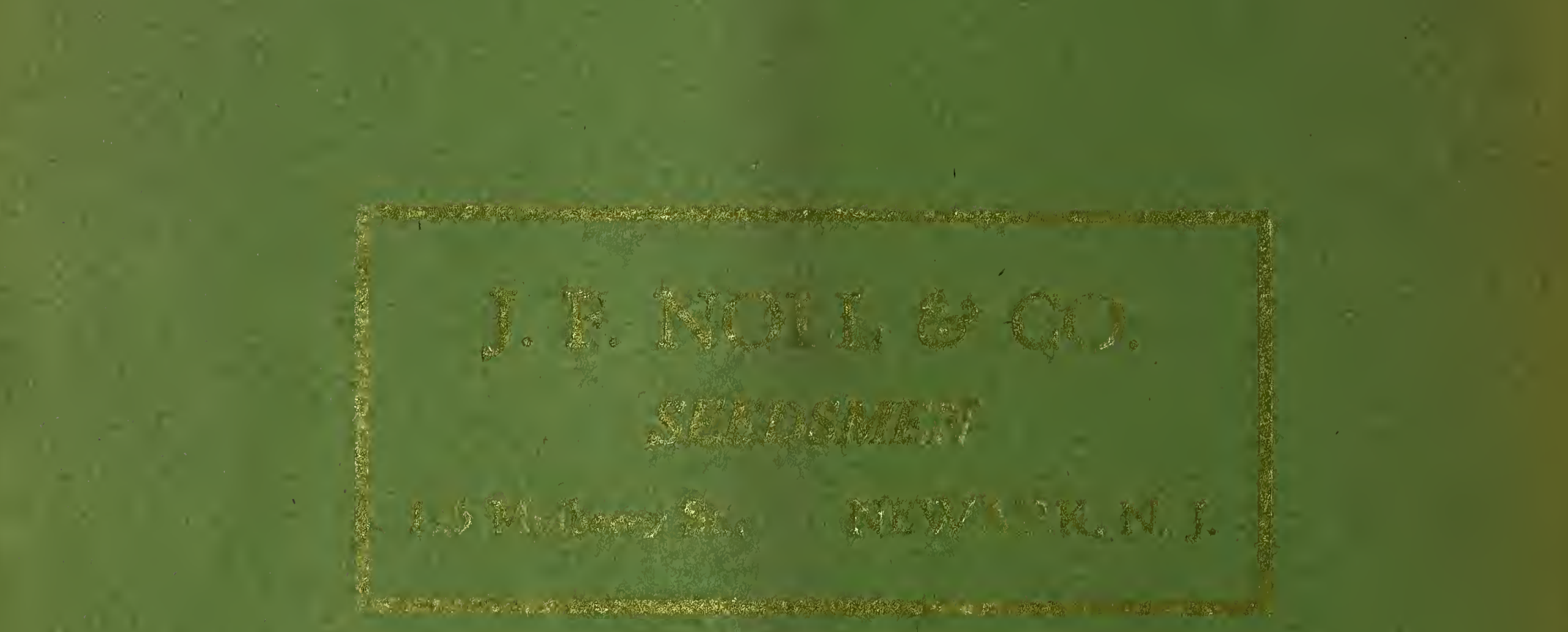